PFBC HGCU Test Facility Technical Progress Report

Fourth Quarter, CY 1993

\author{
DISCLAIMER
}

This report was prepared as an account of work sponsored by an agency of the United States Government. Neither the Ohio Power Company, the American Electric Power Service Corporation, or the United states Government nor any agency thereof, nor any of their employees, nor any of their contractors, subcontractors, or their employees makes any warranty, express or implied, or assumes any legal liability or responsibility for the accuracy, completeness, or usefulness of any information, apparatus, product, or process disclosed, or represents that its use would not infringe privately owned rights. Reference herein to any specific commercial product, process or service by trade name, trademark, manufacturer, or otherwise, does not necessarily constitute or imply its endorsement, recommendation, or favoring by the ohio Power Company, the American Electric Power Service Corporation, and the United States Government or any agency thereof. The views and opinions of authors expressed herein do not necessarily state or reflect those of the ohio Power Company, the American Electric Power Service Corporation, and the United states Government or any agency thereof.

\author{
Prepared by: \\ American Electric Power Service Corporation \\ Columbus, Ohio 43215
}

Prepared for:

The United states Department of Energy under DOE Instrument NO. DE-FC21 $89 \mathrm{MC2} 6042$

January, 1994 


\section{INTRODUCTION}

This is the seventeenth Technical progress Report submitted to the Department of Energy (DOE) in connection with the cooperative agreement between the DOE and Ohio Power Company for the Tidd PFBC Hot Gas Clean Up Test Facility. This report covers the period of work completed during the Fourth Quarter of CY 1993.

During this quarter, the Tidd Hot Gas clean Up system remained out of service for repairs following the september shutdown. Engineering activity this quarter was concentrated on implementing system enhancements to improve the reliability of the system in subsequent tests. The filter was fitted with all new candle elements and other modifications as discussed below.

On October 20, 1993" we presented the preliminary results of the Advanced Farticle Filter (APF) tegting during the previous quarter to the DOE at Morgantown. 
II. WORK ACCOMPLISHED DURING THE REPORTING PERIOD

\subsection{Detailed Design and Engineering}

A detailed design was made for the addition of nine purge nozzles to the APF hopper. The nozzles were added to the hopper during the fourth quarter outage. Six nozzles were added at one elevation and three other nozzles were added at a lower elevation. With the three original nozzles at the bottom of the hopper, there are now a total of twelve purge points. Figure 1 shows the design of the new nozzles.

An air reservoir was also added to one of the original purge nozzles in case a large blast of air is required to dislodge accumulated ash.

Based on operating experience with the APF, it was concluded that the filter pressure differential tends to become unstable, i.e., keeps increasing at gas temperatures above approximately $1400^{\circ} \mathrm{F}$. In order to allow full load operation of the Tidd Plant, which will produce gas temperatures as high as $1550^{\circ} \mathrm{F}$ and not impose excessively high pressure differentials across the APF, a means for cooling the gas upstream of the APF was devised. A new 6-inch line was engineered and installed this quarter which will allow $550^{\circ} \mathrm{F}-$ $580^{\circ} \mathrm{F}$ process air to mix with the gas in a pipe spool upstream of the filter. This line will be used as necessary to maintain the filter inlet temperature no higher than $1400^{\circ} \mathrm{F}$ during the next test run.

PFBC HGCU Test Facility

DOE Instrument No. DE-FC21 89MC26042
Technical Progress Report No. 17 Fourth Quarter 
As previously reported, the primary cyclone upstream of the APF was partially detuned late in the last test run and its effects were inconclusive. During this quarter, the shutoff valve in the spoiling air line was replaced with a ball valve to increase the capacity of the spoiling air. Further engineering studies have produced a plan for totally spoiling the cyclone, should that become necessary for stable filter operation. Basically, the method involves introducing additional air at the ash pickup nozzle at the bottom of the cyclone, thus preventing the removal of the ash from the cyclone dip leg. Eventually, the ash will fill up the dip leg and then be carried out with the main gas stream.

If complete cyclone detuning is attempted, it means that the dust loading to the filter will increase by a factor of 40 , from 500 to $20,000 \mathrm{ppm}$. The ability of the ash removal system to handle up to $3000 \mathrm{lb} / \mathrm{hr}$ of ash was evaluated carefully. The screw cooler should be able to pass the required ash loading, provided the cooling water temperature is reduced from $340^{\circ} \mathrm{F}$ to $100^{\circ} \mathrm{F}$. The lockhopper system will handle the higher flow but will be cycling every ten minutes or so. If the lockhopper system malfunctions even temporarily, the APF could fill with ash unless an emergency ash removal gystem is immediately available. The existing emergency ash removal line does not have sufficient capacity. Therefore, a second emergency ash removal line was engineered. This will consist of a 2-inch double extra strong pipe that will run from the screw cooler outlet pipe to a modified tee bend in the existing primary cyclone ash line. A Tungsten carbide nozzle will be installed at the end of the line to control the velocity in the pipe and dissipate the excess pressure drop. Materials were ordered for the new line and it will be

PFBC HGCU Test Facility DOE Instrument No. DE-FC21 89MC26042
Technical Progress Report No. 17 Fourth Quarter 
installed during the next quarter.

Following the last test series, the back pulse solenoid valves were inspected and found to be galled on both the piston and cylinder walls. Much engineering activity was devoted to developing a plan for modifying the valves to eliminate this problem. The valve pistons were stellite coated and the valve body boreg were nickelboron plated to improve resistance to galling. Following these modifications, the valves successfully underwent accelerated cycle testing to verify the design.

One back pulse tube was cut up and examined for degradation. Microcracking was evident on the inside surface of the tube, with cracks as deep as 0.020 inches. Based on this observation, it was decided to replace the Incoloy $800 \mathrm{HT}$ material with Haynes 230 alloy, which has better resistance to thermal fatigue. The new back pulse tubes were fabricated and installed during this quarter.

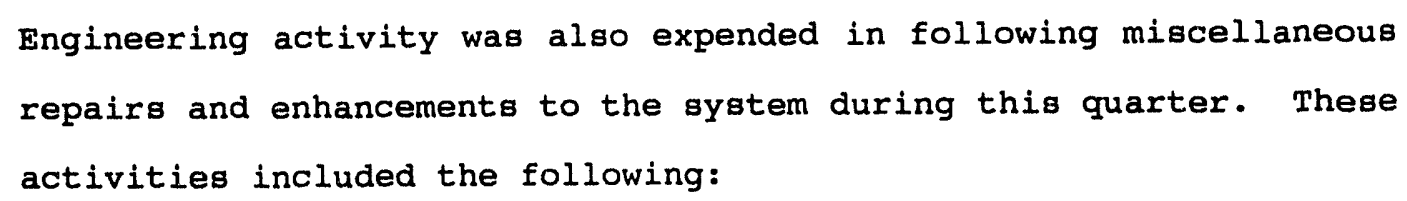

1. Repair of anchors in the APF head liner

2. Repair of thermocouples in the APF

3. Replacement of ash sampling isolation valves

4. Replacement of several other ball valves with high performance valves

5. Repair of the ash pickup nozzle in the backup cyclone ash vessel

PFBC HGCU Test Facility DOE Instrument No. DE-FC21 89MC26042
Technical Progress Report No. 17 Fourth Quarter 
6. Installation of the revised APF hopper vibrator, mounted outside the vessel, as described in the previous quarterly report.

\subsection{Westinghouse Engineering and Design \\ see attached appendix.}

7.0 Hazardous Air Pollutants

Engineering time was spent reviewing the design of the sampling hardware that is being supplied by Radian Corporation for hazardous air pollutant sampling. Several enhancements were given to Radian for inclusion in their design. 


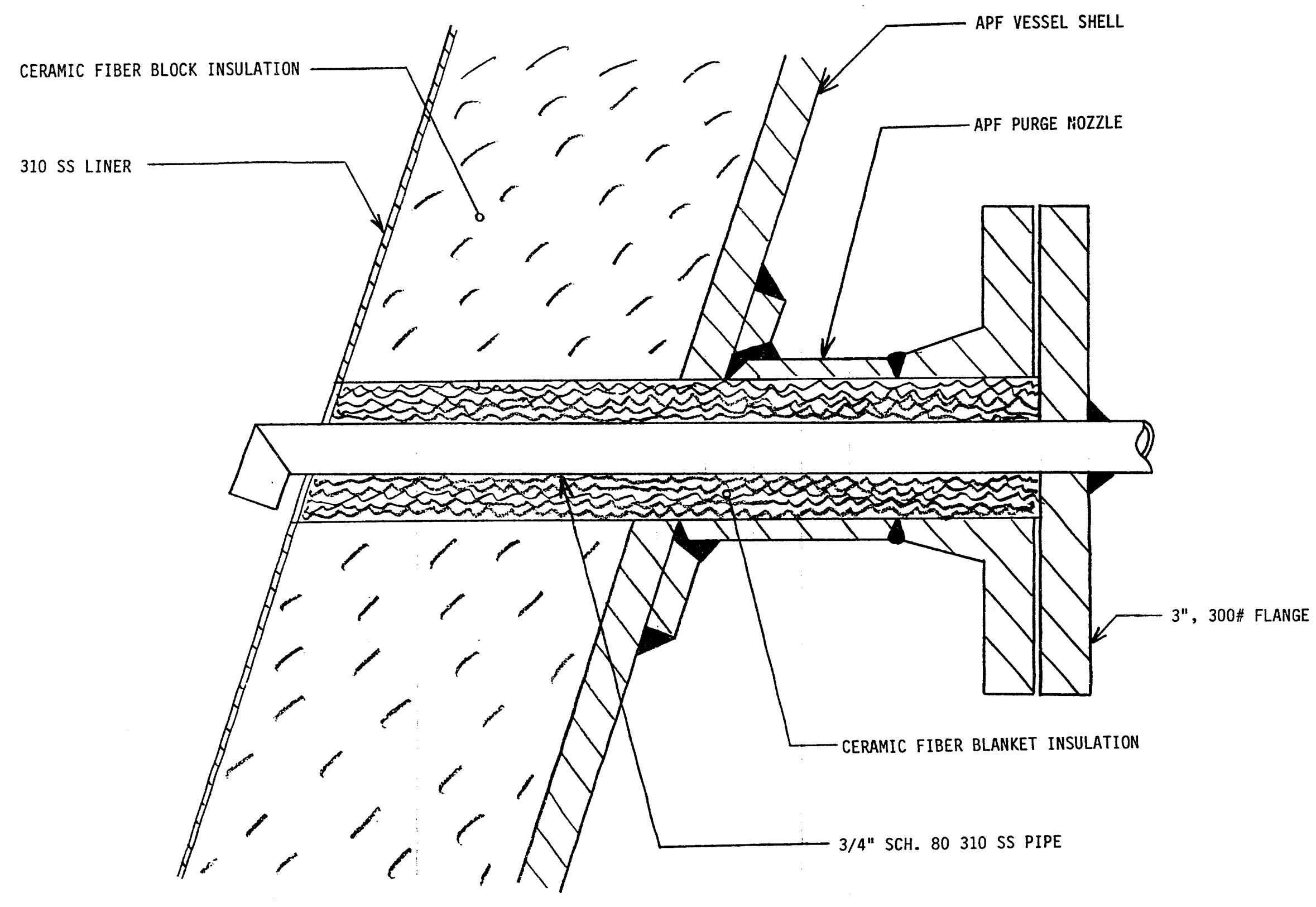


PFBC Hot Ges Cloen-Up Tost Program

AEPSC Eng.,Dosign a Project Support Work+hours

Budgan Vorsus Actual

Cumulative $\%$
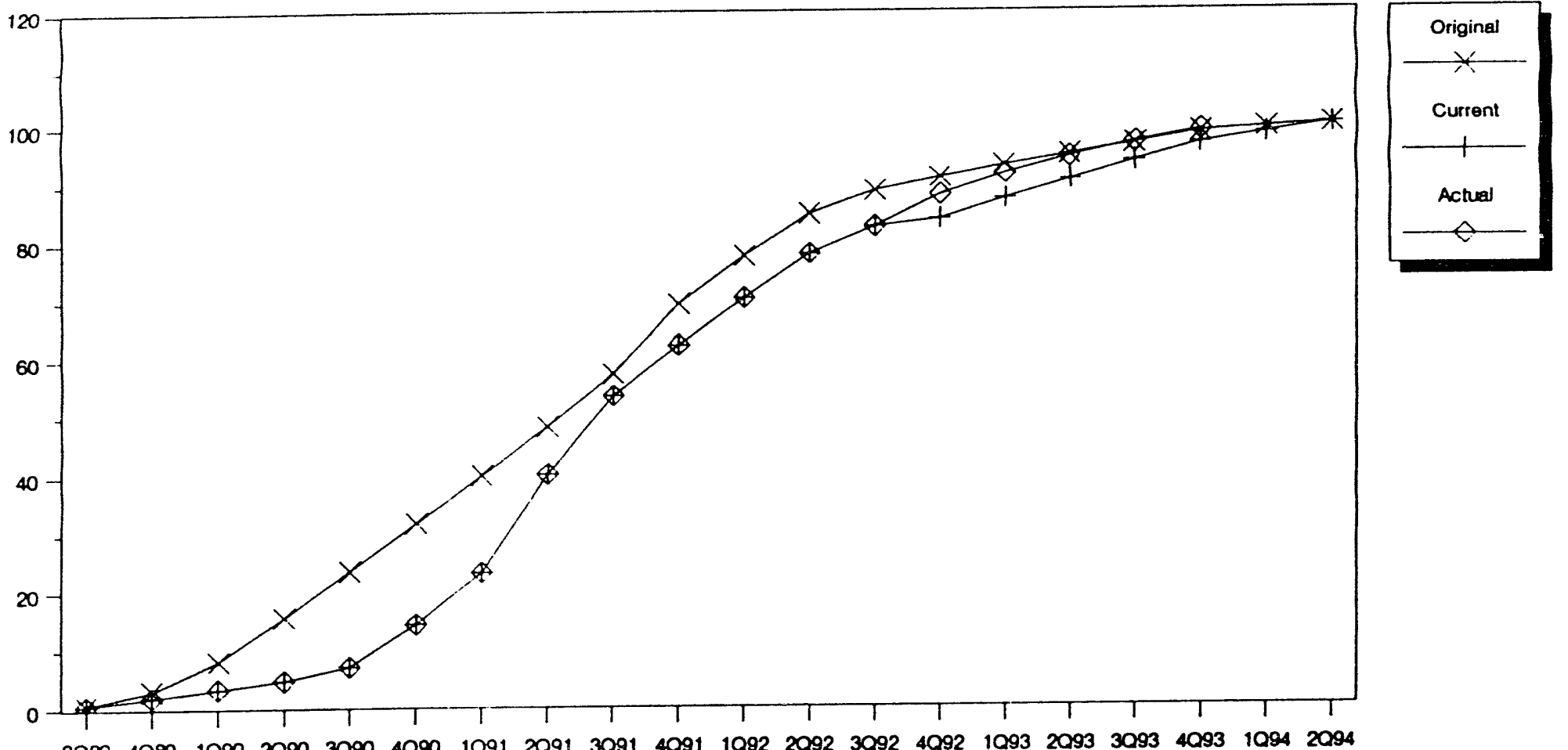

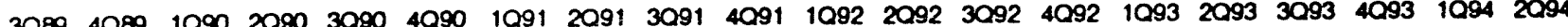

\begin{tabular}{|c|c|c|c|c|c|c|c|c|c|c|c|c|c|c|c|c|c|c|c|c|}
\hline & 3089 & 4089 & 1090 & 2090 & 3090 & 4090 & 1091 & 2091 & 3091 & 4091 & 1092 & 2092 & 3092 & 42392 & 1093 & 2093 & 3093 & 4093 & 1094 & 2094 \\
\hline Original & 0.8 & 3.2 & 8.1 & 15.6 & 23.6 & 31.8 & 40.0 & 48.2 & 57.3 & 69.2 & 77.4 & 84.7 & 88.6 & 80.9 & 83.1 & 94.9 & 86.7 & 98.6 & 99.3 & 100.0 \\
\hline Current & 0.6 & 2.0 & 3.4 & 4.8 & 7.1 & 143 & 23.3 & 40.2 & 53.4 & 62.2 & 70.2 & 77.8 & 82.5 & 83.8 & 87.2 & 80.5 & 93.7 & 96.7 & 98.4 & 100.0 \\
\hline Actual & 0.6 & 2.0 & 3.4 & 48 & 7.1 & 143 & 23.3 & 40.2 & 53.4 & 62.2 & 70.2 & 77.8 & 82.5 & 87.9 & 91.6 & 94.5 & 96.9 & 98.9 & & \\
\hline
\end{tabular}

Figure 2. 


\section{PFBC Hot Qns Claen-Up Test Pronrm}

\section{Cumulative Expenditures}

Budget Vorsus Actual

(in Thousends)

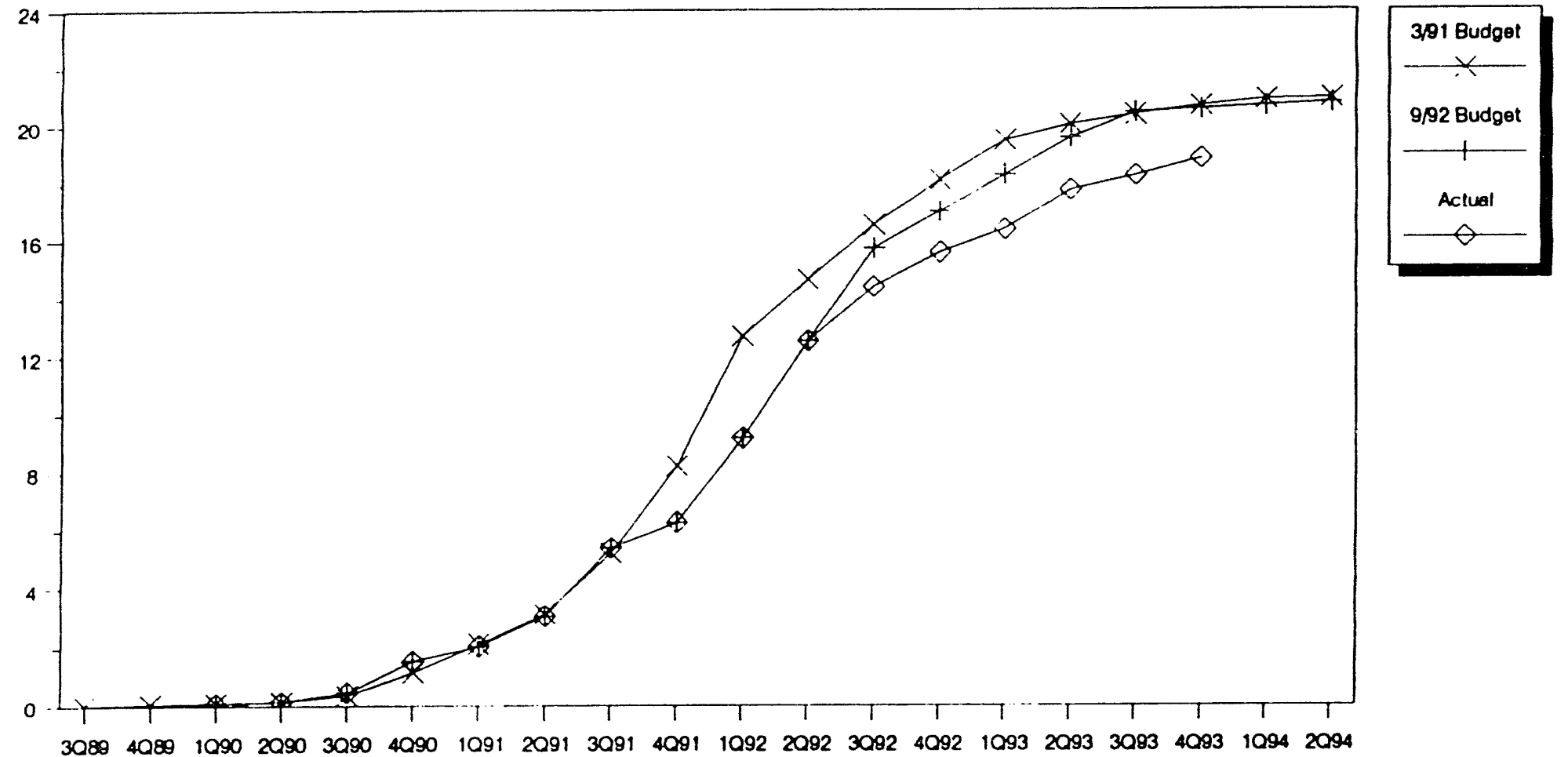

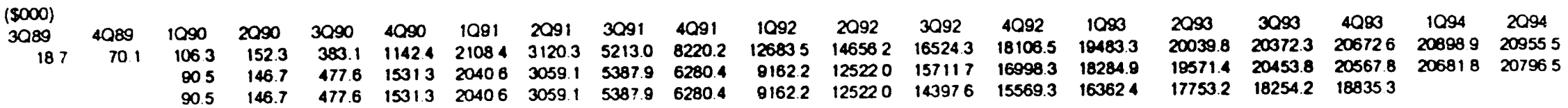




\title{
ADVANCED PARTICLE FILTER
}

\author{
Technical Progress Report No. 14 \\ October through December 1993
}

Prepared by
Westinghouse Science and Technology Center Pittsburgh, Pennsylvania

\section{For}
American Electric Power Service Corporation Columbus, Ohio

AEPSC Contract No. C8014 


\section{TIDD ADVANCED PARTICLE FILTER}

\subsection{INTRODUCTION}

The APF was shut down on September 23, 1993 and no operation was performed during this quarter. This report summarizes inspection, candle reinstallation, retrofit and accelerometer testing conducted during this three month outage.

\subsection{INSPECTION}

The APF internals were removed from the vessel on September 30, 1993. Inspection of the candles, including the distribution of failures, the nature of the fractures, the extent of ash bridging and the changes in material properties, has been discussed in quarterly technical report number 13 . Additional observations to note include the following:

(1) Some cast filter holders were slightly bent - generally in a direction radially outward from the cluster. (It is speculated that the same stresses from ash bridging that may have caused candle failure could also have produced creep and deformation in the type 310 stainless steel holders at operating temperature.)

(2) The APF vessel head liner was deformed inward around the opening for the outlet nozzle. Three of six studs used to hold this liner in place were broken. (It is speculated that this deformation occuried as a result of misalignment of the outlet nozzle liner and the adjoining downstream pipe work during assembly.) 
(3) Cross sectional examination of one Incoloy $800 \mathrm{HT}$ back pulse pipe showed cracking had initiated on the inside pipe surface. (Similar cracking noted for pulse pipes in the APF at Karhula is attributable to thermal fatigue urising from repetitive "cold" pulsing of this normally hot structure.)

(4) Thermocouples and pressure taps passing through insulation in the APF vessel head were noted to be badly corroded and/or embrittled. It is likely that this condition contributed to some lost data during the last run.

Section 4 discusses the fixes and rework conducted to address these issues.

\subsection{CANDLE REINSTALLATION}

Concern regarding potential residual candle damage in the unbroken candles suggested that all candles should be replaced with new ones. The only exceptions to this decision were nine thoroughly tested surveillance candles which were reinstalled at position numbered 16 for each of the plenums. This position was selected because it was deemed most visible from the vessel inspection nozzles located at $0^{\circ}$ (North), $120^{\circ}$ (ESE) and $240^{\circ}$ (WSW). A fail-safe/regenerator device was installed in the filter holder directly above each of these nine surveillance candles. (This fail-safe design has been recently operated in the APF at Karhula, Finland.)

Prior to candle installation, ash was removed outside (dirty side) and inside (clean side) of the metal structures by brushing and vacuuming. Filter holders were checked for plumb. Approximately 25 holders in the middle and bottom plenums were found to vary from plumb by more than $\pm 1^{\bullet}$. These were straightened by mechanical bending. Of the filter holders which were straightened, one cracked at the juncture 
between its 1-1/2" neck and 3-1/2" body. The crack was circumferential and approximately $1 "$ long. The crack is attributable to reduced ductility of type 310 stainless steel following exposure in the temperature range for formation of sigma phase.

The filter holder was repaired by seal welding. Weldability was first checked by applying a bead on plate weld to a surveillance coupon removed from the vessel head. Visual and penetrant inspection confirmed soundness of the test weld and associated heat affected zone. The filter holder crack was then repair welded, visually inspected and penetrant tested.

All candles were reinstalled using new gaskets and new bolting hardware. New filter holder rings, with a collar on their inside diameter to ensure gasket containment, had previously been installed in all bottom plenum filter holders (ref. quarteriy report no. 12, $\mathrm{p}$ 1). Such rings were also used for top and middle filter holders during the present installation. Bolting holes in all bottom cast nuts were redrilled to increase the hole diameter from 0.281 inch to 0.343 inch. This enlarged hole has been demonstrated to facilitate bolting during candle installation in the APF at Karhula.

\subsection{RETROFIT WORK}

Deformation of the vessel head liner was of modest magnitude and, since it did not interfere with APF functions, it was not reformed. All accessible gaps were filled with Fiberfrax. The three support studs were repaired by adding a threaded extension rod to the remaining end of the stud. Support was then reestablished as usual by placing a large washer over the stud, threading a nut over the extension and tack welding the nut to the rod to fix it in place. A small weld crack around the liner outlet was seal welded. 
Cracking of Incoloy $800 \mathrm{HT}$ back pulse pipes has been addressed at Karhula by inserting a tube inside of the pipe to act as a thermal barrier. This approach was investigated to resolve the cracking noted in pulse pipes at Tidd, however, sleeving was not utilized because of limited bore diameter of the APF outlet nozzles. Alternatively, the pulse pipes were remanufactured using a more fatigue resistant material - Haynes Alloy 230.

Essential thermocouples and pressure taps in the vessel head were replaced with new material. Where compression fittings were used to connect pressure tubing, the bore of the tube was reamed at its ends to clean out swaged material to the nominal tube inside diameter. All new thermocouples installed were clad of Inconel 600 sheath. This material may provide improved resistance to corrosion and embrittlement and may extend the life of the thermocouple leads.

Unreliable performance of back pulse valves has been attributed to galling. Parallel path approaches were initiated to resolve this issue. These actions are described in the memo in Appendix A. The nearest term approach that has been demonstrated to resist galling involves weld overlay cladding of Stellite 6 on wear surfaces of valve pistons and electroplating of nickel-boron on wear surfaces of valve bodies. At this time all 7 (3 primary, 3 backup and 1 spare) pulse valves at Tidd have been reworked with Stellite and nickel-boron.

Continuing concern regarding ash discharge from the APF vessel has prompted additional actions to enhance ash flow. They include:

(1) Relocation of the liner vibrator from inside the manway to a mount on the outside of the manway flange. This arrangement is anticipated to improve 
the reliability of air supply/exhaust hoses and to enhance the serviceability of the vibratory device.

(2) Addition of an "air cannon" for nozzle 2. An air accumulator tank has been installed to provide a sudden blast of air in the APF hopper if discharge problems are encountered.

(3) Addition of nine (9) new purge air nozzles. Nozzles have been added to the APF hopper to provide additional flexibility to dislodge ash by purging at various elevations and locations.

\subsection{ACCELEROMETER TESTING}

A series of tests have now been completed to evaluate the dynamic behavior of the Westinghouse candle cluster during a pulse cleaning event. A second test has now been performed to measure the acceleration of a bottom plenum of the APF resulting from room temperature pulse cleaning. Three accelerometers were epoxied to the B cluster bottom plenum plate. The $\mathrm{x}$ and $\mathrm{y}$ accelerometers were mounted on the side of the plate 90 degrees apart and the $\mathrm{z}$ accelerometer was mounted on the bottom surface of the plate as close to the center as possible ( 4 inches in from the edge of the plate). The plenum acceleration resulting from 12 room temperature pulses of cluster B bottom were measured with an HP 3562A Dynamic Signal Analyzer and captured to diskette. Two analyzer setups were used:

High Frequency Setup with a measurement period of 1.5 seconds and frequencies up to $5 \mathrm{kHz}$. 
Low Frequency Setup with a period of 15.5 seconds and frequencies to $500 \mathrm{~Hz}$.

A high frequency and low frequency measurement was taken for each accelerometer at each of the two pulse pressures ( 350 and $700 \mathrm{psig}$ ) for a total of 12 measurements.

The low frequency acceleration appears to be damped. The high frequency measurements show the highest accelerations. The highest acceleration (16 g's) occurred during a 700 psig pulse in the $x$ direction. This plenum acceleration data will be used by Adapco Analysis \& Design in a candle failure analysis.

In June, 1993 APF candle acceleration tests were performed during room temperature pulse cleaning at 350 and 700 psig. Consistent with the plenum tests described above, low frequency $(0-312 \mathrm{~Hz})$ measurements indicated low candle accelerations ( $0.7 \mathrm{~g}$ 's maximum in the radial direction).

\subsection{KARHULA PARTICLE FILTER TESTING}

A 500 hour test run was completed on the Westinghouse candle filter installation at the Ahlstrom $10 \mathrm{MW}_{\mathrm{t}}$ pressurized fluidized bed combustion pilot plant facility at Karhula Finland. The filter unit met all performance goals while operating on a U.S. powder river coal (Black Thunder). Inspection of the 128 candle filter element unit following the test period showed the system to be in excellent condition. Several of the candle elements have been returned to STC for material characterization follow-up. Operation of the unit is scheduled to resume early February.

Characterization of candle filters exposed prior to the most recent ( 500 hour) test run is described in Appendix B to this report. 
APPENDIX A

ATKOMATIC PULSE SOLENOID VALVE REWORK

A-1 


\title{
ATKOMATIC PULSE SOLENOID VALVE REWORK
}

\author{
G. J. Bruck \\ Advanced Fossil Energy Systems \\ December 17, 1993
}

\subsection{INTRODUCTION}

\begin{abstract}
Severe adhesive wear (galling) has been noted between pistons and valve bodies for the 2 inch Atkomatic model 35871 pulse solenoid valves at Tidd. Maintenance work has included frequent honing and hand sanding (deburing). Such extensive rework during operation is unacceptable. This brief memo documents the current status of corrective actions undertaken to improve valve performance.
\end{abstract}

\subsection{CORRECTIVE ACTIONS}

\subsection{Unsuccessful Valve Changes}

The galling was noted to be located next to flat areas on the valve pistons (and the corresponding surfaces within the valve bodies). The first action taken to correct galling was to minimize the size of these areas. New pistons were supplied by Atkomatic with flats shortened from 1.000 inch to 0.300 inch (see sketches in Appendix A.) Subsequent operation with the newly designed pistons still produced galling that required frequent maintenance.

The second action to correct galling involved Teflon coating of all wear surfaces within the valve. Atkomatic supplied Teflon coating of both pistons and valve body 
bores. Subsequent testing of such coated valves proved unsuccessful. In separate tests Teflon coated cylinder with Teflon coated body and Teflon coated cylinder with uncoated body, both failed in the open position in less than 200 cycles.

A third action to correct galling in rolved using an Atkomatic-supplied piston made of Naval Brass. Tests with this cylinder in uncoated and Teflon coated bodies also resulted in valve failure in less than 200 cycles.

\subsection{Valve Changes Under Current Test}

Alternative valve changes being undertaken involve changing valve body and piston materials to improve resistance to galling. The following table summarizes the status of these part preparations and tests. Technical information on the Gall-Tough stainless steel and bronze alloy 24059 may be found in Appendix B. For the Gall-Tough and bronze pistons, two piston geometry options are being offered. The first has a 0.250 inch long flat area. The second has the same 0.250 inch flat with an additional $35^{\circ}$ bevel. Material certificates and design details are described in Appendix $C$.

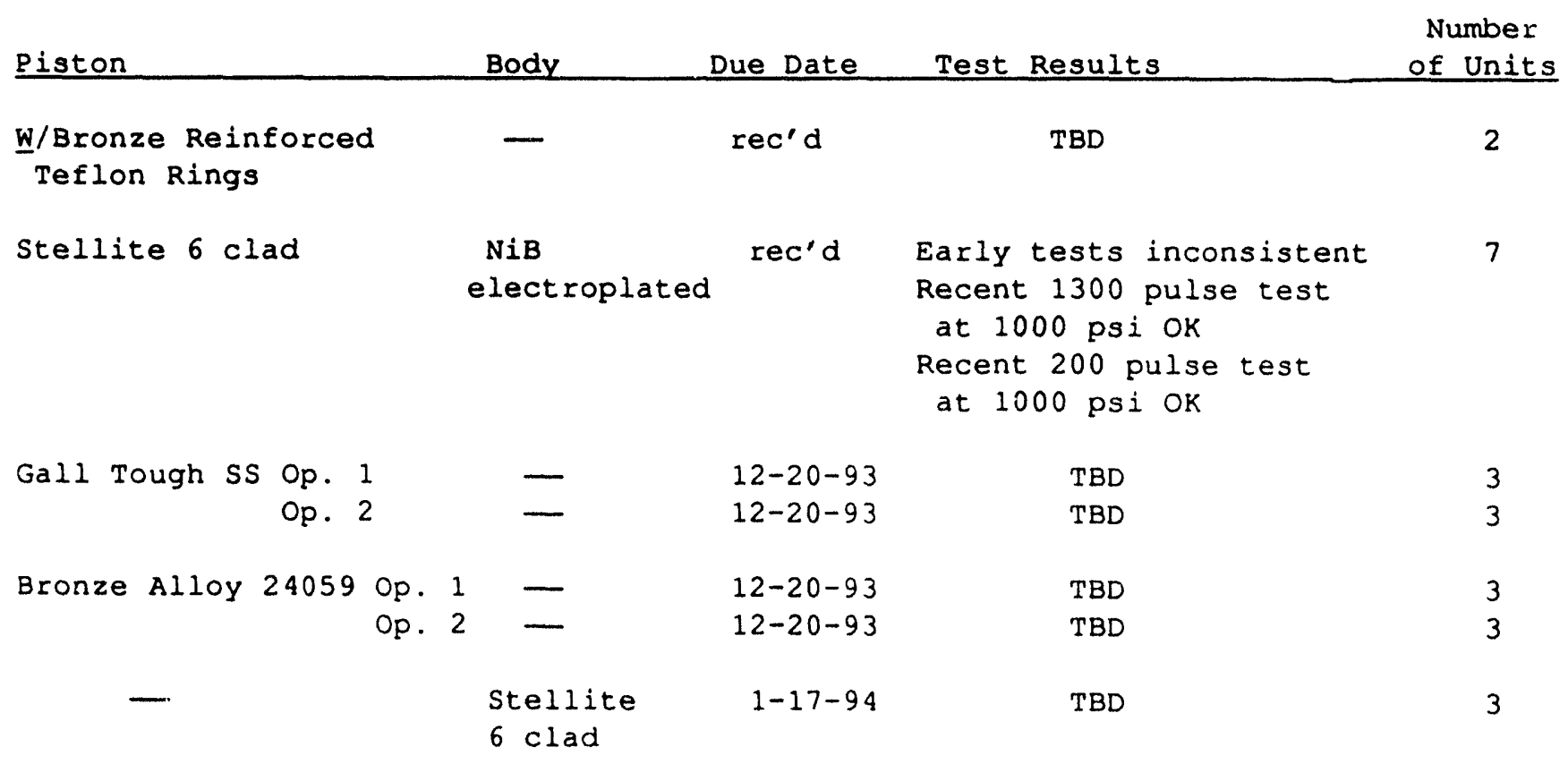


APPENDIX A

SKETCHES OF ORIGINAL AND MODIFIED PISTON DESIGN 


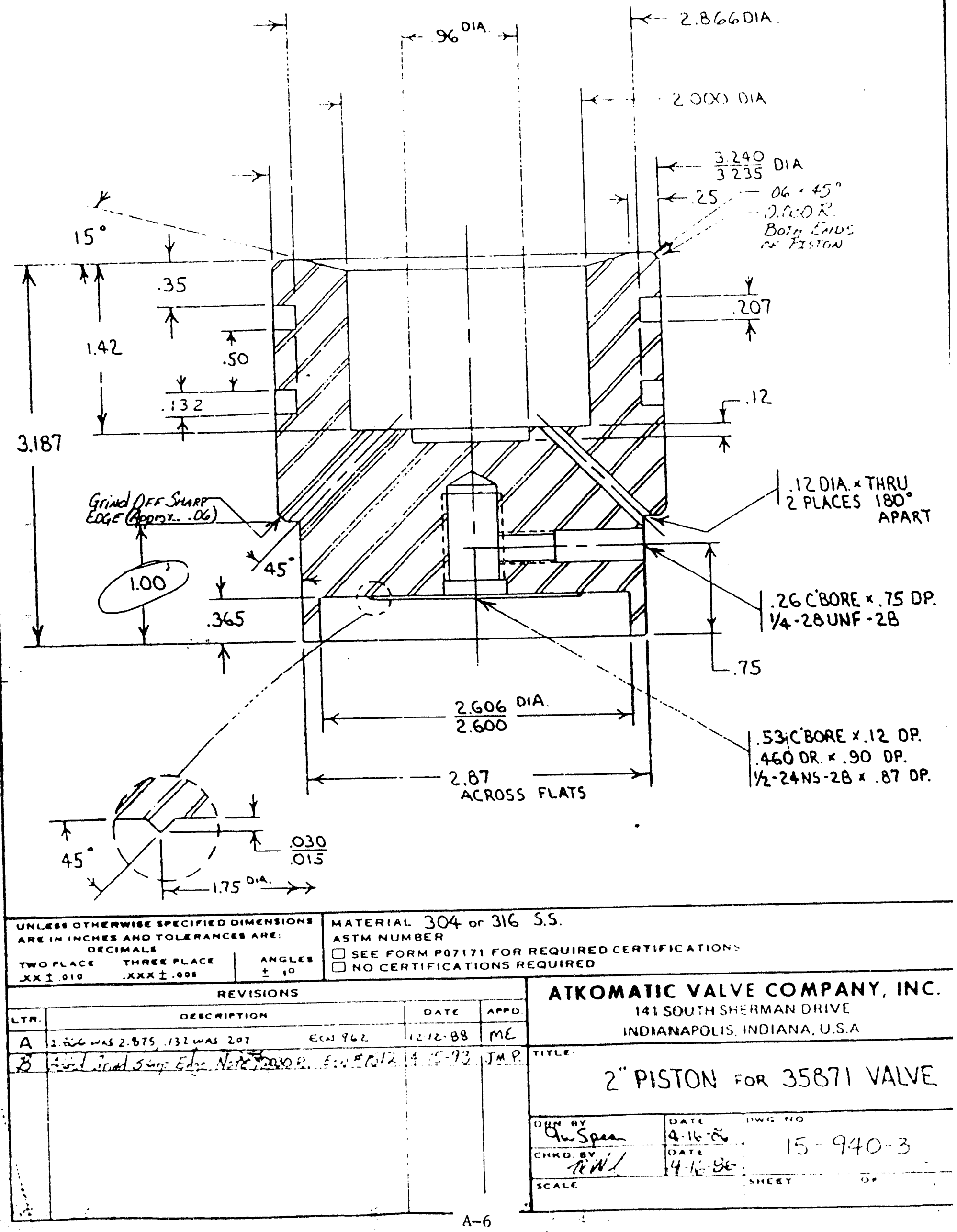




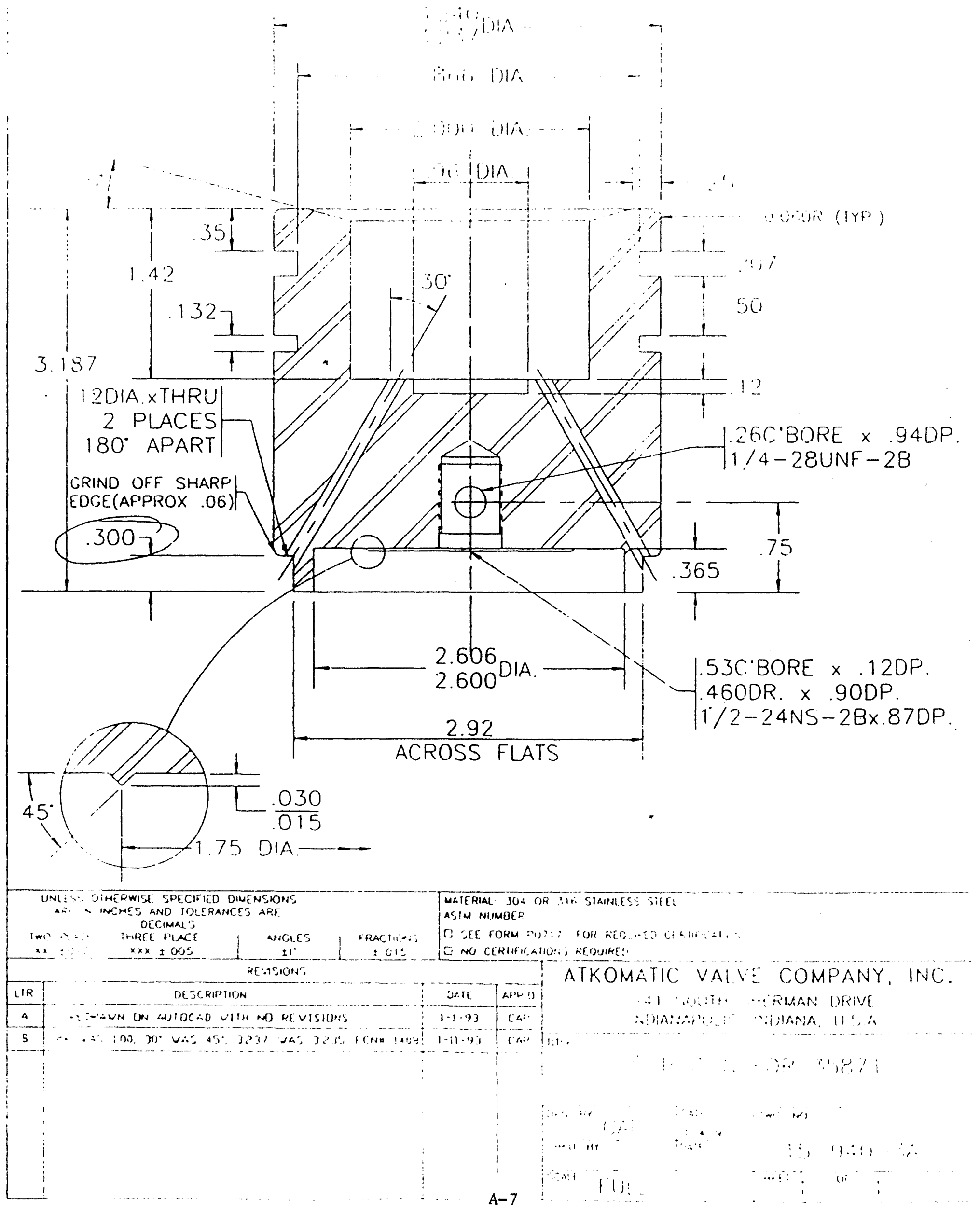




\section{APPENDIX B}

TECHNICAL INFORMATION

ON

GALL-TOUGH STAINLESS STEEL

AND

Mil-B-24059 Aluminum Bronze 
Genllemen,

Please find altached teclinical information on the materials we are proposing to use and comparable information on the materials wo havo tried previously.

"Gall-Tough" is the trade name of a Carpenter stainless steel specifically formulated to resist galling. It contains high-levels of manganese and silicon, and it has bsen nitrogen strengthened. The testing indicales it is subsinntially resistant to galling. I have also included some background Information on galling and some of Carpenter's test results.

I have included somo informatloin an standard $316 \mathrm{~L}$ stainless steel for comparison with the above.

Please find attached specifications for aluminum bronze C63200, MaL-B-24059, this material a!so has a high-manganese content to Improve its galling charactaristics. It also has a much higher tensile strength than the brass we tried previously. Atkomatic has had success in the past using this material to relieve galling problems.

I have included some information on standard Leaded Naval Brass for comparison with the above. 

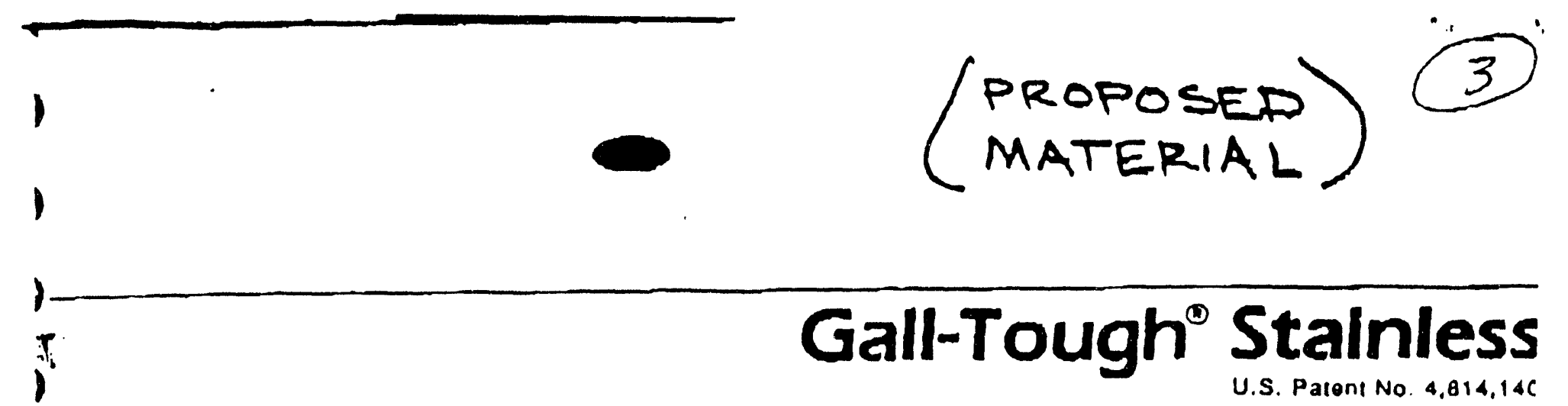

(S20161:

\begin{tabular}{|c|c|c|}
\hline 1 & Type Analysis & 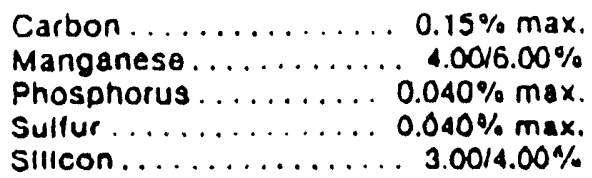 \\
\hline
\end{tabular}

) Descrlption

1

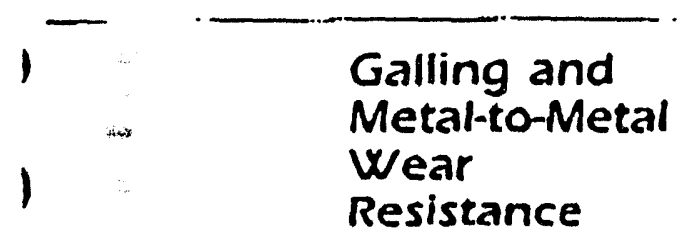

1

1

1

1

)

\section{Appllcatlons}

Gall-Tougn stainless is a lifgli. silicon, hlgh-manganese, nitrogon strengthened, austenltlc stainless alloy which possesses superior sell. matod galling and molel-lo-mota! wear realetence.
When compared to other standerd stainiess steels, the soll.mated galling resistance and metal-to-molal wear roslatance of Gall-Tough
- Teeting al higher atrese not pertormed

- Galled al laweel illeces moluated

Gall-Tough oldelnlece may be
Chromlum......... 15.0018.00\%

Nickel ... . . . . . . . . . . . 4. 4.0018.00\%

Niltrogon . . . . . . . . 0.080.20\%
This alloy displays hlghor strongth and hlgh temperature oxidation reslatance than Typo 304 olalnloss with comparable corrosion realstance dopending on the environment.

Qalling and Wear Teat Propertios-Vartous Alloye

Galling tost involves rotatling a conipressively louded 1/2" $(12.7 \mathrm{~mm})$ diamotor button agalnst a block counterclockw/se $360 \%$, clockwise $360^{\circ}$. and counterclockwlse $380^{\circ}$ and dotermining the highost strese at which vielble gallins damage doas not occur. Metal-10-melal wear tests were conducled for 10,000 cycles using crossed motal cyllndors par ASTM G83.

\begin{tabular}{|c|c|c|c|c|}
\hline \multirow{3}{*}{ Alloy } & \multicolumn{2}{|c|}{ Galling Toet } & \multicolumn{2}{|c|}{ Wear Teel } \\
\hline & \multicolumn{2}{|c|}{ Threshold Gelling sirese } & \multicolumn{2}{|c|}{ Avo. Fotal Volume Lose, $\mathrm{mm}$} \\
\hline & $k=1$ & MPo & $100 \mathrm{~mm}$ & $400 \mathrm{~mm}$ \\
\hline $\begin{array}{c}\text { Gall-Tuugh staliness } \\
\text { Type } 440 C \text { (HAC 56) } \\
\text { Type } 304 \\
\text { Type } 430\end{array}$ & $\begin{array}{r}+15 \\
2 \\
<10 \\
<110\end{array}$ & $\begin{array}{c}103^{\circ} \\
14 \\
7 \cdots \\
7 \cdots\end{array}$ & $\begin{array}{l}5 \\
9.5 \\
29 \\
230\end{array}$ & $\begin{array}{c}5.5 \\
25 \\
172\end{array}$ \\
\hline
\end{tabular}
considered for appllcallons in which parts are in relative motion under load wlthout lubrlcanta.

Polenllal applicallons Include:

Chain link convoyer belto and olher componenle in lood and drug proceseing industries

- Bolts, nuta and othor lasteners

- Flllings for pumps and valves

Lugoage carouede in ale torminals 


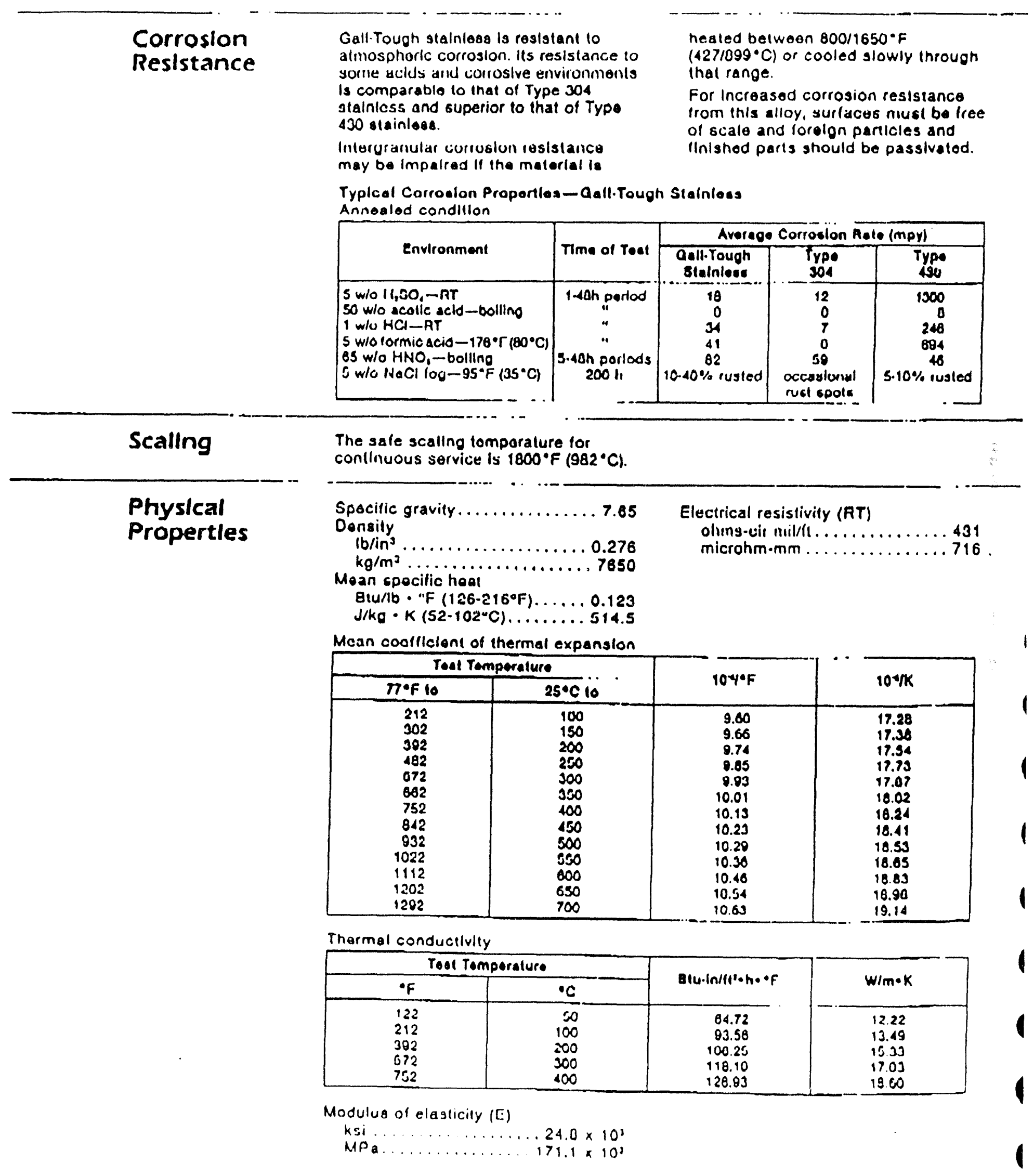



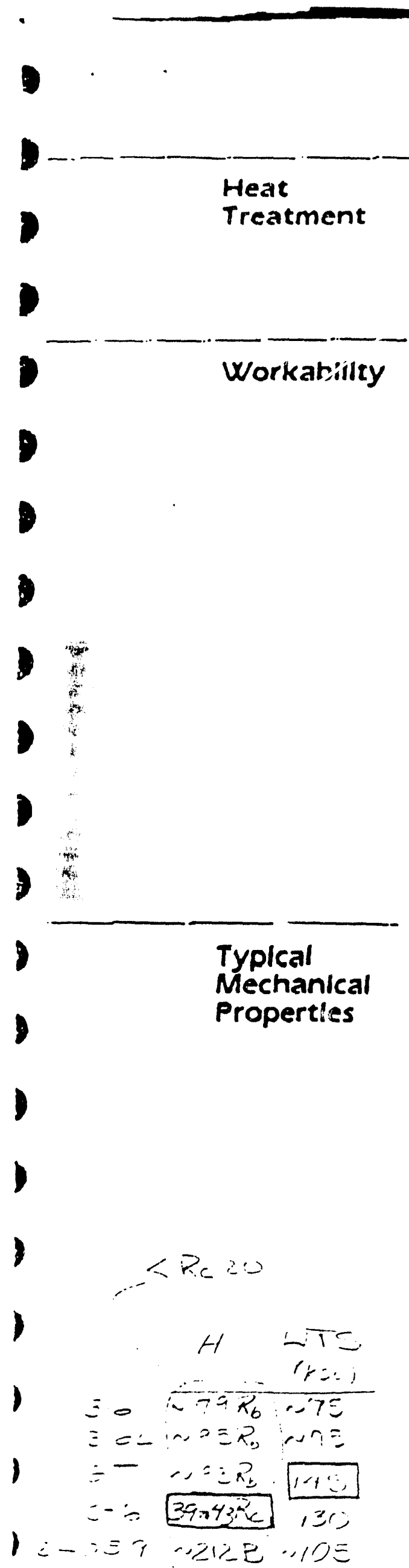

\section{Annealling}

Heal $101800 / 2000^{\circ} \mathrm{F}\left(1038 / 1093^{\circ} \mathrm{C}\right)$ and quench in water. Typlcally, hardness as annealod is Rockwoll 805 .

\section{Hardening}

Gall-Tough stalnloss cannot be

hardenod by noat troatmont; howaver,

\section{Hot Working}

Gall-Tough stalniess can bo readily forged, hot rolled, not headed and upsel.

For hot working, heal unitormly to $2100 / 2300^{\circ} \mathrm{F}\left(1140 / 1280^{\circ} \mathrm{C}\right)$. Prohoallng to an intermediale temperature is not requlred. Oo not forge below $1700^{\circ} \mathrm{F}\left(827^{\circ} \mathrm{C}\right)$. Forgings can be alr cooled wilhoul danger of cracking.

For maximum corrosion resistance, annealing after hot working is roquired.

\section{Cold Working}

Gall-Tough stalniess la readily oold wurked by conventlonal methods.

Cold working causes manensitlc iransformation in Gafi-Tough stainloss, resulting in a sloniflcant increase in maonollc pormeabillity.

Because of its motastebllity, GallTough stalriless is characterlzed by a nigh renslle strength in both armealed and cold worked condlions. this malerlal can bc hardenod inrough cold work.

\begin{abstract}
Meahlnabllily
Gell. Tough sialnless machineo at about $50 \%$ of the rates used for Type 304 stainless. Its machinability to similar to that of other nlirogen. strengthened alloys, llke 22Cr-13NI. $5 \mathrm{Mn}$ ateinless. A rigld solup, hoavy posifive foods, and ample coolant flow ere recommended.

Wolding

Call-Tough stainleas oan be sallstactorlly wolded by the shlolded fuelon and reslstance wolding processes. Oxyacetylene wolding is not recommanded alnco oarbon plekup in the weld may occur. Whon a lliler molal is required. consider AWS EJEA2 10 wolding consumables which should provide wolds with atrength approeching that of the bese motal. If hlgh wold strength is not necessary. then conold or EJER3OS.
\end{abstract}

Rosistance to intergranular corrosion cen be rostored by a postwold annoallng treatmont.

Typleal Room Tomperalure Mochanical Properiles-Qall-Tough stainleee Annealed bar and wire

\begin{tabular}{|c|c|c|c|c|c|c|c|}
\hline \multirow[t]{2}{*}{ Eection Sizo } & \multicolumn{2}{|c|}{$\begin{array}{l}0.2 \% \text { Yold } \\
\text { strmoth }\end{array}$} & \multicolumn{2}{|c|}{$\begin{array}{c}\text { Uilimato } \\
\text { Tonelies Sirengenth } \\
\end{array}$} & \multirow{2}{*}{$\begin{array}{c}x \\
\text { Eonomitan } \\
\ln 40\end{array}$} & \multirow{2}{*}{$\begin{array}{c}\text { \% } \\
\text { neduction } \\
\text { of Area }\end{array}$} & \multirow{2}{*}{ Roctivell B } \\
\hline & ked & $M P_{e}$ & kel & MPe & & & \\
\hline $\begin{array}{l}10(25.4 \mathrm{~mm}) \mathrm{rd} . \\
250^{\circ}(6.35 \mathrm{~mm}) \mathrm{ra} .\end{array}$ & $\begin{array}{l}53 \\
66\end{array}$ & $\begin{array}{l}365 \\
455\end{array}$ & $\begin{array}{l}145 \\
156\end{array}$ & $\begin{array}{l}1000 \\
1070\end{array}$ & $\begin{array}{l}59 \\
70\end{array}$ & $\begin{array}{l}64 \\
73\end{array}$ & $\begin{array}{l}93 \\
03\end{array}$ \\
\hline
\end{tabular}

Trplcal Elevated Tomporalure Tenalle Propertins-Oall-Tough stalniese Annealed 1" $(25.4 \mathrm{~mm})$ dlamoler bar

\begin{tabular}{|c|c|c|c|c|c|c|c|}
\hline \multicolumn{2}{|c|}{$\begin{array}{c}\text { Toet } \\
\text { Tomperature }\end{array}$} & \multicolumn{2}{|c|}{$\begin{array}{l}\text { 0.2X Ylold } \\
\text { strength }\end{array}$} & \multicolumn{2}{|c|}{$\begin{array}{c}\text { Ullimore } \\
\text { Tonalle Strength }\end{array}$} & \multirow{2}{*}{$\begin{array}{c}\text { Songation } \\
\ln 40\end{array}$} & \multirow{2}{*}{$\begin{array}{c}\text { \% } \\
\text { Acdication } \\
\text { of ares }\end{array}$} \\
\hline • $F$ & ${ }^{\circ} \mathrm{C}$ & hal & MPo & kal & MPo & & \\
\hline $\begin{array}{c}\text { Aoom } \\
400 \\
800 \\
1200 \\
1600\end{array}$ & $\begin{array}{r}\text { Tomo } \\
254 \\
427 \\
649 \\
871 \\
\end{array}$ & $\begin{array}{l}53 \\
30 \\
27 \\
25 \\
10\end{array}$ & $\begin{array}{l}365 \\
207 \\
168 \\
172 \\
131\end{array}$ & $\begin{array}{l}143 \\
81 \\
77 \\
50 \\
20\end{array}$ & $\begin{array}{l}1000 \\
558 \\
531 \\
407 \\
135\end{array}$ & $\begin{array}{r}50 \\
63 \\
57 \\
58 \\
190 \\
\end{array}$ & $\begin{array}{l}64 \\
70 \\
78 \\
70 \\
90\end{array}$ \\
\hline
\end{tabular}

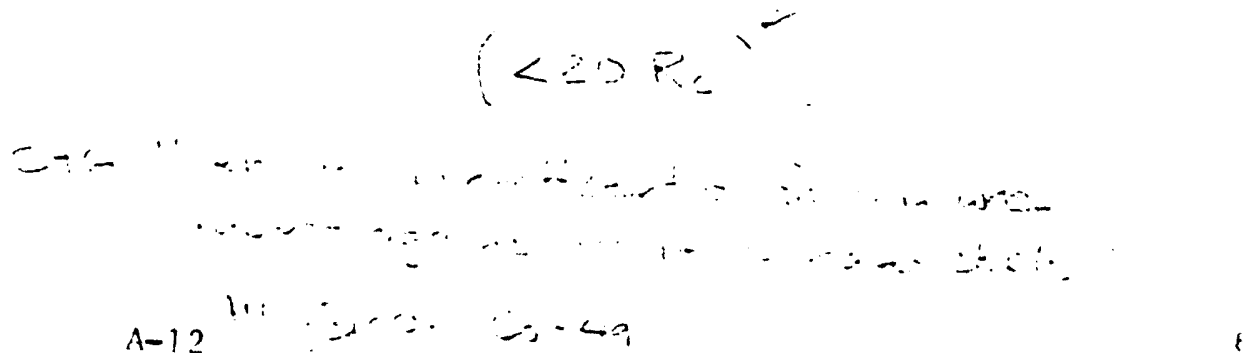




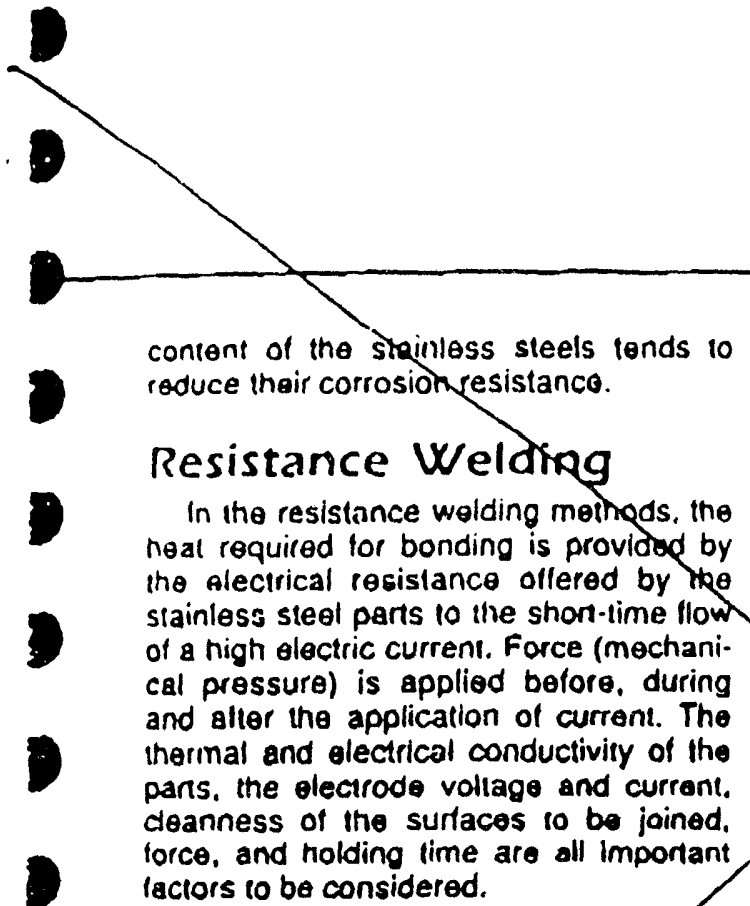

The austenitic stainless steels are oasity joined by resistance welding hathods. Tha very high electrical resistance of thesie grades allows the use of lower curronis and shorter timos yan those neces. sary for mild steel. Distortion and intergranular carbide precipitation can be mini. mized by limiting the current flow to the minimum time/nocessary to produce a sound joint forritic slaintess stools can be wolded by resistance mothods, but woldingtime should be kept to a minimum to 3roid grain coarsening and embritlepont. Manensitic stainloss steols can also be resisfances welded, but hardoning dooc

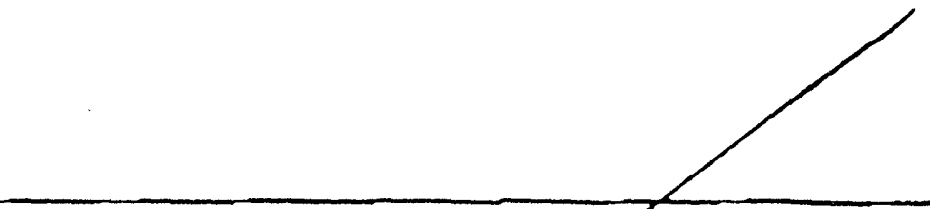

occur in the wald zung and the hoat-gf lecled zone and this can lead lo probjorns with cracking. Postweld heal ireahmonts are necessary 10 restore ductitity.

\section{Resistance Wetaing Methods}

Spot and Profection Welding: This rocess is limitod to strip and sheet thicknosses using a lap-typo joint. Fusion is accomburshed by applyino a high current to tho worm under pressure between suitabre tectrodes. The size and shape of the individual woldy are conirolled by the size and shape of the electrodes. Projection wolds are localized by the predetermined design of one of the quating parts which comains small projections of em. bossments. Aulomatic control is usually employed with spot or projection wolding. It is very important that the curtaces to b. poined be free from dirt, orease or other contamination. The welding pressure should be as unlform as possible, since pressure variations affect both current densily and electrical resistanco.

Seam Wolding: This process is the seme at spot wolding, excespt that the parts to be joined are held under pressure betwoen circular electrodes. This results
In a seriec of overlappling spot wels made progressively along a joint by rots ing tho electrodes. Warping and carbl precipitation in austenlic stainless ster can be avolded by ubmerging the we in walor or by dirueting a continuous th of wator upon the wold immedlately at sach seam is welded. The ferritic martenstic grades are not usually so: woldod.

Butt Welding and Flach Welding: butt welding the ends of bars or whe to joined are butted together by clart which also serve as electrodos. Pressi is appliad before the current is turned. and is maintained as melting occurs the foining laces. Flach wolding diff from butt welding in that the surfaces be joined louch very lightly initially. Wr the surfaces become motten due to heat produced by arcing between the pressure is applied to complete the fus phesess. With thase methode the surtar to bo joined should bo fality smooth cloan, and proper allonmont is absolut essential.

For lurther intortoation on welding. con tho Amertcan tron ind sted inallitio 11 16th Stroel N.W. Westipoton, OC 20036, I roquost the pubticallon antitied Wolding request the publicallon antited Wolding
Stainioss Sieals and Othos Jeining Mothods.

\section{(SOME \\ BACK GROUND FTEST Galling and Carpenter Stainless Steel}

Adhesive wear resulls frum Iwo metals oaing rubbed togolher under a load suffi. cient to break through the oxide film alsowing the mating surtaces to come into sontact at the high points. When the $\infty$. nesive force beiween the two motals exsoeds the strength of either metal, adhe. sion or cold welding occurs. Under low siross. this adhesion usually results in a complex process which woars away one or both of the mating surtaces al a slow ate. At higher stresses, cold wolding oc. surs more rapidly and over a greater area 0 : the mating surfaces. This higher dogree of cold weiding is relerrod to as gall. .ng and it may cause oquipment to soize or treeze up. If nol dealt with at the out. sel. oalling can be a worrisome and recuring problem. particularly in the applica. i on of slainloss sleels.

\section{Prevention}

The probability of galling occurring be. tween two melals can be minimizod of prevenied via 1) conirol of surlace rough. ness. 2) use of tubricants, 3) decreasing the contact load, and 4) slloy selection. O these, contaci load may bo the loast sub. ject 10 manipulation but. novertholess. must be comtrolled to the extent that excessive loads are evoided. Control of sur. face roughness, coupled with the use of a high-quality lubricant such as a moly-disulfide reinforced grease, is all that may bo required in many applications 10 pre. vent gating. The ideal surlace is one that is tree of machining buers, fins and tears and is not overly rough or overly smooth. For most applications, a suriace rough. ness in tho rango ol is 1050 microinches Xe (rms) is best.

\section{Alloy Selection}

Alloy saloction is a usolut rool a within the family of stainiess stools. i roletivoly recent approach to the contrs oalling Most stainless steols are $m$ suscopible to galling than carbon anc loy steols. However, nos all stainl steols sere equal in this respect and lsct. some are qulle resistant 10 gall that is, they have a high threshold ga stres: (TGS).

Throshold galling stress as discus ne:e is determined via a laboratory and is the stress required 10 produce no wten 1/2" $(12.7 \mathrm{~mm})$ diemeter ion is rotated against a llat plate witt lus casion. A single revolution of the ion 's normally used. However, $k$ evalcating galling-resistant alloys, : 
as Gall.Tough" ctainlese, a proceduro with three alternating revolutions is used lo simulato more severe service. Tho button and plate may be the seme or difler. ent alloys. Bocauso of the many possible oxiranoous lactors such as lubricalion. lamporaluro, roughiness uind oltiers, TGS is not nocossarily the lowest or, conversoly. the highest stross which will produce galling in actual practice. Nevertho. less. TGS has proved to be a valuable gulde in selecting stainless steols with increased rosistance 10 galling.

\section{Threshold Galling Stress for Carpenter Alloys}

To provtde the ueer and englneer with data which may be useful when selecting alloys for applications whero galling could occur, Carpenter's research laboratory the determined the threshold galling spess via the above procedure for many slainless sleols. For surre alloys. TOS was dotermined in two ways. In the first, both bullon and base plate wore the a amo alloy while in the second, base plale and bulturi were of two ditterent alluys or conditions. Results from the various losl are shown in Tables 1. II, and III. Note that Tables III and II present results for single-rotation 1ests. white Tabla presents results lor triplo-rotation tests.

Lurgo diflorences In TGS are seen among the variuus ulloys and, of course. as the TGS increases, so does the resis. lance lo galling. Differences less thall 2 to $4 \mathrm{ksl}$ ( 14 to $20 \mathrm{MPa}$ ) betweon alloys, how. over, are not considered to be significant for the single-rotation test.

\section{Some Pertinent Observa- tions Based on Our Data}

Contrary to popular bellel, cold working does not increase the resistance of an austenitic stalnless steet 10 galling and, in lact. can be delererious. On the other hand. Increasing hardness vla heat troaf-
Ing is gonorally bonoticial. Martonsitic stainless steals such as Type 410 and Type 416 in the annealed or tempered conditions are similar of 1088 resistant 10 gallirig than annoaled austanlic stairlosis stools such as Typo 304 and 316.

The addition of freo-machining addiIlves to both the 300 and 400 series stalnless stegls and the restriction of nickel in the nitrogen-strengthened alloys increase resislance lo galling.

The TGS lor a combination of Iwo dir. perent alloys lrequently lies belween the values for tho individual alloys in a sellmated condition.

Gall-Tough stainless has the highest TGS of any stainless stoel produced by Carpenter and should be considered for those applicalions now using alloys such as Types 302, 304, 310 and 22Cr.13Ni$5 \mathrm{Mn}$ whore galling has been a problom. or is likely to bo a problem.

\begin{tabular}{|c|c|c|c|c|}
\hline 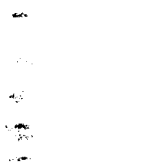 & \multicolumn{4}{|c|}{$\begin{array}{l}\text { Table I } \\
\text { Triple-Rotallen }\end{array}$} \\
\hline Nloy & Conditlan & $\begin{array}{l}\text { Roohwall } \\
\text { Hardacess }\end{array}$ & $\begin{array}{l}\text { Theoshold } \\
\text { Qulline } \\
\text { strose } \\
\text { hellMPa }\end{array}$ & Alloy \\
\hline $\begin{array}{l}\text { Gall Tough. } \\
\text { Gall-Tough } \\
\text { Gall-Tough } \\
\text { Iype } 4 \text { HoC } \\
\text { Cuslom } 455\end{array}$ & $\begin{array}{l}\text { Mill Annealed } \\
\text { Cold Drawn } \\
\text { Cold Drawn } \\
\text { Tempcred } 400^{\circ} \mathrm{f} \\
\text { H9so }\end{array}$ & $\begin{array}{l}B 92 \\
C 28 \\
C \quad 30 \\
C 58 \\
C \quad 46\end{array}$ & $\begin{array}{cc}15^{\circ} & 103^{\circ} \\
15^{\circ} & 103^{\circ} \\
15^{\circ} & 103^{\circ} \\
2 & 14 \\
21^{\circ} & <7^{\circ} .\end{array}$ & $\begin{array}{l}\text { Type } 304 \\
18-18 \text { PLUS } \\
18 \mathrm{Cr}-2 \mathrm{Ni}_{1} 12 \mathrm{M}_{11} \\
\text { Tyne } 430\end{array}$ \\
\hline
\end{tabular}

Conation

Annoalod

Ainealed

Annedied

Annoaled

\begin{tabular}{|c|c|c|}
\hline $\begin{array}{l}\text { Rochwall } \\
\text { Mereness }\end{array}$ & $\begin{array}{l}\text { Thres } \\
\text { Gall } \\
\text { Stre }\end{array}$ & \\
\hline $\begin{array}{l}870 \\
898 \\
895 \\
811\end{array}$ & $\begin{array}{c}<1^{\circ} \\
1 \\
2 \\
<1^{\circ}\end{array}$ & $\begin{array}{c}<1 \\
14 \\
14 \\
<1\end{array}$ \\
\hline
\end{tabular}

- Gales al lowest slicss avaluated 


\section{$\left(\begin{array}{c}\text { STANDARD } \\ 316\end{array}\right)$}

\section{Type Analysis}

Description
Carbon ............. 0.03\% max. Manganese ......... 2.00\% max. Phosphorus ........ 0.045\% max. Sulfur ........... $0.030 \% \max$. Silicon............... 1.00\% max.

Projoct 700 Slainless Type $316 \mathrm{~L}$ is an improved machining version of convontional Type 316L Users report this grade has oflorod signilicantly improved machinability characleristics, including faster machining spoeds. longer tool life and improved linishes.

In this low-carbon austonilic alloy. control of carbon lo a maximum of 0.0346 has been shown to minimize

\section{Appllcations}

\section{Corrosion Resistance}

Project 70 Stainless Type 316L has found application in paper pulp handling -quipment, process equipment for producing pholographic chemicals, ink,

Prolect 70 Stainless Type 310L has been usod in sullits pulp mills to resist corrusion by sullurous acld compounds. Dus to its euperior corroslon resislance. ito uso has been extended to handling many of the chemicals usod by chemical procese industries.
Chromium ......... 16.00118.00\%

Nickel . . . . . . . . . 10.00/14.00\%

Molybdenum ......... 2.00/3.00\%

Iron ................ Balance

carbide precipitallon during welding. Customers report the uso of this steel in the as - welded condition in a variely of corrosive applications.

Containing molybdenum with increased percentages of nickol, this alloy displays highor tensile and creep strongths at elevaled temperatures and better corrooion resislunce than the cull. ventional 18.8 alloys.

$+\infty$

rayon, ,ubuer, textile bleaches and dyestulls as woll as various high temperature equipment applications.

This alloy is more resistant to pitting than conventional 18-8 alloys. For oplimum corrosion resistance, sur. laces must bo tree of scale and lorergn panicles. Finisned parts should be passivated.

\begin{tabular}{l}
\hline Scallng \\
\hline $\begin{array}{l}\text { Physlcal } \\
\text { Properties }\end{array}$
\end{tabular}

Heat Treatment

\section{Annoaling}

Heal to 1 BSO $/ 2050^{\circ} \mathrm{F}\left(1010 / 1121^{\circ} \mathrm{C}\right)$ and water quench. Brinell hardness approximaloly 150 .
Electrical resistivily (RT)

ohms $\mathrm{c} / \mathrm{mt} \ldots \ldots \ldots \ldots \ldots \ldots$. 445 microhm-mm .............. 740

Moan coefticient of thermal expansion $10-1 /{ }^{\circ} \mathrm{F}\left(32 / 1200^{\circ} \mathrm{F}\right) \ldots \ldots \ldots .10 .3$

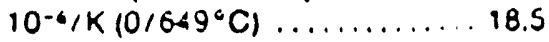

The sale acaling temperature for

Specilic gravity .............. 7.95

$\mathrm{lb} / \mathrm{cu}$ in $\ldots \ldots \ldots \ldots \ldots \ldots . \ldots .287$

$\mathrm{kg} / \mathrm{cum}$................ 7950

Btu/lb.nF $\left(32 / 212^{\circ} F\right) \ldots \ldots \ldots 0.12$

J/kg.K $\left(0 / 100^{\circ} \mathrm{C}\right) \ldots \ldots \ldots \ldots, 300$ 


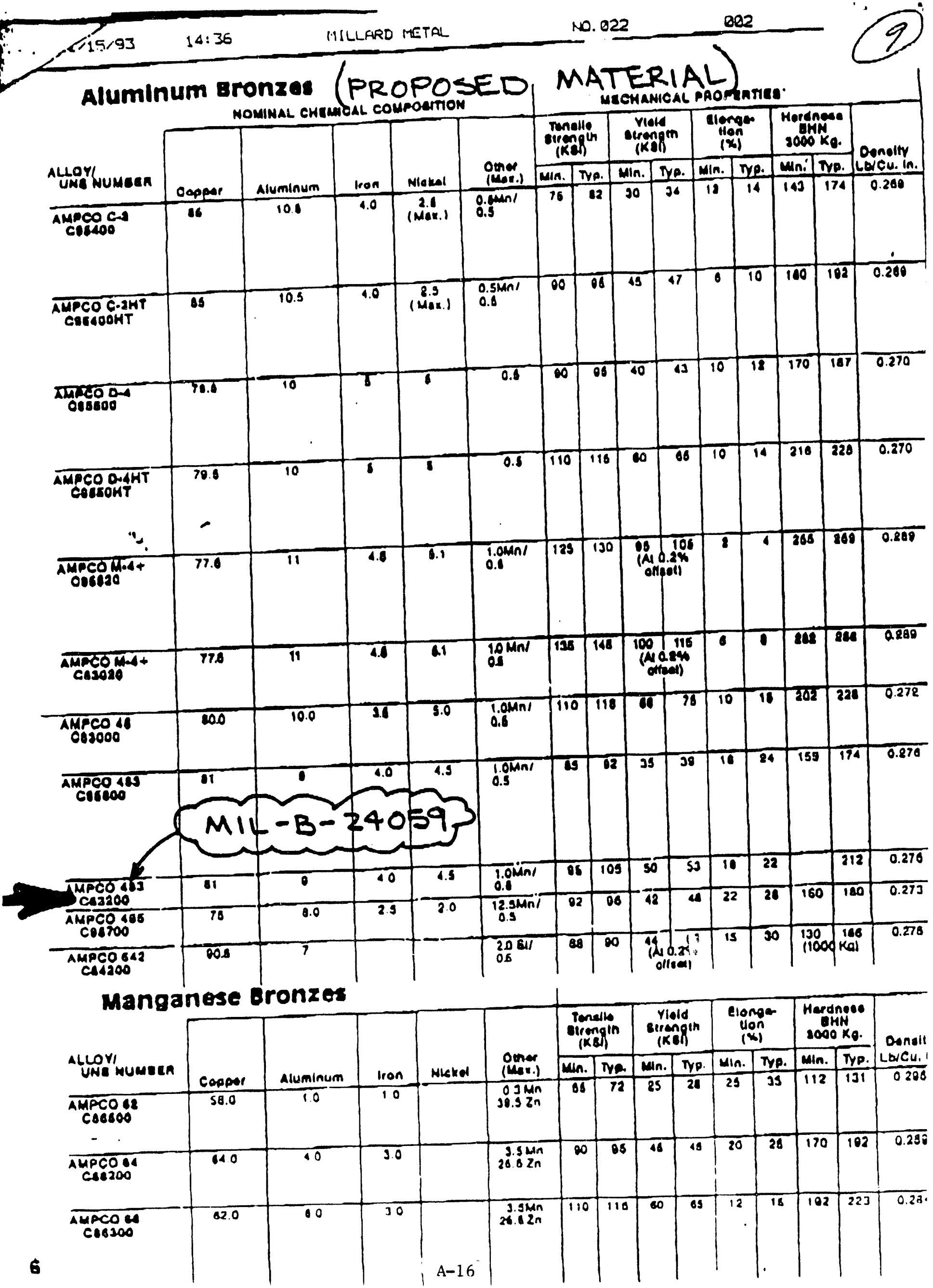



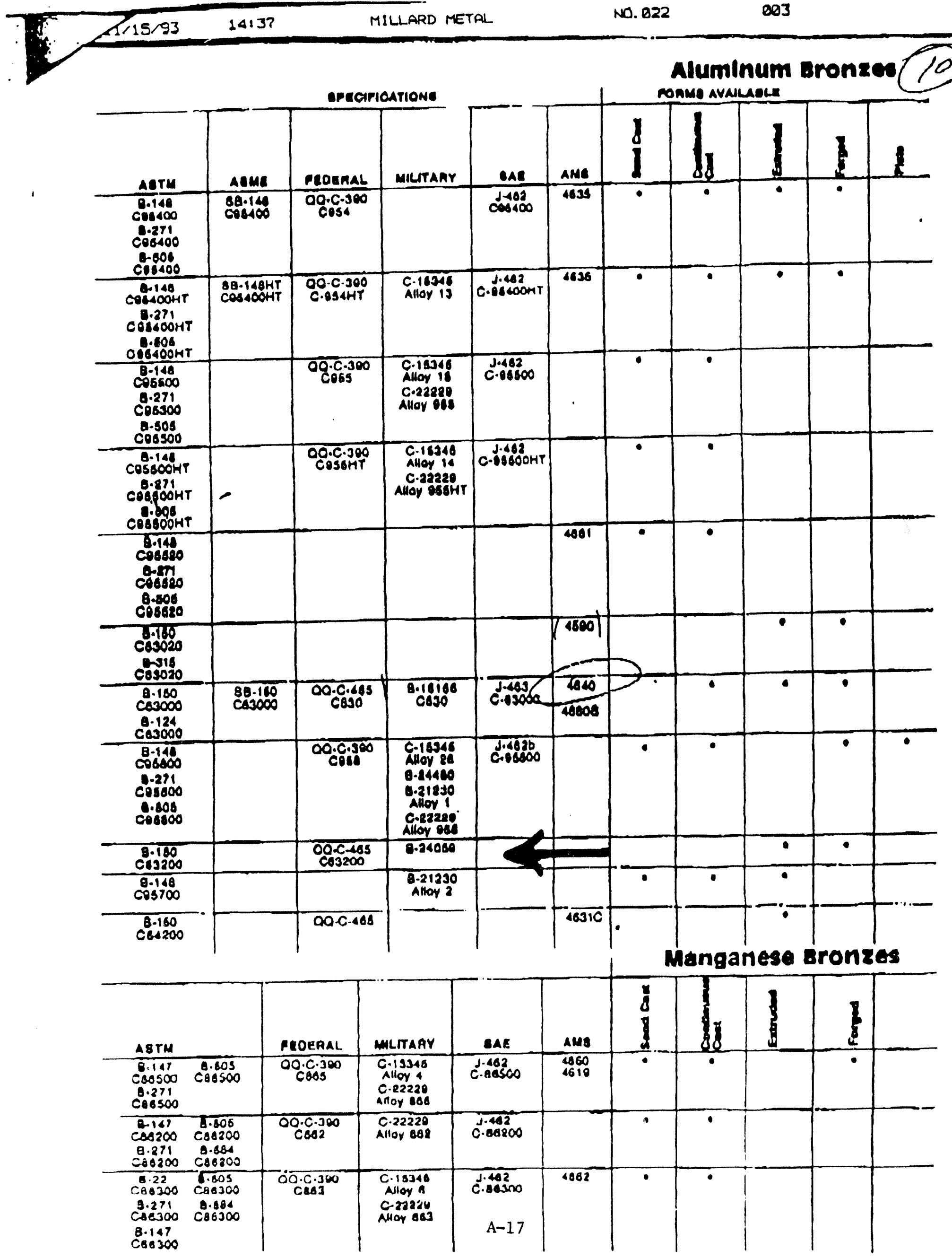


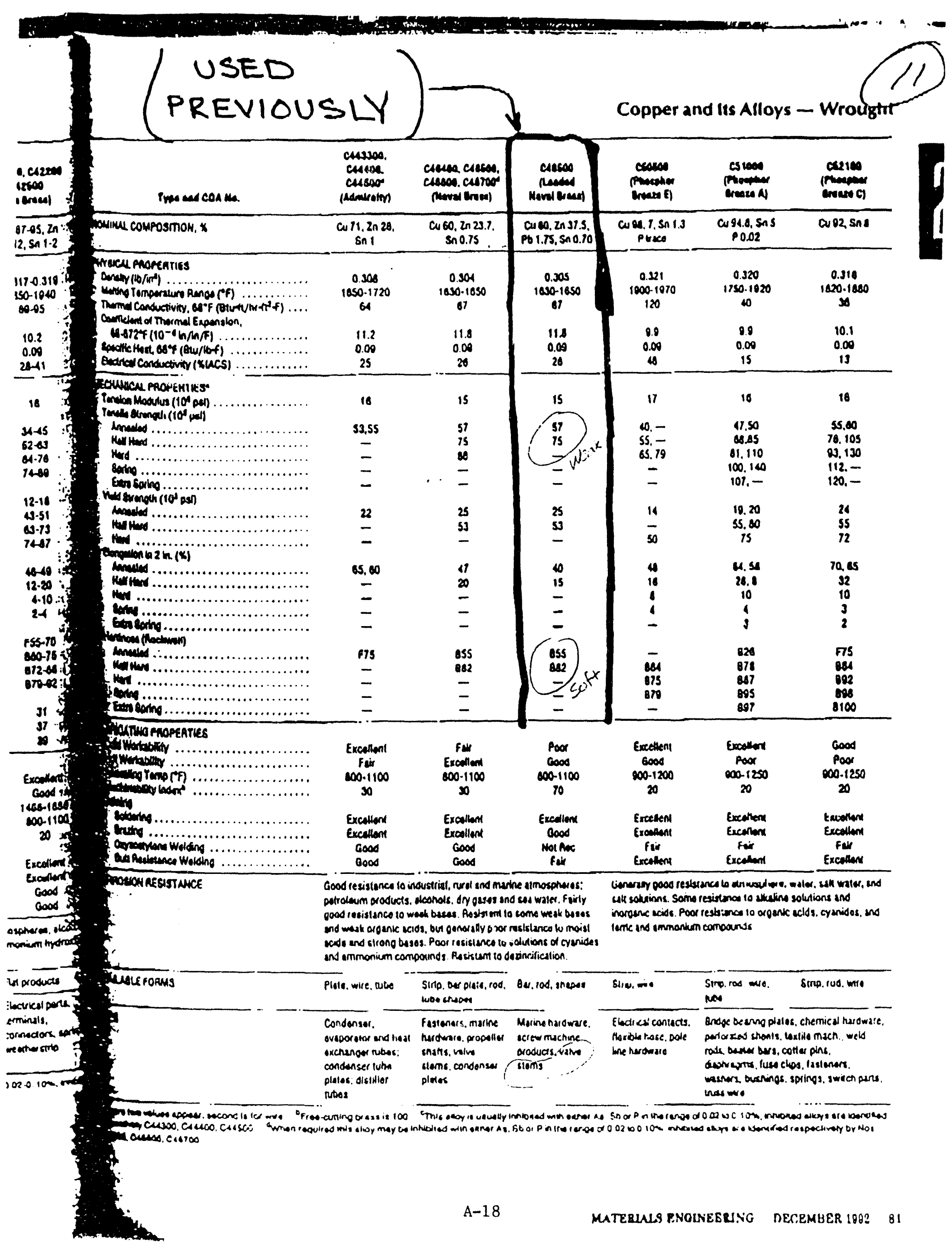


APPENDIX C

MATERIAL CERTIFICATES AND DESIGN OPTION DETAILS

FOR GALL-TOUGH AND BRONZE PISTONS 


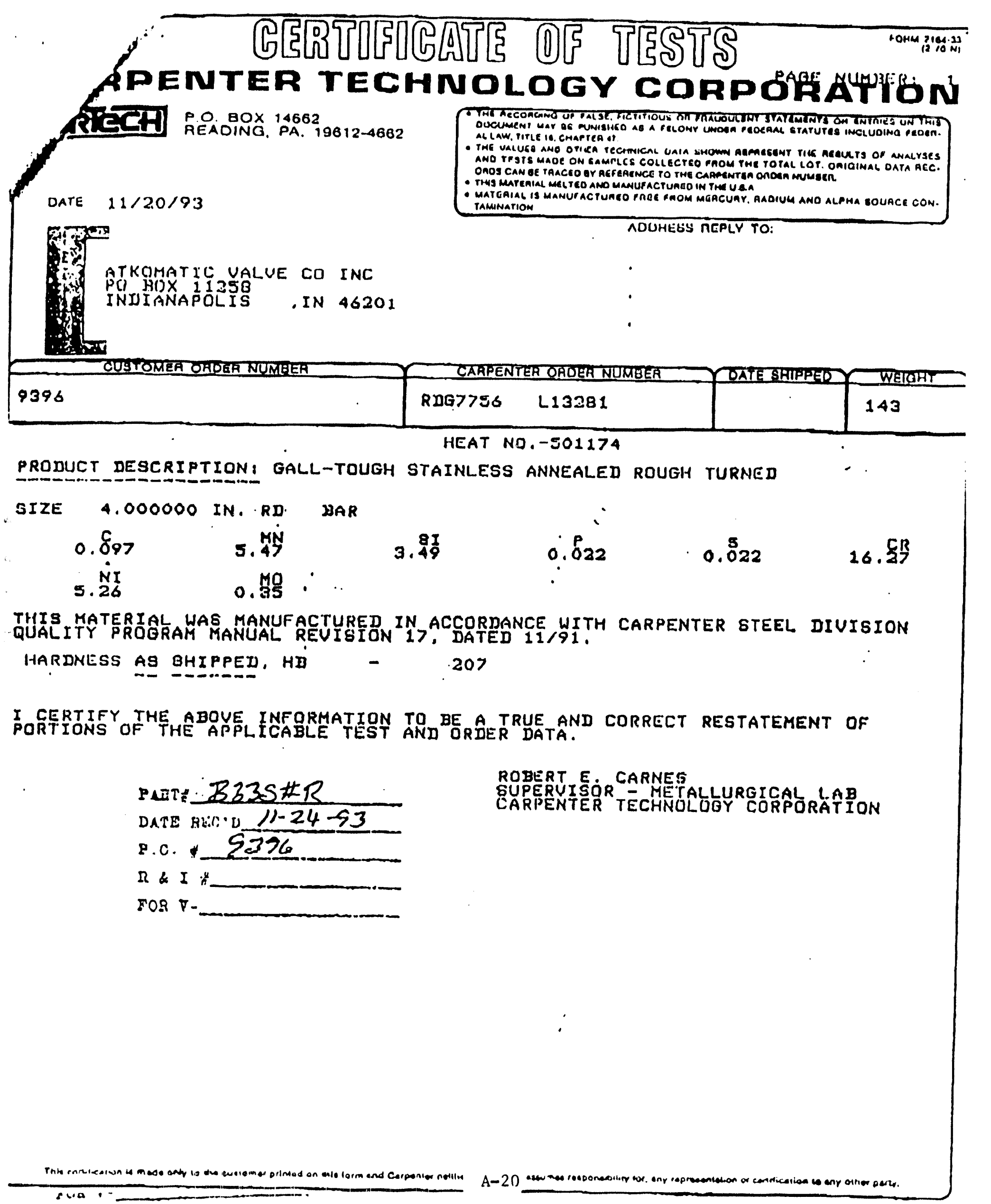




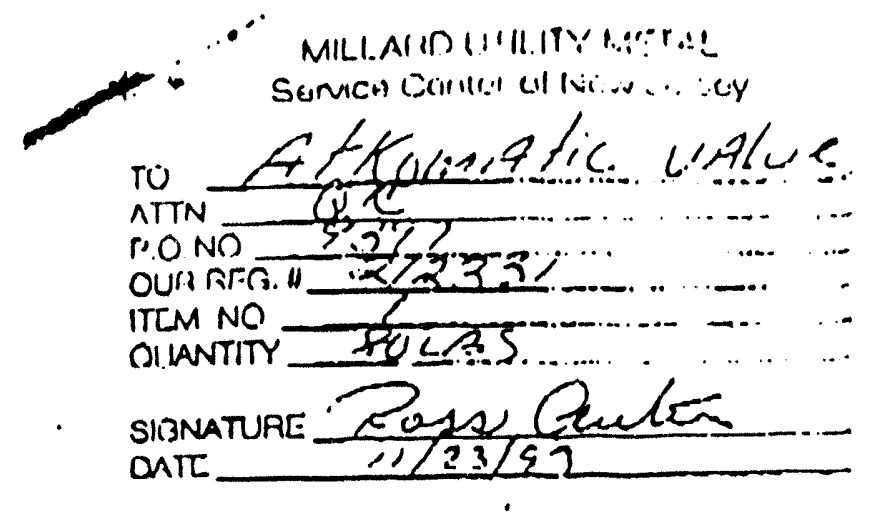

MATERIAL CERTIFICATION

DATE: NOVEMBER 17,1993

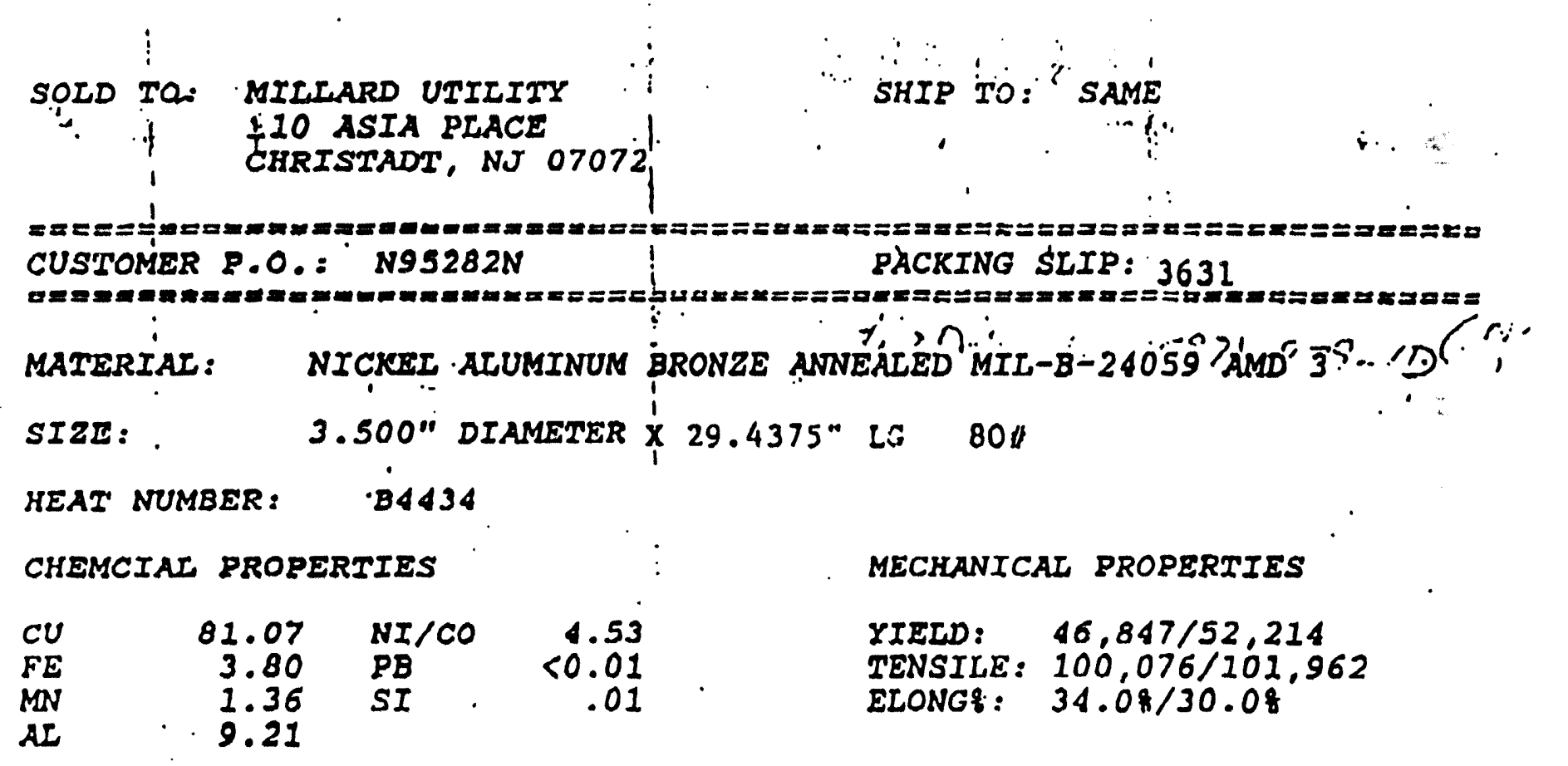

\section{MATERIAL FREE FROM MERCURY CONTAMINATION}

WE CERTIFY THAT THE CHEMICAL ANALYSIS AND PHYSICAL TEST RESULTS APPLYING ON THE ABOVE ORDER NUMBER ARE CORRECT AND TRUE.
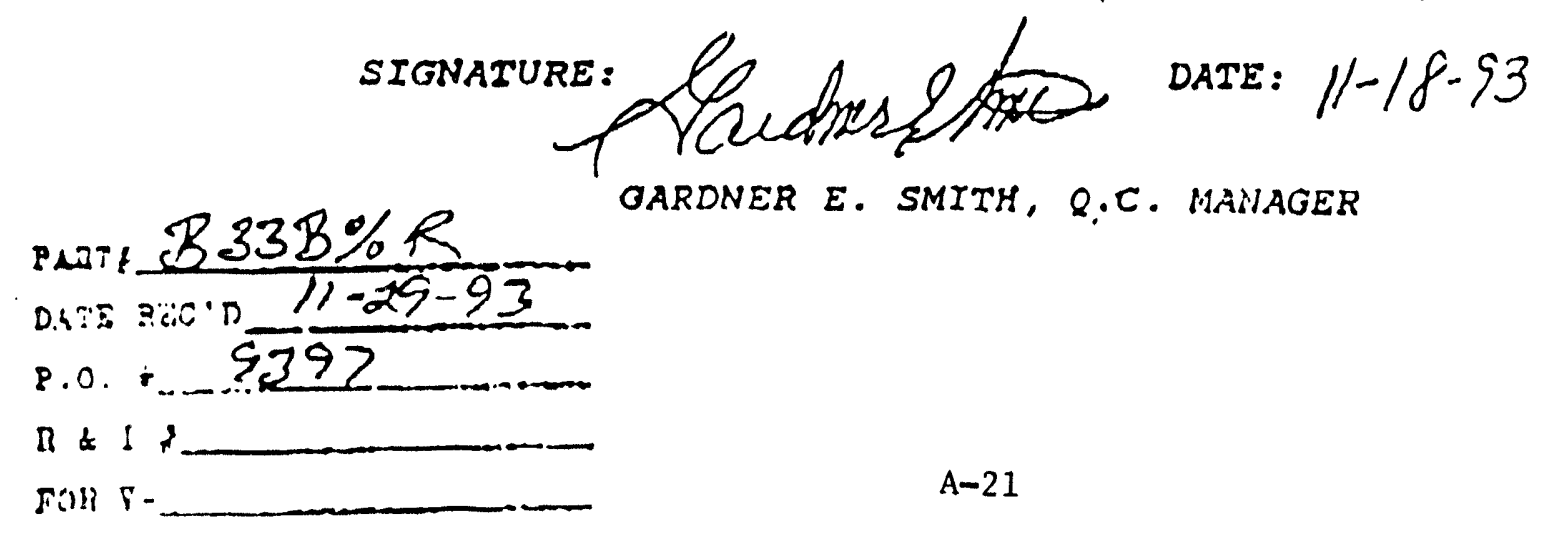


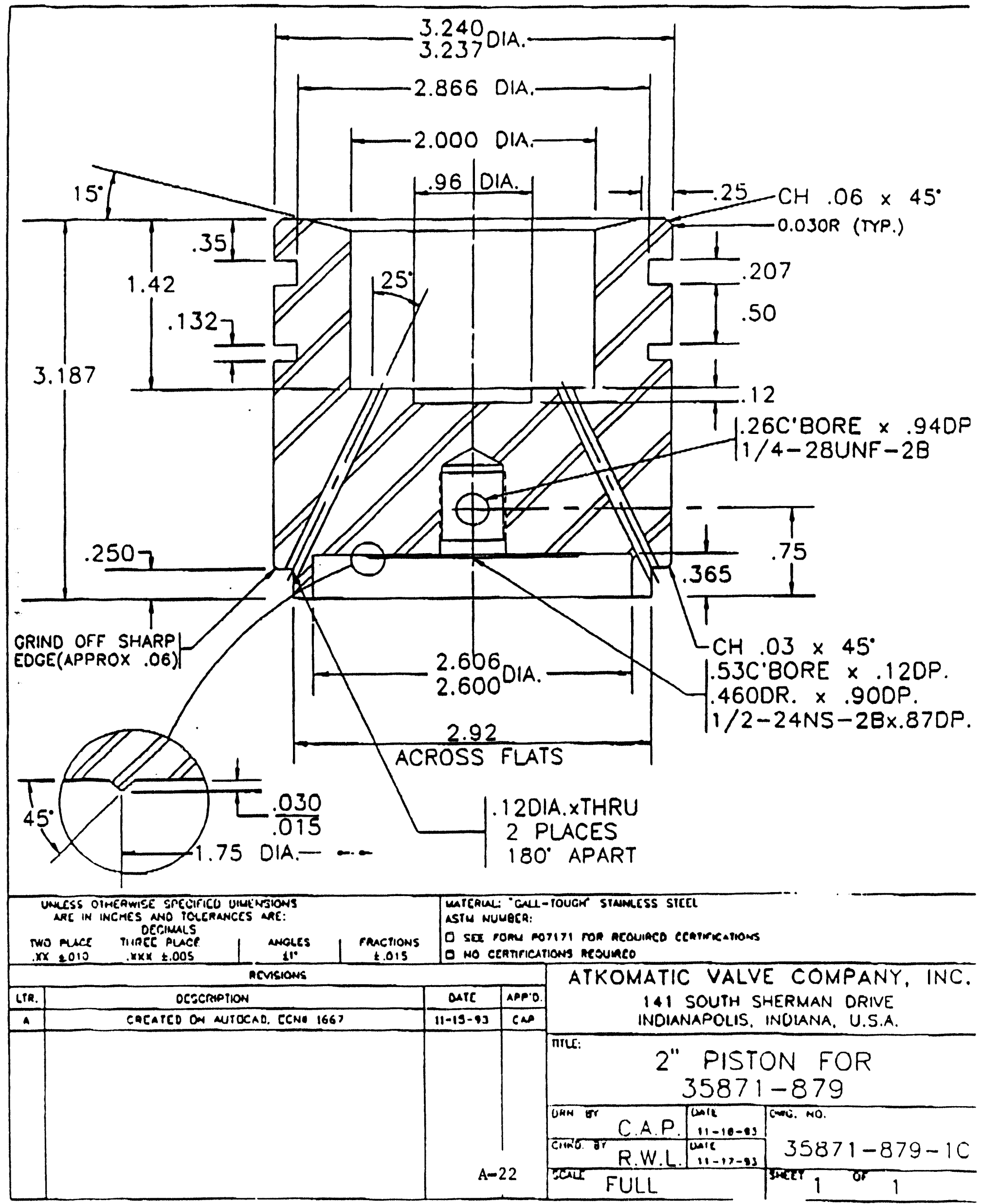




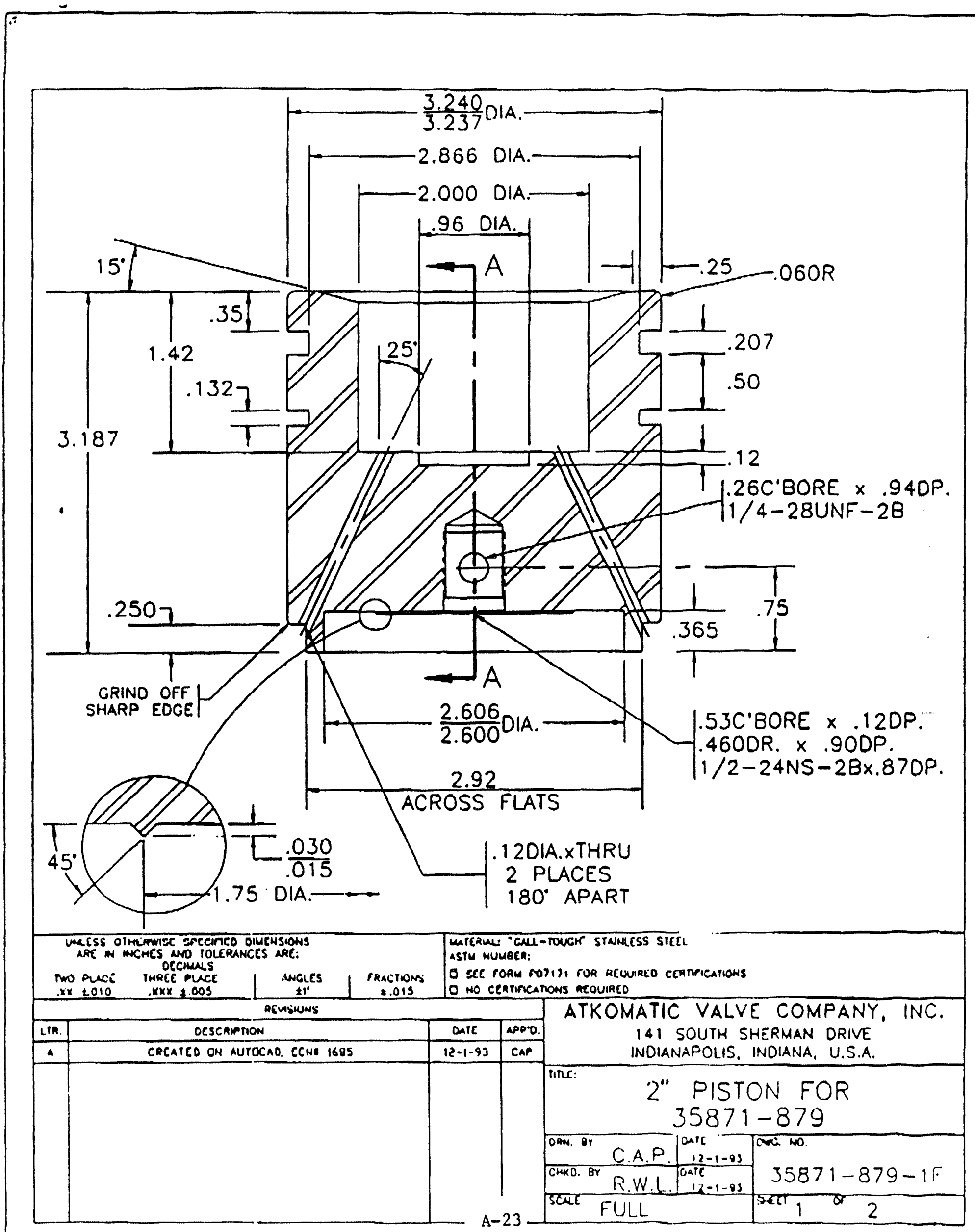




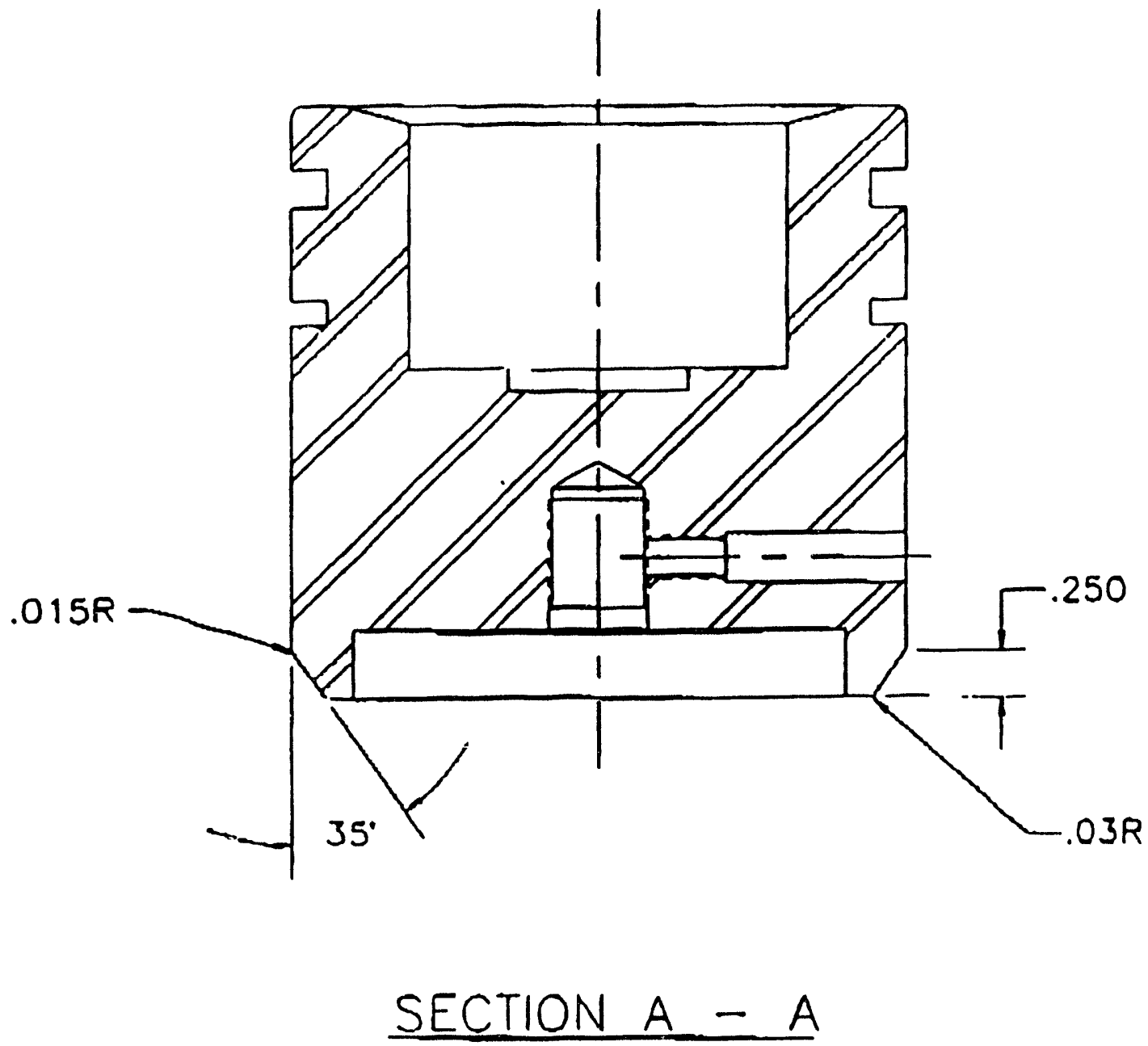

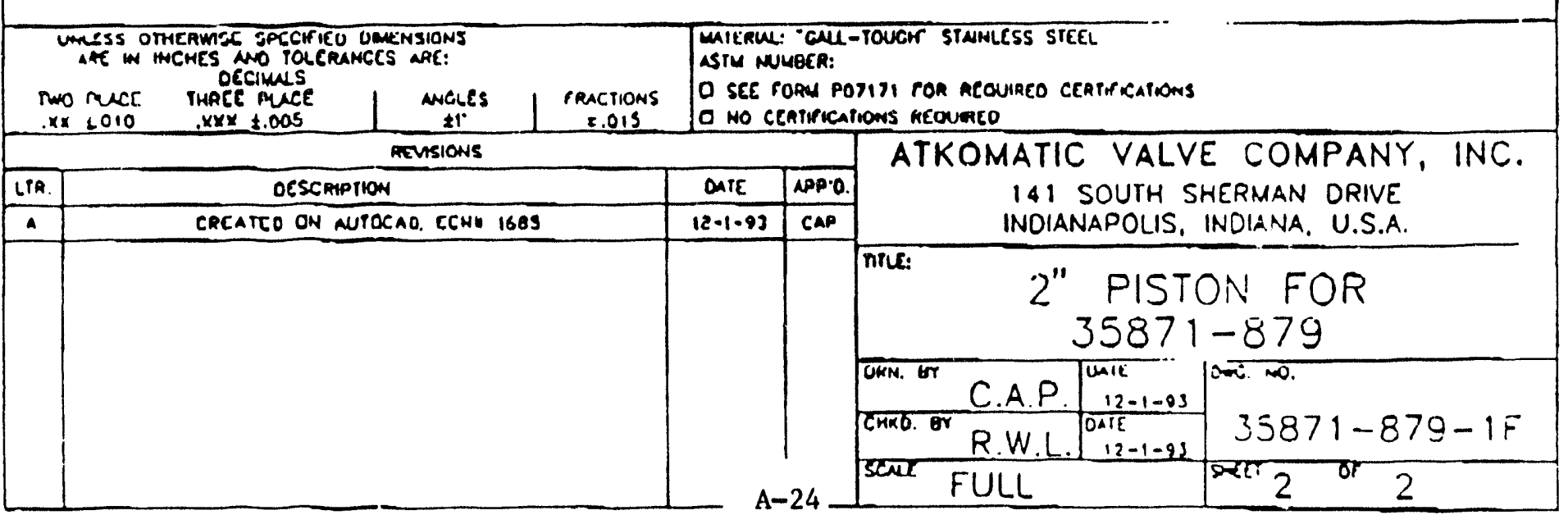




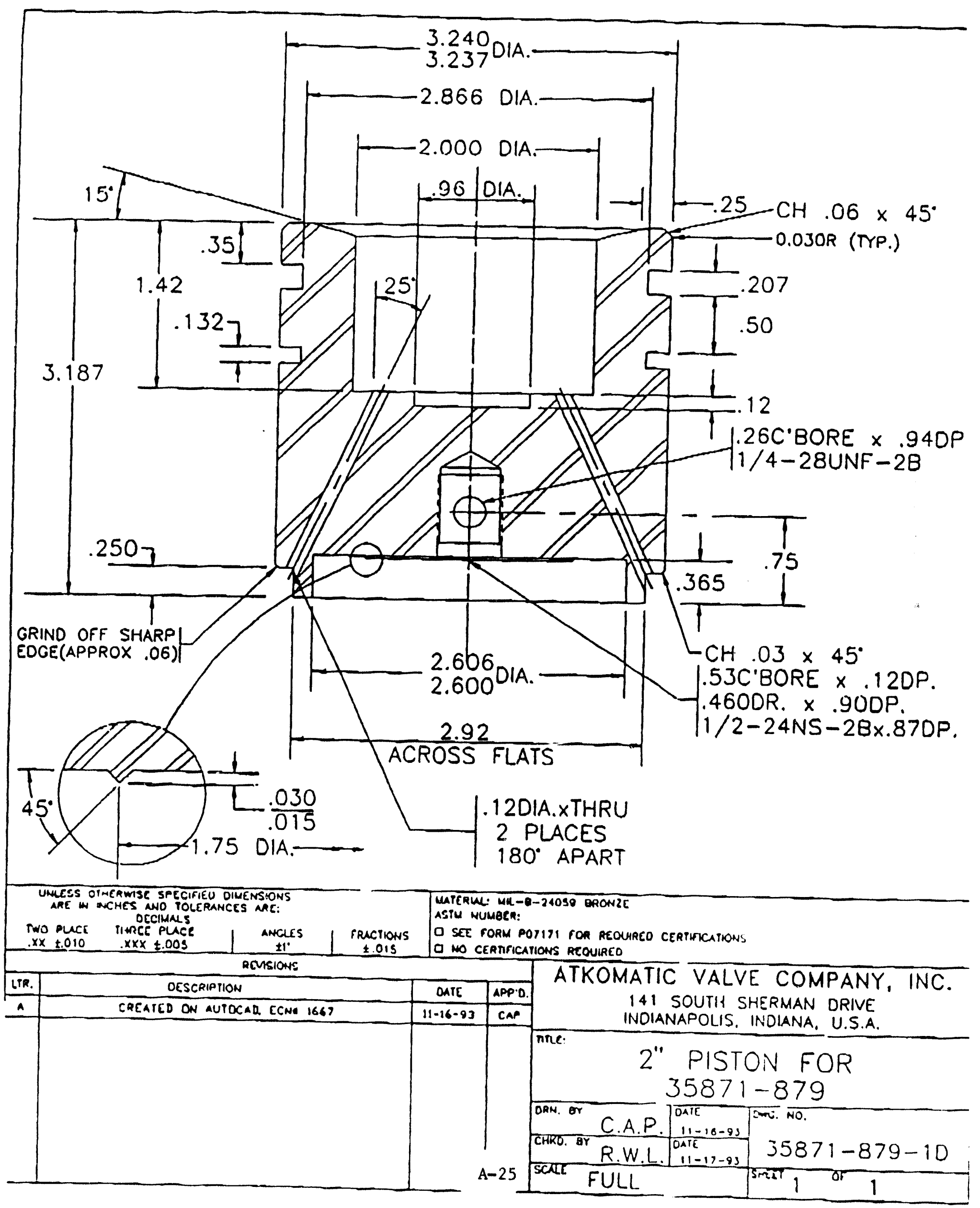




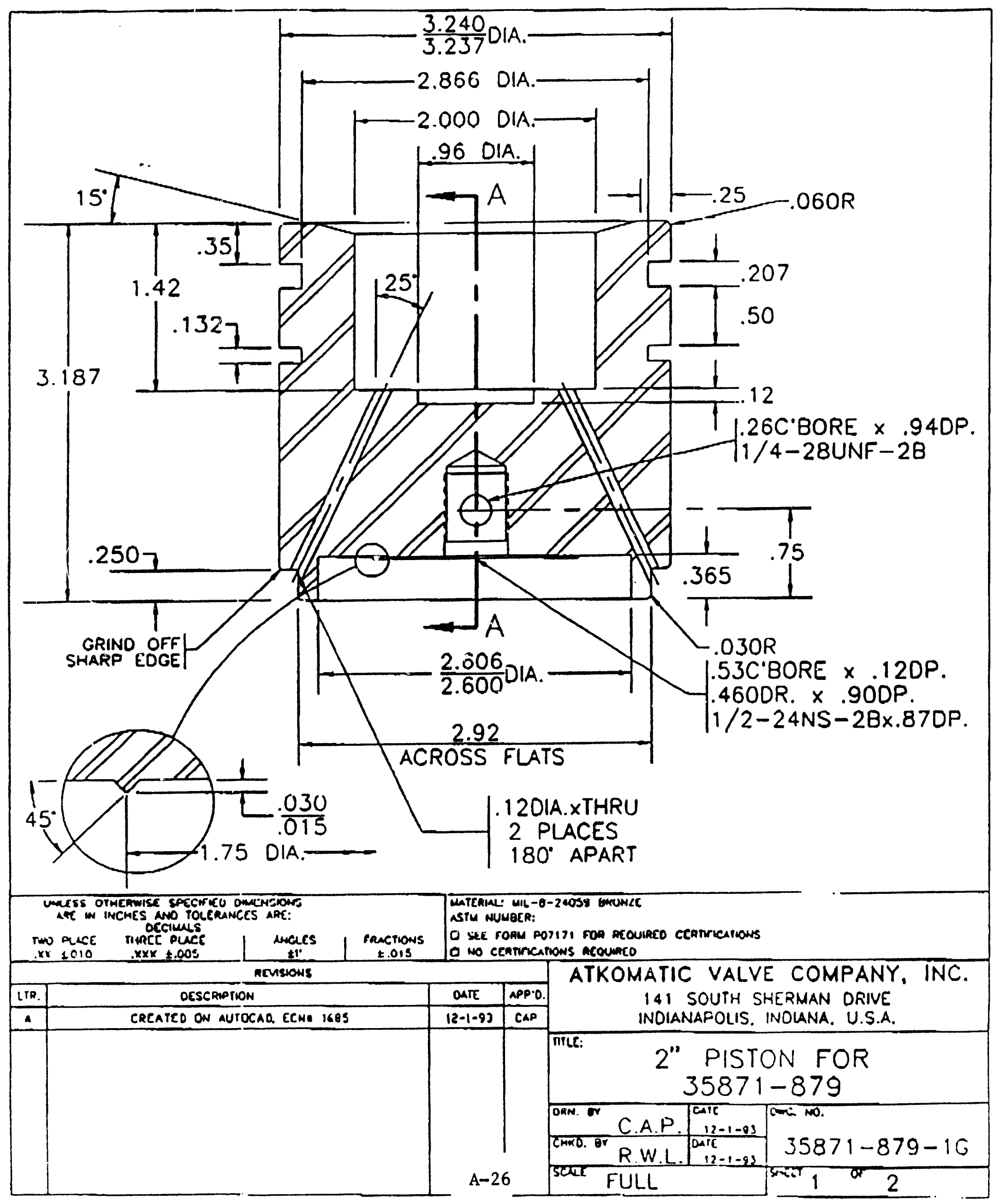




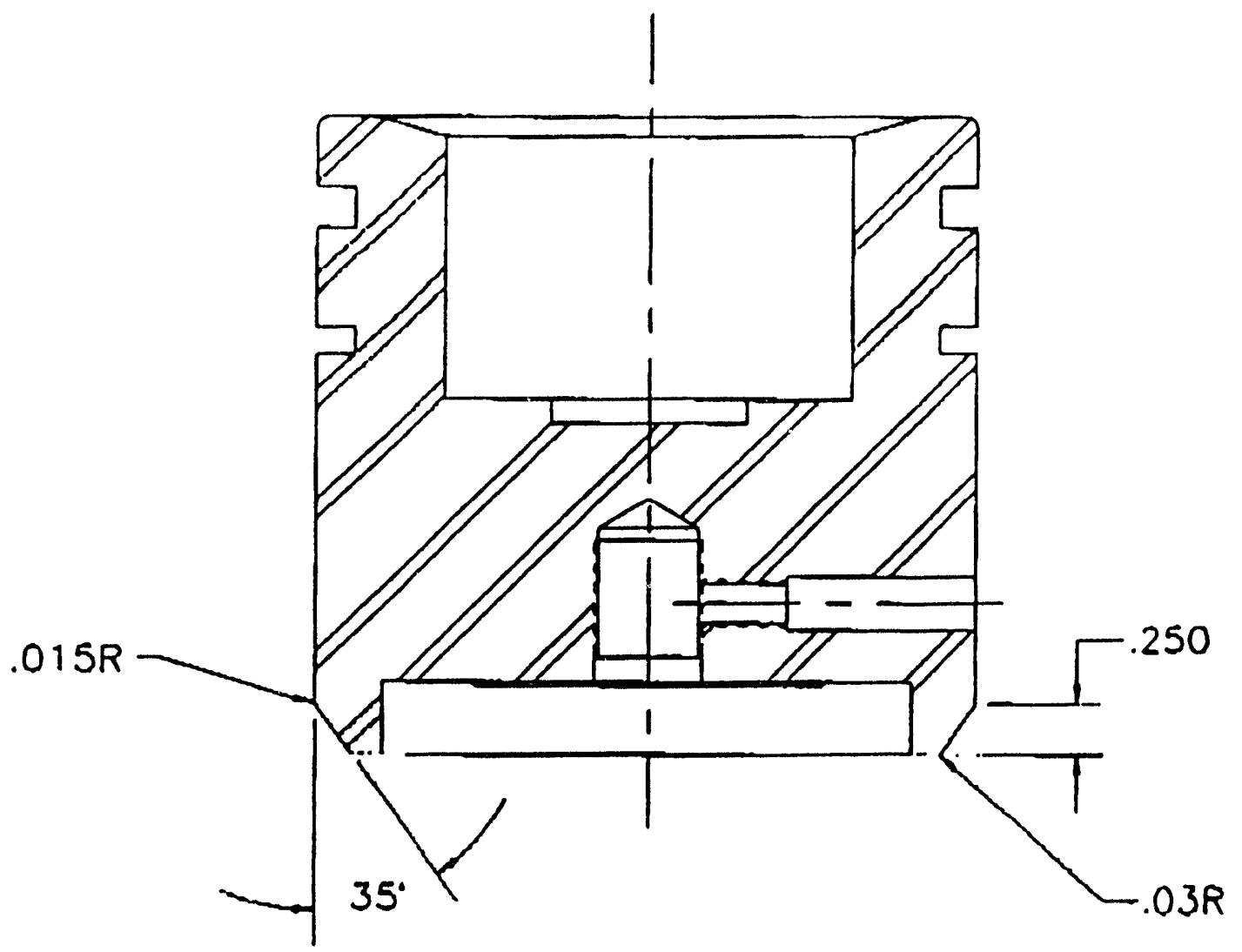

SECTION A - A

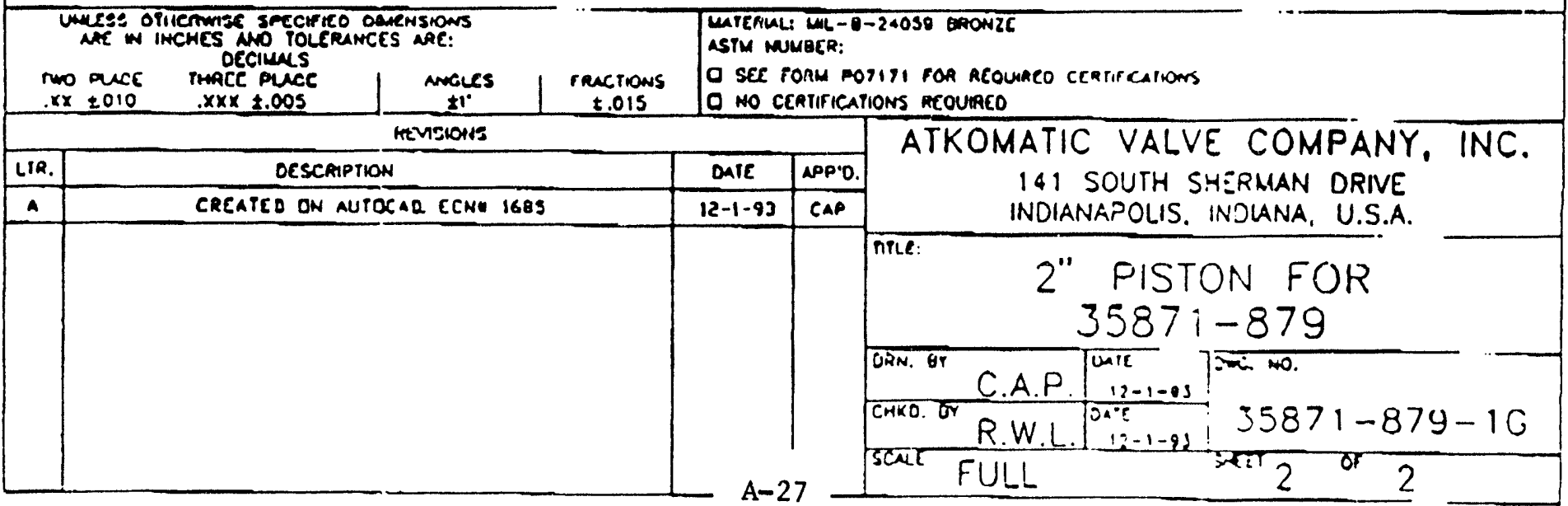




\section{APPENDIX B}

Characterization of the Clay Bonded Silicon Carbide

Candle Filters after 227 Hours of CFBC Operation

at the Karhula/Ahlstrom Facility

$B-1$ 
CHARACTERIZATION OF THE CLAY BONDED SILICON CARBIDE CANDLE FILTERS AFTER 227 HOURS OF CFBC OPERATION

M. A. Alvin

January 4, 1894

Introduction

Twenty-one clay bonded silicon carbide (seven Schumacher Dia Schumalith F40 and fourteen Pall Vitropore 442T filters), and ninety-one alumina/mullite candles were utilized in the circulating fluidized-bed combustion (CFBC) test facility at Karhula, Finland during testing between Weeks 18-20 and Weeks 21-23. Figure 1 illustrates the candle filter identification numbers and their location within the top, middle, and bottom plenums or cluster arrays in the Westinghouse Advanced Particulate (APF) system. Note that the inner ring of candle filters in the top cluster were removed (i.e., blanked off) during this segment of testing, leaving only the outer candle filters available for use.

During the Week 18-23 test period, the Westinghouse APF system was operated for a period of 227 hours at temperatures of $900^{\circ} \mathrm{C}$ with fines generated from Kentucky and Newland coal and Wilbur dolomite and Tsukumi limestone. Testing of the twenty-one, as-manufactured, clay bonded silicon carbide candles was initiated in this test segment. The ninety-one alumina/mullite candles had previously been exposed to the CFBC gas environment for a period of 489 hours, and therefore at test termination during Week 23, the alumina/mullite filters had acquired a total of 716 hours of operation at CFBC process conditions.

Although all twenty-one of the clay bonded silicon carbide candle filters remained intact during the 227 hours of CPBC operation, ten of the alumina/mullite candles which were positioned in the botton plenum of the Westinghouse APF experienced failure. Pailure was attributed to the shifting of the bottom shroud contour, and subsequent ash bridging between candles and the shroud in this area of the 


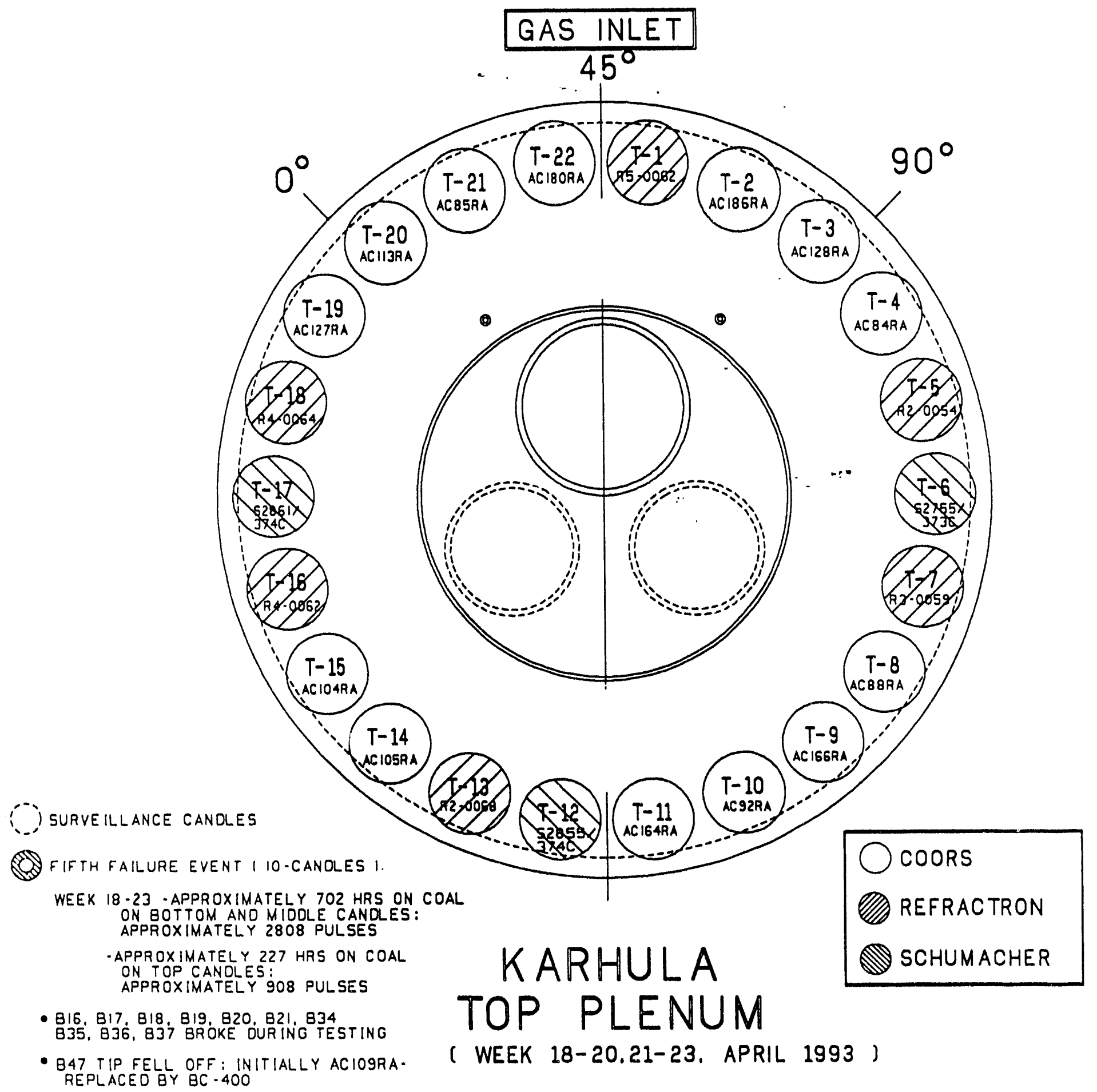

D.135.NAATI 


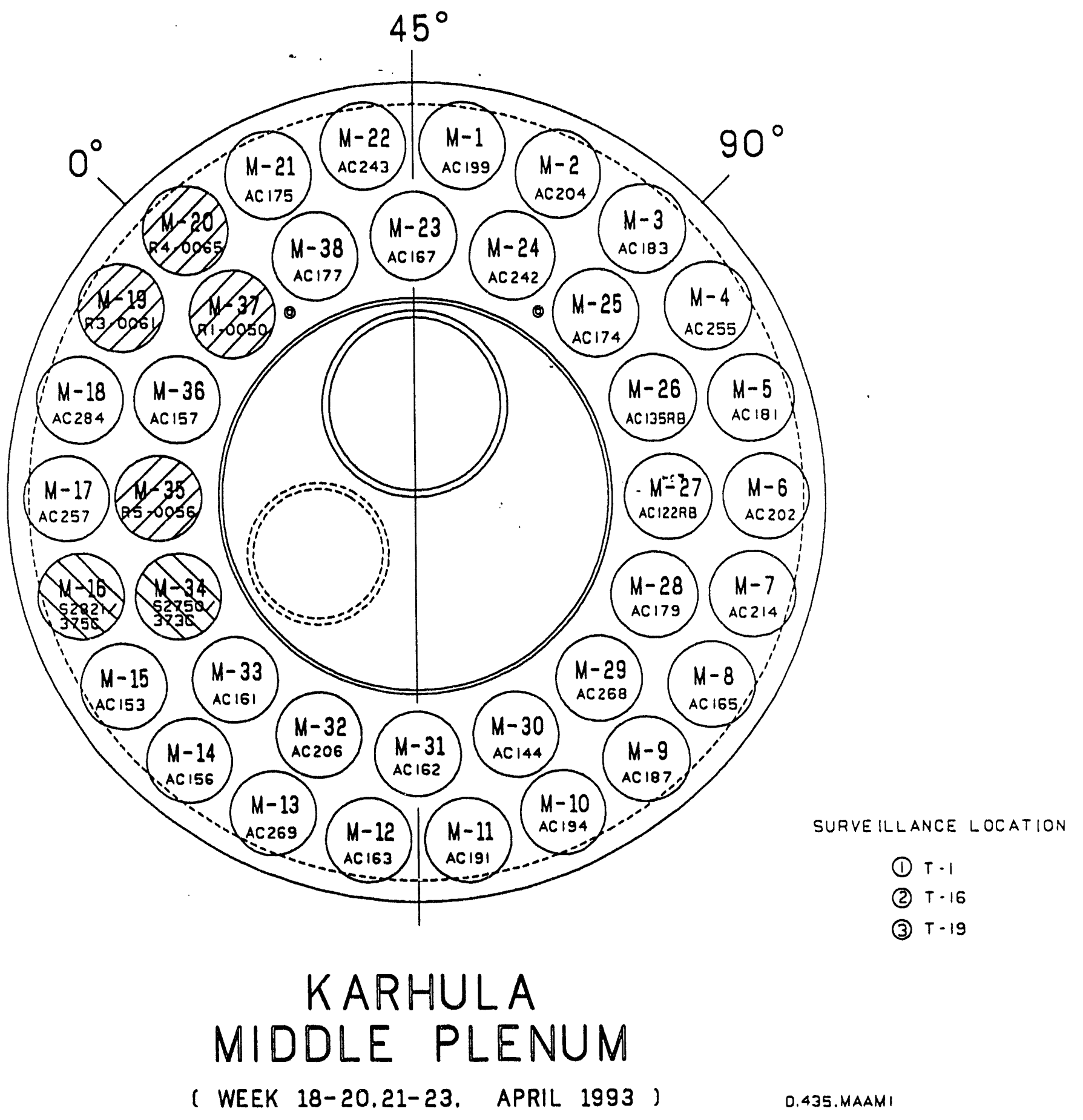

Figure 1b - Candle Filter Identification And Location Within The Westinghouse Advance Particulate Filtration System In Karhula, Finland (Weeks 18-20 and Weeks 21-23) 


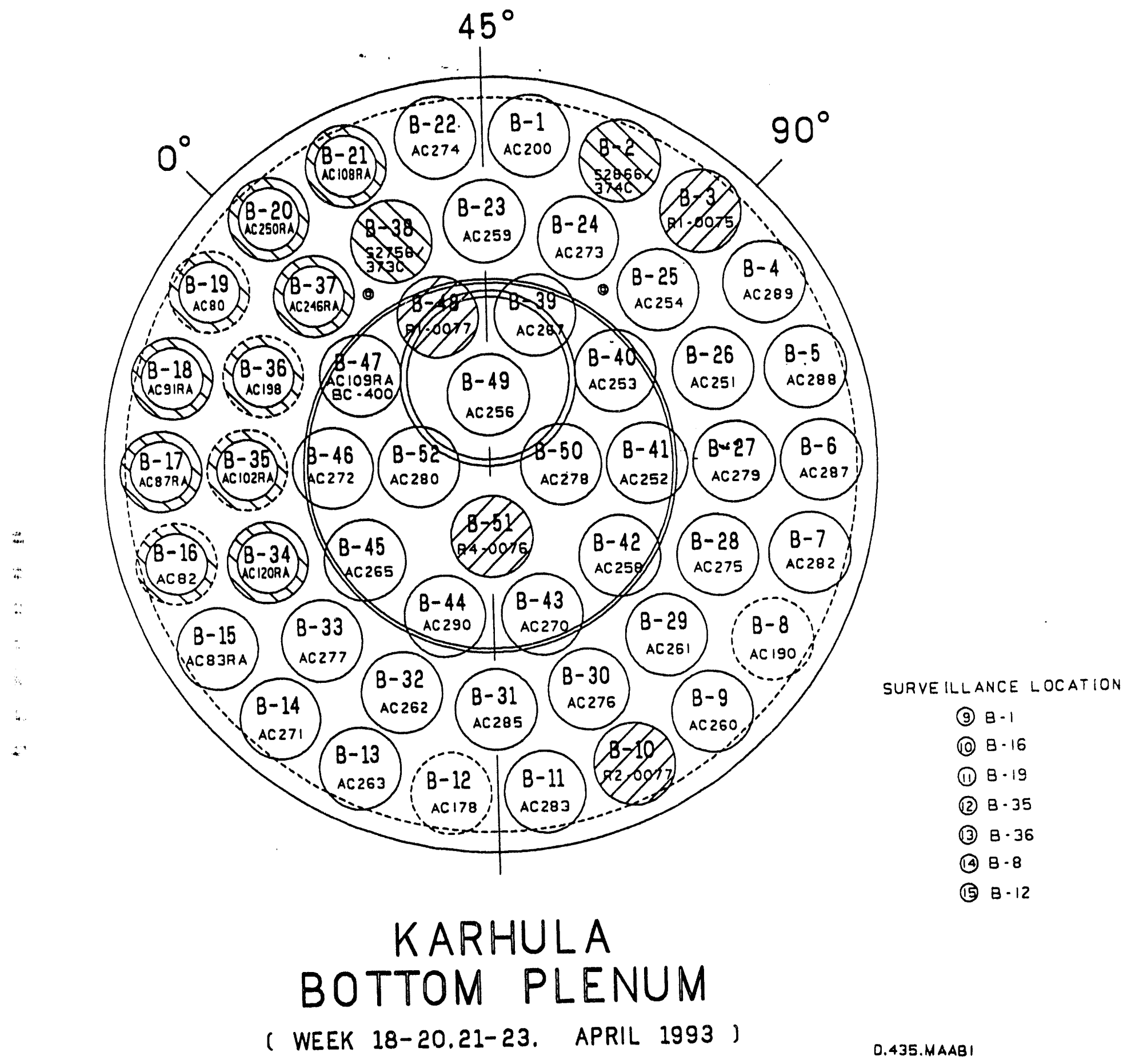

Figure 1c - Candle Filter Identification And Location Within The Westinghouse Advance Particulate Filtration System In Karhula, Finland (Weeks 18-20 and Weeks 21-23) 
Westinghouse APF ressel. Since a breech or failure of the ten alumina/mullite filters had occurred, ash fines were permitted to enter the clean side of the APF, and subsequently be redistributed along the remaining ID surfaces of the intact, as well as fractured candle filters during pulse gas cleaning. As a result, dust penetration along the candle filter ID surfaces was evident during both borescope and visual inspection. Figures 2 and 3 indicate that ash fines penetrate to depths of 2-2.5 mm into the ID surfaces of either the $15 \mathrm{~mm}$ wall clay bonded silicon carbide Schumacher Dia Schumalith F40 candle, or the $10 \mathrm{~mm}$ wall clay bonded silicon carbide Pall Vitropore $442 \mathrm{~T}$ candle.

This report focuses on the material characterization results for the clay bonded silicon carbide candle filters which were removed from the Westinghouse Advanced Particulate Filtration system after 227 hours of operation in the CFBC gas environment. Candle filters which were destructively characterized in this effort included a Schumacher Dia Schumalith F40 candle designated as S2855/374C which had been positioned in the Westinghouse APF cluster array location T12, and a Pall Vitropore 442T candle designated as B3-0061 which had been positioned in location M19. Characterization of these filters included:

- Room temperature and hot strength $\left(900^{\circ} \mathrm{C}\right)$ analysis (i.e., Cring compression and tension)

- Burst strength analysis and determination of Young's Modulus

- Scanning electron microscopy/energy dispersive $x$-ray analysis (SEM/EDAX)

- Gravimetric leaching and qualitative $x$-ray analysis (XRD).

Similar characterization of as-manufactured Schunacher and $\mathrm{Pall}$ candle filters (i.e., S4828/315C and R1-0061, respectively) was performed in order to provide baseline information regarding the rarious material and 


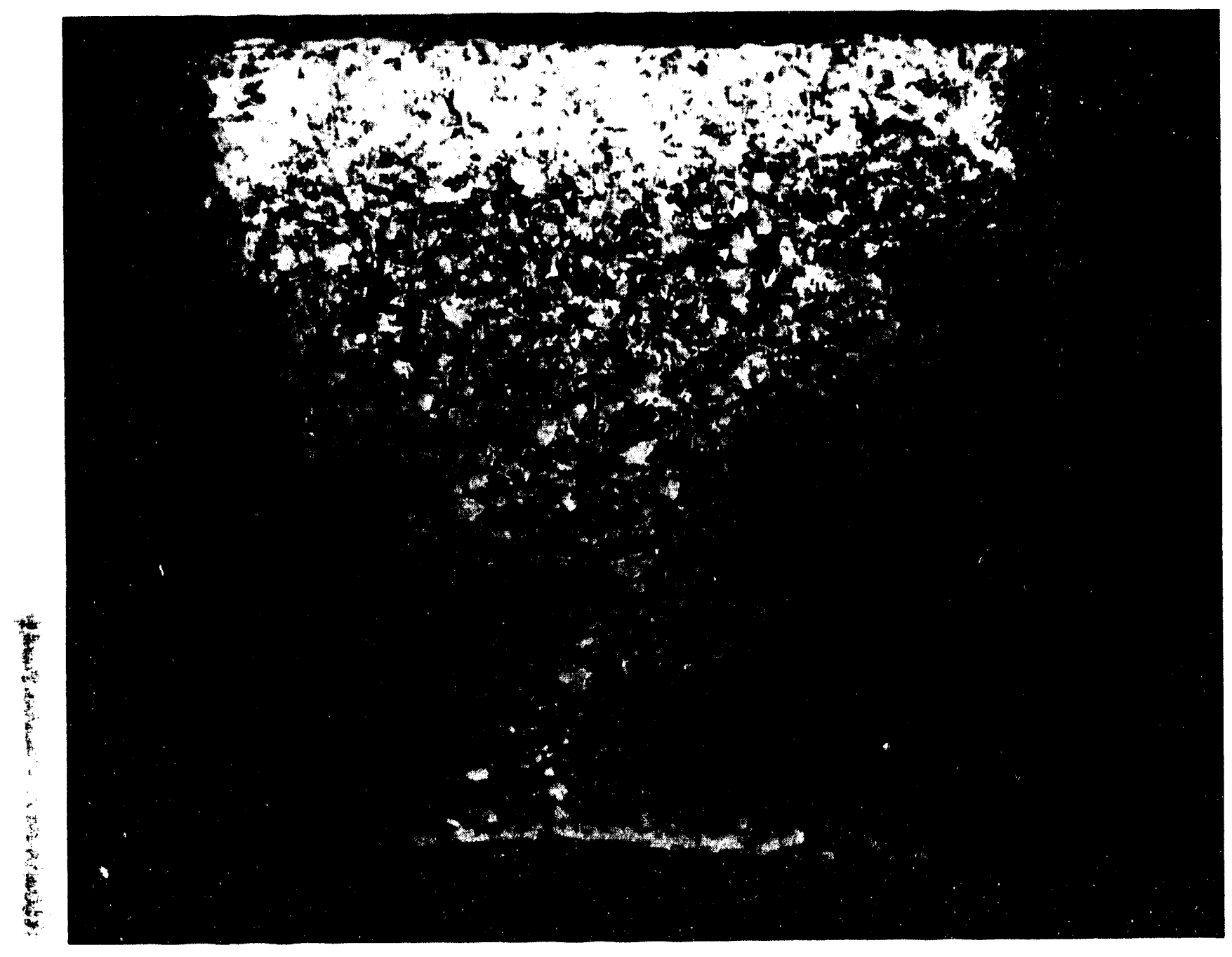

Figure 2 - Depth of Fines Penetration Along The ID Surface of A Schumacher Dia Schumalith F40 Candle Filter Designated As S2855/374C (T12) 


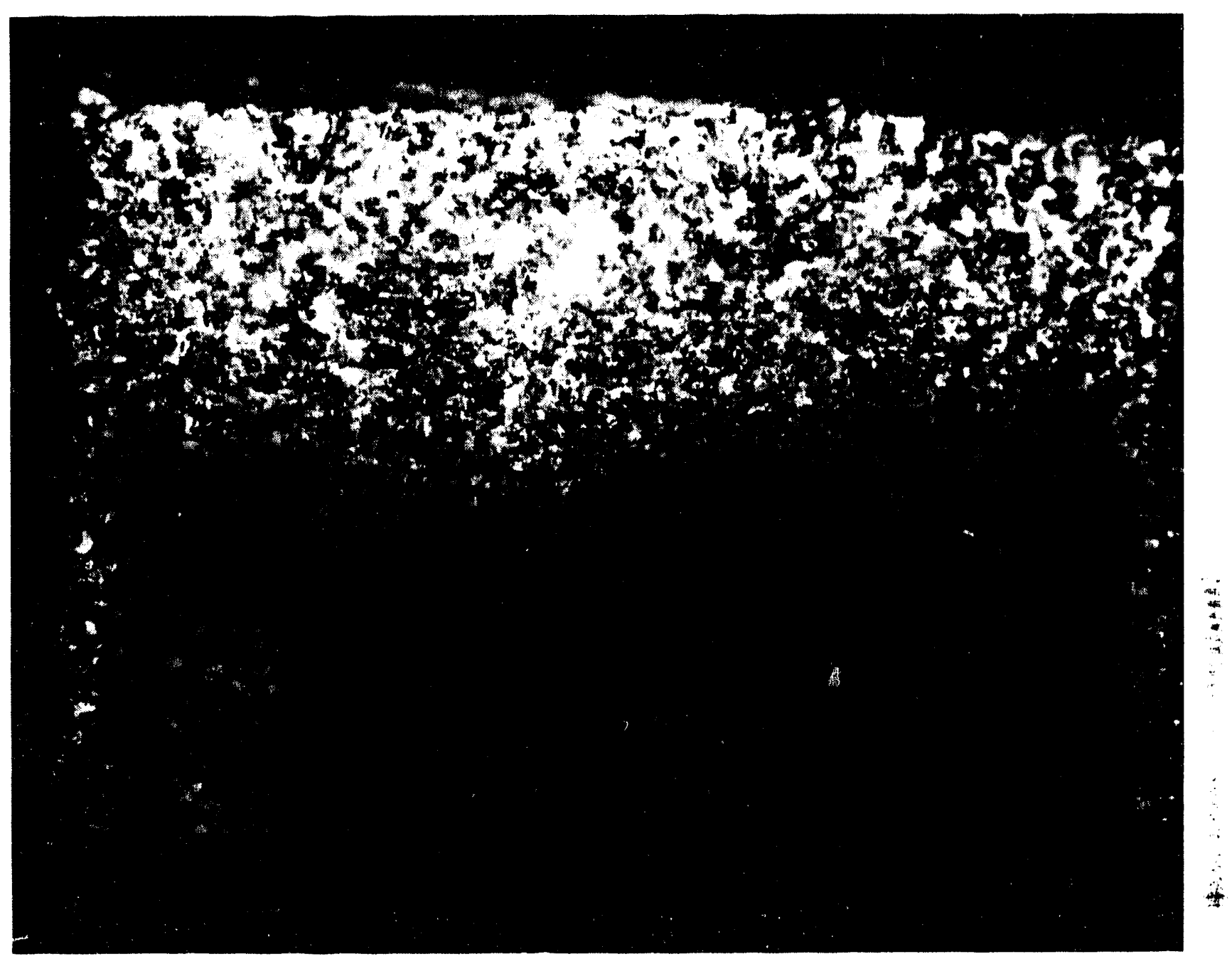

Figure 3 - Depth of Fines Penetration Along The ID Surface of A Pall Vitropore 442T Candle Filter Designated As R3-0061 (M19) 
compositional properties of both clay bonded silicon carbide matrices. The characterisation results for both the as-manufactured and fieldtested Schumacher and Pall candle filters are provided in the following sections. Similar efforts were also conducted on the alumina/mullite candle filters which were exposed to the additional 227 hours of service during the CFBC test segment in Weeks 18-20 and Weeks 21-23. The results of the alumina/mullite filter characterisation will be provided in a subsequent Quarterly Report.

Katerial Strength Characterization

Table 1 summarizes the room temperature and $900^{\circ} \mathrm{C}$ process temperature strength data for both the as-manufactured and the 227 hour CFBC-exposed Schumacher Dia Schumalith F40 and Pall Vitropore 442T candle filters. Both filter materials experienced a loss of strength after 227 hours of operation in the $900^{\circ} \mathrm{C}$ CFBC gas environment. The strength data of the Pall Vitropore 442T candle filters exceed those of the Schumacher Dia Schumalith F40 matrix with the exception of the Schumacher Dia Schumalith candle ID surface strength at process operating temperatures. That is interesting to note in these data is that the ID surface of the Schumacher Dia Schumalith F40 matrix appears to be significantly stronger than its OD surface. A nearly comparable, but slightly stronger OD surface is typical of the Pall Vitropore 442T filter matrix. Although the Schumacher Dia Schumalith filter has a 15 mm wall thickness, while the Pall Vitropore $442 \mathrm{~T}$ candle has a $10 \mathrm{~mm}$ wall thickness, the differences observed in the OD vs ID candle filter strengths are attributed to the silicon carbide grain size and binder composition, as well as the individual vendor's manufacturing process and firing temperature profile which perhaps influence the bonding characteristics between adjacent silicon carbide grains within the various regions of the candle filter wall. 
TABLE 1

SUUYARY OF THE CLAY BONDED SILICON CARBIDE CANDLE FILTER YATERIAL STRENGTH

C-Ring Strength, psi

Candle ID Process Temp. Time, RT $\quad$ RT $960^{\circ} \mathrm{C} \quad 900^{\circ} \mathrm{C}$

- $\mathrm{C}$ Hrs. Comp. Tension Comp. Tension

Schumacher Dia Schumalith F40

$\begin{array}{lllllllll}\mathbf{S 4 8 2} / 3150 & --- & -- & -- & 1790 \pm 112 & 2308 \pm 275 & 1569 \pm 90 & 3158 \pm 271\end{array}$

$\begin{array}{lllllllll}\mathbf{S 2 8 5 5} / 3740 & \text { OFBC } & 900 & 227 & 824 & * 76 & 1268 \star 139 & 987 \star 87 & 2392 * 305\end{array}$ (T-12)

Pall Vitropore 442T

\begin{tabular}{|c|c|c|c|c|c|c|}
\hline $\begin{array}{r}\mathrm{R} 1-0081 \\
\mathrm{R} 3-0061 \\
(\mathrm{M}-19)\end{array}$ & $\overline{\text { CFBC }}$ & $\overline{80}$ & $\ddot{22}$ & $\begin{array}{l}3152 \approx 130 \\
2230 \approx 203\end{array}$ & $\begin{array}{l}2914 \approx 289 \\
1829 \neq 247\end{array}$ & 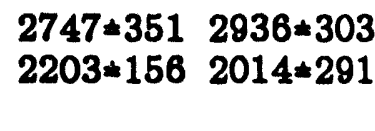 \\
\hline
\end{tabular}


Table 2 provides a summary of the percent strength retention for both filter elements after 227 hours of exposure in the $900^{\circ} \mathrm{C}$ CFBC gas environment. A greater strength reduction occurred along the OD surface of the Schumacher Dia Schumalith filter matrix, while a greater loss of material strength resulted along the ID surface of the Pall Vitropore 442T filter matrix. Thermal fatigue along the candle filter ID surface, as well as thermal/chemical degradation along the candle OD surfaces and through the filter walls are considered to be responsible for the loss of strength of the binder phase in both clay bonded silicon carbide filter materials.

Burst Strength And Young's Modulus Determination

Table 3 summarizes the results of the burst strength tests which were performed on 10 inch sections which were removed at comparable locations within both as-manufactured, as well as 227 hour exposed Schumacher Dia Schumalith and Pall Vitropore 442T candle filters. As with the C-ring compression and tension strength data previously discussed, the ultimate hoop stress of both filter elements decreases after exposure in the CFBC gas environment. Similarly Young's Modulus for both materials decreases during hot gas filtration in the CFBC gas environment.

Scanning Electron Microscopy/Energy Dispersive X-ray Analyses

Schumacher Dia Schumalith F40

Schumacher Dia Schumalith F40 clay bonded silicon carbide candle filters which were manufactured in 1992 were utilized in the hot gas filtration testing in the Karhula CPBC test facility. The morphology of the as-manufactured Schumacher Dia Schumalith filter matrix is shown in Figure 4. The binder phase which encapsulates the silicon carbide grains consists principally of a silica-enriched matrix, with minor contributions of alumina, as well as potassium, sodium, and 


\section{TABLE 2}

CANDLE FILTER PERCENT STRENGTH RETENTION

\begin{tabular}{lcccc} 
Matrix & $\begin{array}{c}\text { RT } \\
\text { Compression }\end{array}$ & $\begin{array}{c}\text { RT } \\
\text { Tension }\end{array}$ & $\begin{array}{c}900^{\circ} \mathrm{C} \\
\text { Compression }\end{array}$ & $\begin{array}{c}900^{\circ} \mathrm{C} \\
\text { Tension }\end{array}$ \\
\hline $\begin{array}{l}\text { Schumacher Dia } \\
\text { Schumalith F40 }\end{array}$ & 46.03 & 54.94 & 62.91 & 75.74 \\
$\begin{array}{l}\text { Pall Vitropore 442T } \\
\text { T0.75 }\end{array}$ & 62.76 & 80.20 & 68.60 \\
\hline
\end{tabular}


TABLE 3

BURST STRENGTH ANALYSIS AND YOUNG'S MODULUS

OF CFBC-EXXPSED CLAY BONDED SILICON CARBIDE CANDLE FILTERS

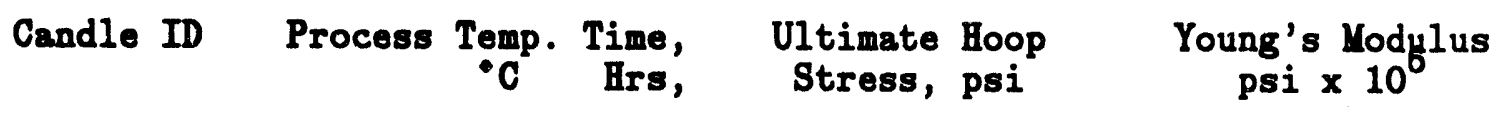

Schumacher Dia Schumalith F40

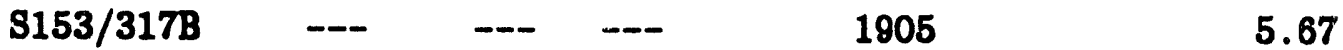

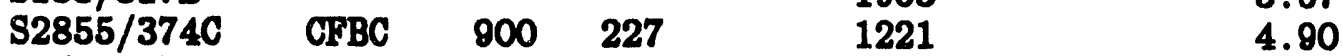

$(\mathrm{T}-12)$

Pall Vitropore $442 T$

$\begin{array}{llllll}\mathrm{R} 1-0061 & --- & --\overline{1} & --\overline{1} & 1816 & 8.04 \\ \mathrm{R} 3-0061 & \text { CFBC } & 900 & \mathbf{2 2 7} & 1186 & 5.98\end{array}$

(Y-19) 

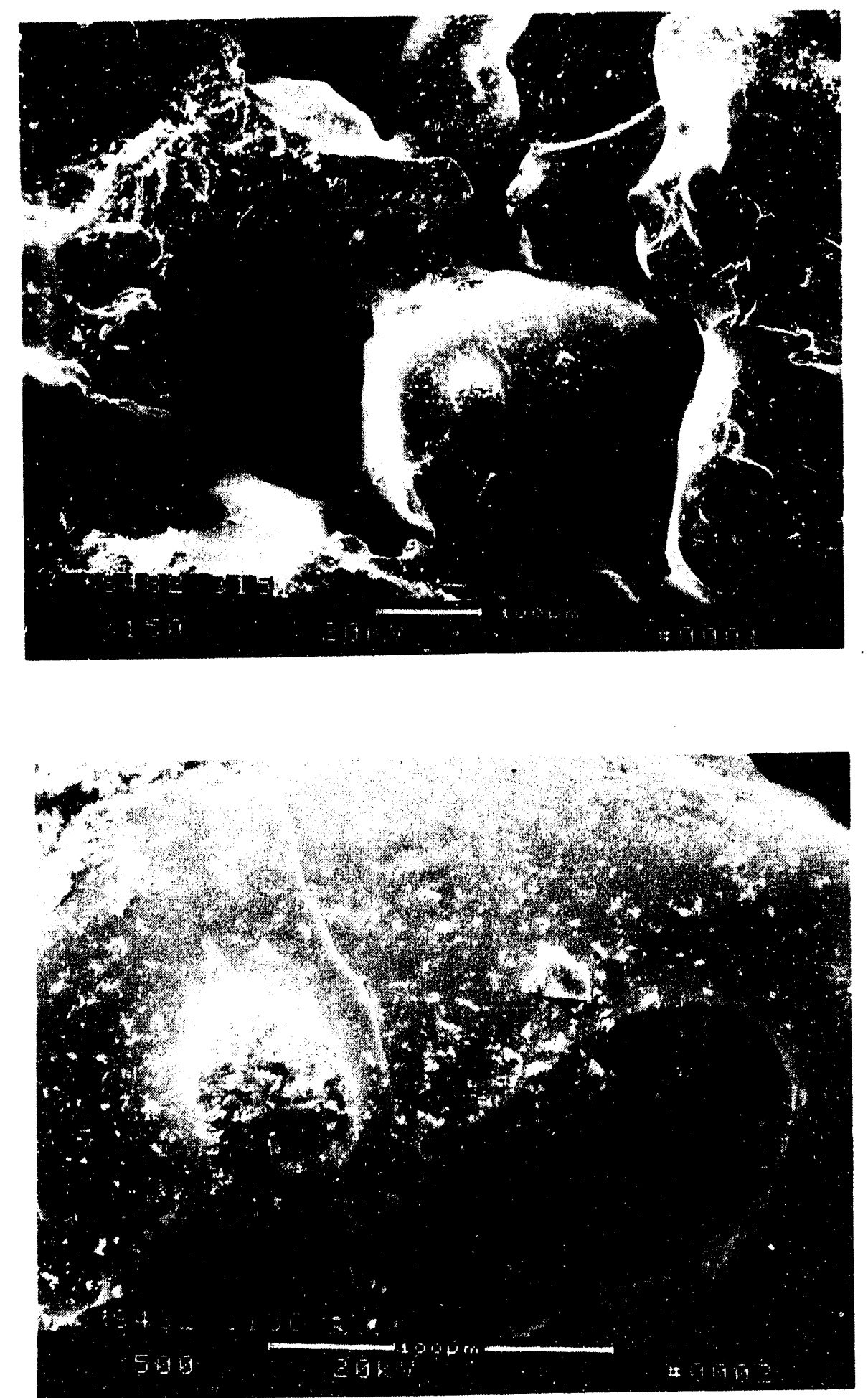

Figure 4a - Yorphology of The As-Manufactured Schunacher Dia Schumalith F40 Clay Bonded Silicon Carbide Pilter Matrix (S482/315C) 


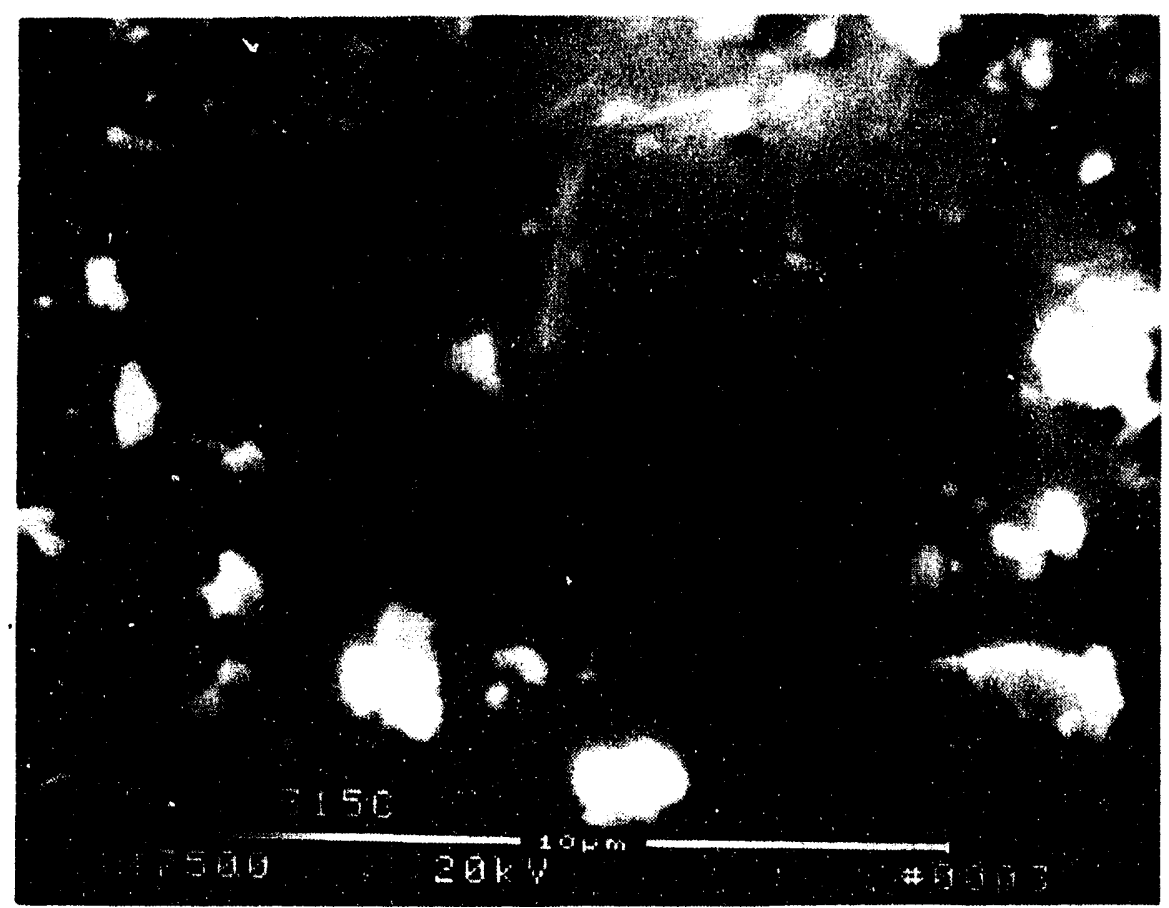

Figure 4b - Higher Magnification Micrograph of The Binder Phase Which Encapsulates The Silicon Carbide Grains In The Schumacher Dia Schunalith P40 Filter Matrix (S482/315C) 

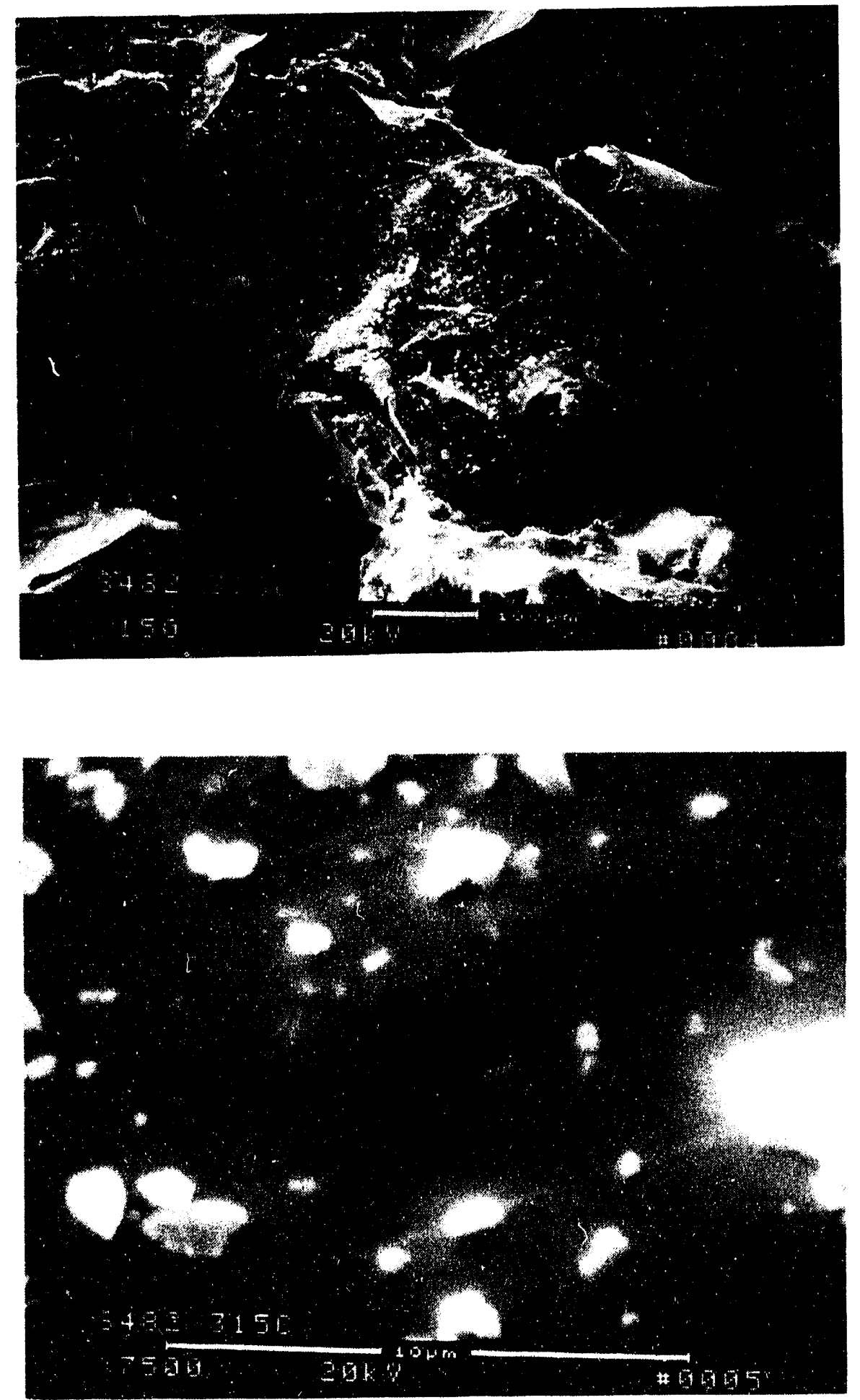

Figure 4c - Morphology of The Clay Bonded Silicon Carbide Grains At An Alternate Location Along The Schuancher Dia Schumalith F40 Pilter Matrix (S482/315C) 

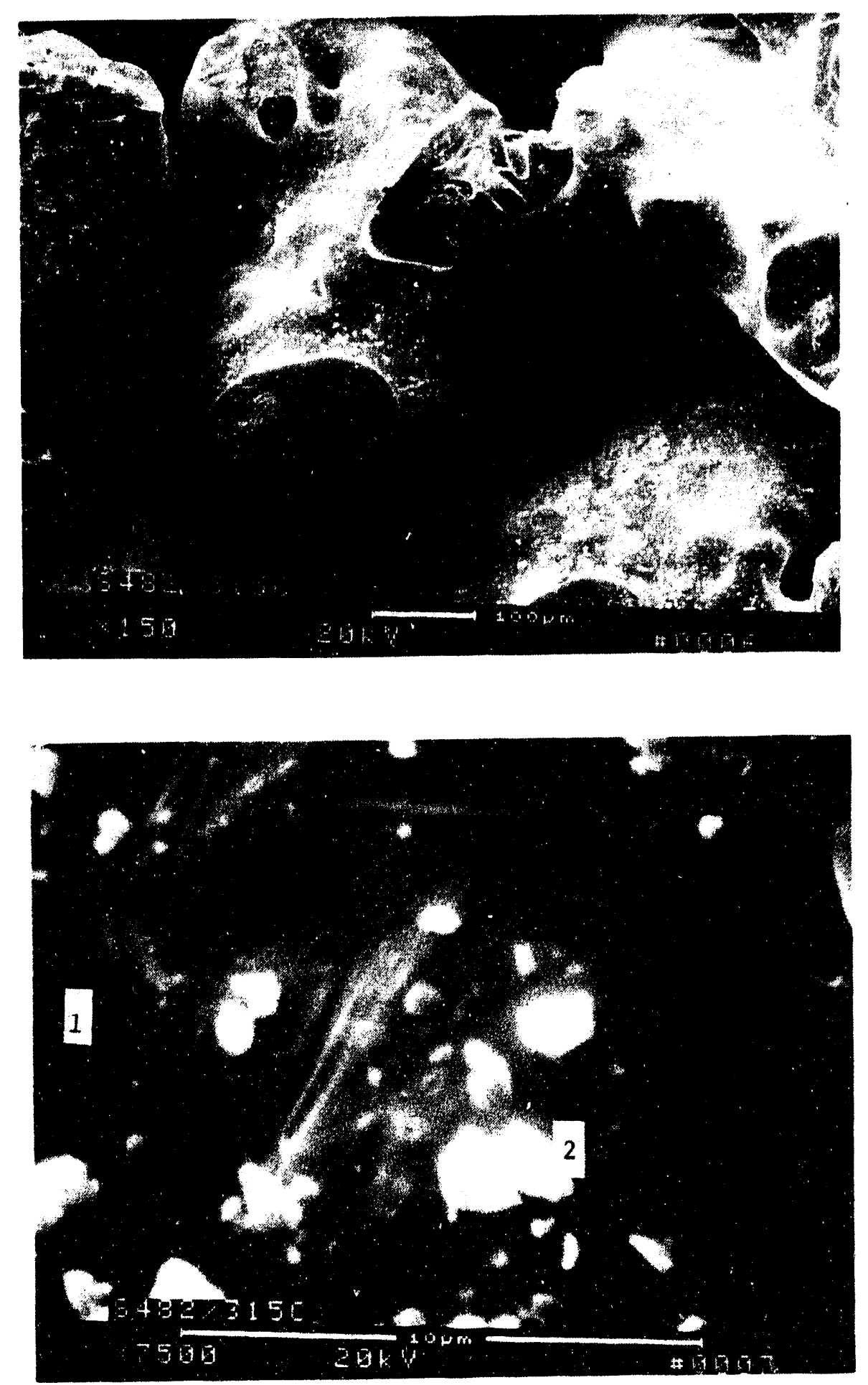

Figure 4d - Morphology of The Clay Bonded Silicon Carbide Grains At An Alternate Location Along The Schunacher Dia Schumalith F40 Filter Matrix (S482/315C) 
iron phases. Micron and submicron particulate-like fines are evident along the as-manufactured binder surface. Typically there are areas along the binder surface where crystalline rod-like features are evident. The composition of the crystalline features shown in Area 1 of Photo 7 in Figure 4 includes $49.81 \% \mathrm{O}, 38.81 \% \mathrm{Si}, 6.64 \% \mathrm{Al}, 1.98 \% \mathrm{~K}$, $1.40 \% \mathrm{Na}$, and $1.37 \% \mathrm{Fe}$ (atomic percent basis). The composition of the fines which appear to adhere to the binder surface (Area 2, Photo 7, Figure 4) includes $58.69 \% \mathrm{O}, 34.58 \% \mathrm{Si}, 3.75 \% \mathrm{Al}, 1.41 \% \mathrm{~K}, 1.32 \% \mathrm{Na}$, and $0.24 \% \mathrm{Fe}$.

In order to begin to explore the morphology of the Schumacher Dia Schumalith F40 filter matrix after 227 hours of exposure in the $900^{\circ} \mathrm{C}$ CFBC gas environment, a section of the matrix was removed from candle filter S2855/374C. The section was carbon coated so as not to mask the presence of sulfur within the matrix when EDAX analyses were conducted.

Figure 5 illustrates the morphology of the cross-sectioned CFBCexposed Schumacher Dia Schumalith candle filter matrix near the OD wall. Note the relatively open pore channel structure along the crosssectioned candle matrix, indicating that pore plugging via fines penetration had not occurred. The integrity of the fibrous aluminosilicate membrane along the $O D$ surface of the filter remained virtually intact, serving as the protective barrier which is supported by the underlying silicon carbide grains.

Photos 3 through 5 in Figures $5 b$ and $5 c$ illustrate the morphology of the fibrous OD membrane of the Schumacher Dia Schumalith F40 candle filter. Area scan analysis of the fibrous membrane area shown in Photo 5, Figure 5c indicates the presence of $63.64 \% 0,21.96 \%$ $\mathrm{Si}, 13.84 \% \mathrm{Al}$, and $0.57 \% \mathrm{~K}$. 

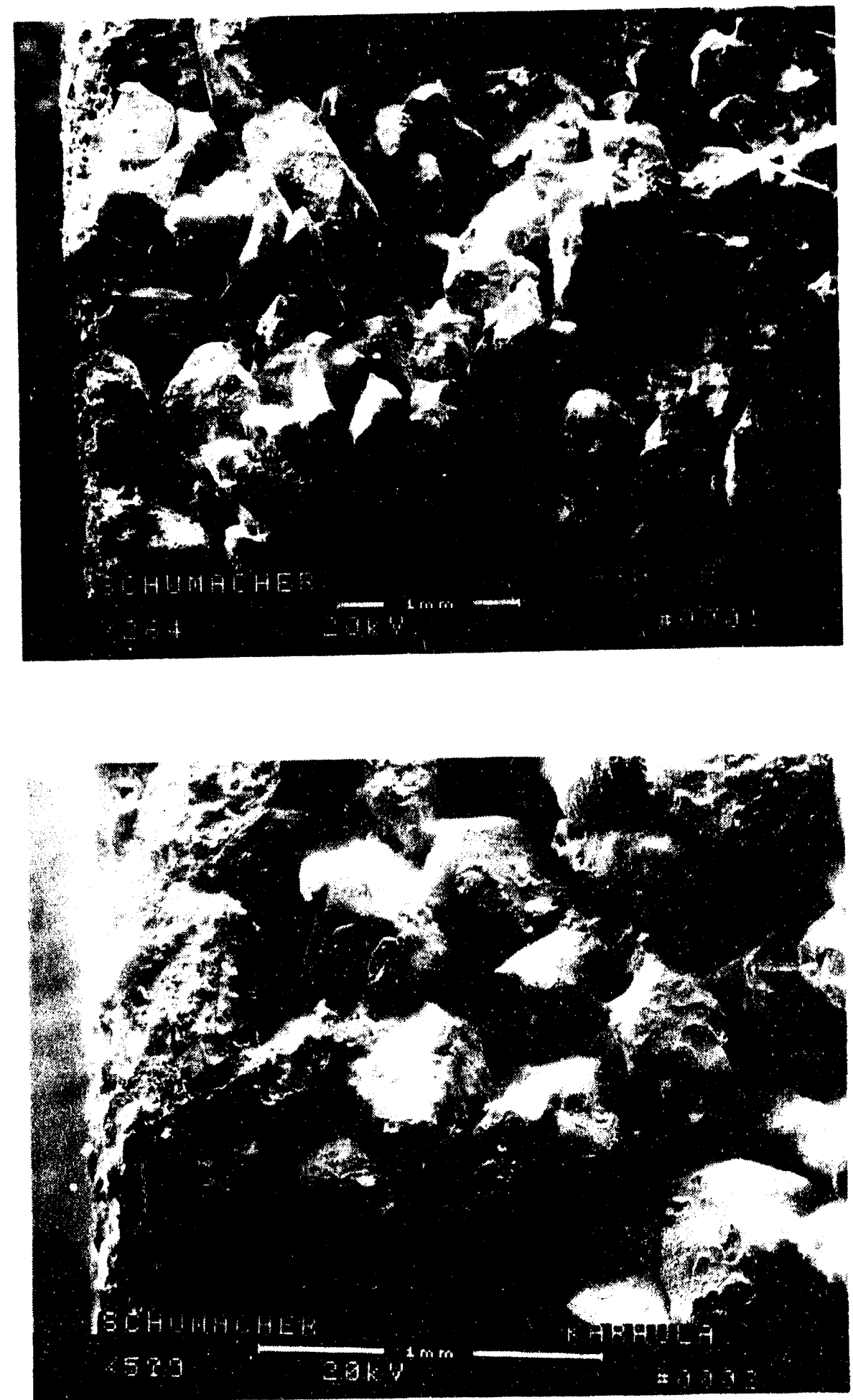

Figure 5a - Morphology of The Cross-Sectioned Schuacher Dia Schumilith F40 Matrix After 227 Hours of Exposure To The $900^{\circ} \mathrm{C}$ CFBC Gas Environment. Penetration of Fines Is Not Brident Along The OD Fibrous Membrane Or Pore Structure. 

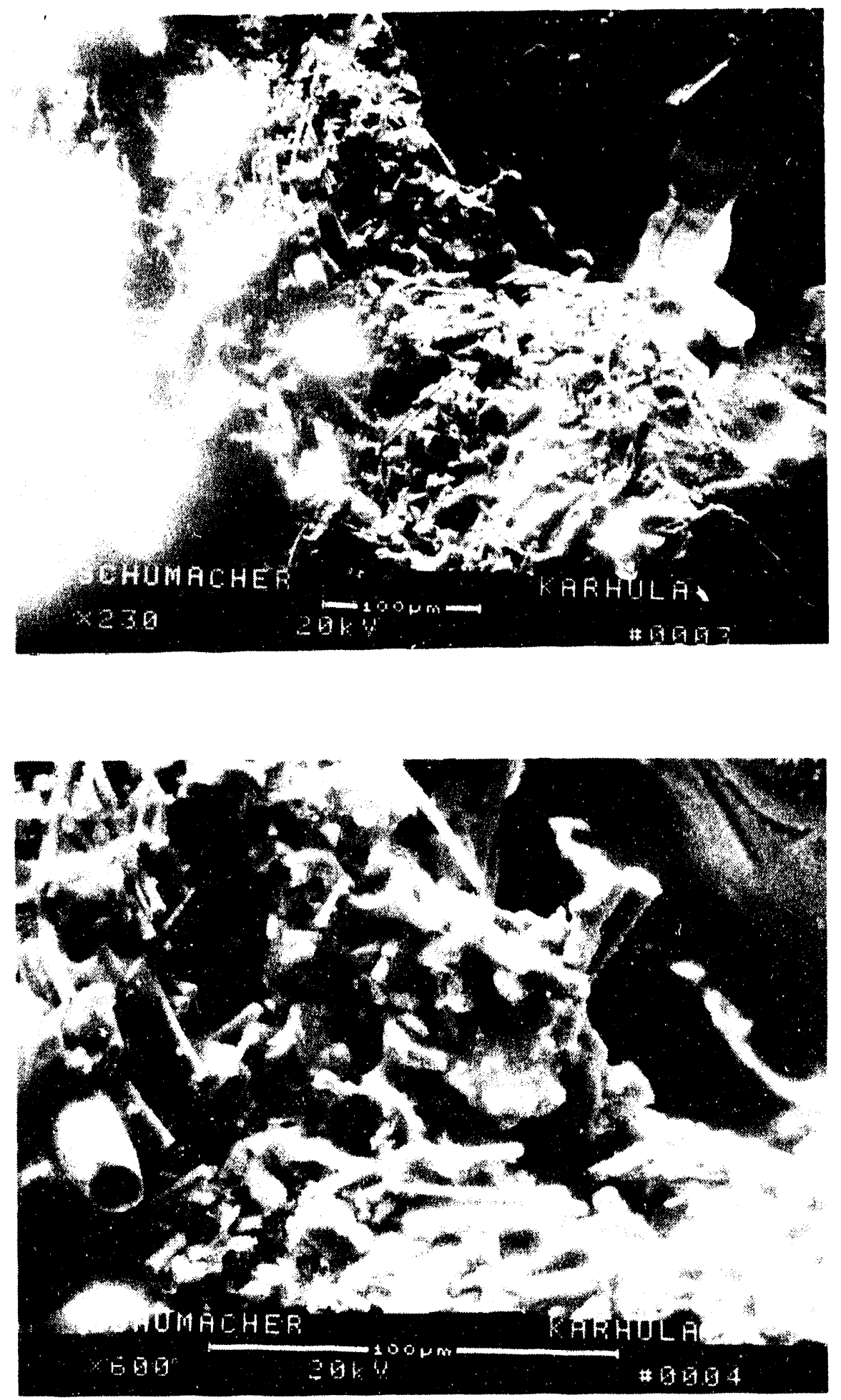

Figure 5b - Higher Magnification Nicrographs Illustrating The Morphology Of Fibrous OD Membrane of The Schumacher Dia Schumalith F40 Matrix After 227 Hours Of Exposure In The $900^{\circ} \mathrm{C}$ CFBC Gas Environment 


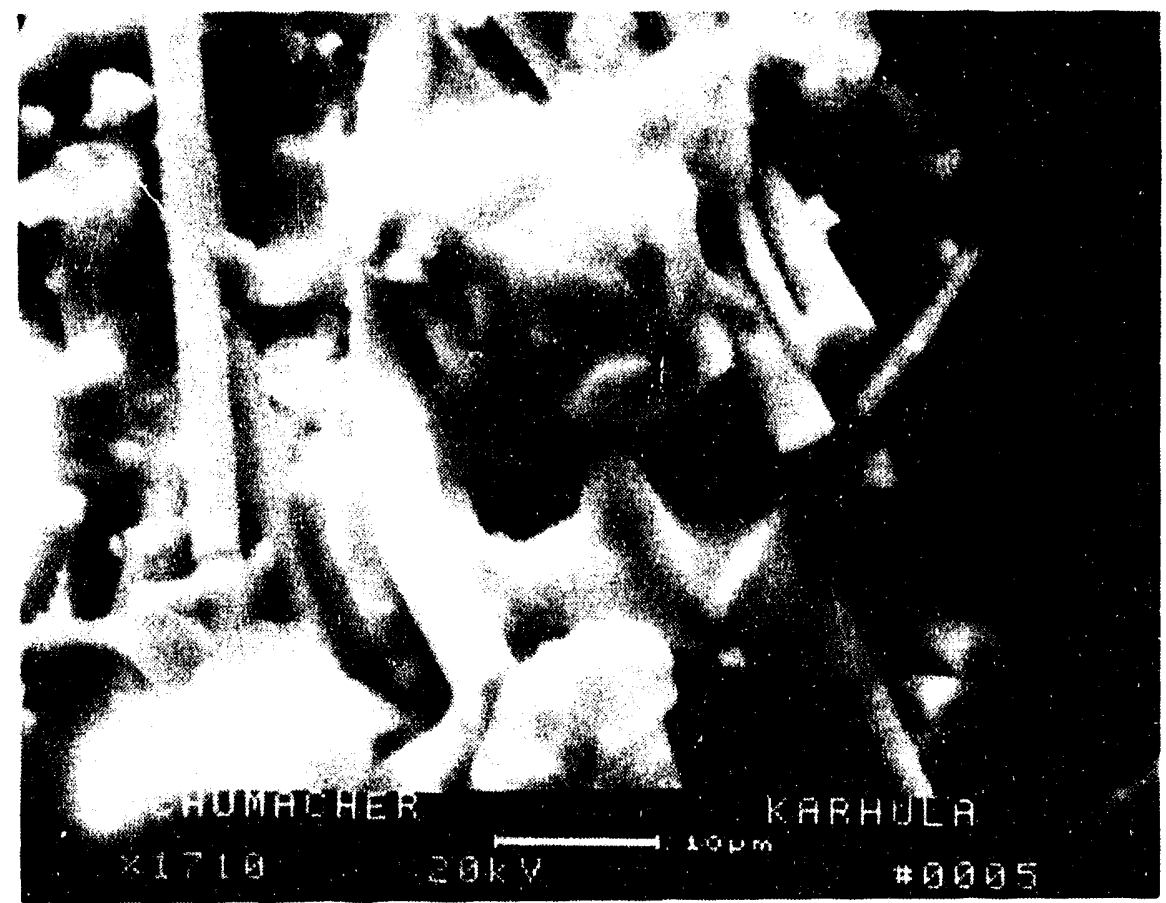

Figure 5c - Higher Magnification Micrograph Illustrating The Morphology Of The Fibrous OD Membrane of The Schumacher Dia Schumalith F40 Matrix After 227 Hours of Exposure In The $900^{\circ} \mathrm{C}$ CFBC Gas Environment 
Figure 6 shows the morphology of the clay bonded silicon carbide grains at approximately two grain layers below the OD fibrous membrane. The morphology of the binder phase (Area 1, Photo 6, Figure 6a) contains not only holes and ripples, but also what appears to be a phase change as indicated by the micron and submicron nodules that result along the smooth, as-manufactured binder surface (Photo 9, Figure 6b). The relatively large nodule in Area 1 contains $70.42 \% 0,20.85 \% \mathrm{Si}, 6.68 \%$ $\mathrm{Al}, 1.13 \% \mathrm{Na}$, and $0.90 \% \mathrm{Fe}$, while the submicron mat (Area 2) consists if $61.24 \% \mathrm{O}, 35.36 \% \mathrm{Si}, 1.81 \% \mathrm{Al}, 0.68 \% \mathrm{Na}, 0.42 \% \mathrm{Fe}, 0.26 \% \mathrm{~K}$, and $0.12 \%$ Ti.

Higher magnification of the binder phase which interconnects adjoining silicon carbide grains (Area 2, Photo 6, Figure 6a) is shown in Figure 7. Note the extensive coalescence of the nodules along the binder coated silicon carbide grain surface, as well as separation and/or depletion of the matrix surrounding the raised nodular formations. EDAX characterization of the raised nodules in Area 1 , Photo 14, Figure 7c indicate the presence of $77.65 \% \mathrm{O}, 17.19 \% \mathrm{Si}$, and 5.15\% Al which is comparable to the composition of the background binder phase (77.92\% $0,17.30 \% \mathrm{Si}$, and 4.78\% 11 ; Area 2, Photo 14, Figure 7c).

An extensive layer of fines is evident along the ID surface of the carbon coated cross-sectioned Schumacher Dia Schumalith F40 filter matrix. Extensive pore channel plugging via entrapped fines is not evident along the cross-sectioned filter ID surface shown in Photo 16, Figure 8a. The composition of the fines as determined by EDAX analysis consists of $65.62 \% 0,14.68 \% \mathrm{Si}, 12.28 \% \mathrm{Al}, 1.59 \% \mathrm{Ca}, 1.42 \% \mathrm{Na}, 1.25 \%$ $\mathrm{Fe}, 1.17 \% \mathrm{~K}, 0.70 \% \mathrm{Kg}, 0.53 \% \mathrm{Ti}, 0.46 \% \mathrm{Cl}$, and $0.30 \% \mathrm{P}$. The composition of the binder phase along the ID surface silicon carbide grains consists of $66.20 \% \mathrm{O}, 33.06 \% \mathrm{Si}, 0.47 \% \mathrm{Al}$, and $0.28 \% \mathrm{Na}$. Similarly the composition of the binder ligaments which joins adjacent grains along the ID surface consists of $67.04 \% 0,27.91 \% \mathrm{Si}, 3.16 \% \mathrm{Al}, 1.13 \% \mathrm{~K}$, and $0.77 \% \mathrm{Na}$. The binder phase which reanins along the cross-sectioned 

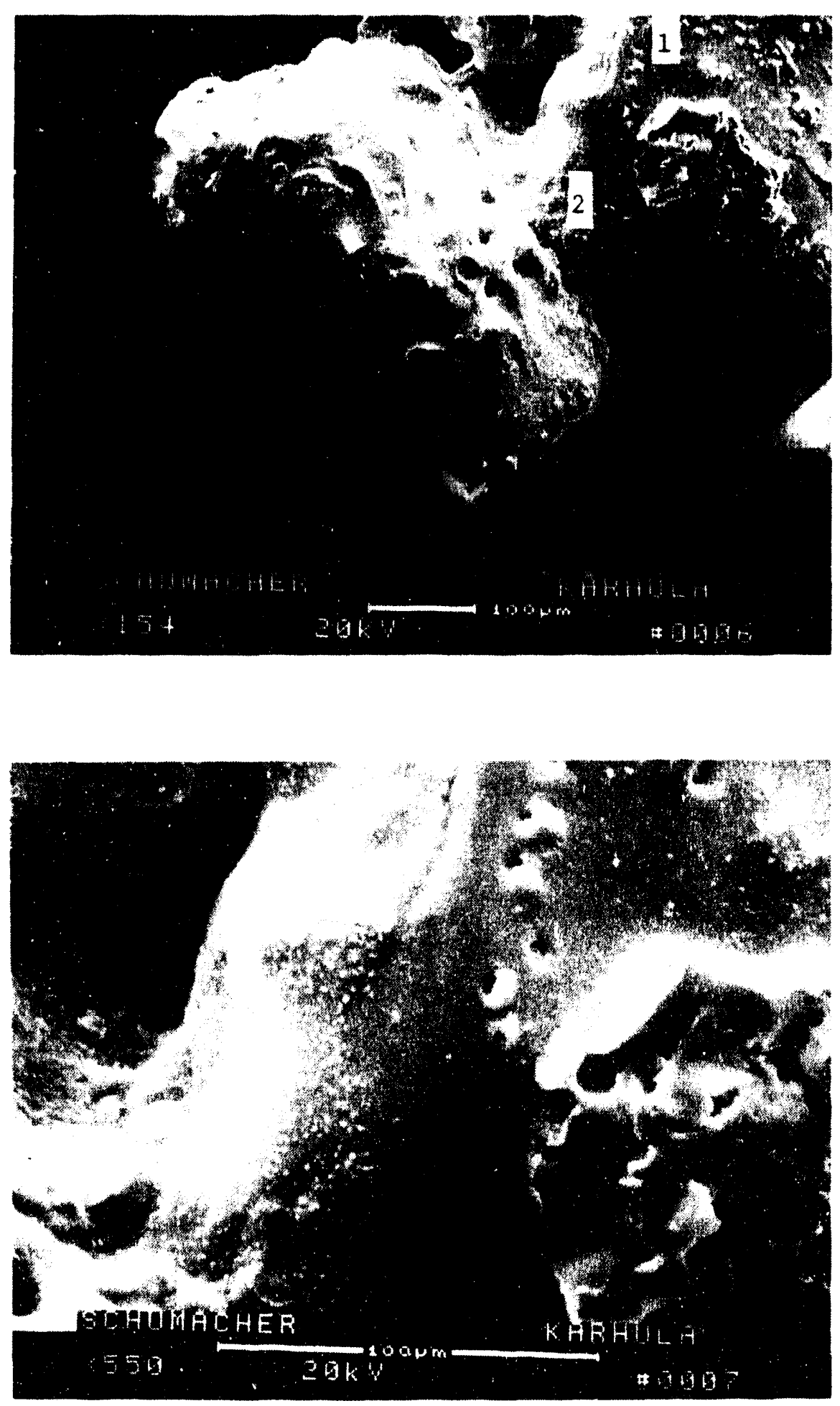

Figure 6a - Morphology Of The Binder Coating Along The Silicon Carbide Grains At Approximately Two Grain Layers Below The Fibrous OD Membrane 

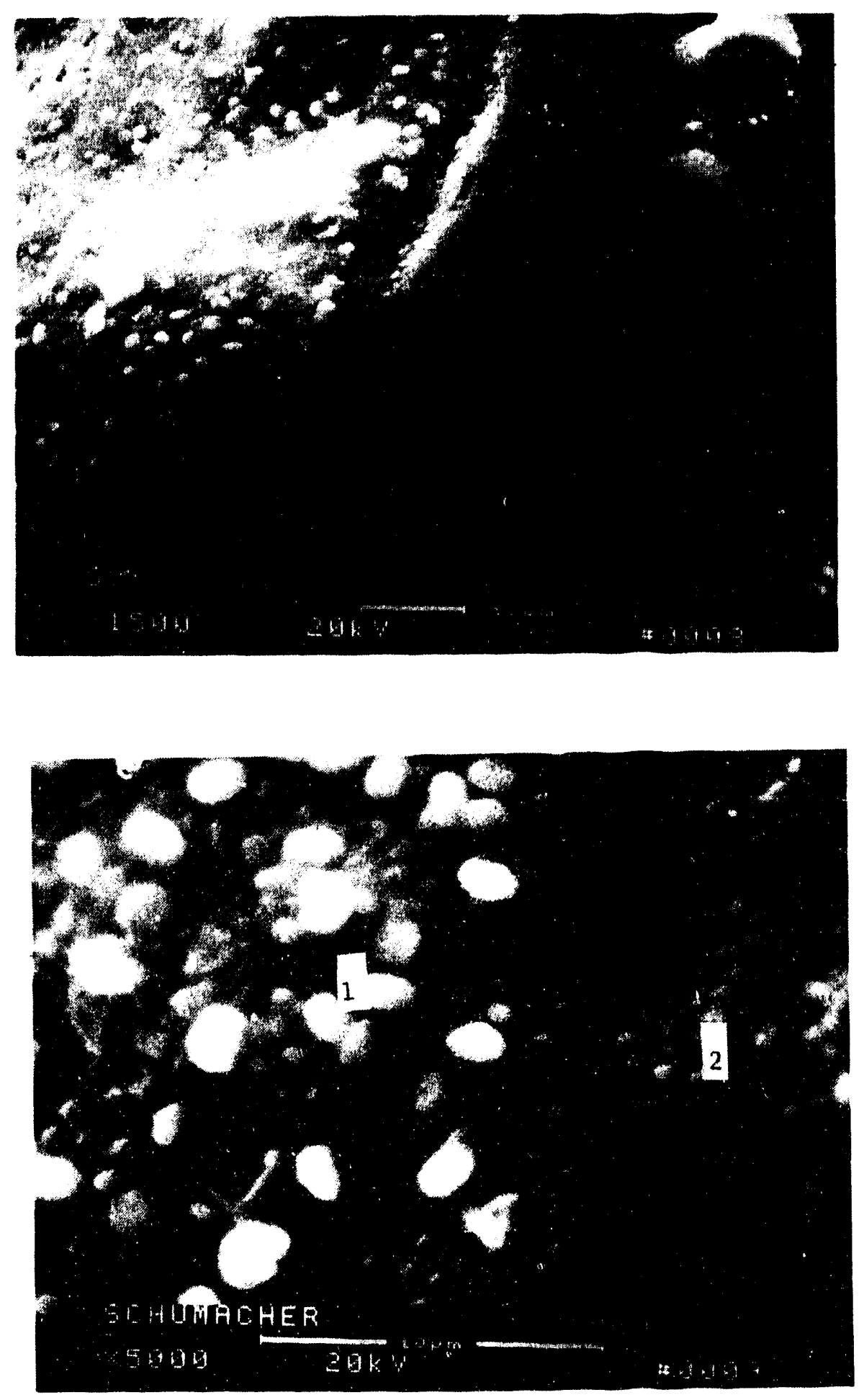

\section{Figure 6b - Higher Magnification Micrographs Indicating The Phase Transformations That Result Along The Binder Coating of The Schumacher Dia Schumalith P40 Silicon Carbide Grains After 227 Hours of Exposure In The Crec Gas Barironment}



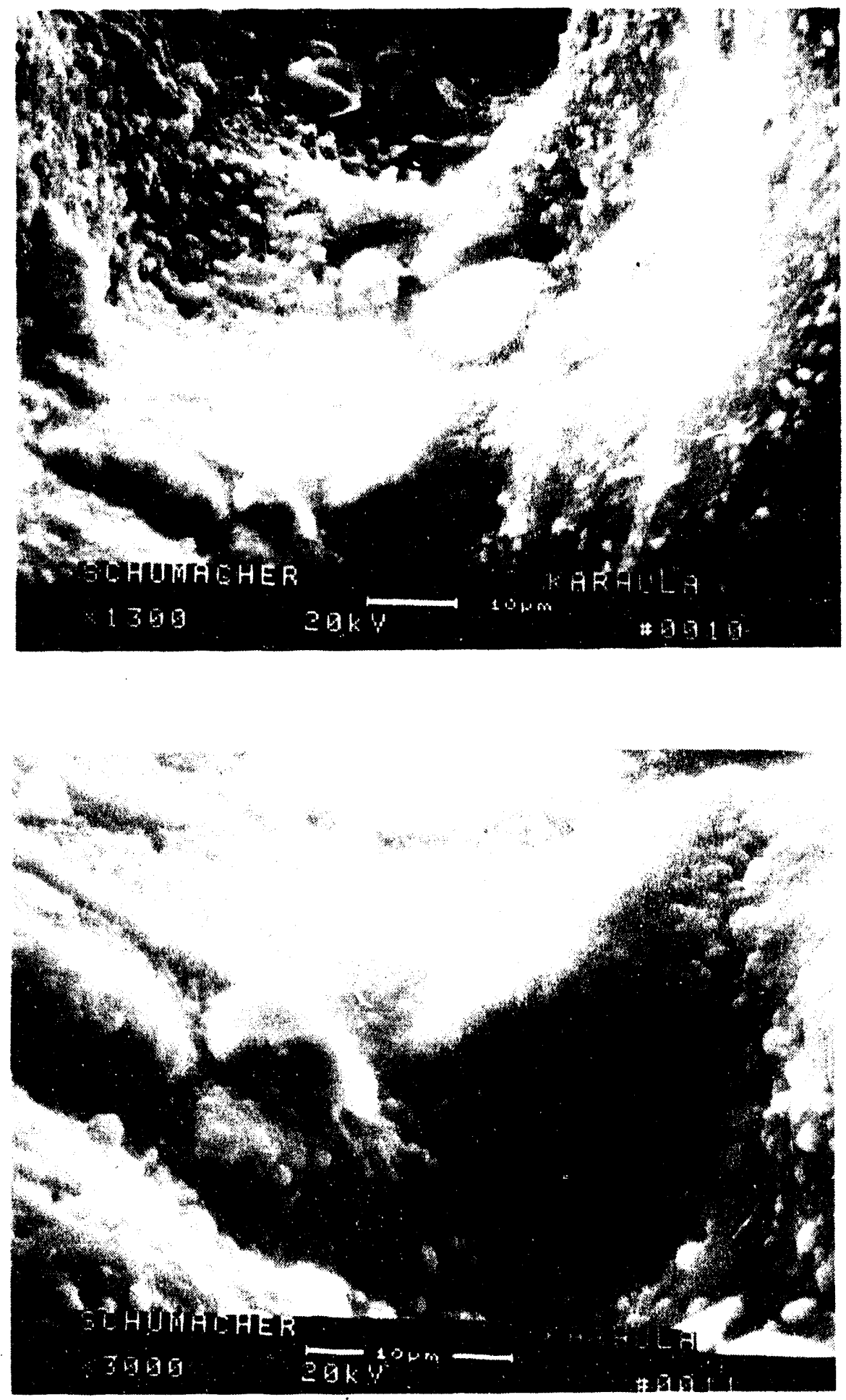

Figure 7a - High Magnification Micrographs Illustrating The Phase Transformations That Besult Along The Surface Of The Binder Ligaments That Hold Adjoining Silicon Carbide Grains

Together In The CFBC-Exposed Schumacher Dia Schumalith F40 Matrix 

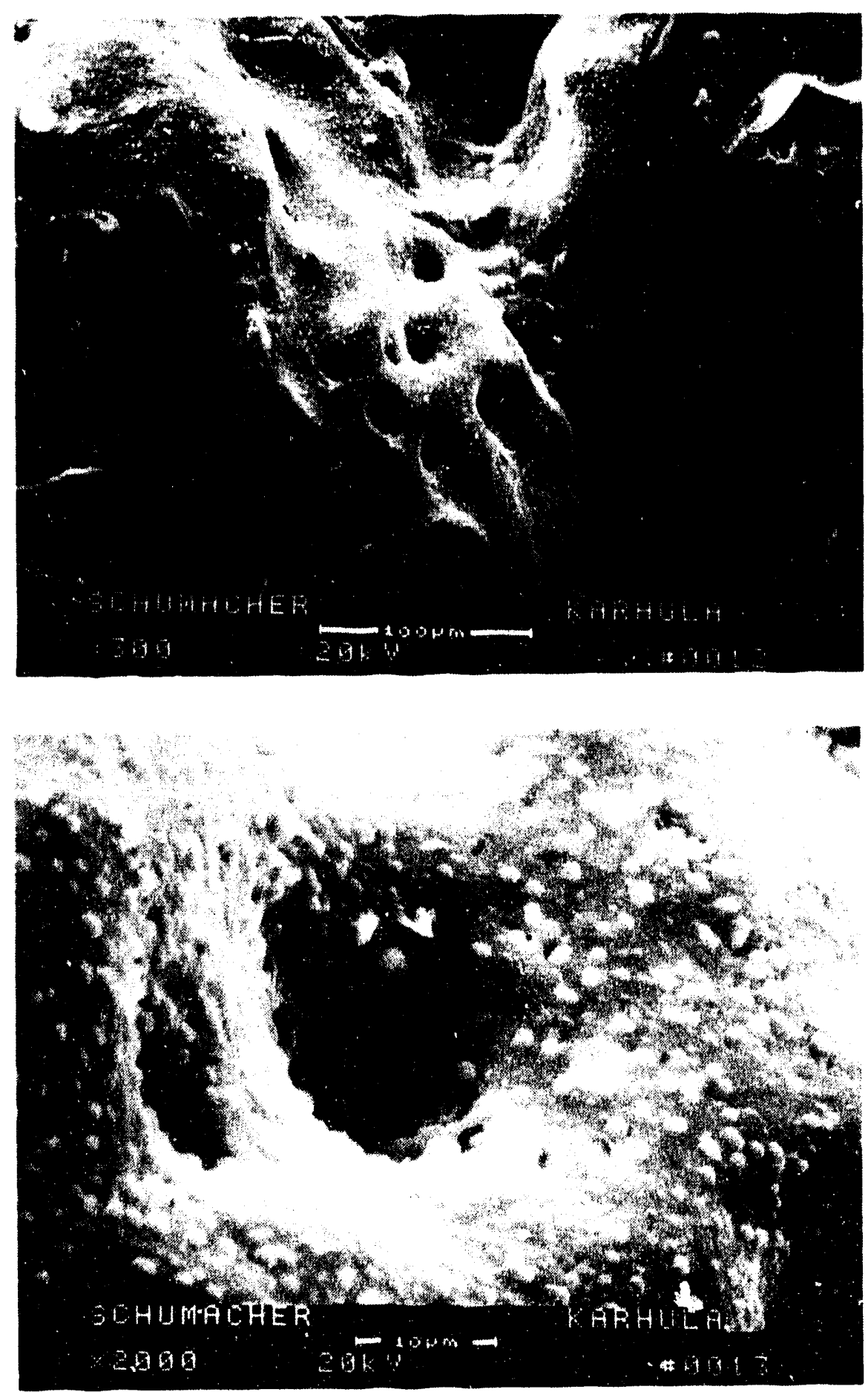

Figure 7b - High Magnification Micrographs Illustrating The Phase Changes That Result Along The Binder Ligament Surfaces In The CFBC-Exposed Schunacher Dia Schunalith F40 Vatrix 


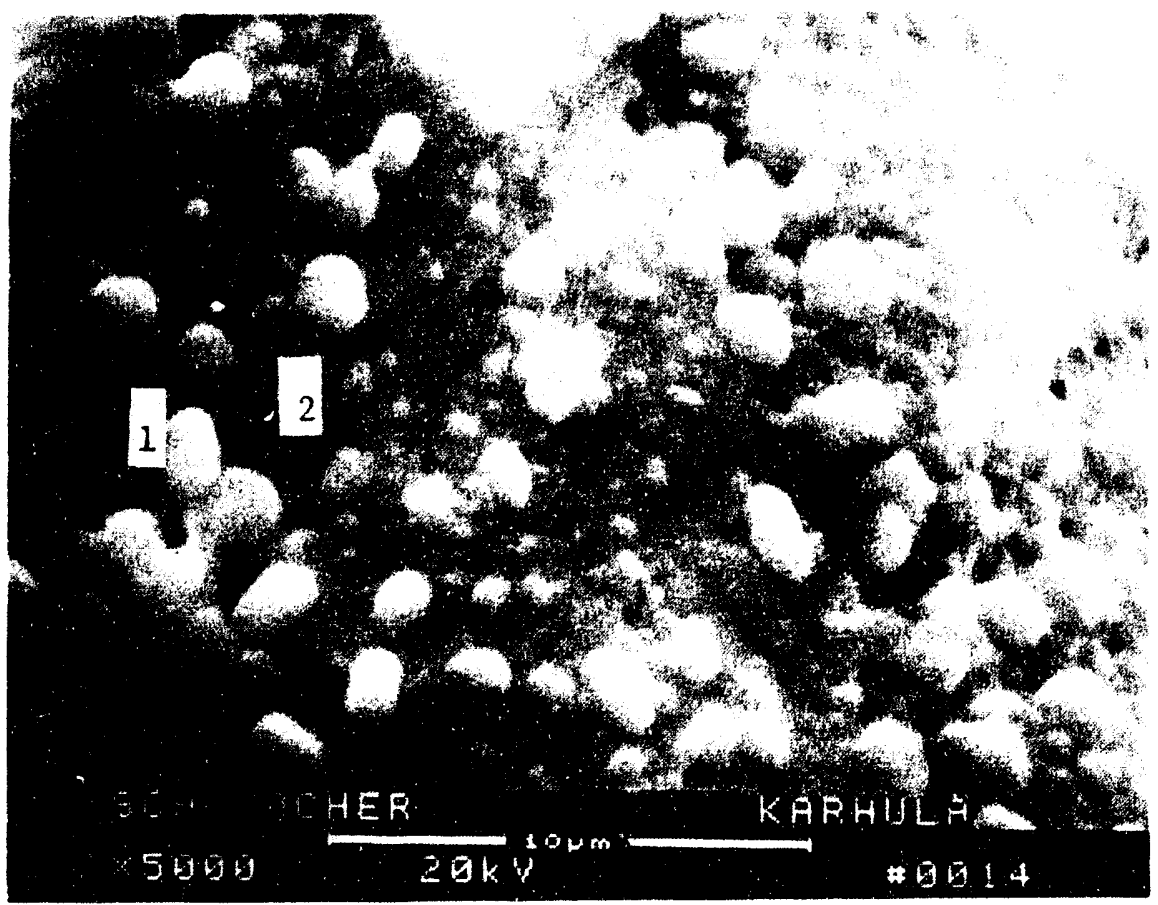

Figure 7c - High Vagnification Vicrograph Illustrating The Coalescence And Phase Transformations Which Occurred Along The Schumacher Dia Schumalith F40 Yatrix After 227 Hours Of Exposure In The CFBC Gas Environnent 

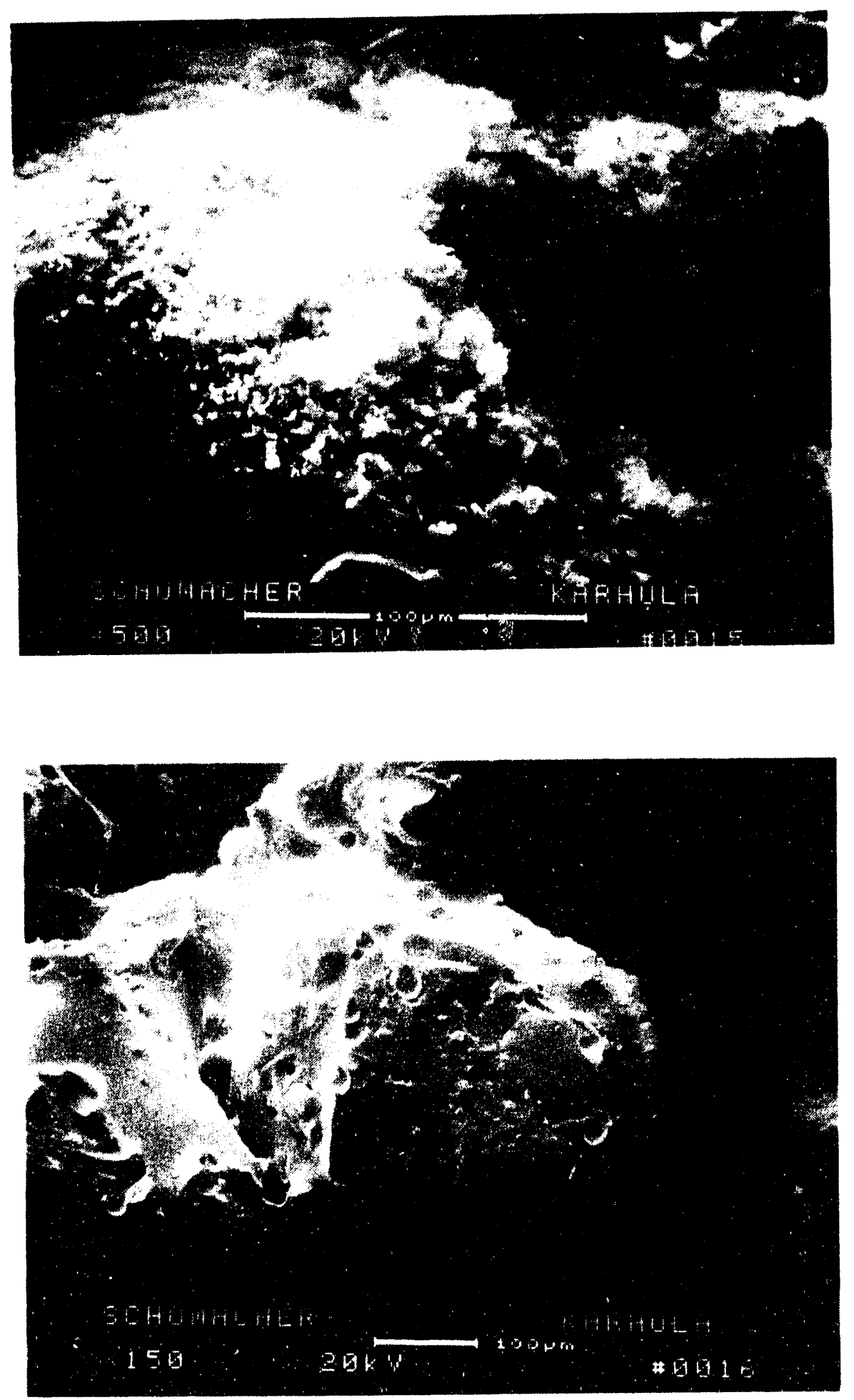

Figure 8a - Yorphology Of The Ash Fines Along The ID Surface Of The Schumacher Dia Schumalith P40 Matrix 


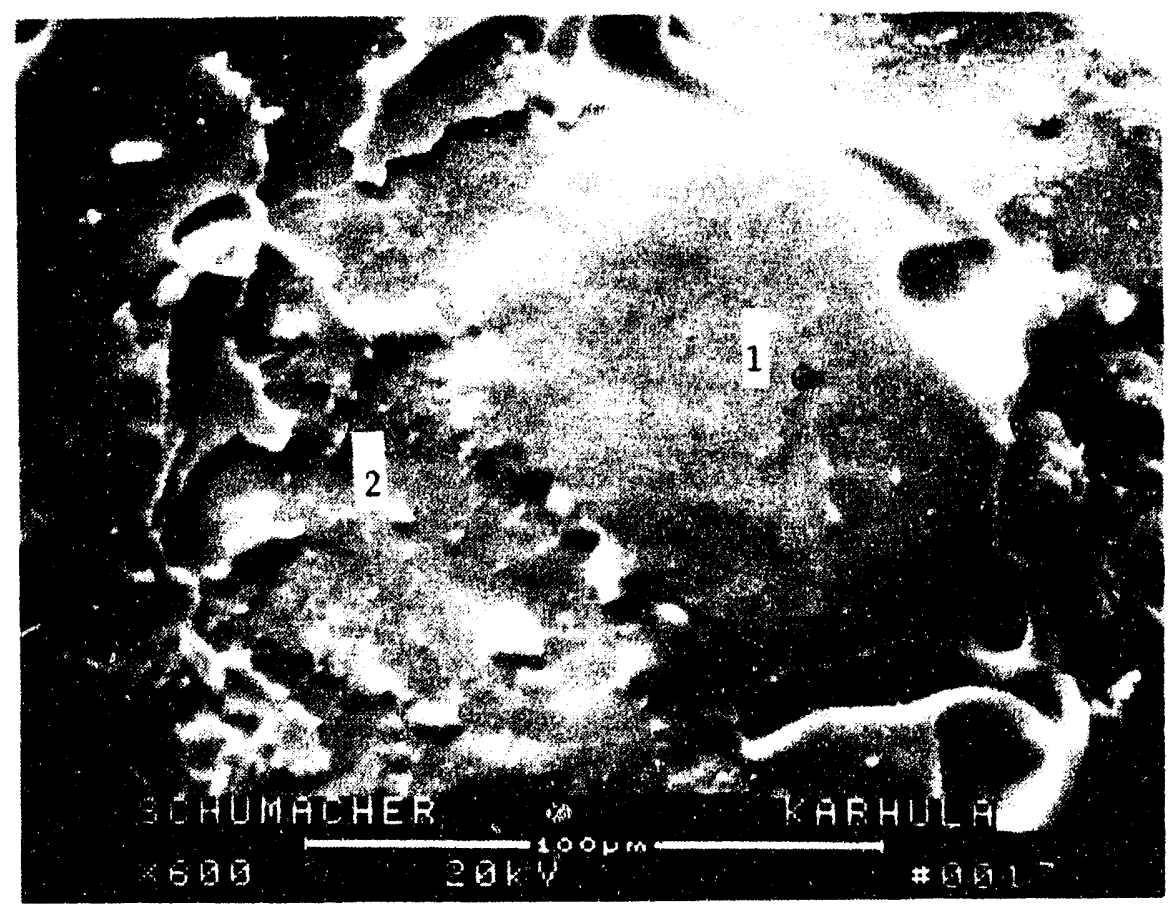

Figure 8b - Higher Magnification Micrograph of The Binder Coating Along The Silicon Carbide Grains Near The Cross-Sectioned Filter ID Surface 
grain in Area 1 , Photo 17 , Figure $8 \mathrm{~b}$ is once again a silica-enriched aluminosilicate phase $(62.32 \% 0,29.06 \% \mathrm{Si}, 6.05 \% \mathrm{\Lambda l}, 1.65 \% \mathrm{~K}$, and $0.93 \%$ $\mathrm{Na}$, while the underlying silicon carbide grain contains a thin oxide coating ( $88.26 \% \mathrm{Si}, 11.74 \% \mathrm{0})$. The concentration of carbon is not semiquantitatively determined by EDAX analysis.

Note that sulfur was not detected along either the binder surface of the CFBC-exposed silicon carbide grains or in the fines that had collected along the filter ID surface.

A second series of SEN/EDAX analyses were performed along the cross-sectioned Schumacher Dia Schumalith F40 matrix in an attempt to demonstrate the homogeneity of the filter matrix after 227 hours of exposure in the CFBC gas environment. As shown in Figure 9, the silicon carbide structure is relatively open, lacking entrapped fines within its pore channels. Frequently several micron-sized holes are evident within the Schumacher Dia Schumalith F40 binder phase (Photos 4 and 5, Figure $9 b$ and $9 c)$. Similar hole formations are evident along the binder coating of the silicon carbide grains shown in Figure 10, as well as the mat-like nodular formations which were previously described.

As shown in Photo 11, Figure 11a, a section of the binder coating which is adjacent to a hole in the binder phase appears to be raised or blistered. EDAX analysis of Area 1, Photo 11, Figure 11a indicates the presence of silicon, oxygen, aluminum, potassium, and sodium. Higher magnification micrographs of the mottled binder surface is shown in Photo 12, Pigure 11b. EDAX analysis of the raised 1-2 $\mu \mathrm{m}$ formation in Area 1, Photo 12, Figure 11b indicates the presence of $52.37 \% \mathrm{O}, 42.39 \% \mathrm{Si}, 3.91 \% \mathrm{Al}, 0.94 \% \mathrm{~K}$, and $0.39 \% \mathrm{Na}$. The underlying binder phase which appears to contain rod-like formations consists of $49.05 \% \mathrm{Si}, 39.55 \% 0,8.60 \% \Lambda 1,2.10 \% \mathrm{~K}$, and $0.70 \% \mathrm{Na}$. 

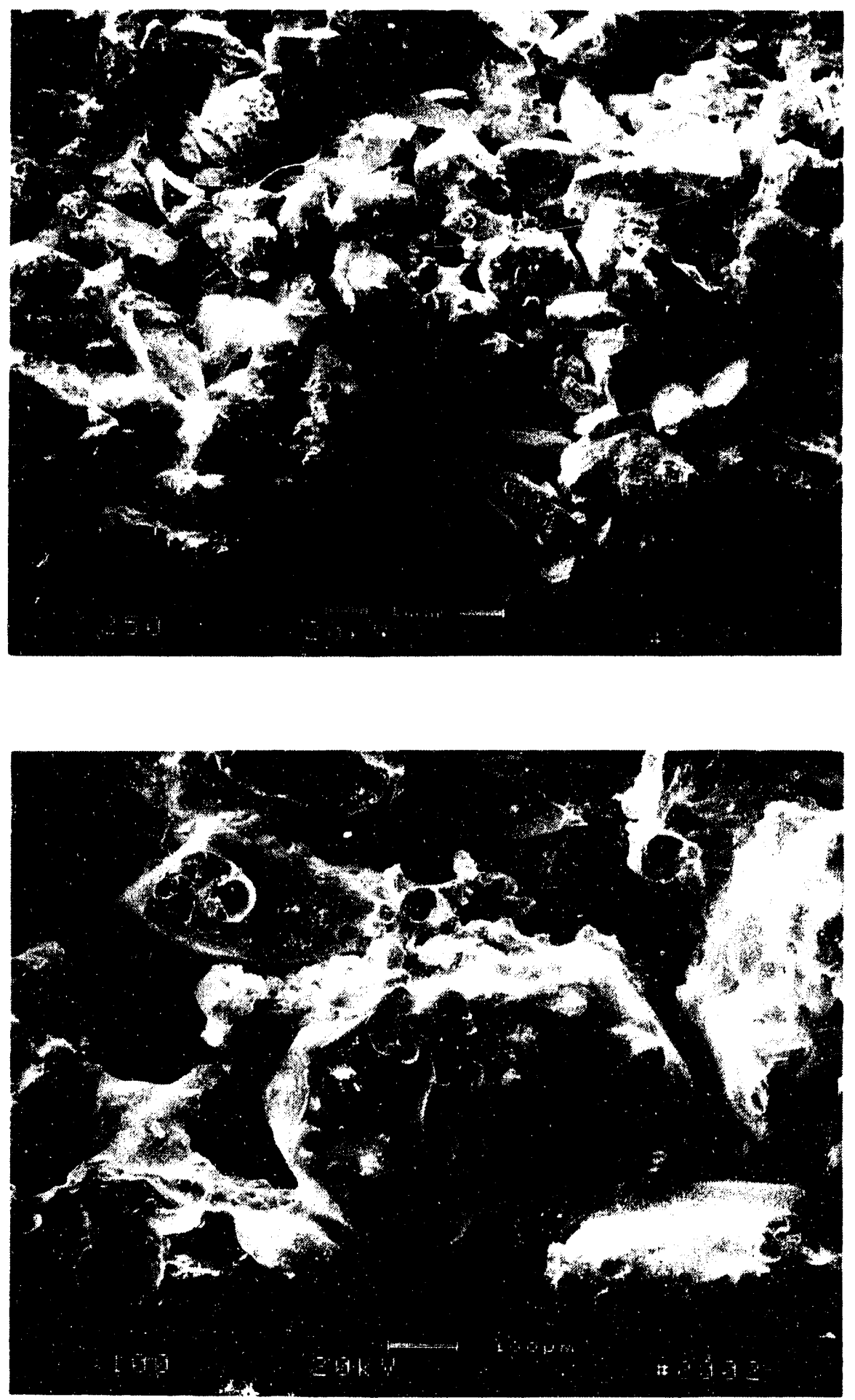

Figure 8a - Yorphology of The Binder Coated Silicon Carbide Grains In The Schumacher Dia Schumalith F40 Filter Matrix After 227 Hours of Exposure In The CFBC Gas Environnent 

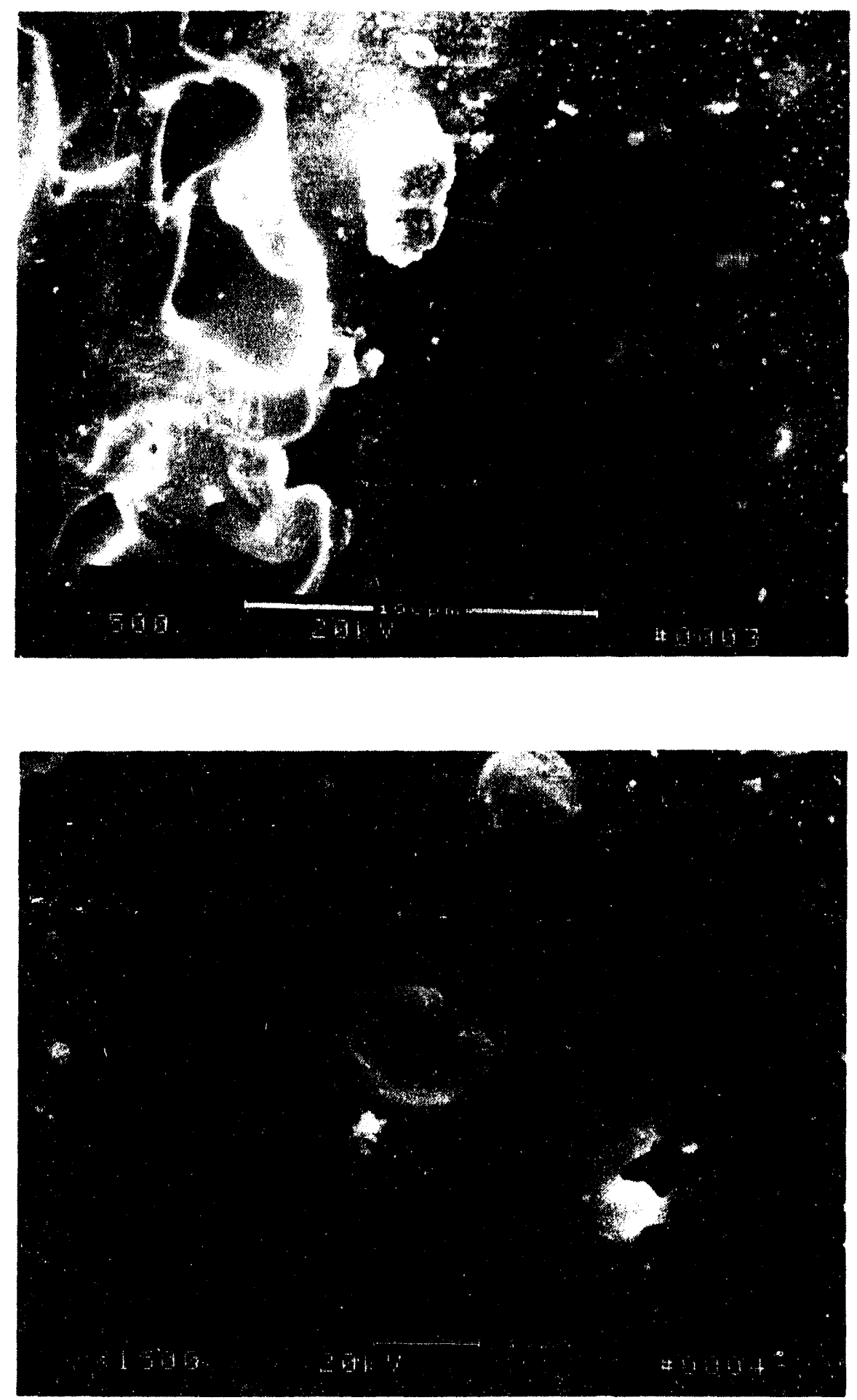

Figure 9b - Higher Magnification Micrographs Detailing The Micron-Sized Bole Pormations In The Binder Costing of The CFBC-Exposed Schumacher Dia Schumalith F40 Pilter Matrix 


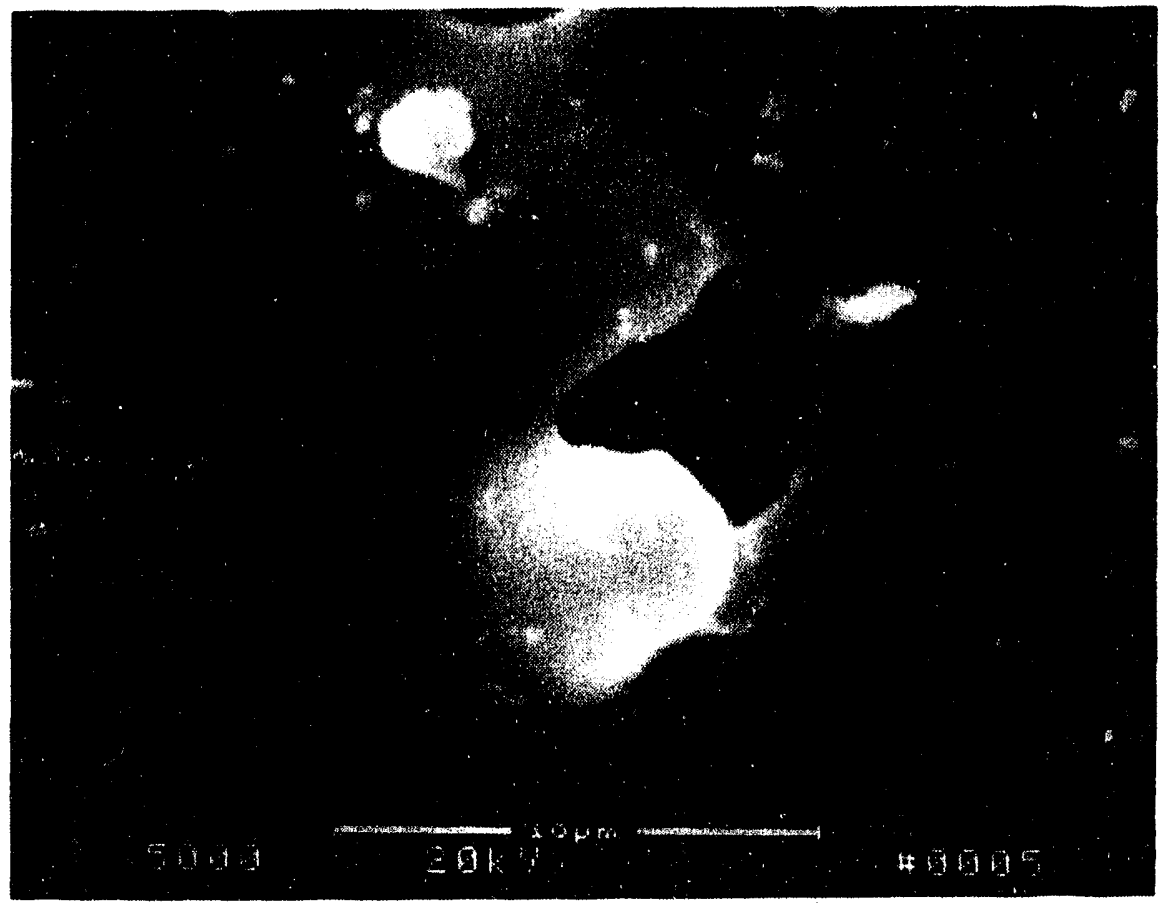

Figure 8c - Higher Magnification Micrograph Illustrating The Hole Formations In The Binder Phase of The Schumacher Dia Schumalith F40 CFBC-Exposed Silicon Carbide Grains 

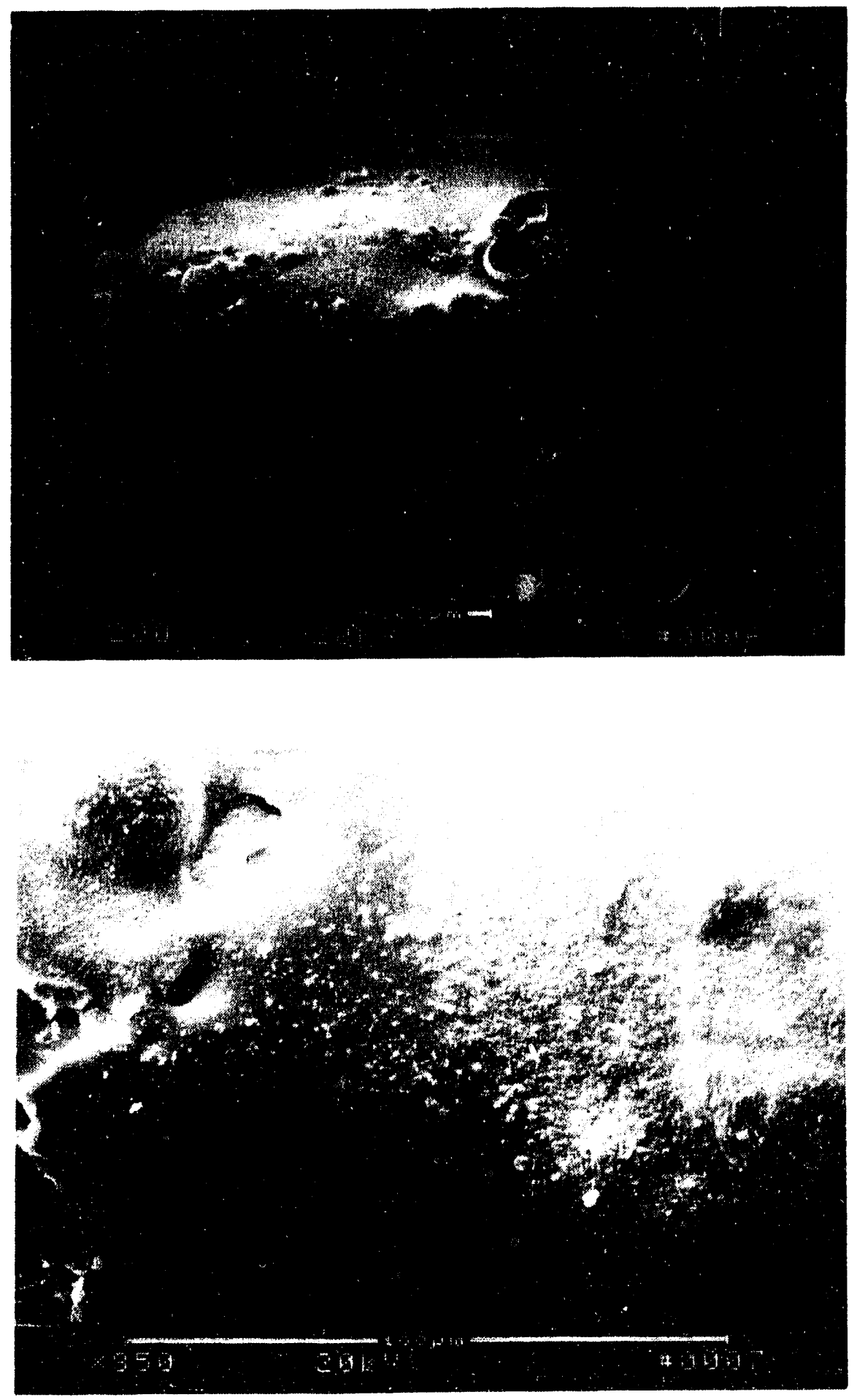

Figure 10a - Korphology of The Clay Bonded Silicon Carbide Grains At An Alternate Location Within The CFBC-Exposed Schumacher Dia Schumalith P40 Matrix 

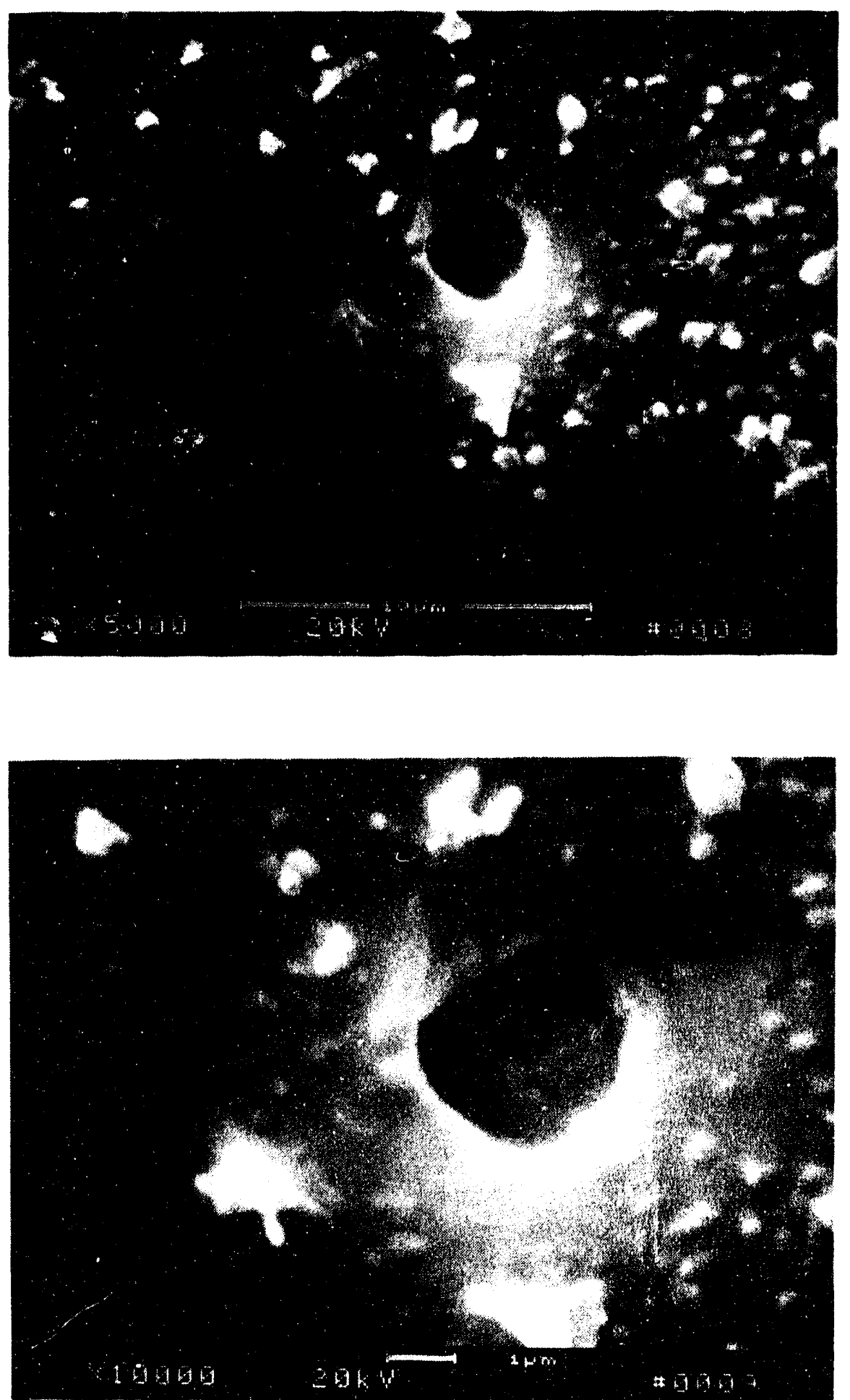

Figure 10b - Nicrographs Illustrating The Yottled Surface And Hole Formations Along The Binder Coating of The CPBC-Exposed Schumacher Dia Schumalith F40 Filter Matrix 

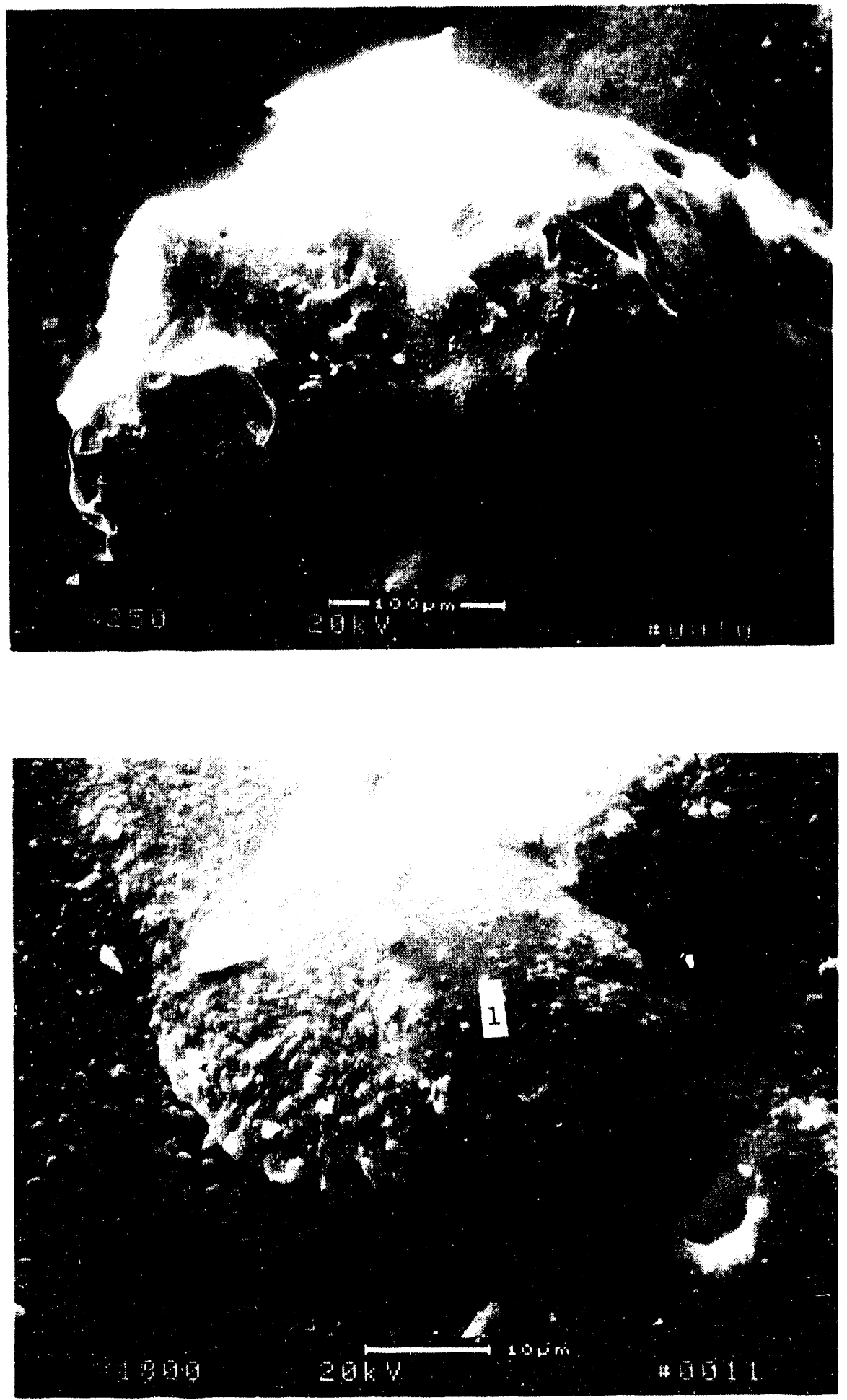

Figure 11a - Yottled And Blister-Like Appearance Of The Binder Coating Of The Clay Bonded Silicon Carbide Schumacher F40 Matrix After 227 Hours of Exposure In The $900^{\circ} \mathrm{C}$ CFBC Gas Environment 


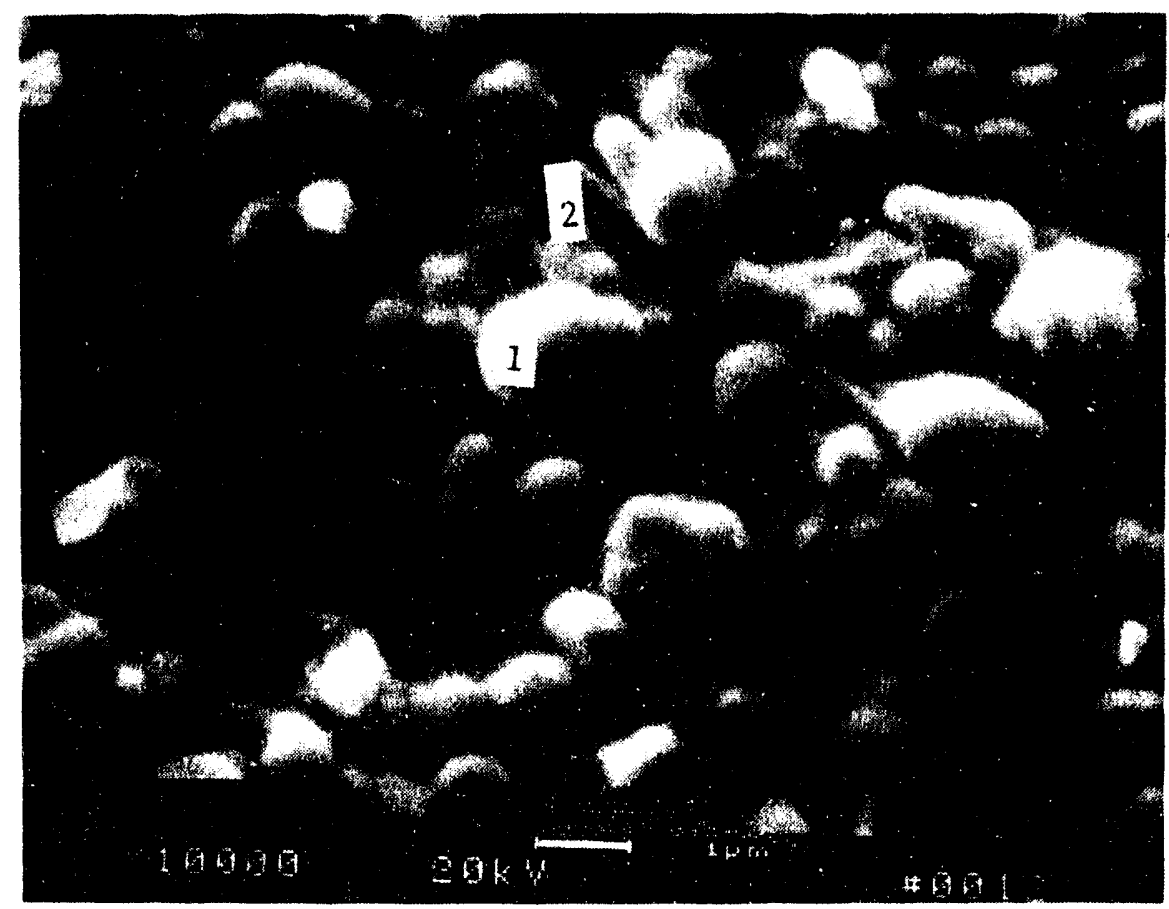

Figure 11b - Bigh Magnification Micrograph Illustrating The Nodular Forantions That Result Fron Phase Changes Within The Silica-Bnriched Binder Coating Along The Silicon Carbide Grains In The CFBC-Exposed Schumacher Dia Schumalith F40 Filter Matrix 
Figure 12 shows the morphology of the binder ligament surface and interface between two adjoining silicon carbide grains. Figure 13 illustrates the rather mottled surface blister-like appearance of the binder phase which coats the silicon carbide grains in the CFBC-exposed Schumacher Dia Schumalith F40 filter matrix.

In order to provide higher resolution of the surface morphology changes that have occurred within the CFBC-exposed filters, an alternate section of the Schumacher Dia Schumalith matrix was removed and coated with gold prior to further SEM/EDAX characterization. Figure 14 shows the morphology of the gold coated fibrous OD membrane and underlying silicon carbide support grains in the CFBC-exposed Schumacher Dia Schumalith F40 matrix. Note the relatively open pore channels in the microstructure, indicating that fines have not penetrated through the outer membrane surface.

Photo 3 in Figure $14 \mathrm{~b}$ shows the adherence of the fibrous outer membrane to the first silicon carbide grain in the underlying support structure. Fines appear to be attached to the fibers present in the OD membrane (Photo 5, Figure 14c). EDAX analysis of the fines shown in Area 1 (Photo 5, Figure 14c) indicate the presence of $61.92 \% 0,19.80 \%$ $\mathrm{Al}, 15.01 \% \mathrm{Si}, 1.42 \% \mathrm{Ca}, 1.10 \% \mathrm{Na}$, and $0.76 \% \mathrm{Fe}$. Round, nodular areas are also evident along the surface of the aluminosilicate fibers. EDAX analysis of these features (Area 2, Photo 5, Figure 14c) indicates the presence of $57.96 \% 0,27.65 \% \mathrm{Al}, 13.89 \% \mathrm{Si}$, and $0.51 \% \mathrm{Fe}$.

Figure 15 illustrates the morphology of the binder ligament between two adjacent silicon carbide grains that are directly below the fibrous OD membrane of the CFBC-exposed Schumacher Dia Schumalith F40 filter matrix. Higher magnification of Area 1, Photo 6, Figure 15a is shown in Photo 7, Figure 15a. Note the appearance of mat-like, nodular strands which formed along the binder phase of the clay bonded silicon carbide Schumacher Dia Schumalith F40 filter matrix. EDAX analysis of 

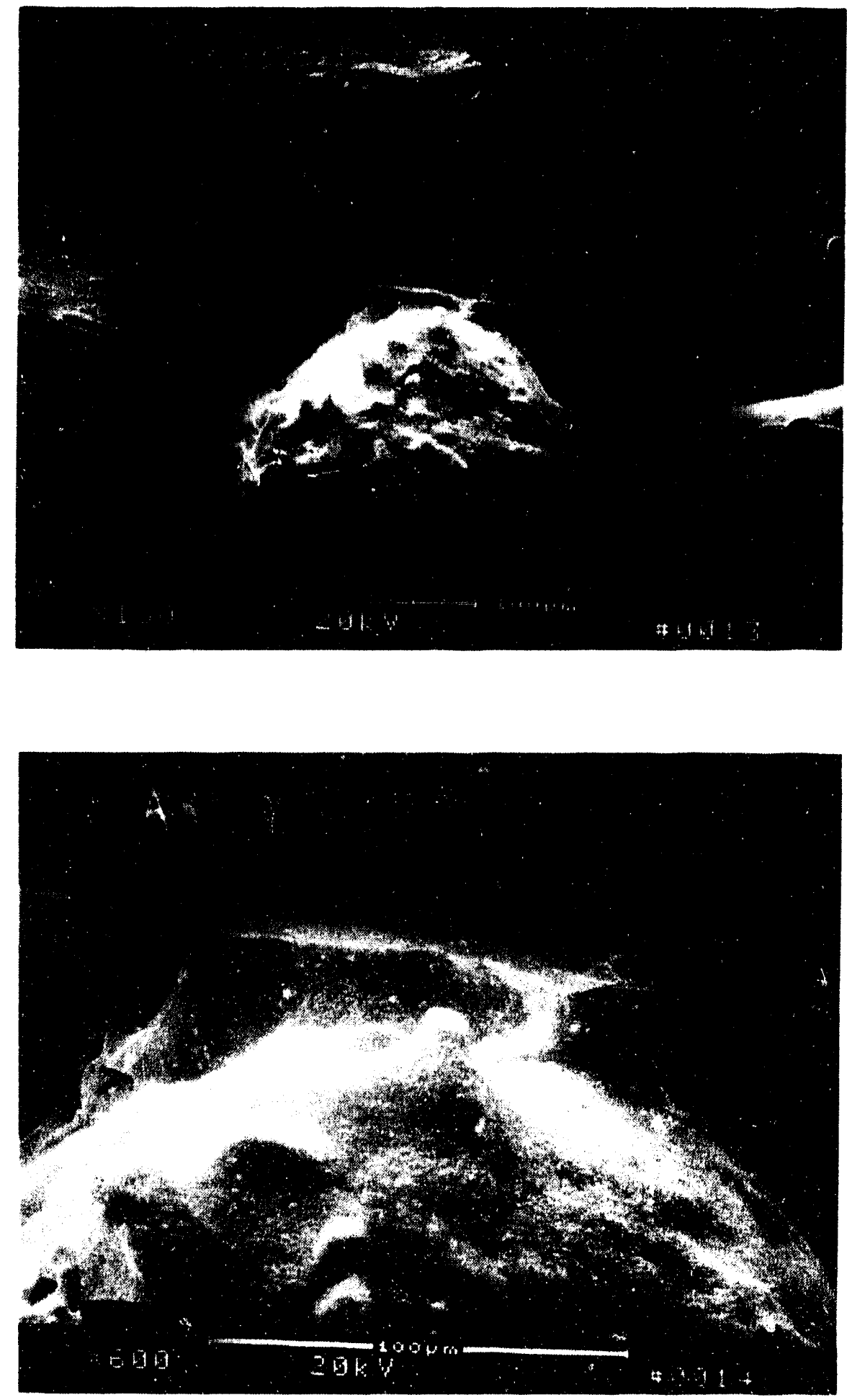

Figure 12a - Morphology of The Ligament And Interconnect Binder Phase In The CFBC-Exposed Schumacher Dia Schumalith F40 Matrix 

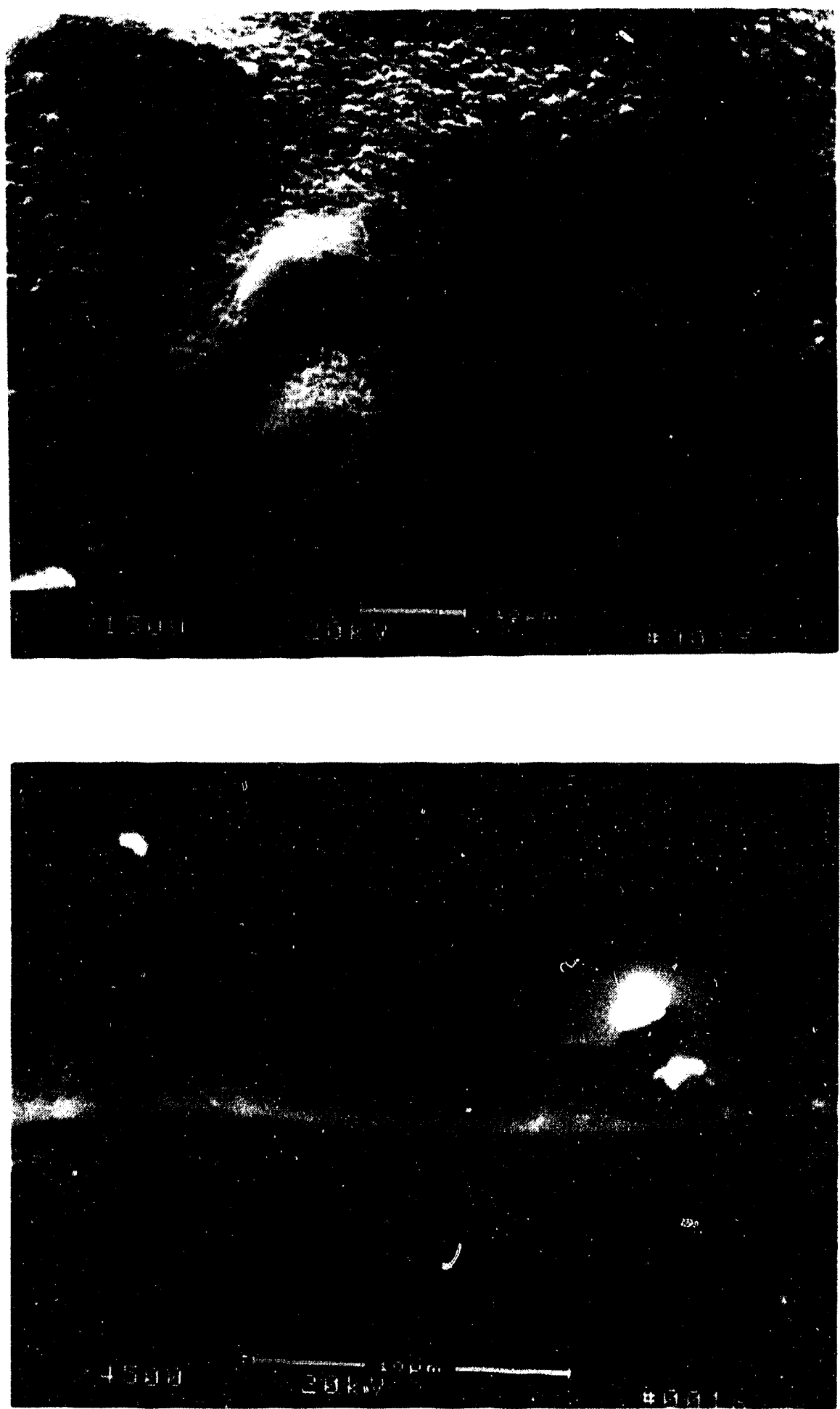

Figure 12b - Higher Magnification Yicrographs Of The Ligament And Interconnect Binder Phase In The CrBC-Exposed Schumacher Dia Schumalith P40 Matrix 


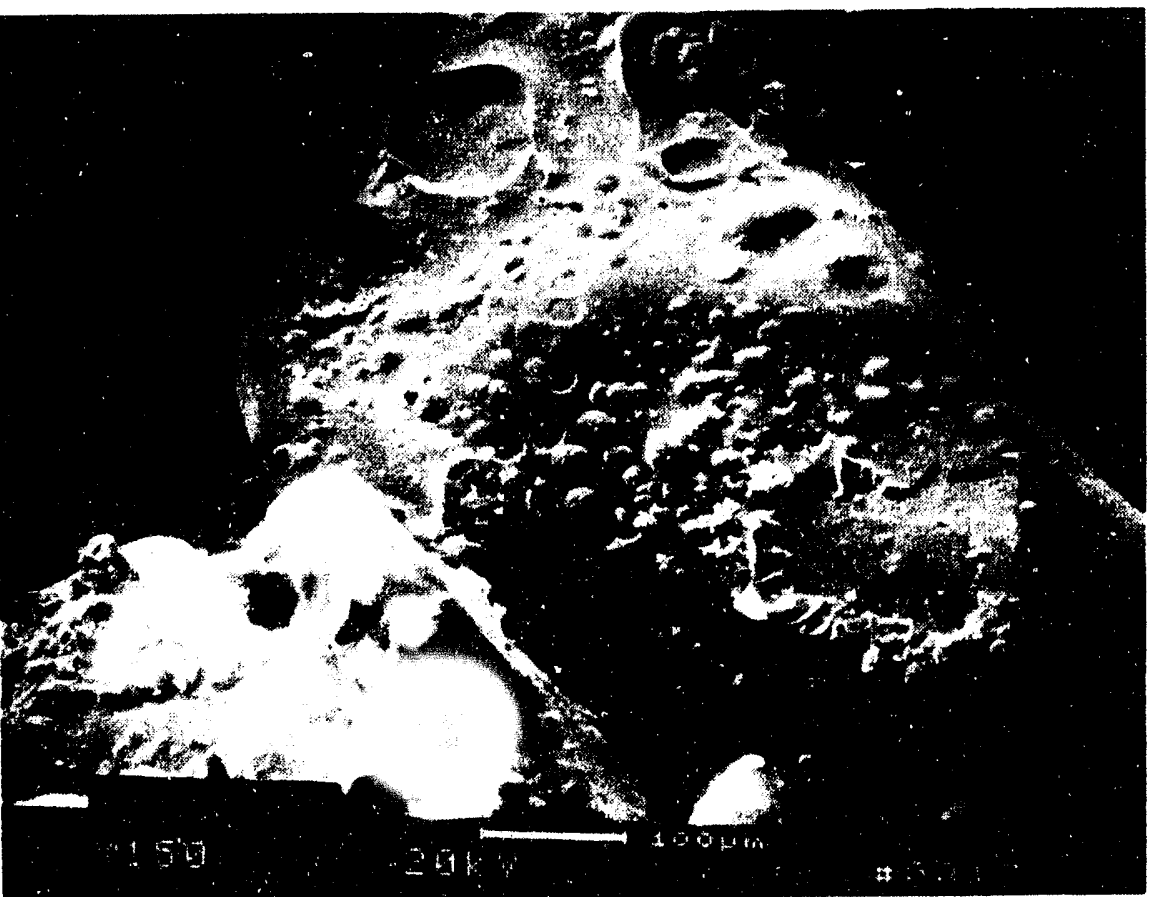

Figure 13 - Blister-Like Appearance Of The Binder Phase Which Coats Silicon Carbide Grains In The GrBC-Bxposed Schumacher Dia Schualith P40 Matrix 

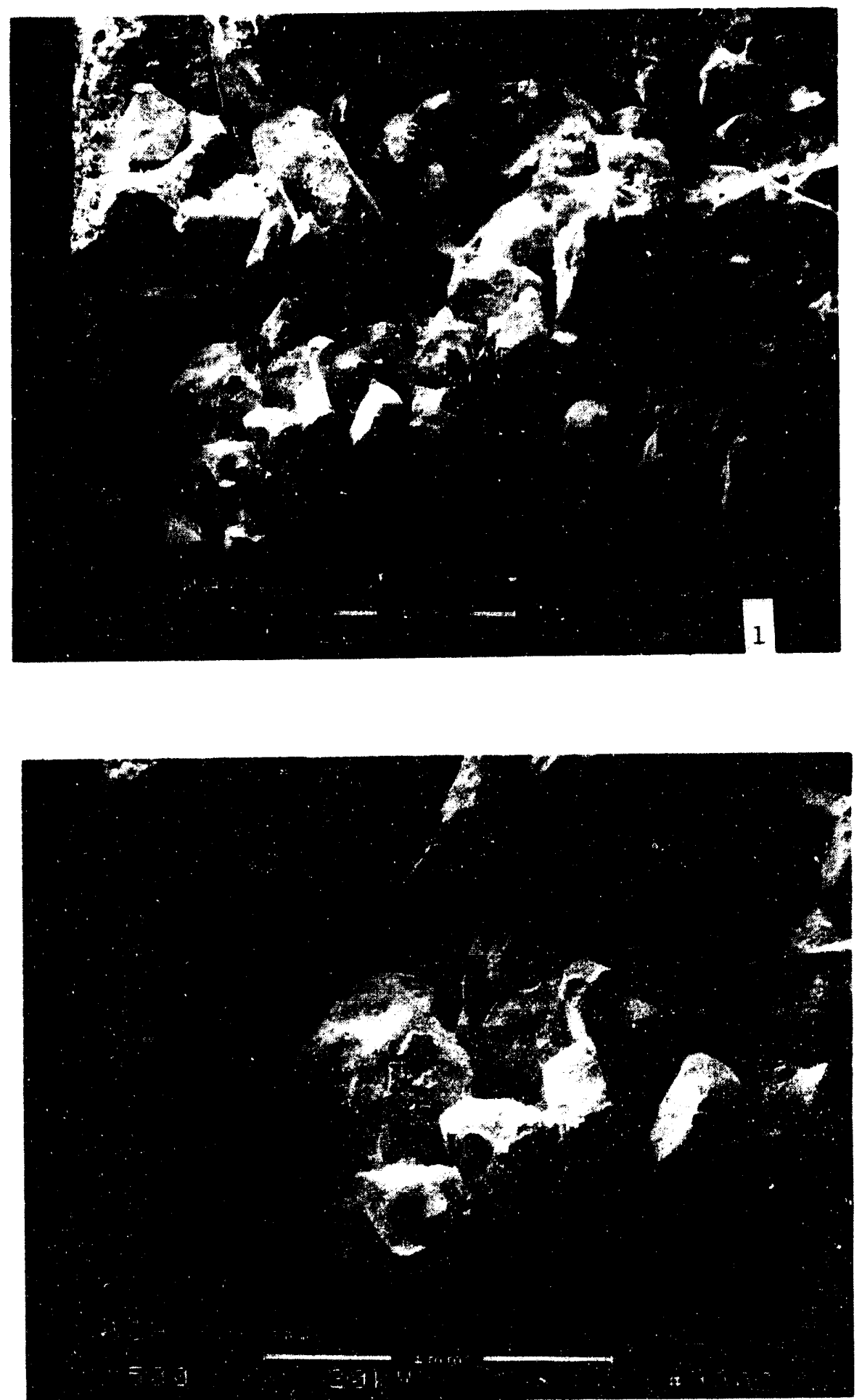

Figure 14a - Yicrographs Illustrating The Morphology of The Schumacher Dia Schumalith P40 Matrix After 227 Bours of Exposure In The $900^{\circ} \mathrm{C}$ CFBC Gas Bnvironment (Gold Costing Applied During Sample Preparation) 

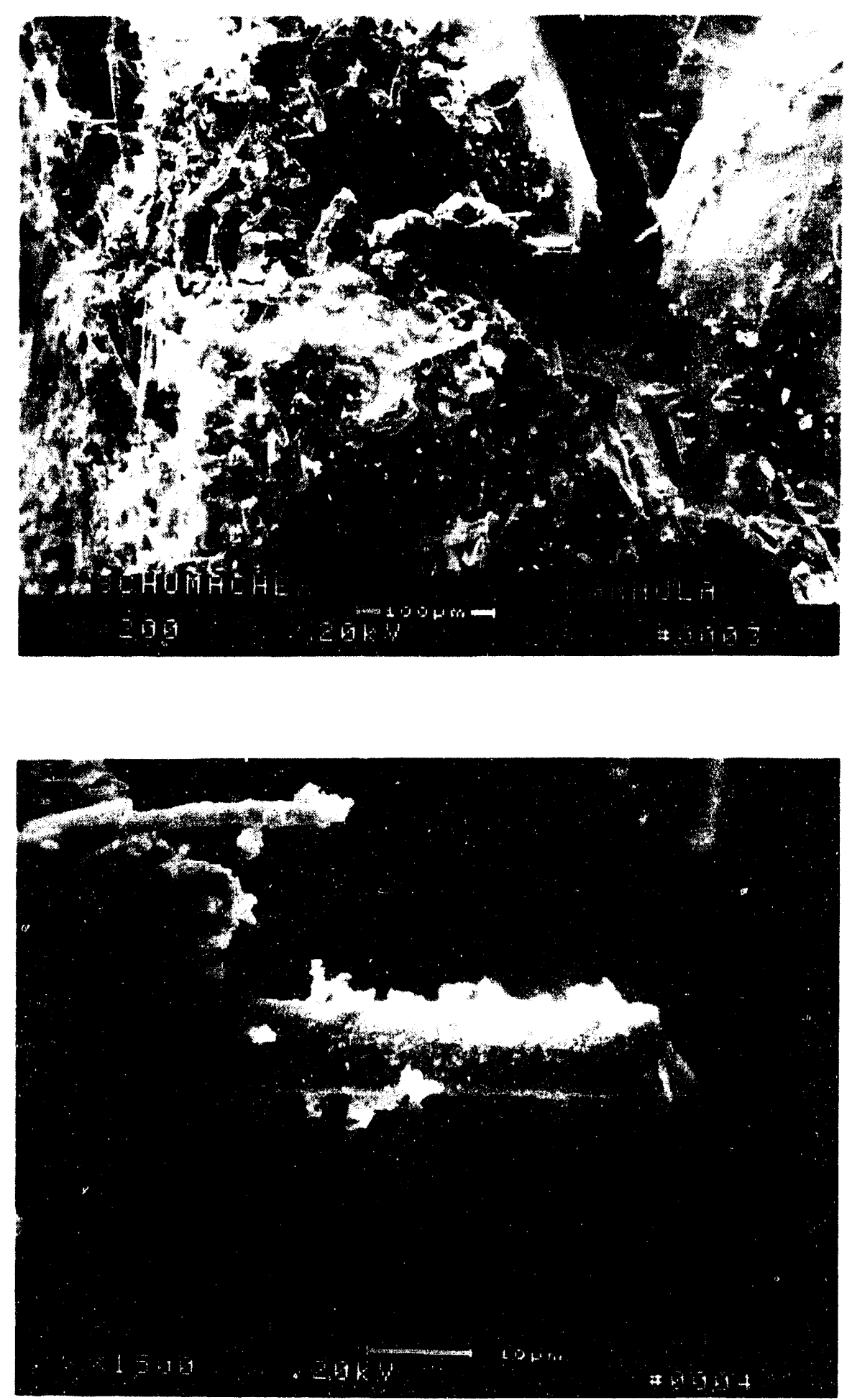

Pigure 14b - Higher Magnification Micrographs Detailing The Norphology of The Pibrous OD Yenbrane And Its Attachnent To The First Underlying Support Silicon Carbide Grain 


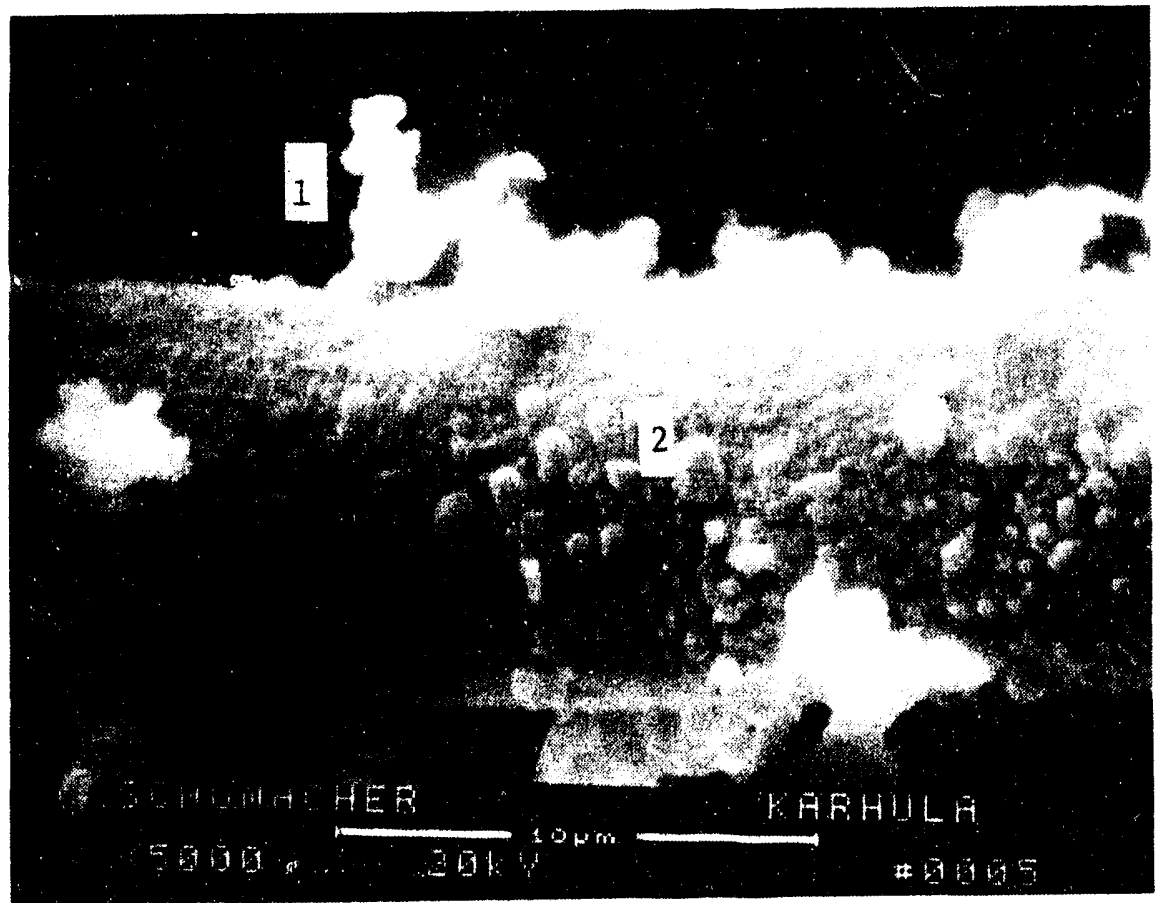

Figure 14c - High Magnification Micrograph Detailing The Morphology of The Ribers In The Schumacher Dia Schumalith F40 OD Membrane After 227 Hours $0 f$ Exposure In The CFBC Gas Environment 

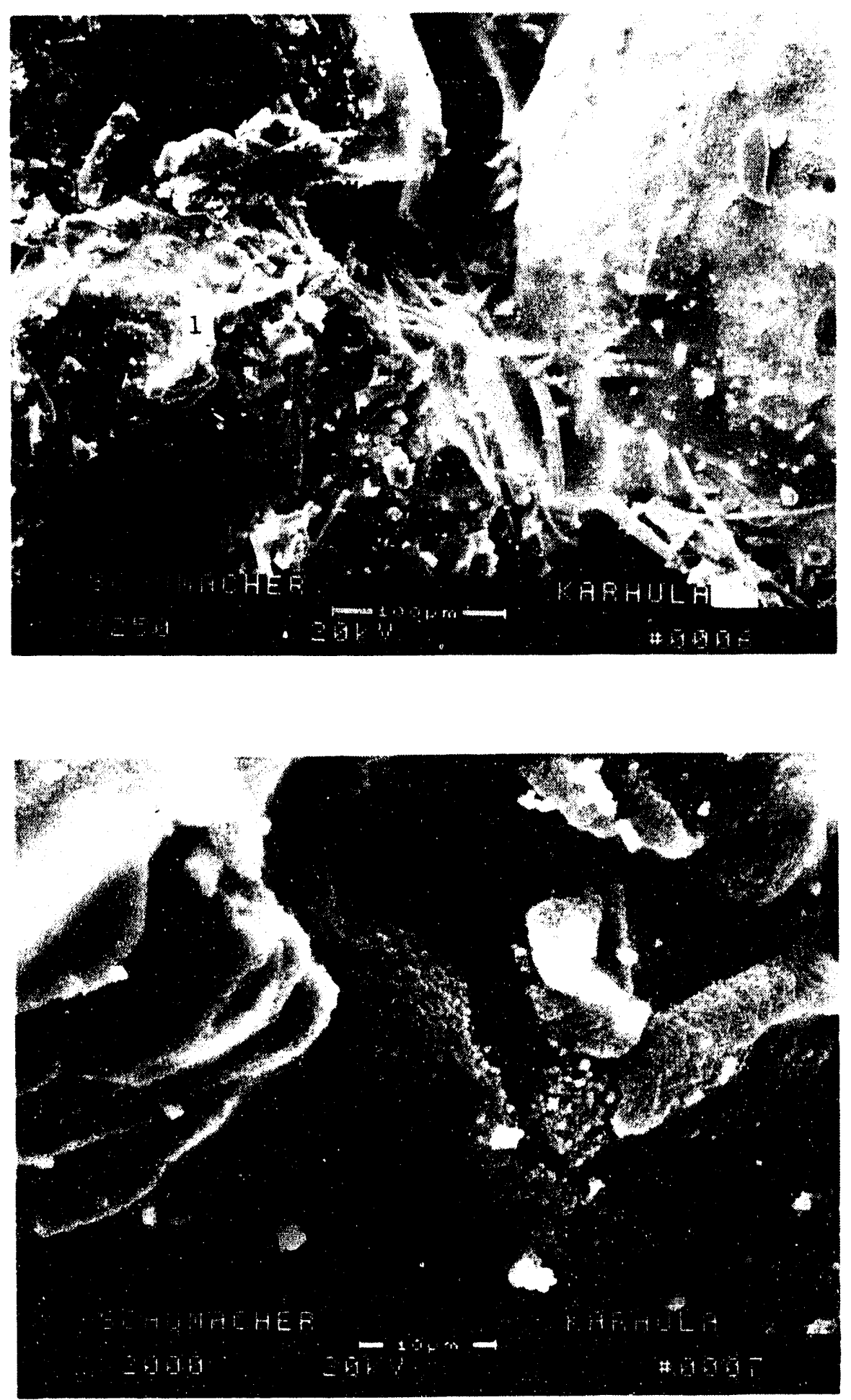

Figure 15a - Micrographs Illustrating Phase Transformations Along The Binder Which Coats The Silicon Carbide Grains In The CFBC-Exposed Schunacher Dia Schunalith F40 Filter Matrix 


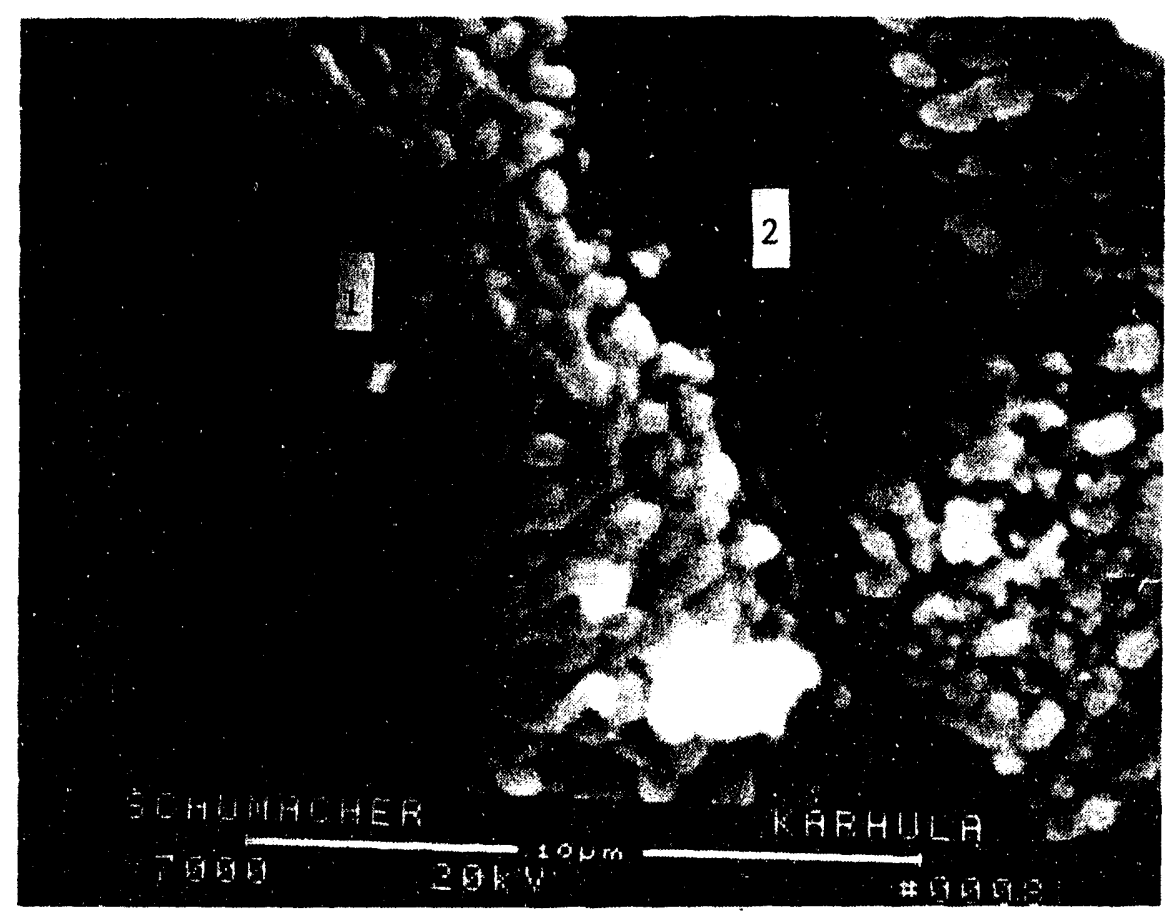

Figure 15b - Higher Magnification Micrograph Illustrating Phase Changes (Cryatallization) In The Binder Coating of The CFBC-Exposed Schumacher Dia Schumalith F40 Filter Matrix 
the mat-like formation shown in Area 1, Photo 8, Figure 15b indicates the presence of $51.03 \% 0,46.42 \% \mathrm{Si}$, and $2.55 \% \mathrm{Al}$, while the surrounding binder phase in Area 2, Photo 8, Figure 15b consists of $31.49 \% 0,61.61 \%$ $\mathrm{Si}, 4.38 \% \mathrm{Al}$, and $2.52 \% \mathrm{~K}$.

Figure 16 illustrates the extensive mat-like formation which results during coalescence (crystallization) of the binder phase in the CFBC-exposed clay bonded silicon carbide filters. Note the formation of holes in the binder, as well as rod-like features. EDAX analysis of the 1-2 $\mu \mathrm{m}$ nodules formed along the binder surface indicates the presence of 58.26\% $0,32.62 \% \mathrm{Si}, 8.50 \% \mathrm{Al}, 0.40 \% \mathrm{Fe}$, and $0.22 \% \mathrm{~K}$ (Area 1, Photo 13, Figure 16b). The rod-like features consist of $46.01 \% 0,38.94 \% \mathrm{Si}$, 12.77\% Al, 1.07\% Fe, 0.70\% K, and 0.51\% Ti (Area 2, Photo 13, Figure 16b).

The mat appearance of the binder phase is a surface effect which does not permeate through the ligament thickness of the binder between adjacent silicon carbide grains. This is evident by the smooth texture of the cross-sectioned ligament area shown in Area 1, Photo 16, Figure 17 (53.73\% Si, $34.05 \% \mathrm{O}, 7.74 \% \mathrm{Al}$, and $4.48 \% \mathrm{~K}$ ).

Photo 17, Figure 18 shows the surface of the silicon carbide grain which appears to have undergone debonding of the binder phase. Area 1 of Photo 17, Figure 18 is shown at higher magnification in Photo 18, Figure 18. The thickness of the binder in this area is approximately $10 \mu \mathrm{m}$. Note that the mat-like surface features of the binder phase do not extend into the cross-sectioned binder, or directly influence the binder-grain interface after 227 hours of exposure in the $800^{\circ} \mathrm{C}$, oxidizing CFBC gas environment. 

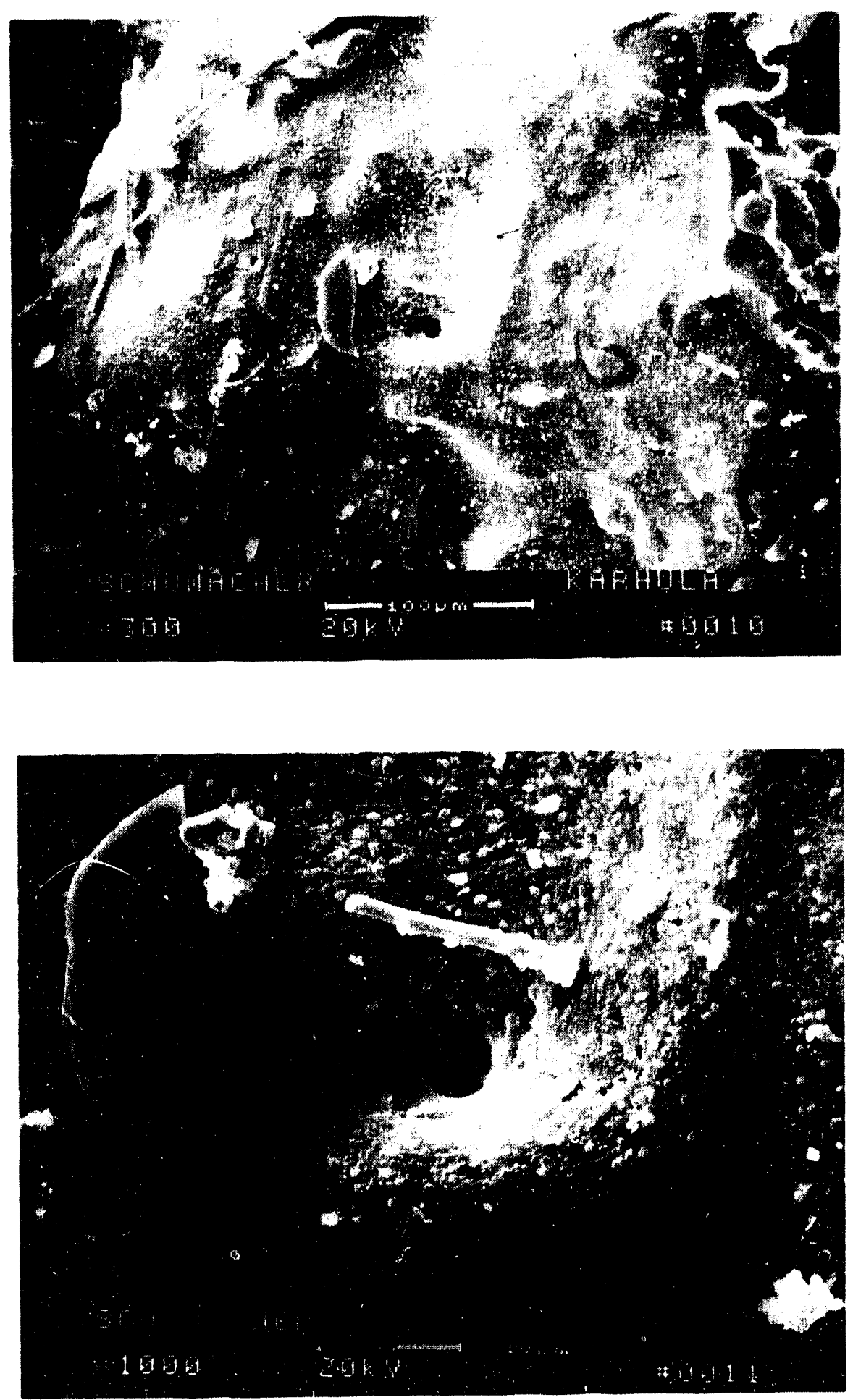

Figure 16a - Extensive Phas Transformations Along The Binder Surface of The CFBC-Exposed Schumacher Dia Schumalith F40 Filter Matrix 

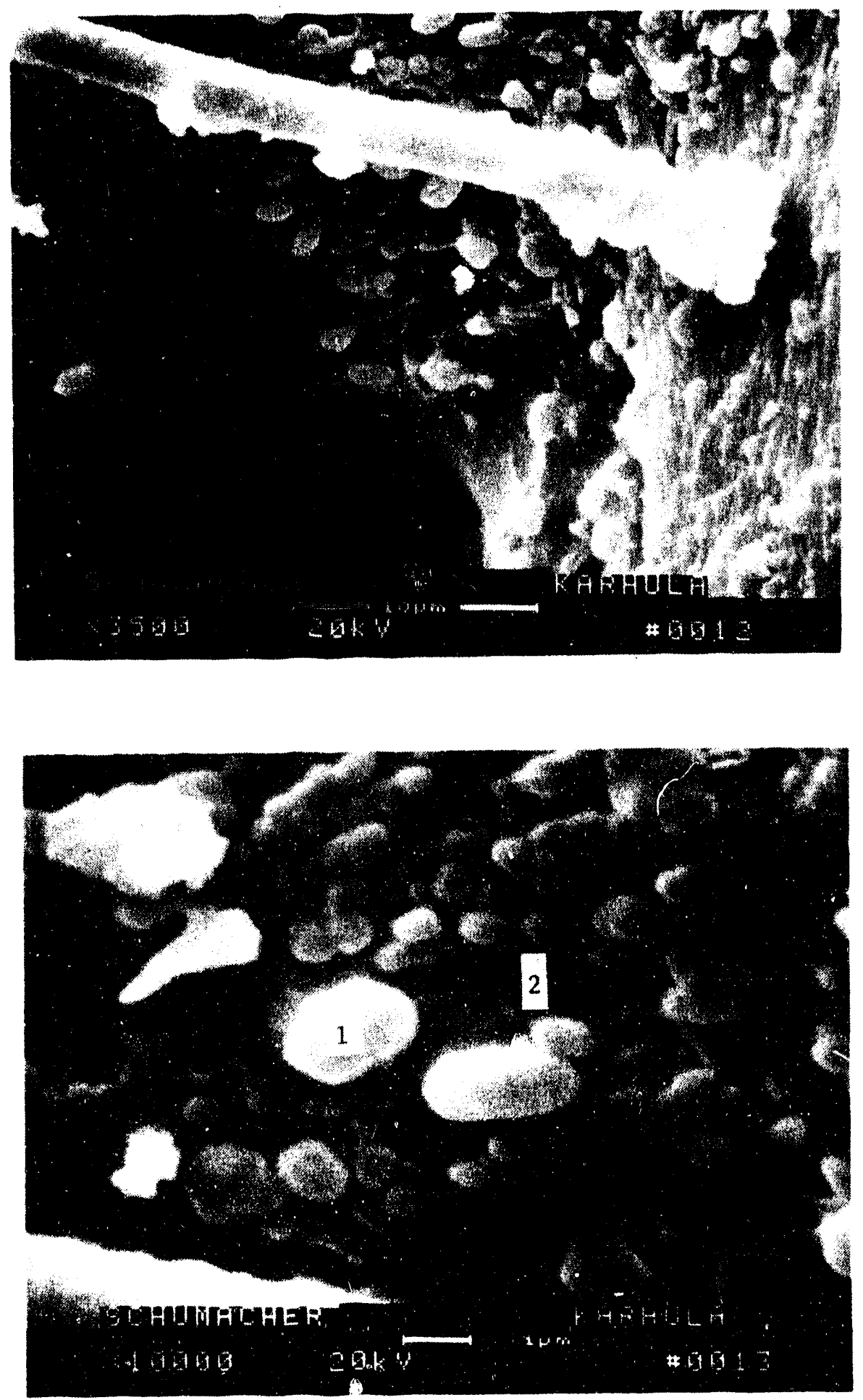

Figure 16b - Higher Magnification Of The Phase Changes That Occurred Along The Surface of The CFBC-Bxposed Schumacher Dia Schumalith F40 Filter Matrix 


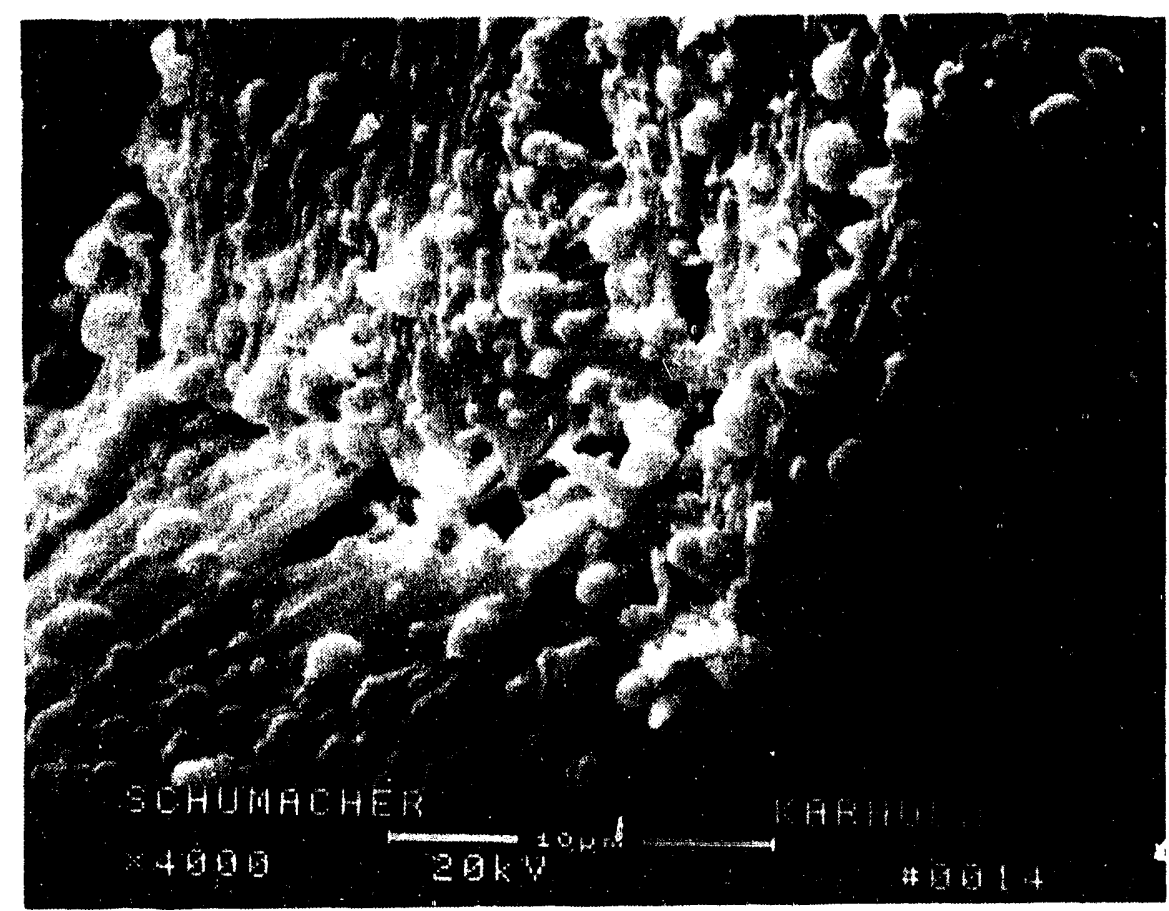

Figure 16c - Higher Magnification Of The Phase Changes That Occurred Along The Surface of The CFBC-Expcsed Schumacher Dia Schumalith F40 Filter Matrix 

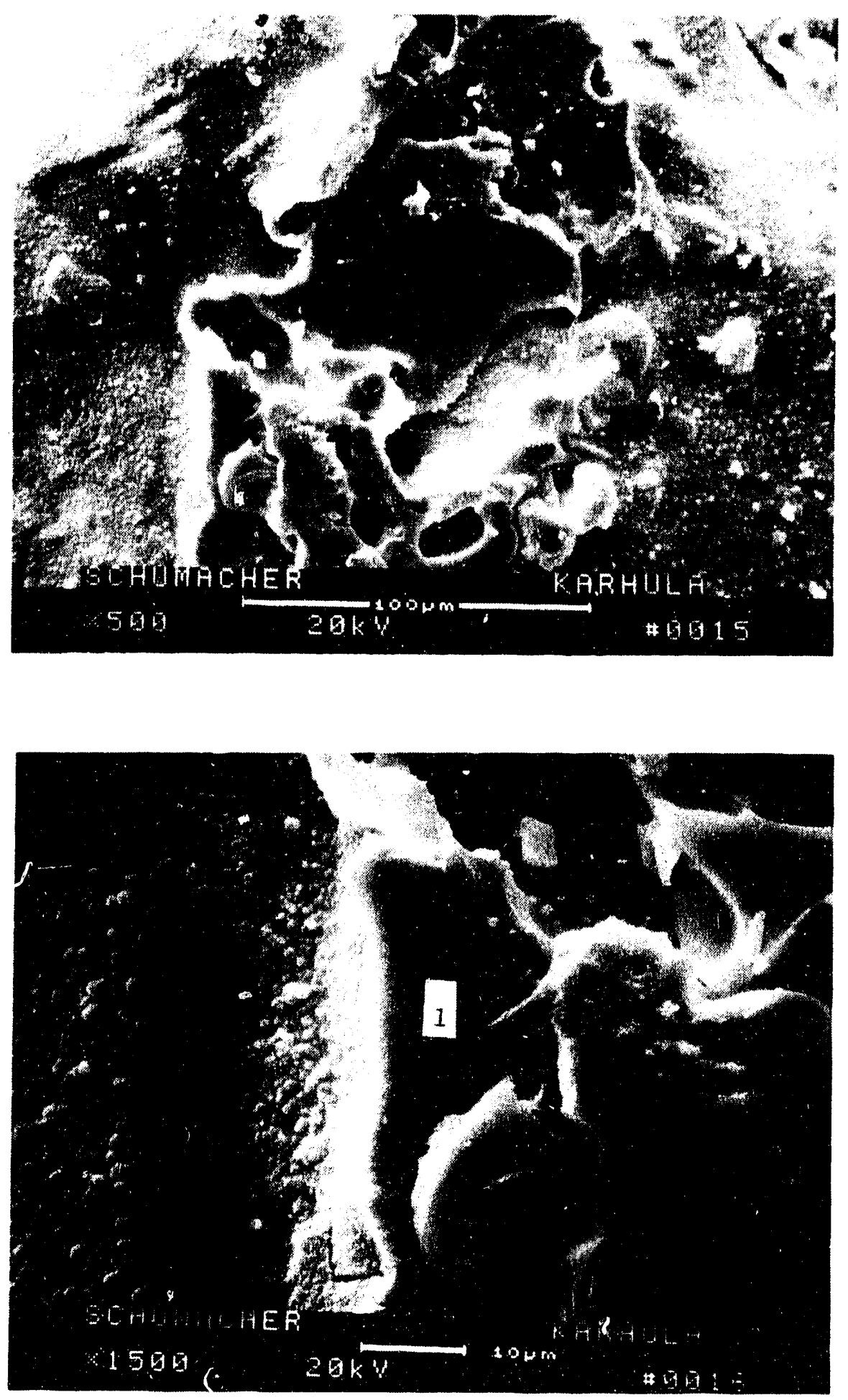

Figure 17 - Morphology of A Cross-Sectioned Binder Liganent Indicates That Phase Changes Occur Primarily Along The Surface Of The Silica-Enriched Matrix 

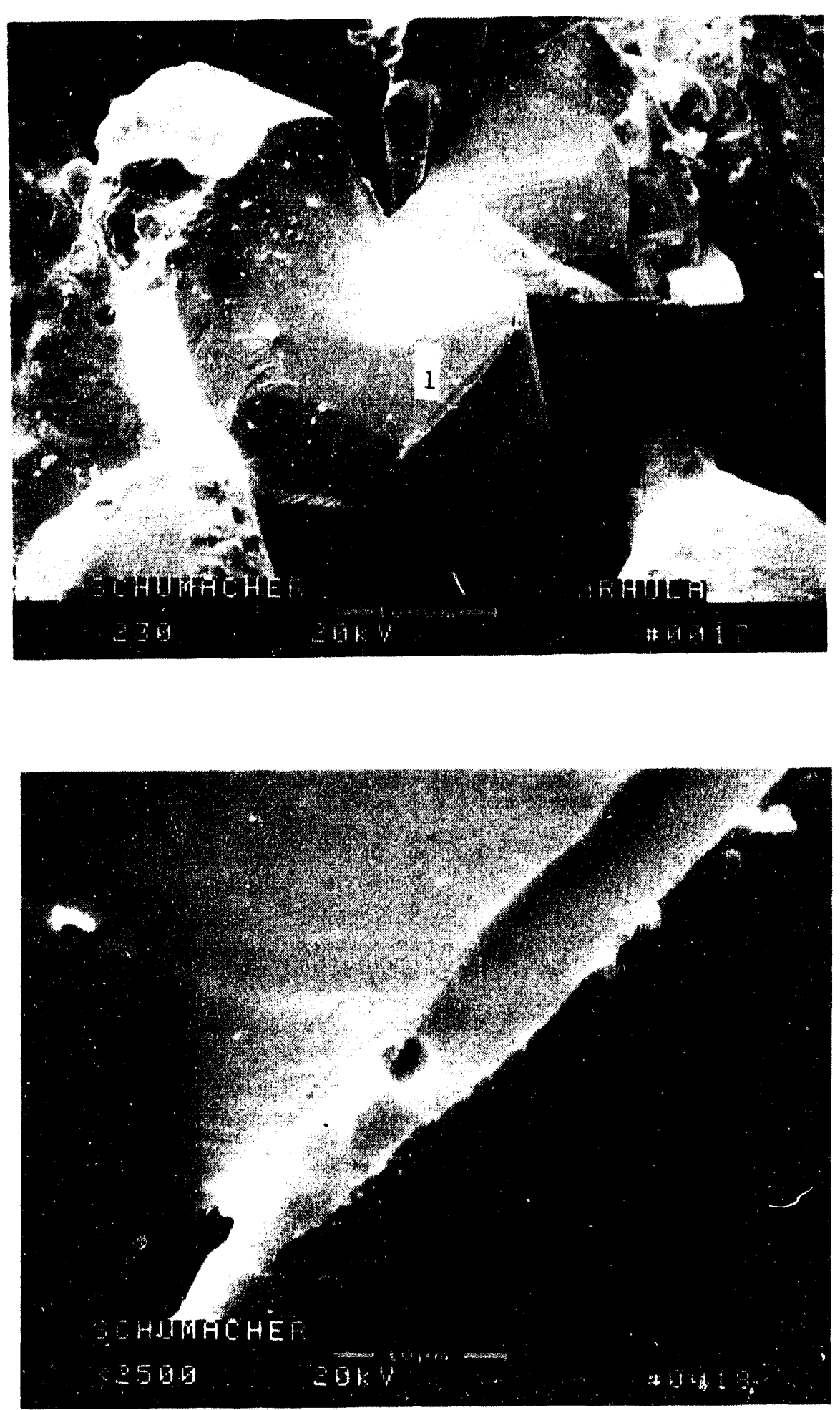

Figure 18 - Micrographs Illustrate The Thickness of The Binder Coating, And Surface Phase Changes That Result During Exposure of The Schuracher Dia Schumalith P40 Yatrix To The $900^{\circ} \mathrm{C}$ CFBC Gas Environment 
Frequently areas of the binder contain extensive phase transformations as show in Pigure 19. These areas are often associated with blistered or bubbled areas of the binder which are raised or have cracked, possibly due to outgassing from the underlying substrate.

Figure 20 illustrates the extensive mottling along the surface of the Schumacher Dia Schumalith F40 binder surface. Holes and depressions, as well as cracked and raised blister formations are also evident. The mottled rounded nodular features of the binder appear to be raised above the original binder surface (Figure 20b). The nodule shown in Area 1, Photo 24, Figure 20b consists of $64.29 \%$, 25.60\% Si, $8.26 \% \mathrm{Al}, 0.80 \% \mathrm{Na}, 0.58 \% \mathrm{Fe}$, and $0.37 \% \mathrm{~K}$.

Yoving several grains below the OD fibrous outer membrane, similar blisters and mat-like formations are evident in the Schumacher Dia Schumalith F40 matrix (Figure 21). The binder ligament area shown in Area 1, Photo 27, Figure 21b consists of $52.81 \% \mathrm{O}, 37.56 \% \mathrm{Si}, 4.76 \%$ Al, 2.24\% K, 2.10\% $\mathrm{Na}$, and 0.53\% Ti.

Peeling and removal of the binder layer is evident in Photo 28, Figure 21b, and at higher magnification in Figure 21c. The smooth binder ligament shown in Area 1, Photo 29, Figure 21c contains $53.17 \% 0$, $42.02 \% \mathrm{Si}, 2.32 \% \wedge 1,1.60 \% \mathrm{Na}, 0.84 \% \mathrm{~K}$, and $0.34 \% \mathrm{Ti}$. The mottled area shown in Area 2, Photo 29, Figure 21c is shown at higher magnification in Area 1, Photo 30, Figure 21c. The composition of the mottled area contains $53.87 \% \mathrm{Si}$ and $46.13 \% \mathrm{O}$ (carbon is also present) which implies the formation of a thin oxide layer along the surface of the silicon carbide grain.

Yoving approximately $10 \mathrm{~mm}$ from the OD fibrous membrane (i.a., $5 \mathrm{~mm}$ from the ID surface) we see further blistering and cracking, as well as outgassing of the binder coating along the Schumacher Dia Schumalith F40 silicon carbide grains (Figure 22). Debonding of the 

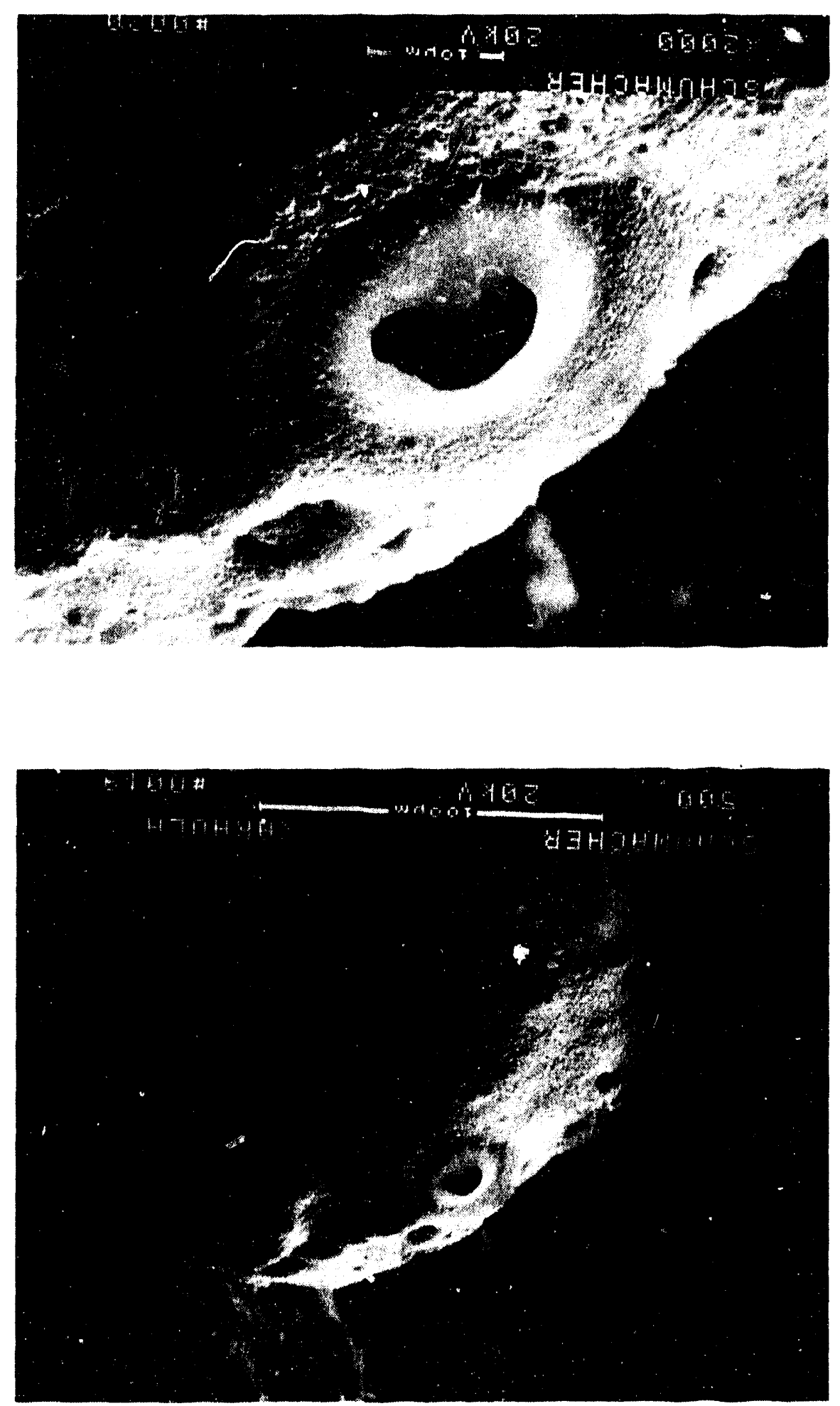


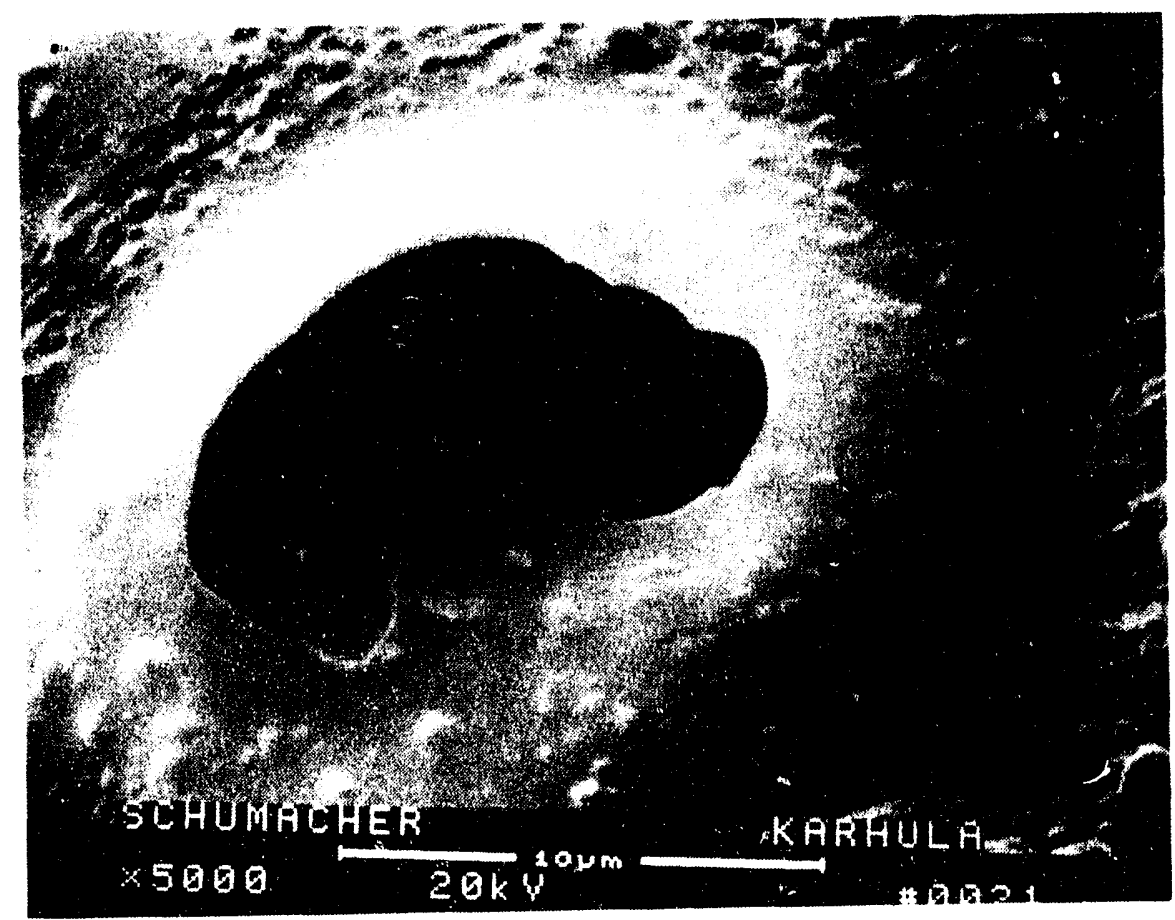

\section{Figure 19b - High Magnification Micrograph Detailing The Presence of Cracks In The Blister Formations That Result Along The Schumacher Dia Schumalith F40 Binder Surface After 227 Hours of Operation In The CFBC Gas Environment}



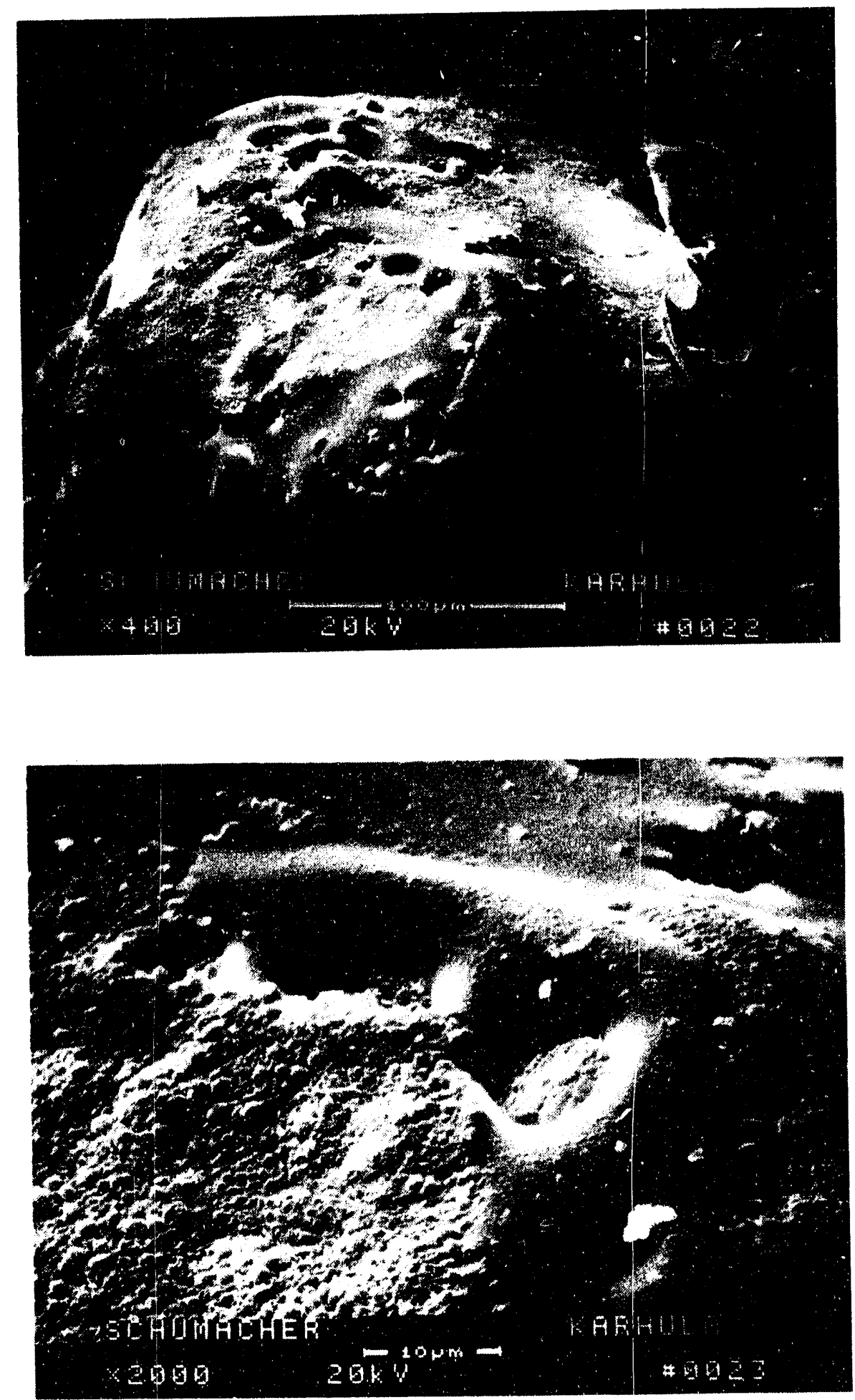

Figure 20a - Micrographs Illustrating The Extensive Nottling of The Schumacher Dia Schumalith F40 Binder Surface After Exposure To The CFBC Gas Environment 


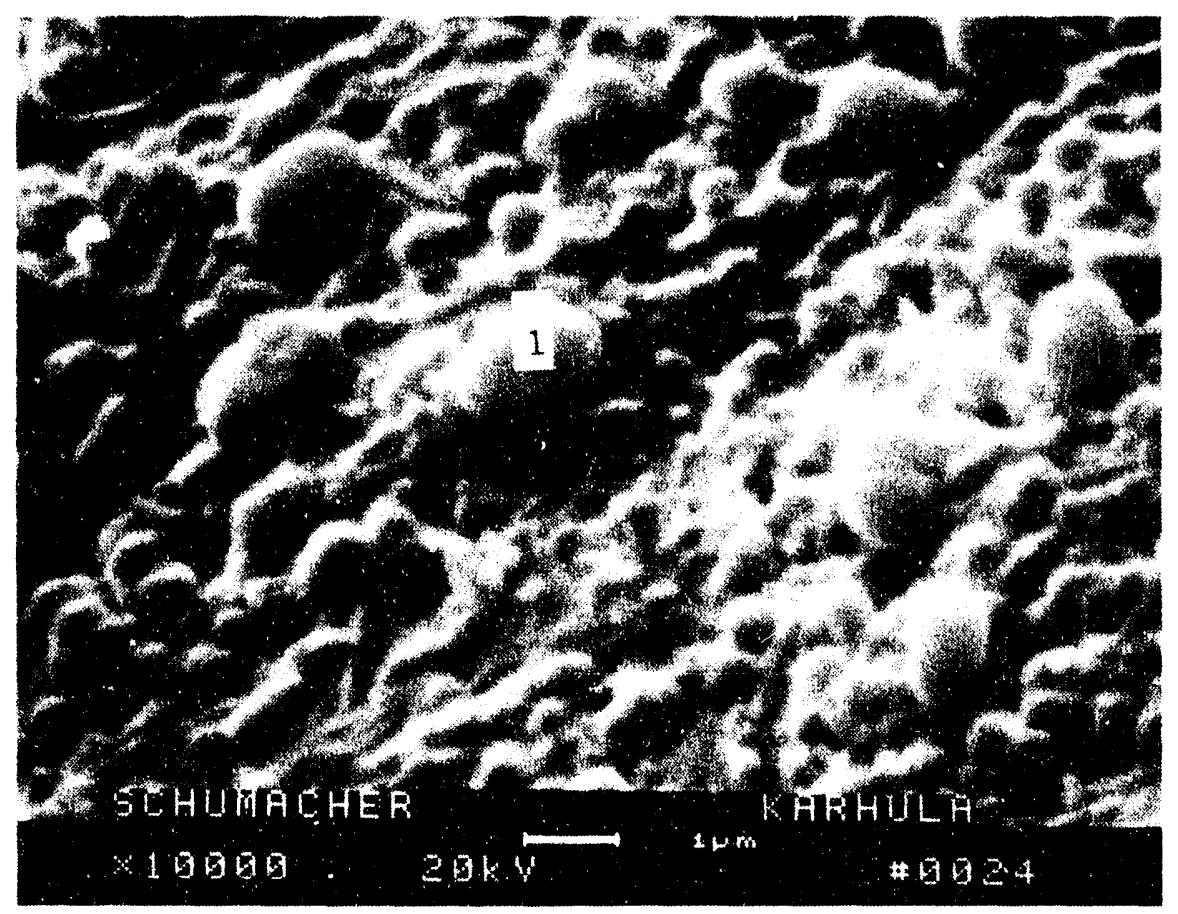

Figure 20b - Bigher Magnification Micrograph Illustrating The Morphology Of The Schumacher Dia Schumalith F40 Binder Surface After Exposure To The CFBC Gas Environnent 

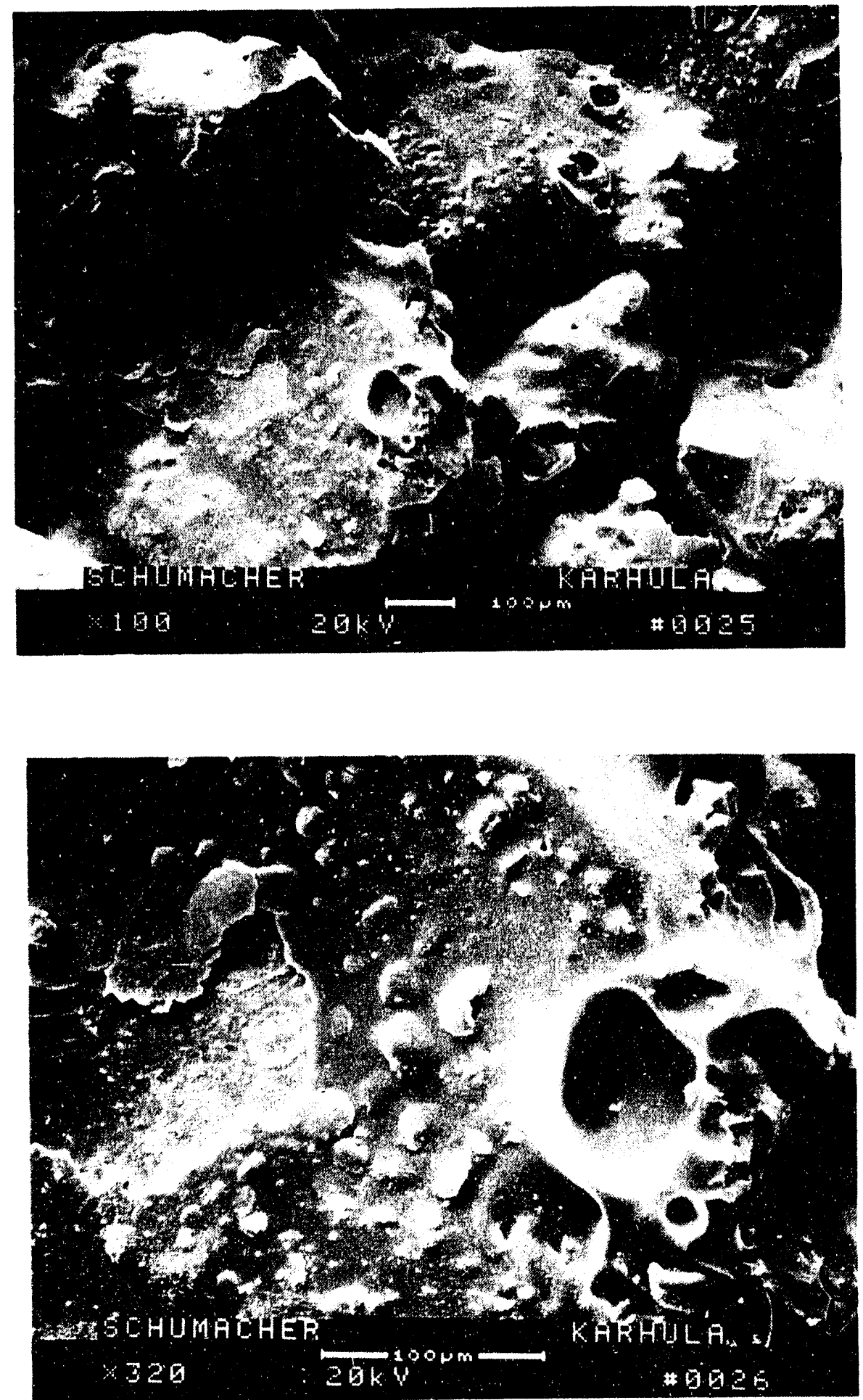

Figure 21a - Blistering And Debonding of The Binder Surface Along Silicon Carbide Grains In The Schunacher Dia Schumalith F40 Filter That Was Bxposed To CFBC Operating Conditions 

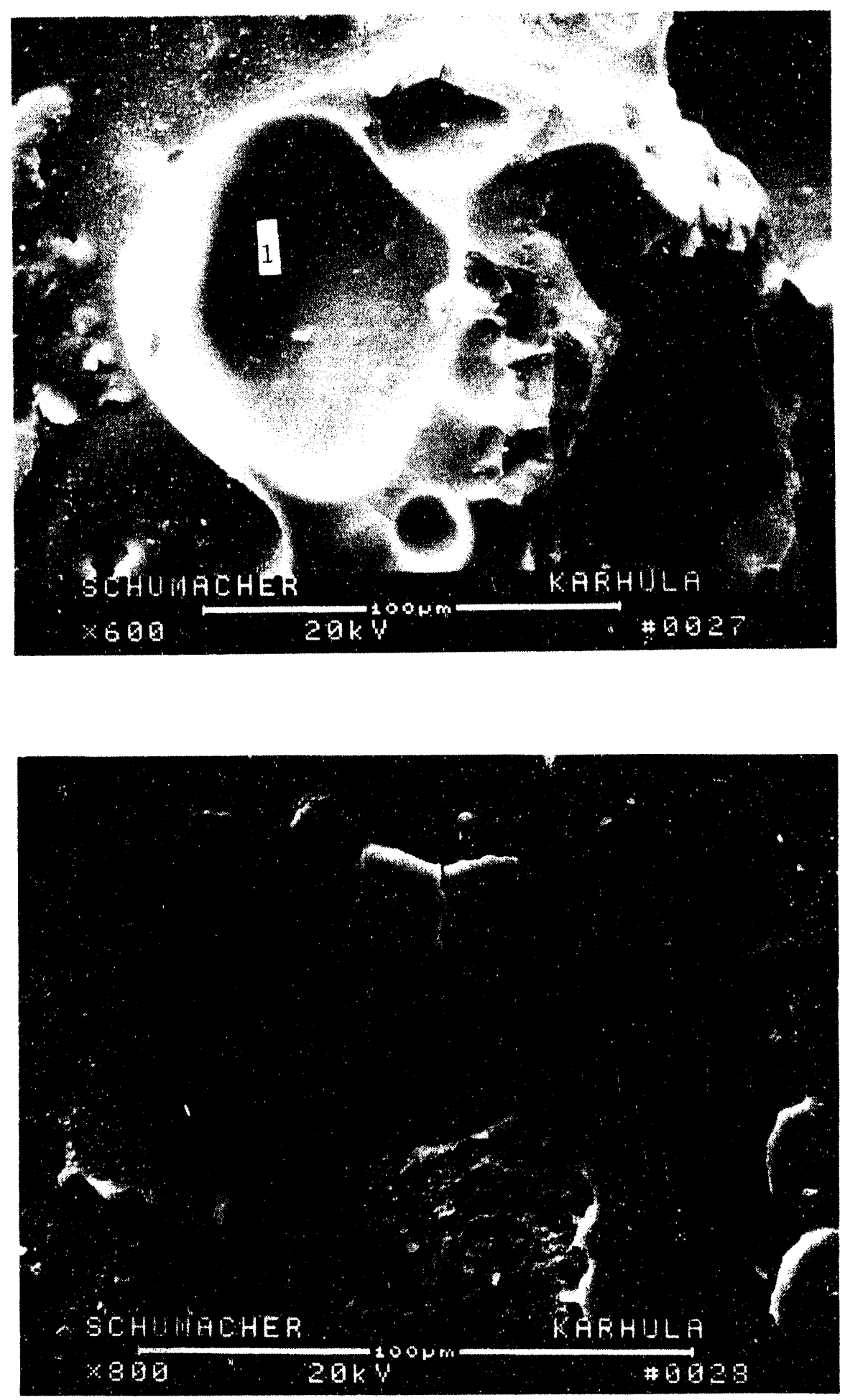

Figure 21b - Higher Magnification Micrographs Illustrating The Crack Formations And Debindered Areas of The Clay Bonded Silicon Carbide Schumacher Dia Schumalith P40 Pilter Matrix 

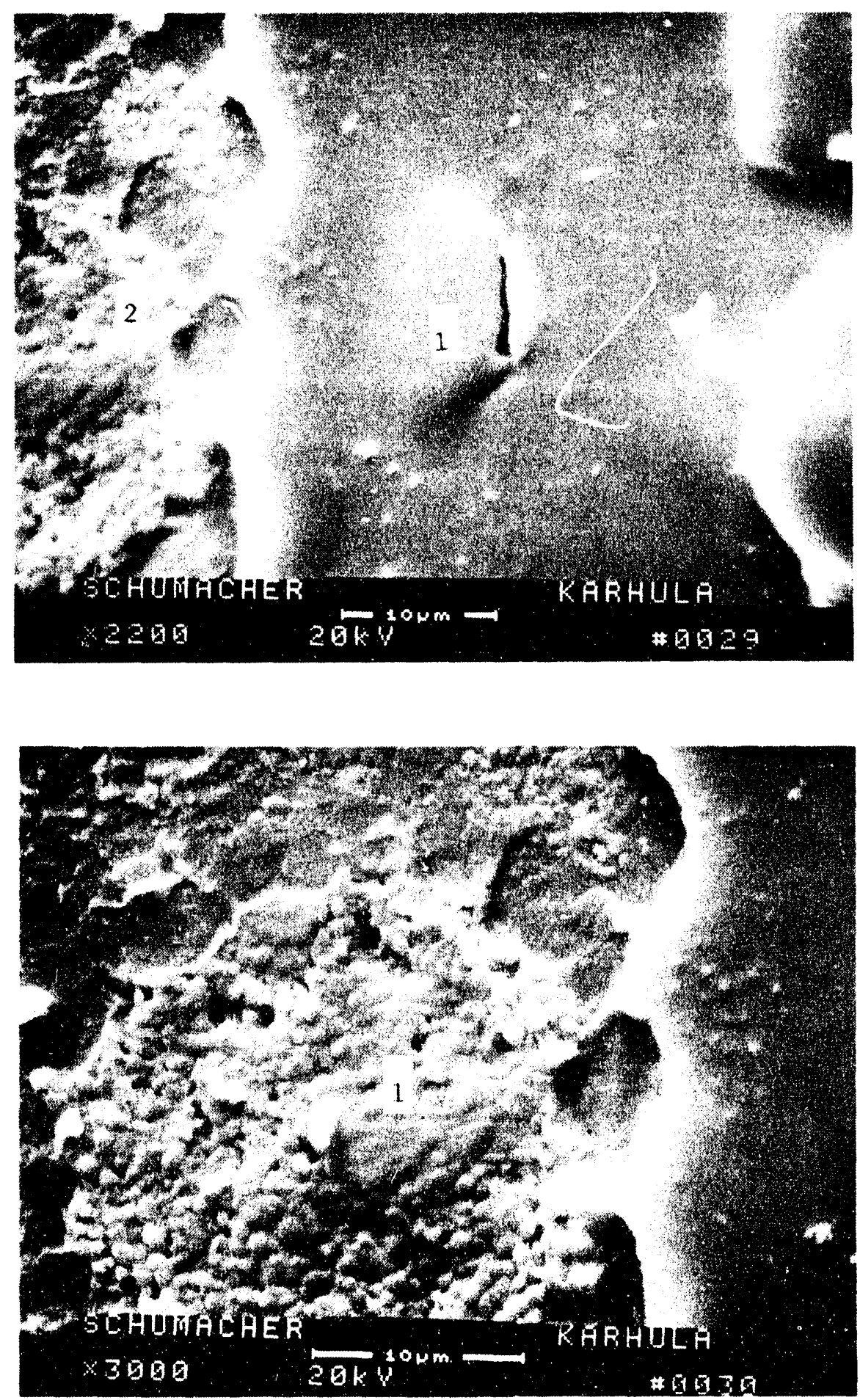

Figure 21c - Higher Magnification Micrographs Showing Both The Binder Coating And An Ares Which Contains A Thin Layer of A Silica-Containing Phase Along The Silicon Carbide Grain Surface 

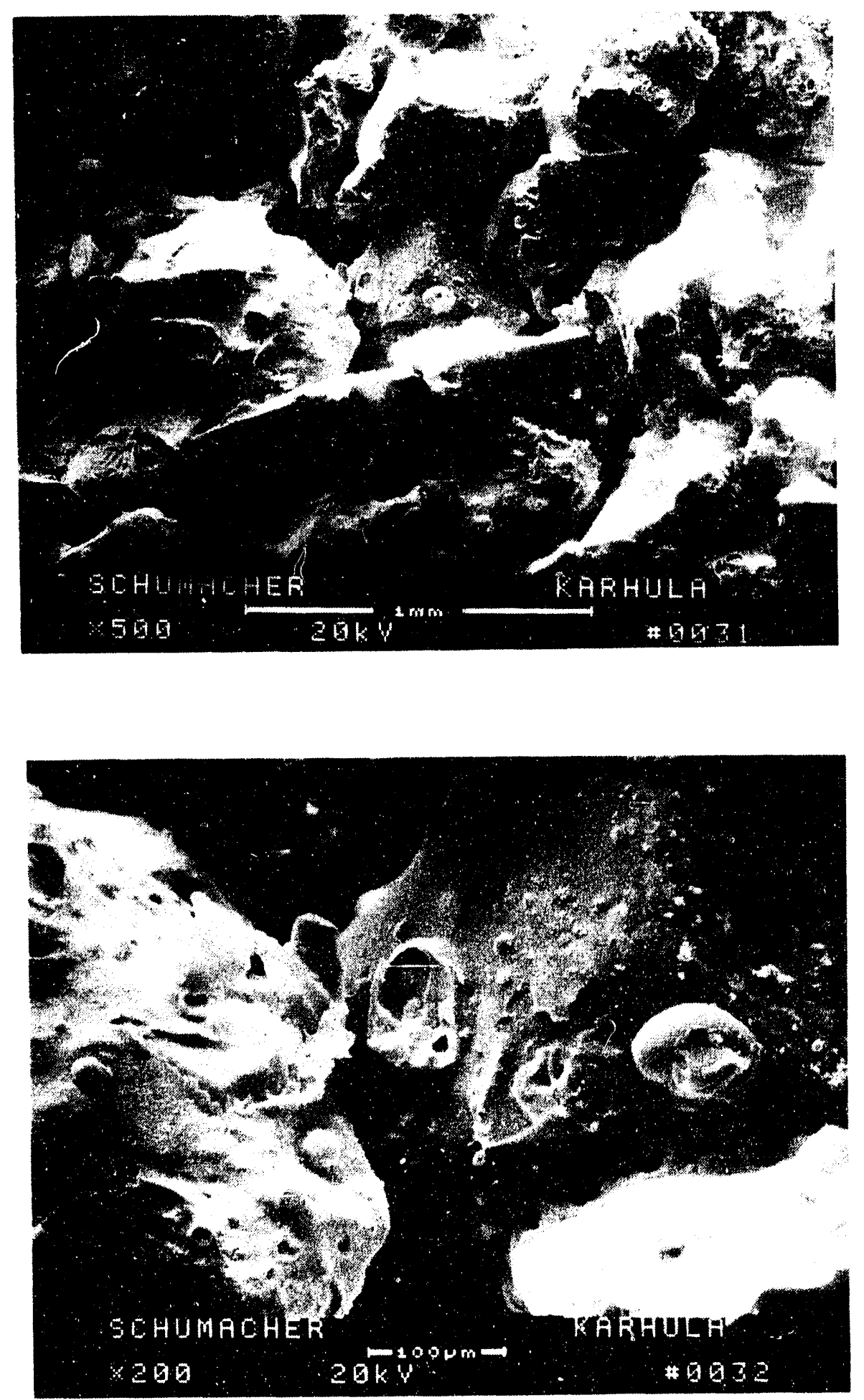

Pigure 22a - Yorphology of The Clay Bonded Silicon Carbide Schumacher Dia Schumalith F40 Candle Filter Matrix At Approximately $10 \mathrm{~mm}$ From The OD Surface Of The GPBC-Bxposed Candle Filter 

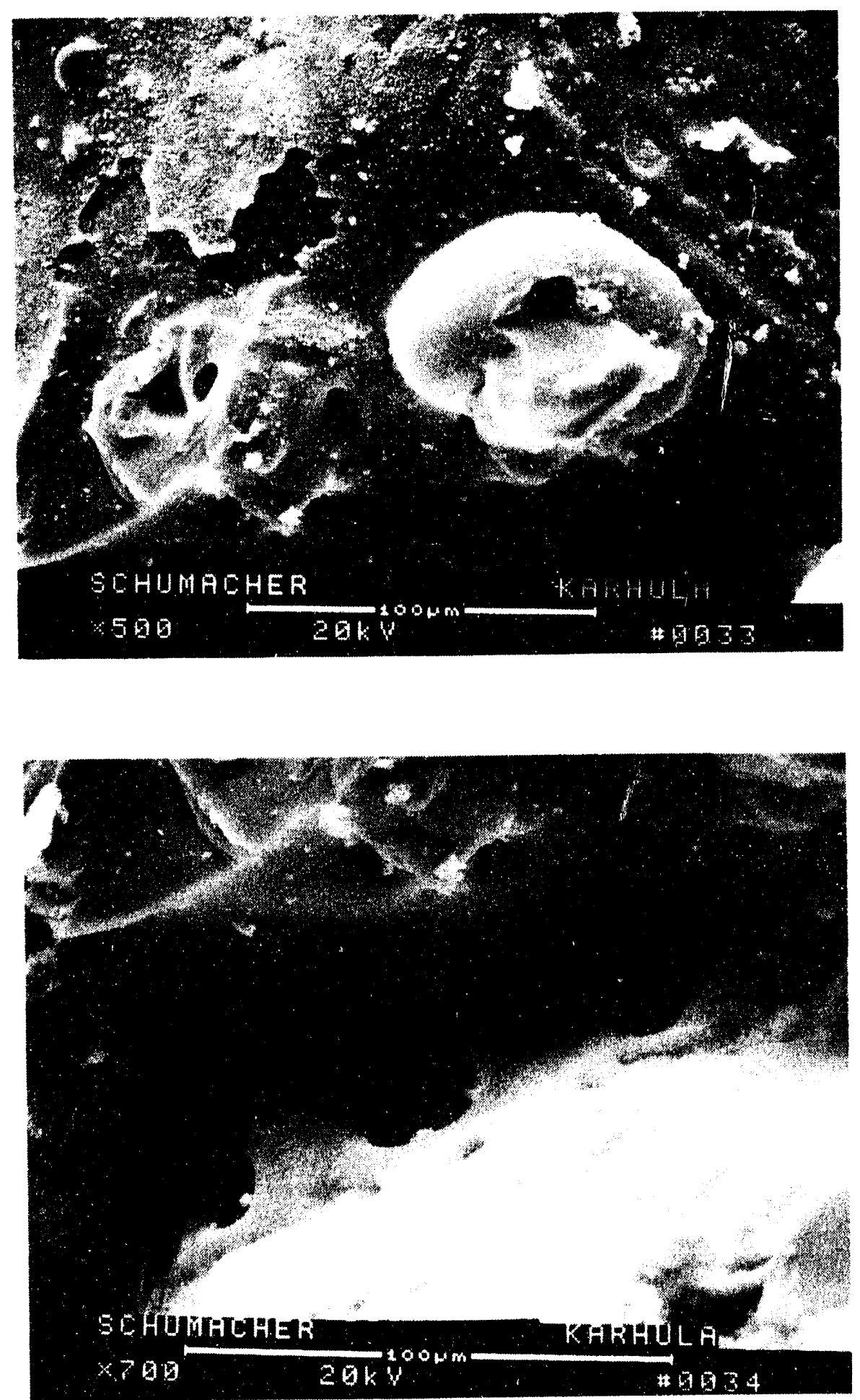

Figure 22b - Micrographs Illustrating Debonding And Cracking of The Binder Phase In The Schumacher Dia Schunalith F40 CFBCExposed Candle Filters 


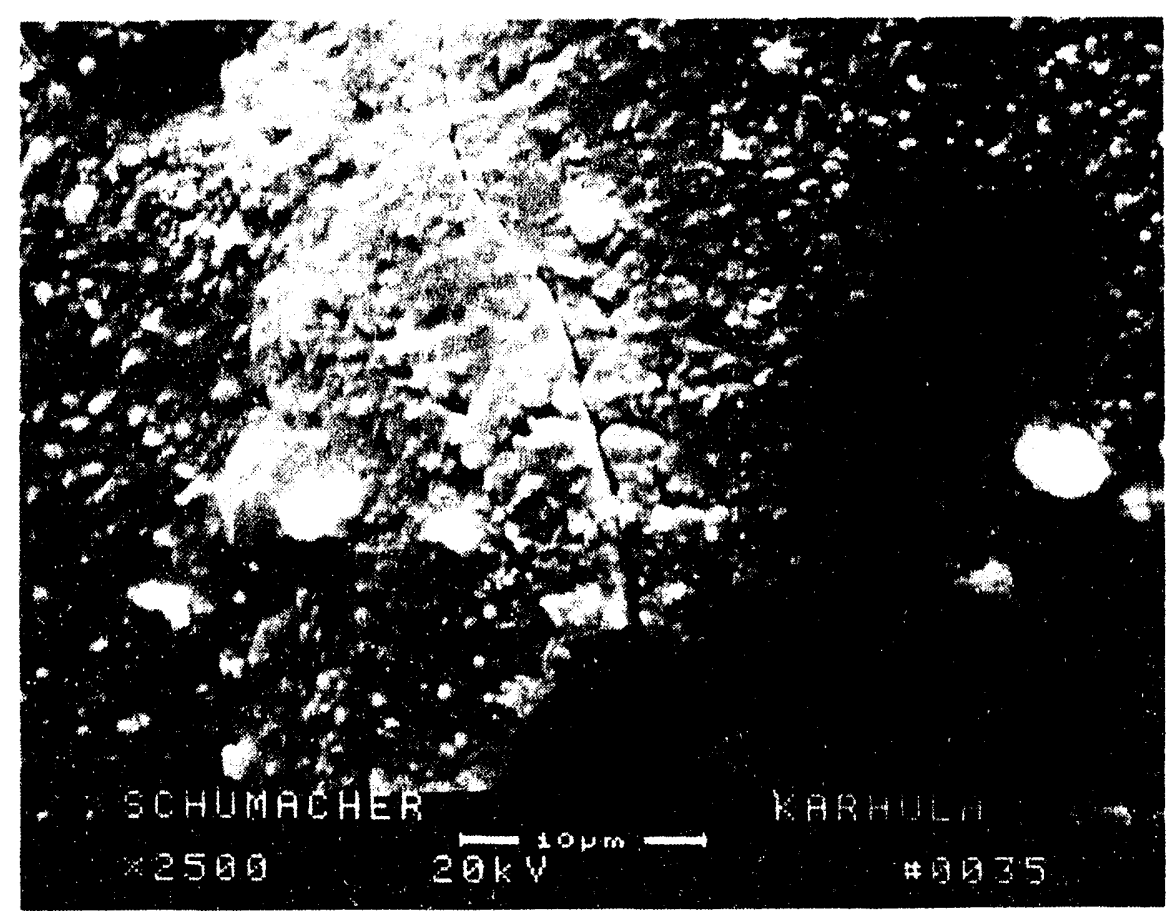

Figure 22c - Presence Of Microcracks Along The Mat-Like Formations of The Binder Phase Which Coats The Schunacher Dia Schumalith P40 Silicon Carbide Grains 
binder and crack formations, as well as the formation of the nodular mat-like binder surface features are also evident. The extensive formation of the mat-like binder surface phase is shown in Figure 23. The mat (Area 1, Photo 37, Figure 23) consists of $50.85 \%$ 0, 45.23\% Si, and $3.92 \% \mathrm{Al}$. The smooth underlying substrate shown in Area 2, Photo 37, Figure 23 consists of silicon and carbon, indicating the location of the silicon carbide grain. Oxygen was not detected along the silicon carbide grain surface shown in Area 2, Photo 37, Figure 23.

At approximately $1.5 \mathrm{~mm}$ from the ID surface of the Schumacher Dia Schumalith F40 clay bonded silicon carbide filter matrix, we see that the pore channels are frequently filled with fines (Figure 24). The fines were forced back into the filter matrix during pulse gas cleaning once failure in the ten alumina/mullite candle filters had occurred. Note the relatively large (20-30 $\mu \mathrm{m})$ agglomerate of fine particulates which were deposited and retained along the binder surface of the silicon carbide grains.

Figure 25 shows the adherence of fines along the binder coating of the silicon carbide grains at an alternate location which was approximately $1.5 \mathrm{~mm}$ from the candle filter ID surface. Frequently microcracks are evident along the binder coating which encapsulates the silicon carbide grains along the filter ID. The top micrograph shown in Photo 44, Figure 25b faintly illustrates the microcrack features. These have been redrawn in the bottom micrograph of Photo 44, Figure 25b to emphasize their existence. Higher magnification micrographs of the fines which adhere to the ID surface silicon carbide grains are shown in Figure 25c. The fines are identified to contain silicon, oxygen, aluminum, calcium, magnesium, sodium, potassium, titanium, and iron. 

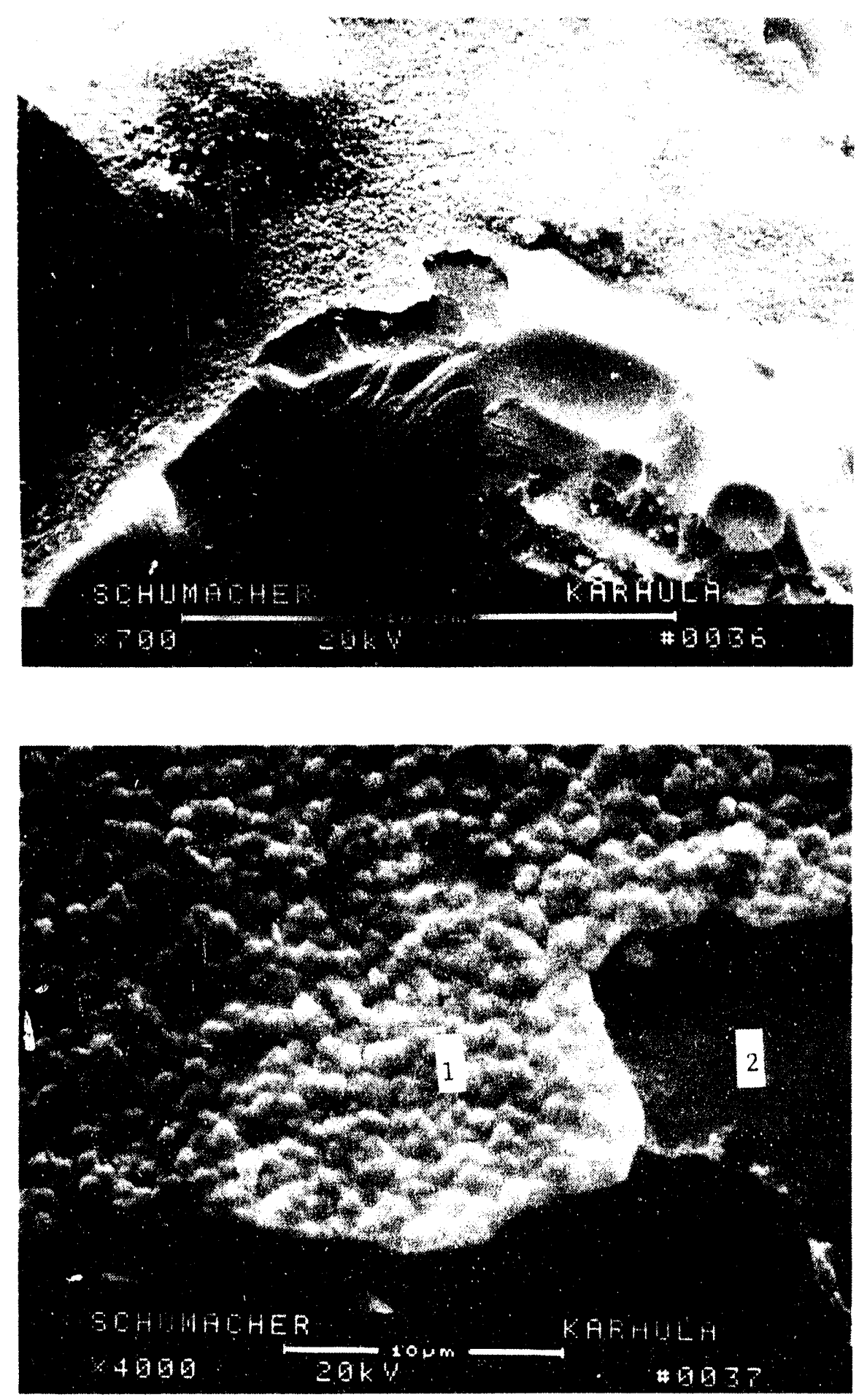

Figure 23 - Extensive Mat-Like Peature of The Crystallized Binder Phase Which Initially Coated The Silicon Carbide Grains In The Schumacher Dia Schunalith P40 Pilter Matrix 

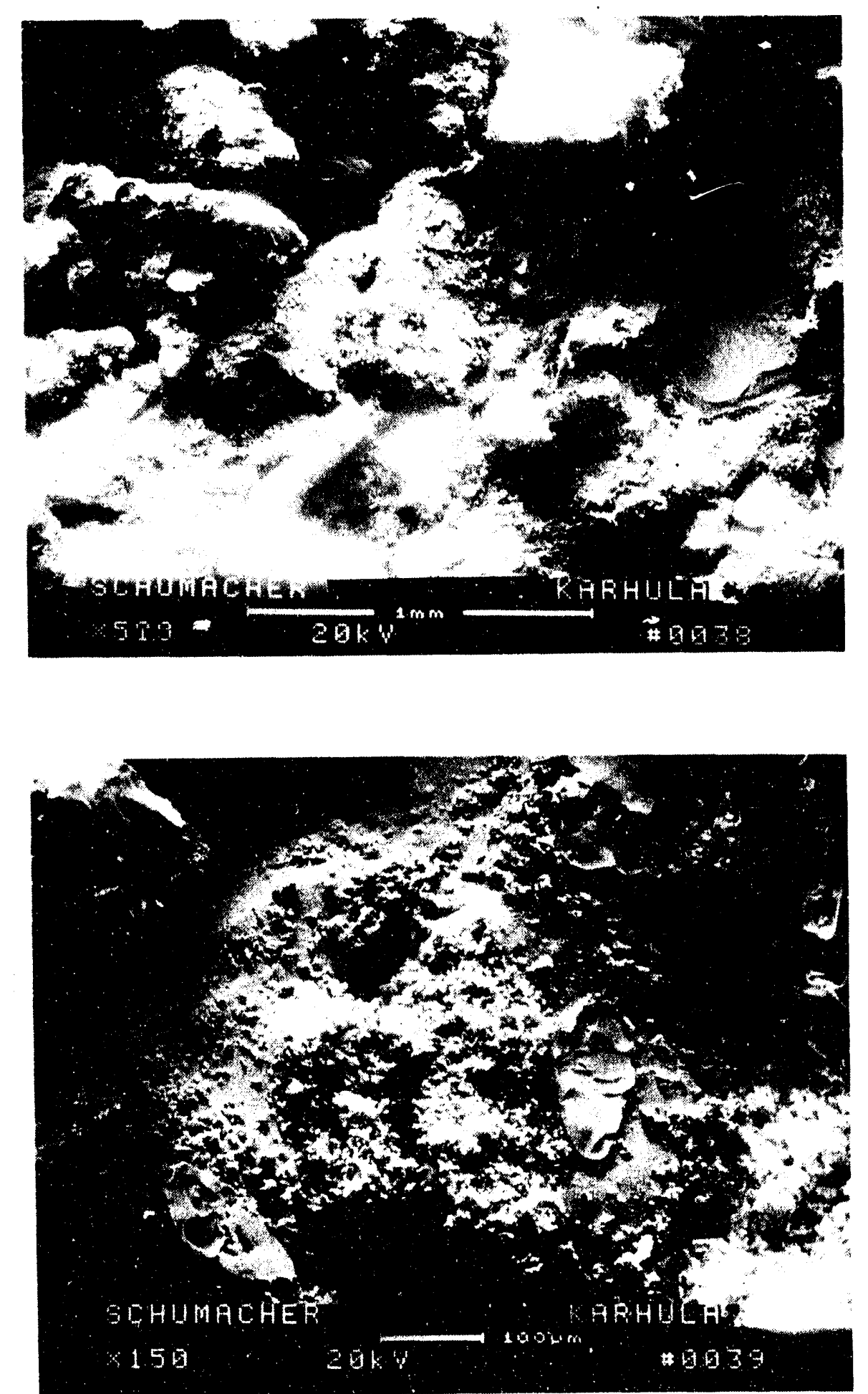

Figure 24a - Morphology of The Schunacher Dia Schunalith F40 Filter Matrix At Approximately 1.5 m Pron The Candle Filter ID Wall. Fines Are Present In The Pore Channels. 

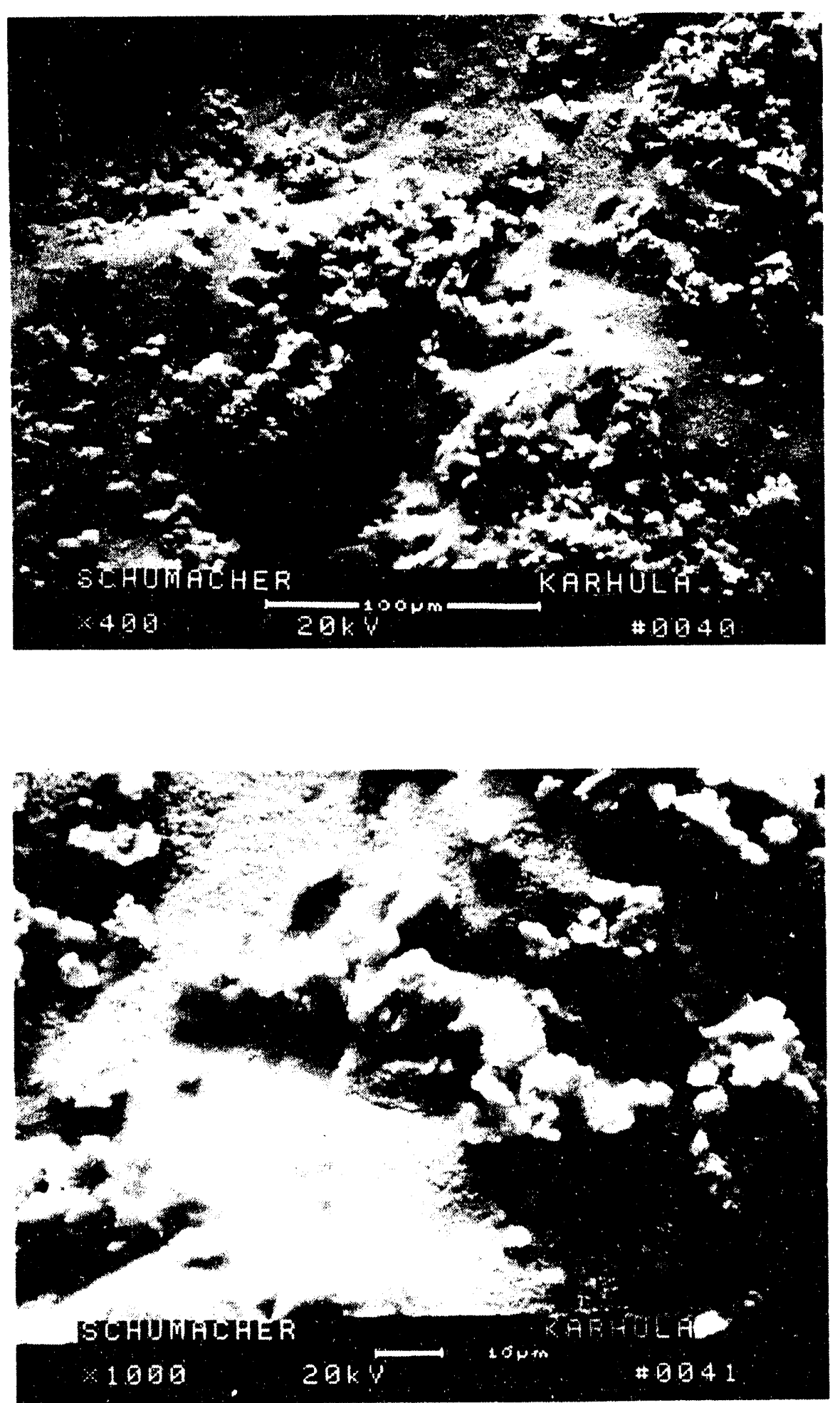

Figure 24b - Adherence Of Fines Along The Binder Conted Silicon Carbide Grains 


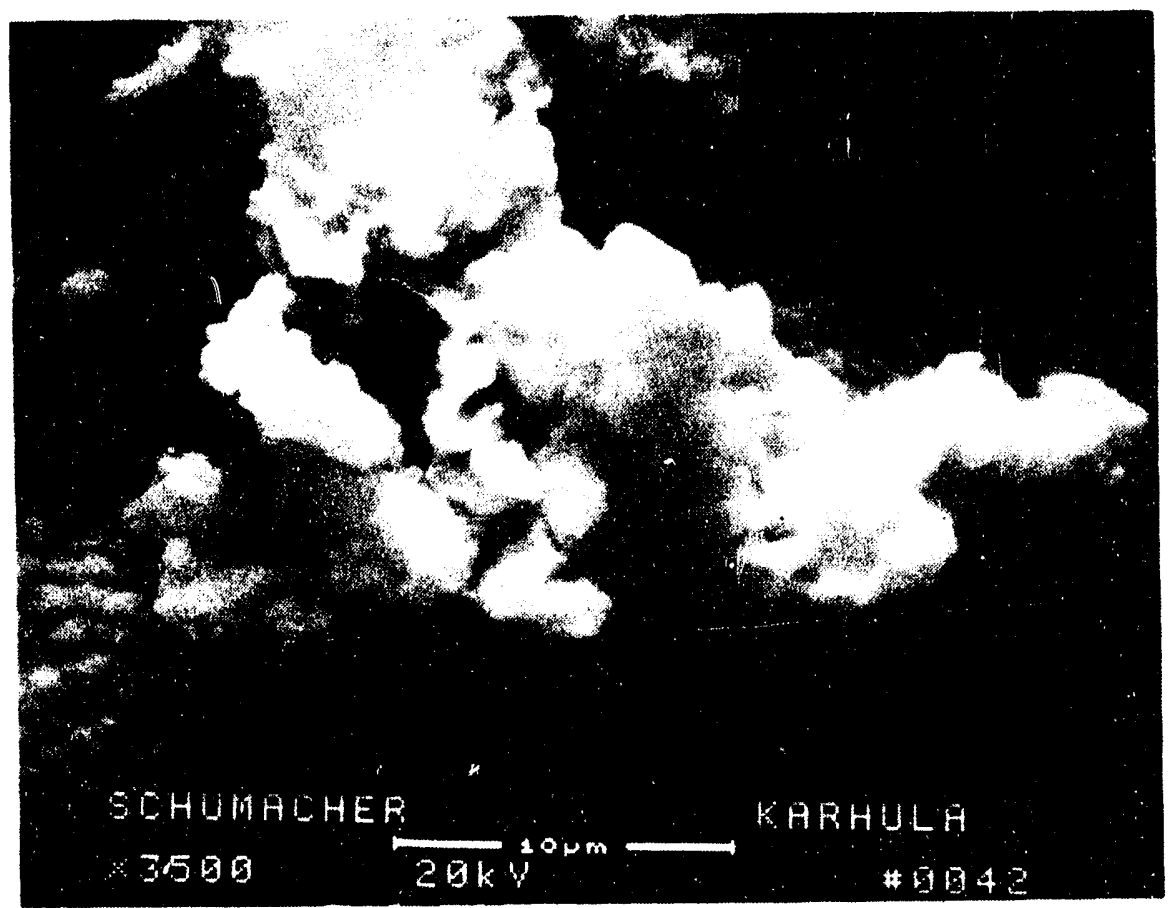

\section{Figure 24c - High Magnification Micrograph of The Fines Which Were Present Along The Silicon Carbide Grains Near The ID \\ Surface of The Clay Bonded Schumacher Dia Schumalith F40 Filter That Bxperience CFBC Operating Conditions}




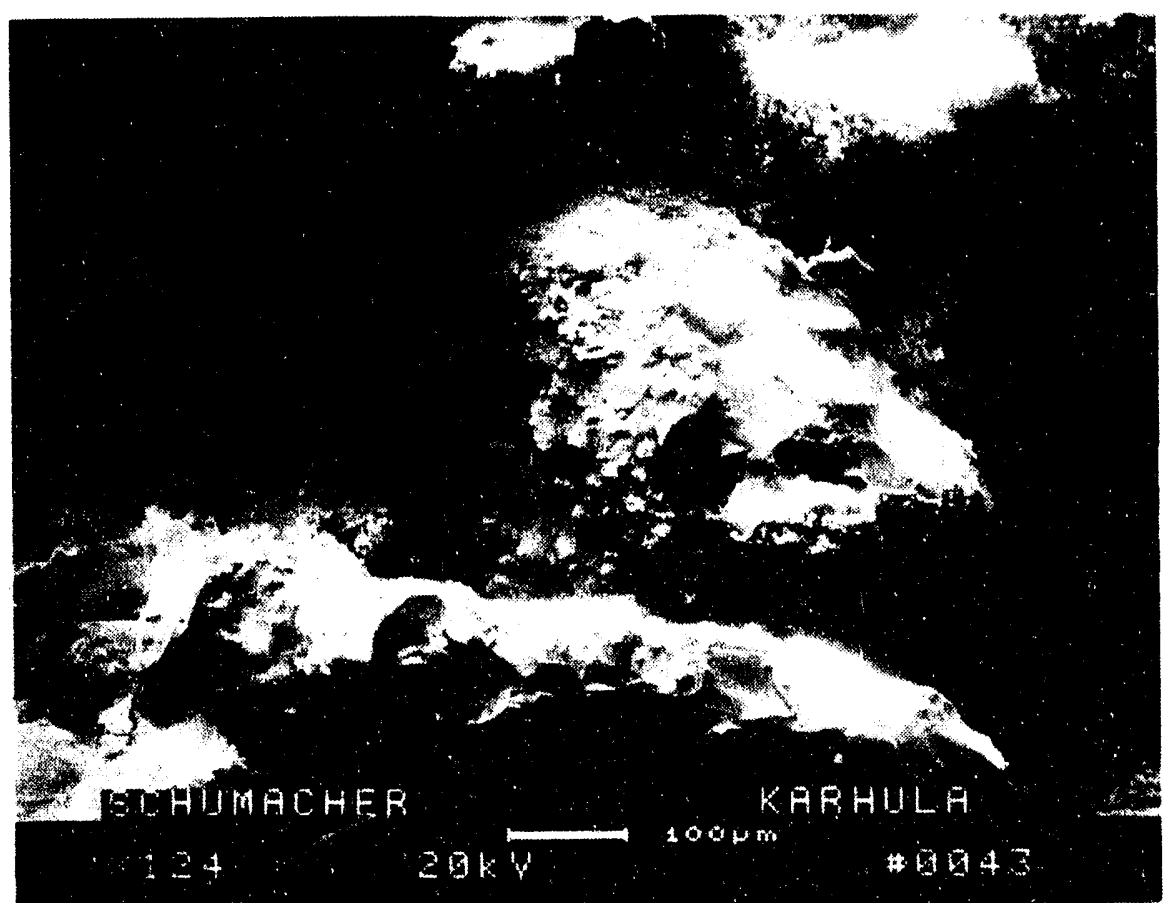

Figure 25a - Micrograph Illustrating The Adherence Of Fines Along
The Binder Coating Of The Silicon Carbide Grains In The
CFBC-Exposed Schumacher Dia Schumalith ID Surface 

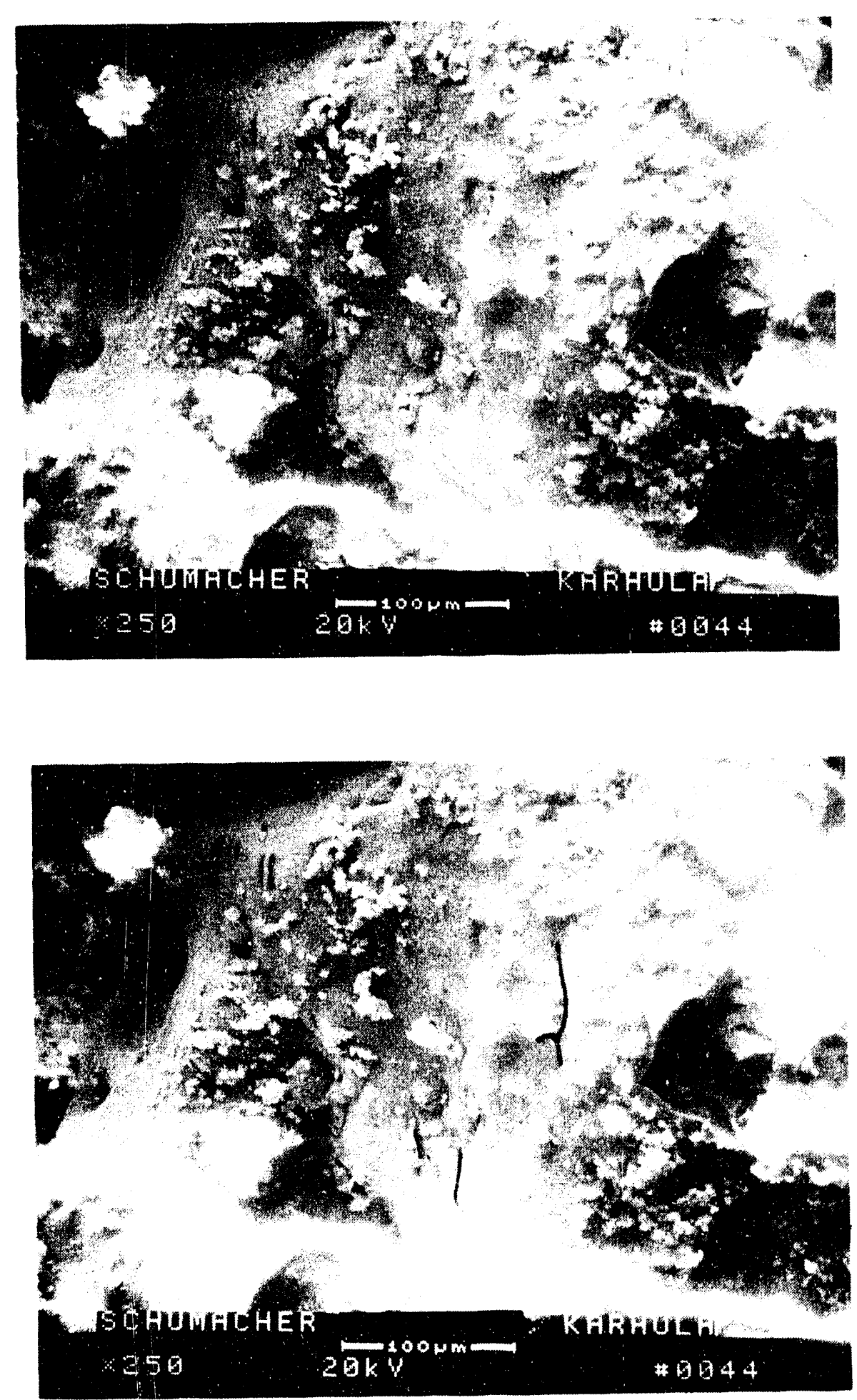

Figure 25b - Higher Magnification Nicrographs Indicating The Presence of Microcracks In The Binder Coating of The Clay Bonded Silicon Carbide Candle Filter ID Surface 

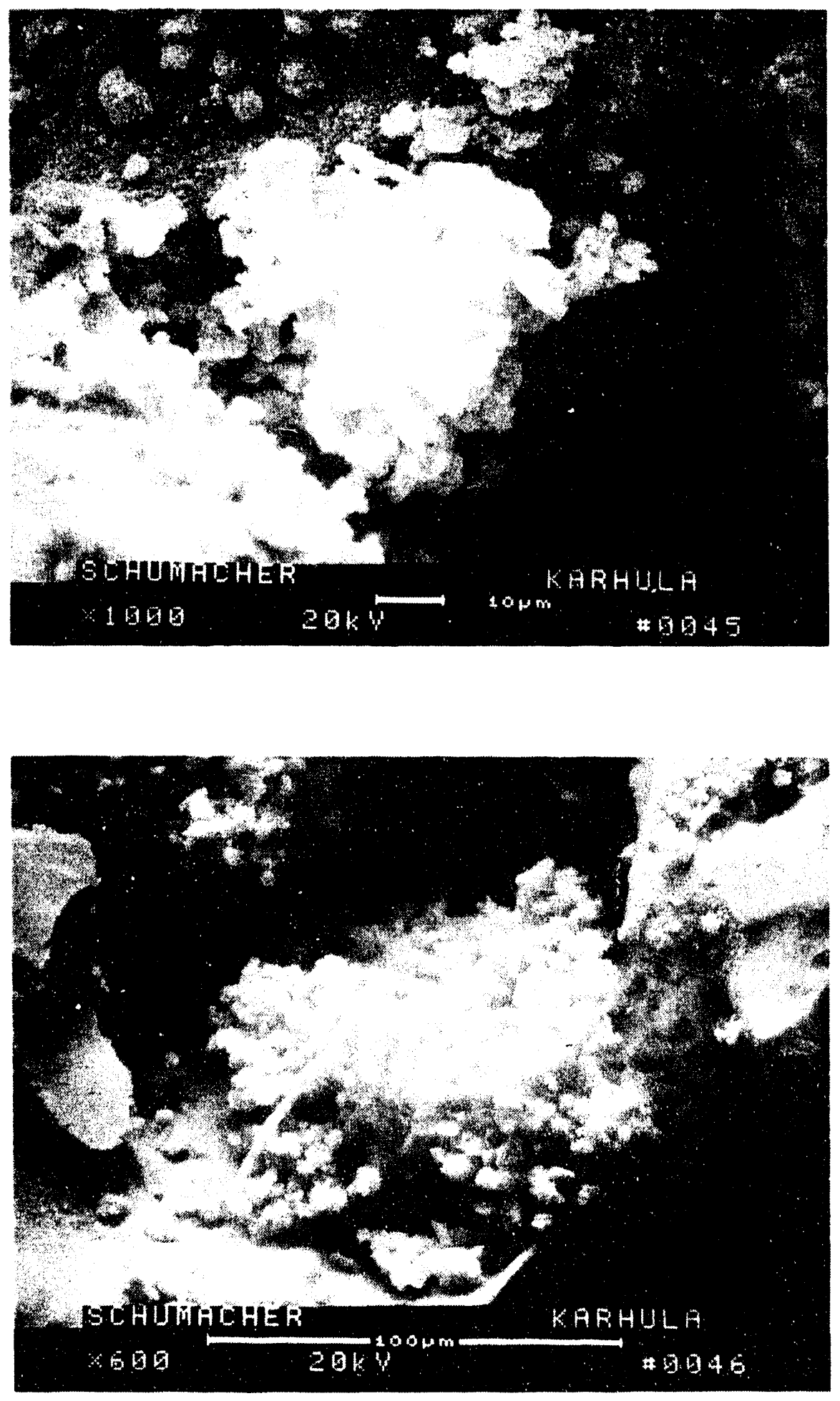

Figure 25c - High Magnification Micrographs Illustrating The Morphology of The Ash Fines Retained In The Clay Bonded Silicon Carbide Matrix After Exposure To The CFBC Gas Environment 
Figure 26 provides a series of micrographs at an alternate location which is approximately $1.5 \mathrm{~mm}$ from the candle filter ID surface. Again the mottled surface features of the binder phase are apparent, as well as the formation of microcracks through the binder coating (Photo 50, Figure 26b).

Fines are shown to fill the pore channels of the silicon carbide microstructure along the Schumacher Dis Schumalith F40 candle ID surface (Figure 27). Again the mat-like micron and submicron formations are evident along the binder surface. A higher magnification micrograph of the mat-1ike formations is shown in Figure 27c. The composition of the round nodules in the mat consists of $62.41 \% \mathrm{O}, 19.72 \% \mathrm{Si}, 12.42 \% \mathrm{Al}$, $1.71 \% \mathrm{Ca}, 1.33 \% \mathrm{Mg}, 0.90 \% \mathrm{Fe}, 0.70 \% \mathrm{Na}, 0.42 \% \mathrm{Ti}$, and $0.40 \% \mathrm{~K}$. Due to the presence of calcium and magnesium, and the higher aluminum content $(>7 \%)$ but lower silicon content $(\langle 35 \%)$, the mat-like formation is considered to contain submicron or micron ash particles as oppcsed to simply a phase transformation that results along the binder surface during operation in the CFBC gas environment at elevated process operating temperatures.

\section{Pall Vitropore 442T Candle Filters}

The morphology of the as-manufactured Pall Vitropore $442 \mathrm{~T}$ clay bonded silicon carbide candle filter matrix is shown in Figure 28. As the Schumacher Dia Schumalith F40 matrix, the Pall filters consist of silicon carbide grains that are bonded together via a high silicacontaining binder phase. EDAX characterization of the binder phase shown in Area 1, Photo 4, Figure 28b indicates the presence of $51.22 \% 0$, $42.43 \% \mathrm{Si}, 2.98 \% \mathrm{Na}, 2.83 \% \mathrm{Al}$, and $0.55 \% \mathrm{~K}$. Micron and submicron particulate-like features are seen to adhere to the binder phase of the as-manufactured Pall Vitropore 442T filters. These are artifacts of the manufacturing process, and are identified by EDAX to consist of $54.48 \%$ 

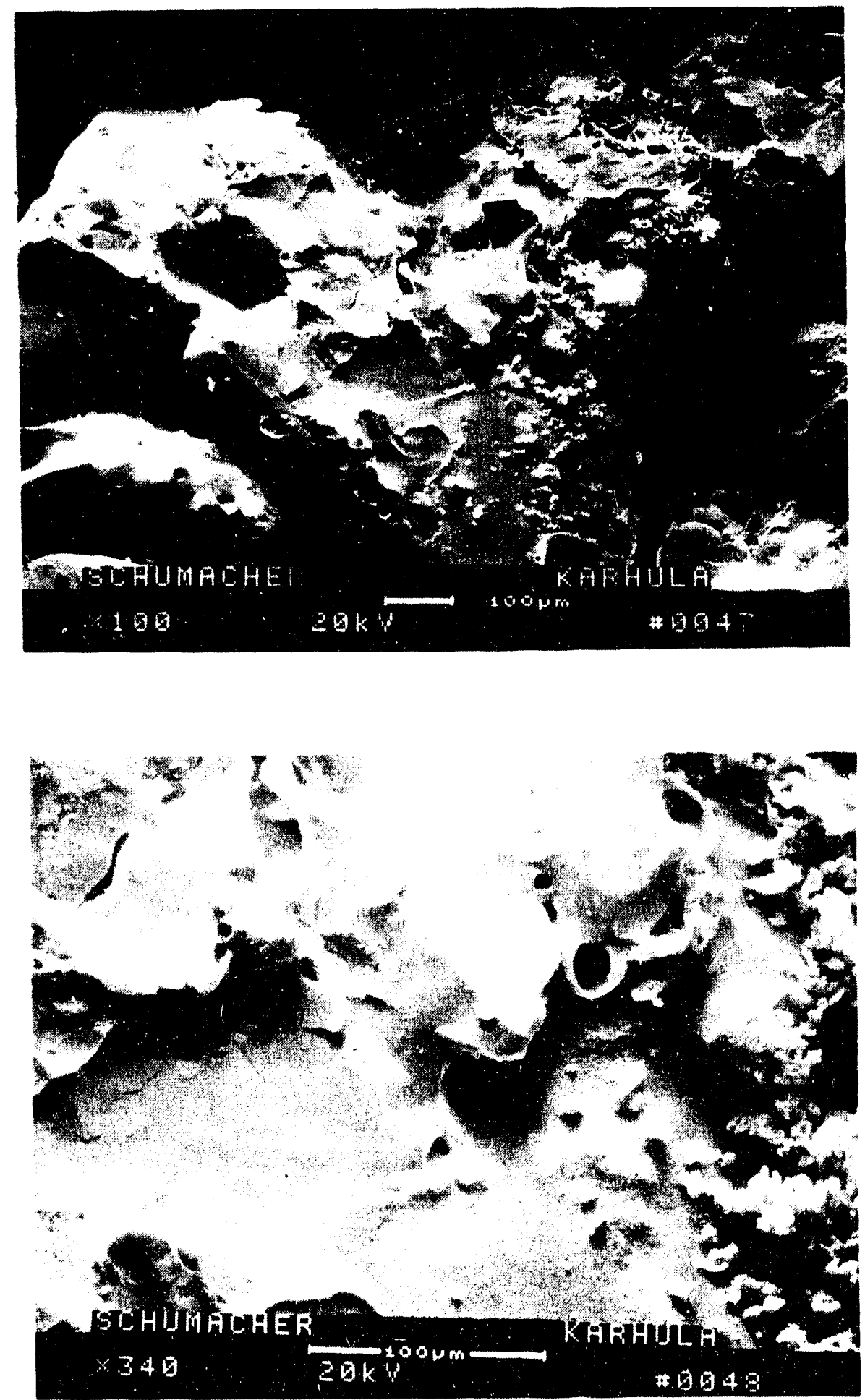

Figure 26a - Mottled Surface Features Of The Binder Phase Along The ID Surface Of The CFBC-Exposed Schumacher Dia Schumalith P40 Candle Filter Matrix 

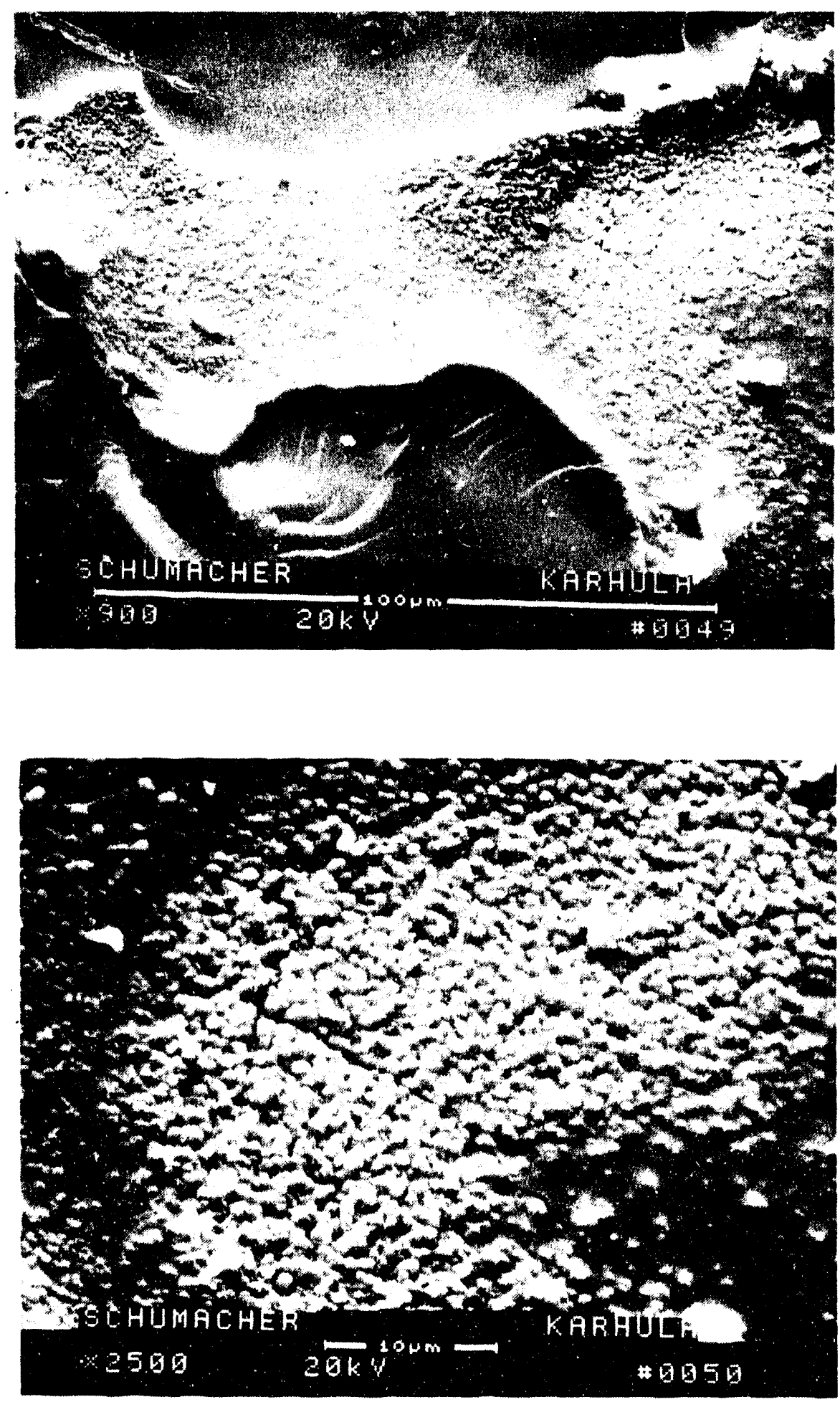

Figure 26b - Higher Magnification Micrographs Illustrating The Mat-Like Peatures And Vicrocrack Formations In The Binder Phase of The CPBC-Bxposed Schunacher Dia Schumalith F40 Candle Pilter Matrix 


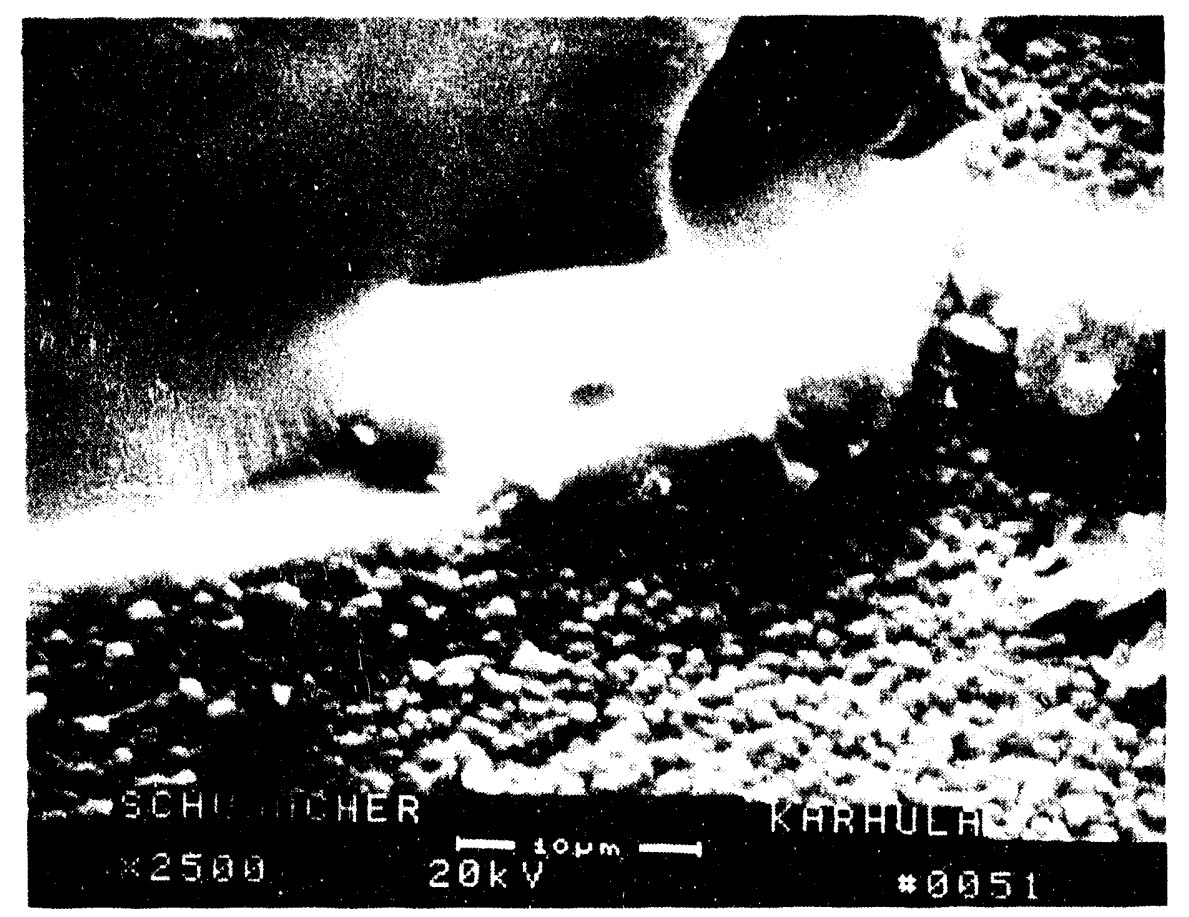

\footnotetext{
Figure 26c - Yat-Like Surface Features of The CFBC-Exposed Schumacher Dia Schumalith F40 Binder
} 

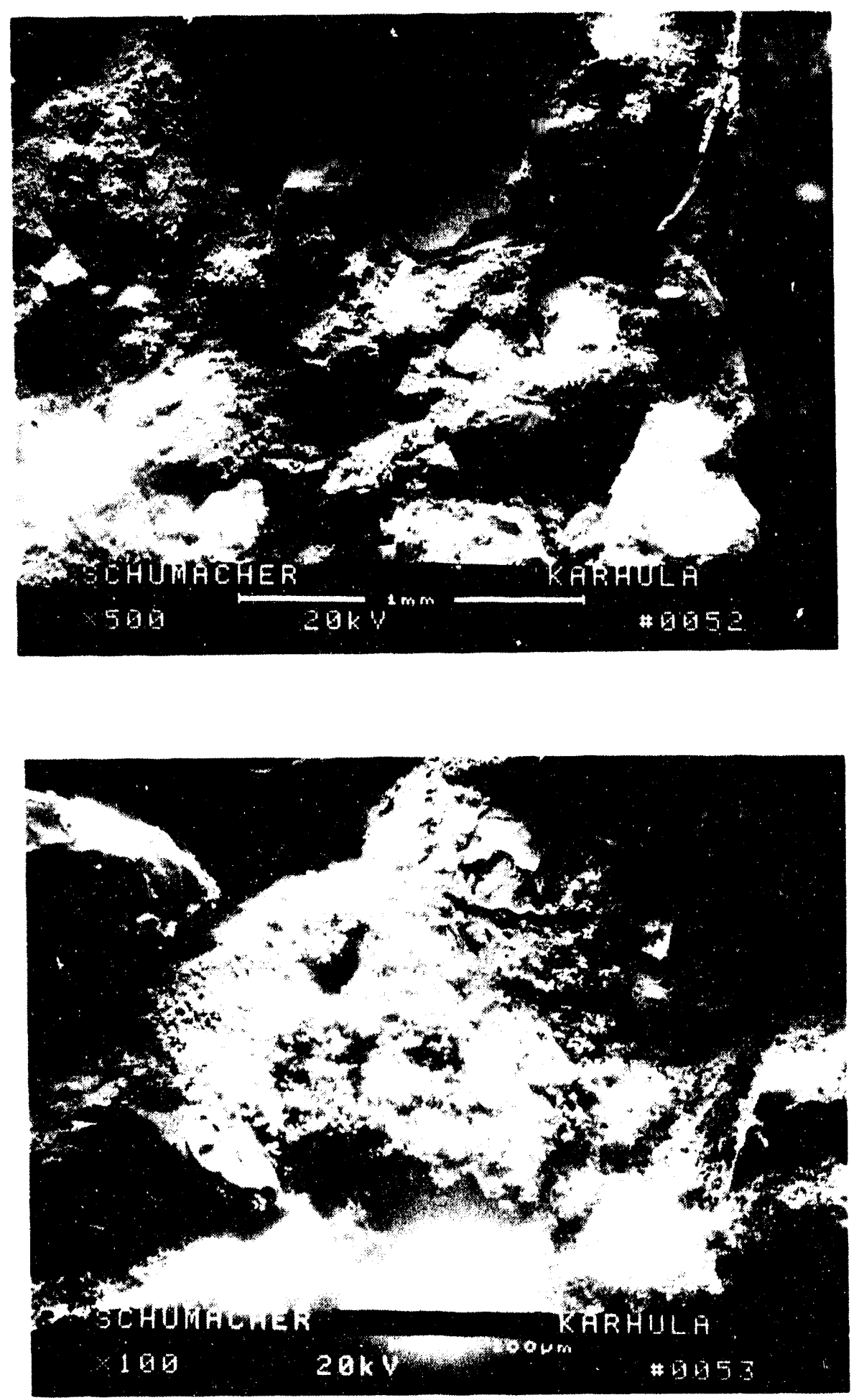

Figure 27a - Adherence Of Fines Along The Binder Coated Silicon Carbide Grains In The CFBC-Exposed Schumacher Dia Schumalith F40 Filter Yatrix 

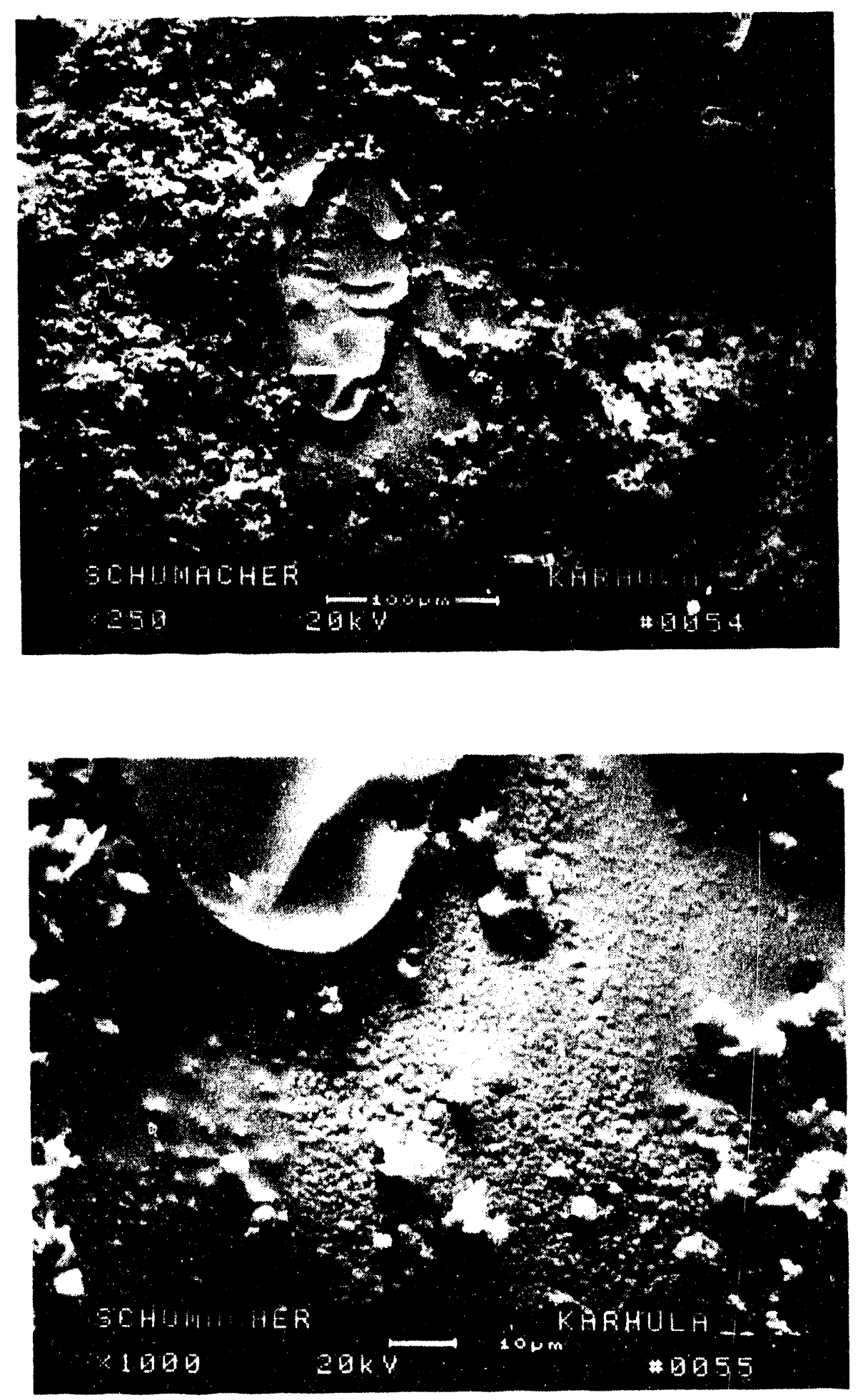

Figure 27b - Higher Magnification Vicrograph of The Fine Particulates
Attached To The Binder Coated Silicon Carbide Grains 


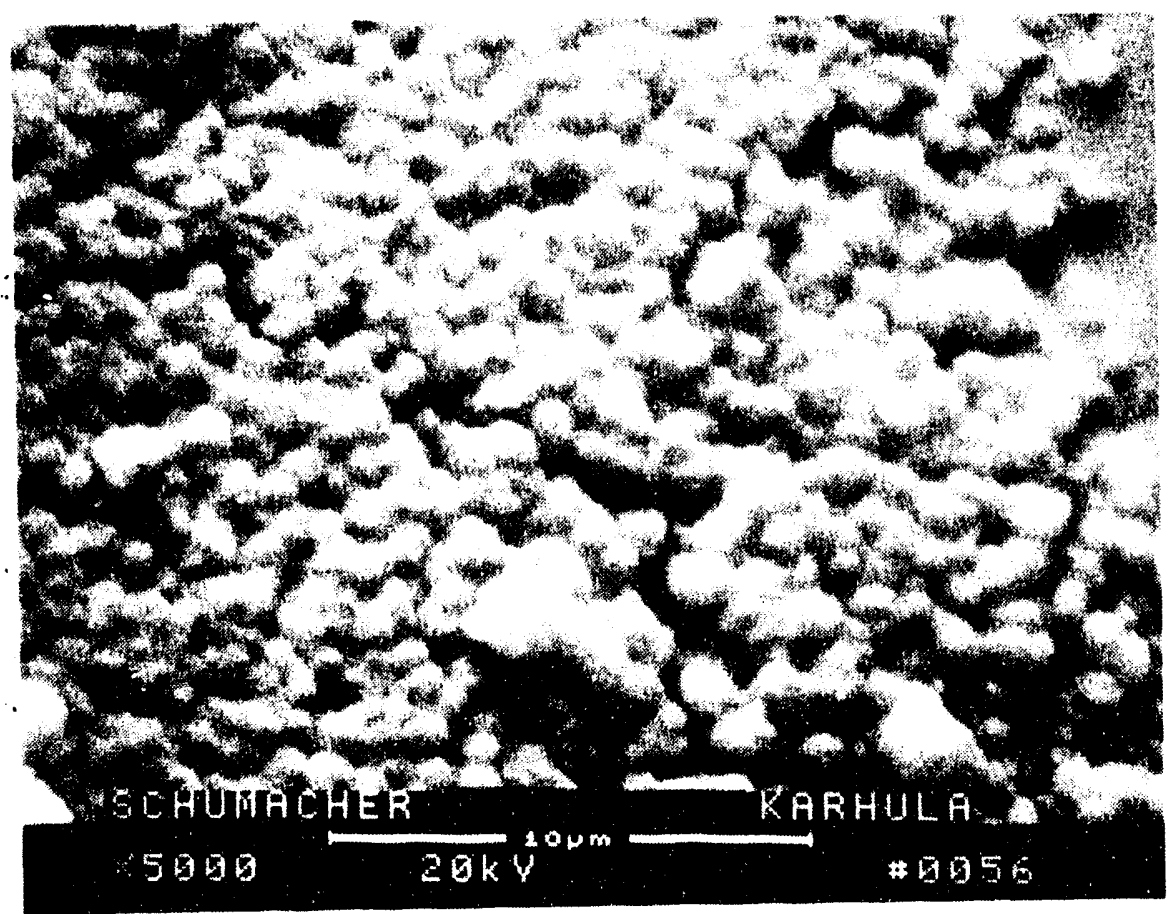

Figure 27c - High Magnification Micrograph Illustrating The Morphology of The Binder Coated Silicon Carbide Grains In The CFBCExposed Schumacher Dia Schumalith F40 Matrix 

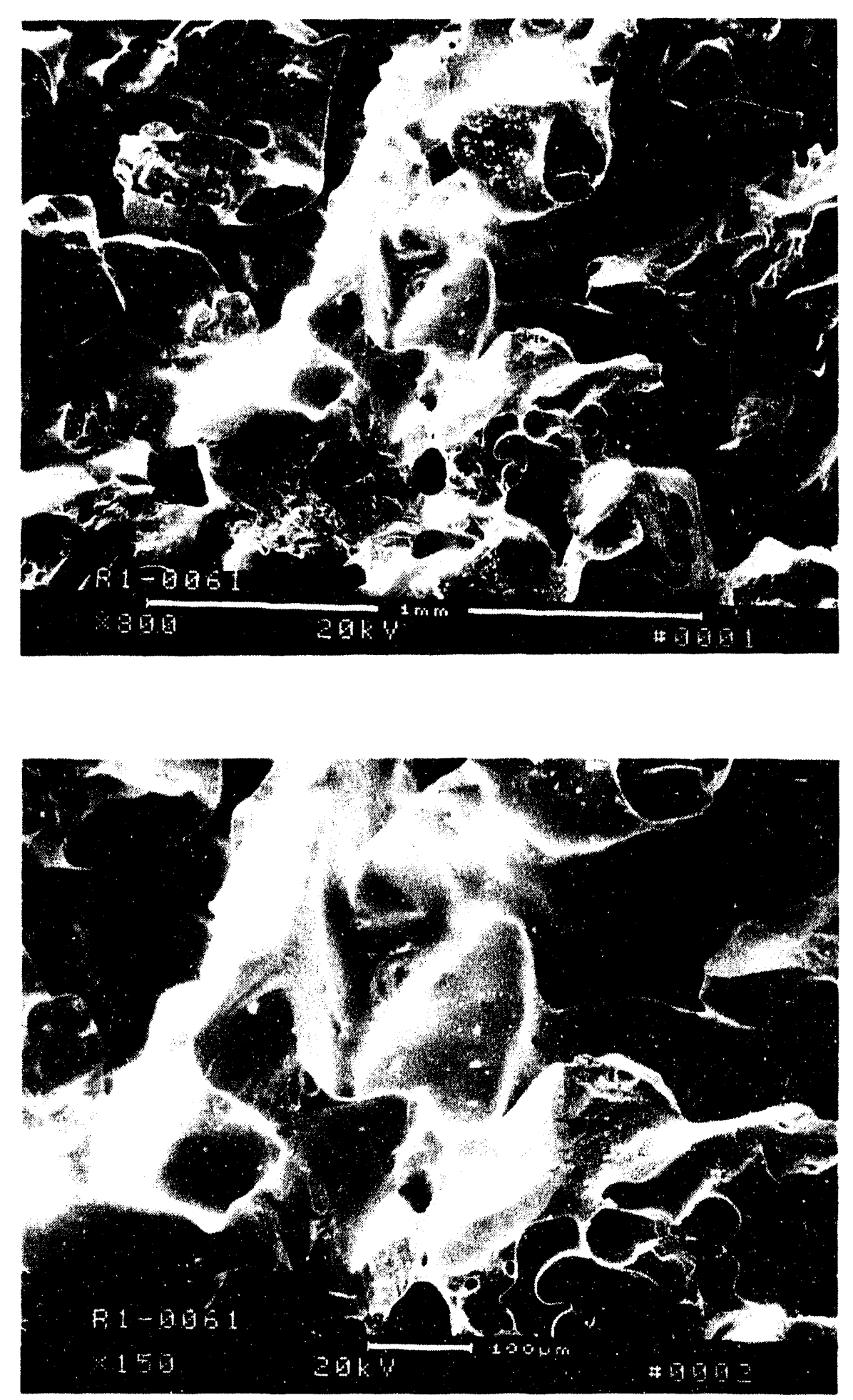

Figure 28a - Micrographs Illustrating The Norphology Of The AsYanufactured Pall Vitropore 442T Pilter Matrix 

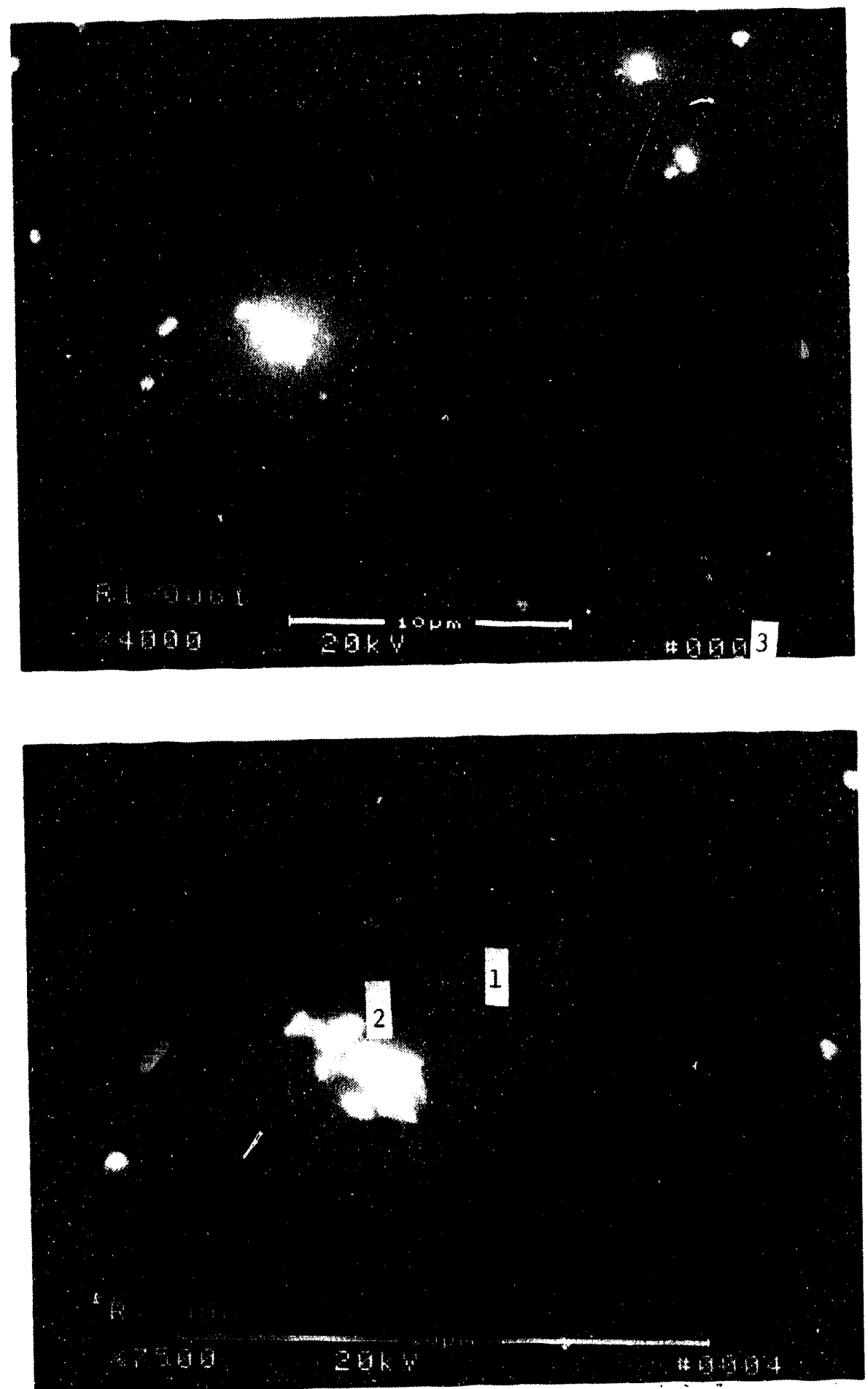

FIgure 28b - High Magnification Yicrographs Illustrating The Smooth Binder Phase Which Is Present In The As-Manufactured Pall Vitropore 442T Candle Filters 

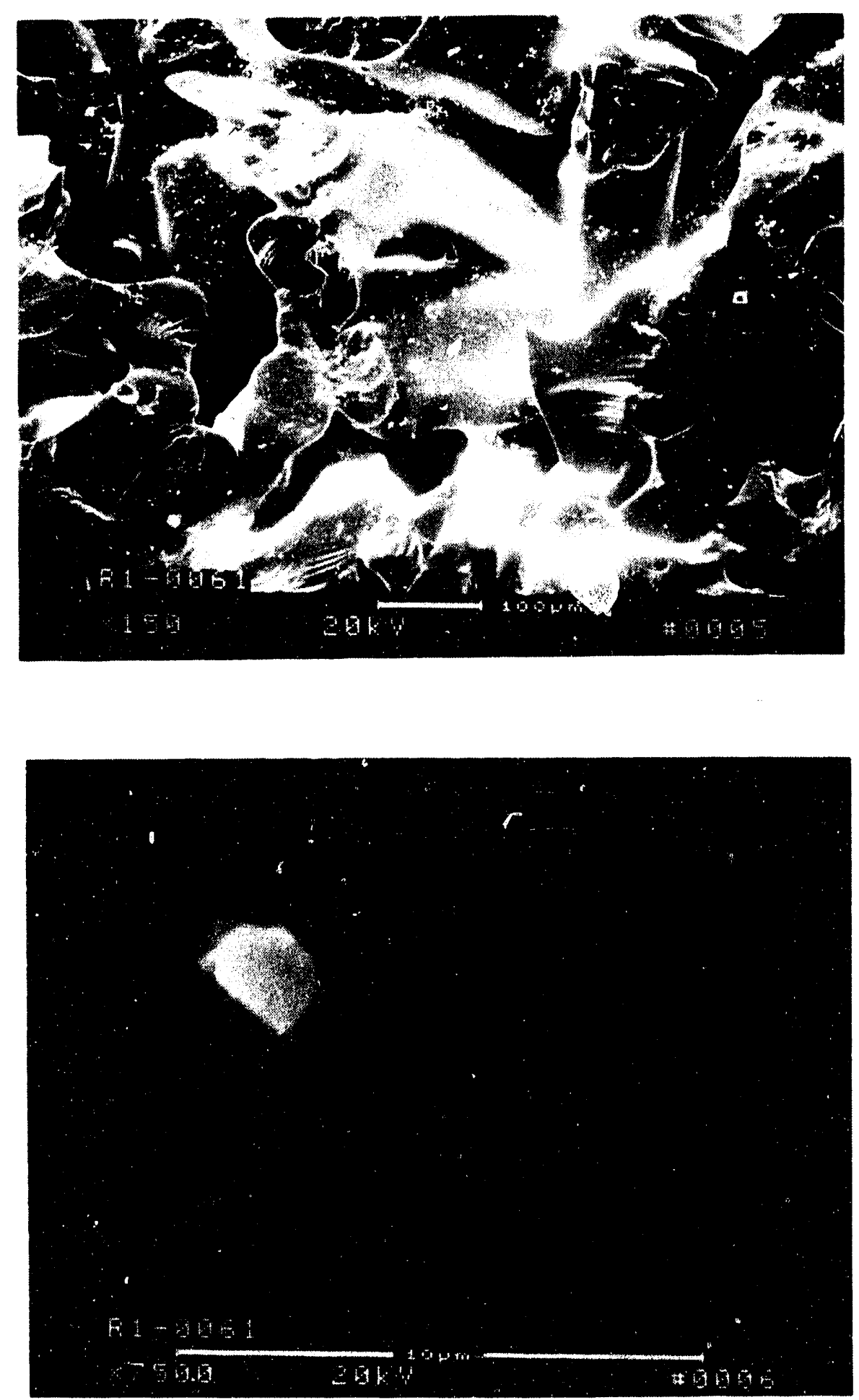

Figure 28c - Morphology of The Pall Vitropore 442T Candle Filter Matrix At An Alternate Location 
$0,36.95 \% \mathrm{Si}, 4.86 \% \wedge 1,3.11 \% \mathrm{Na}$, and $0.59 \% \mathrm{~K}$ (Area 2, Photo 4, Figure 28b). The fine particulate-like features are infrequently detected along the smooth binder phase in the clay bonded silicon carbide Pall Vitropore $442 T$ candle filter matrix.

Based on EDAX analysis of a carbon coated sample of the Pall filter which was exposed to the CFBC gas environment, the ash fines which adhere to the candle filter $O D$ surface were identified to contain $65.21 \% \mathrm{O}, 27.64 \% \mathrm{Si}, 4.48 \% \mathrm{Al}, 1.40 \% \mathrm{Na}, 0.37 \% \mathrm{Fe}, 0.36 \% \mathrm{Ca}, 0.35 \% \mathrm{~K}$, $0.23 \% \mathrm{~s}$, and $0.13 \% \mathrm{Ti}$. As a result of the low concentration of sulfur in the fines, an additional sample of the CFBC-exposed Pall filter matrix was removed and gold coated in order to generate more distinct, high resolution micrographs. Figure 29 illustrates the morphology of the OD membrane and supporting silicon carbide grains along the crosssectioned Pall Vitropore 442T filter which was exposed for 227 hours in the CFBC gas environment.

The thickness of the fine grained OD membrane along the Pall Vitropore $442 \mathrm{~T}$ filter as shown in Photo 1 , Figure 29a is approximately 100-300 $\mu \mathrm{m}$, depending on the contour of the underlying coarse silicon carbide grain support layer. Photos 2 through 5, Figure 29 provide a series of high magnification micrographs which illustrate the morphology of the OD membrane-first grain support layer in the Pall CFBC-exposed matrix. Note the rather mottled surface features of the binder coated silicon carbide grains.

Figure 30 illustrates the morphology of the membrane-first grain layer at an alternate location along the Pail Vitropore 442T matrix. Note the relatively large amorphous area of the material in the micrographs shown in Figure 30. BDAX analysis of Area 1 , Photo 7 , Figure 30 indicates the presence of $55.23 \% \mathrm{Si}, 36.55 \% \mathrm{O}, 5.29 \% \mathrm{Al}$, and 2.94\% K (high carbon content also indicated). Based on the EDAX analyses, the amorphous areas are considered to be a combination of both the silicon carbide grain and binder phase. 

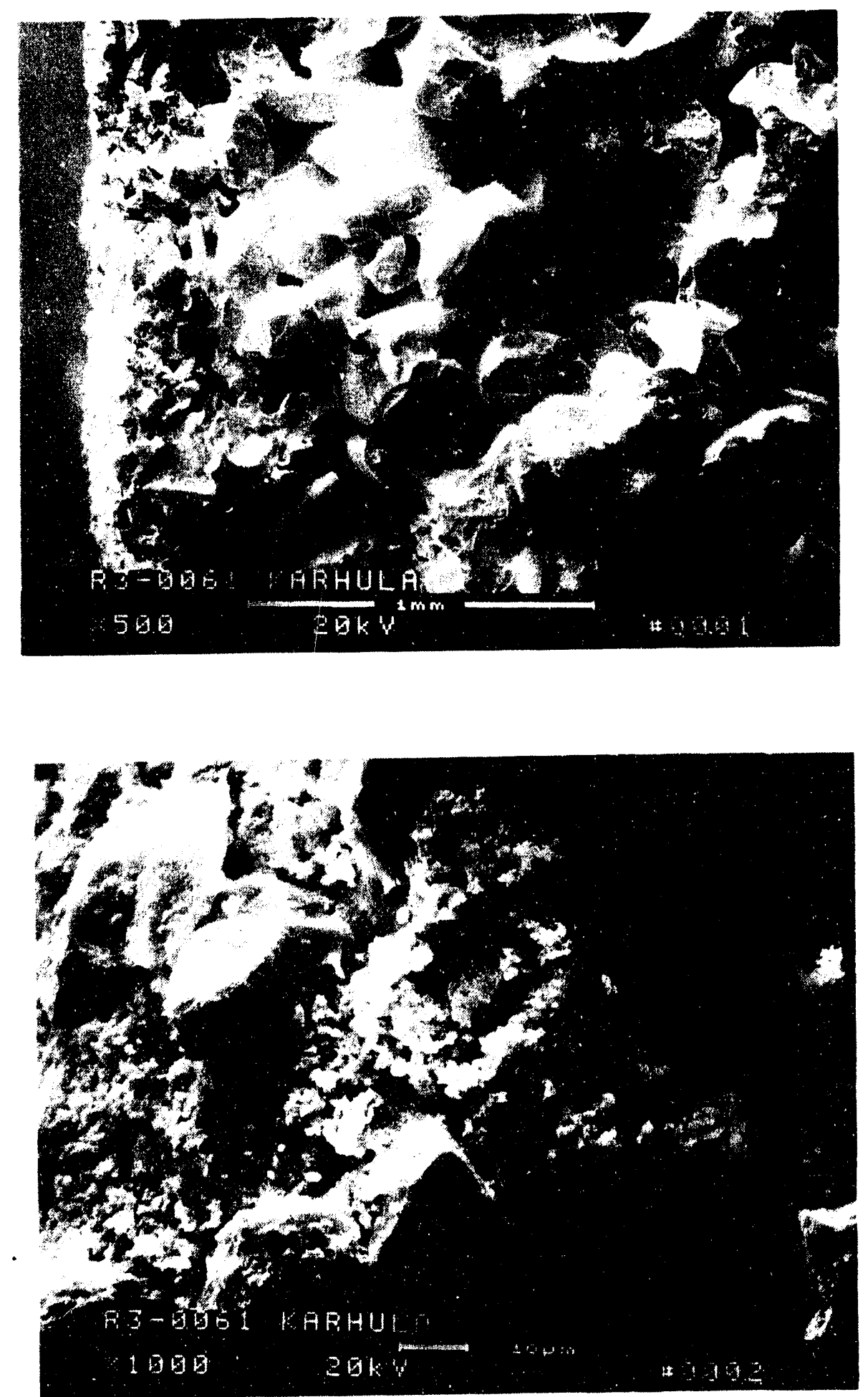

Figure 29a - Morphology of The GBBC-Exposed Pall Vitropore 442T Candle Filter OD Membrane And Pirst Grain Layers 

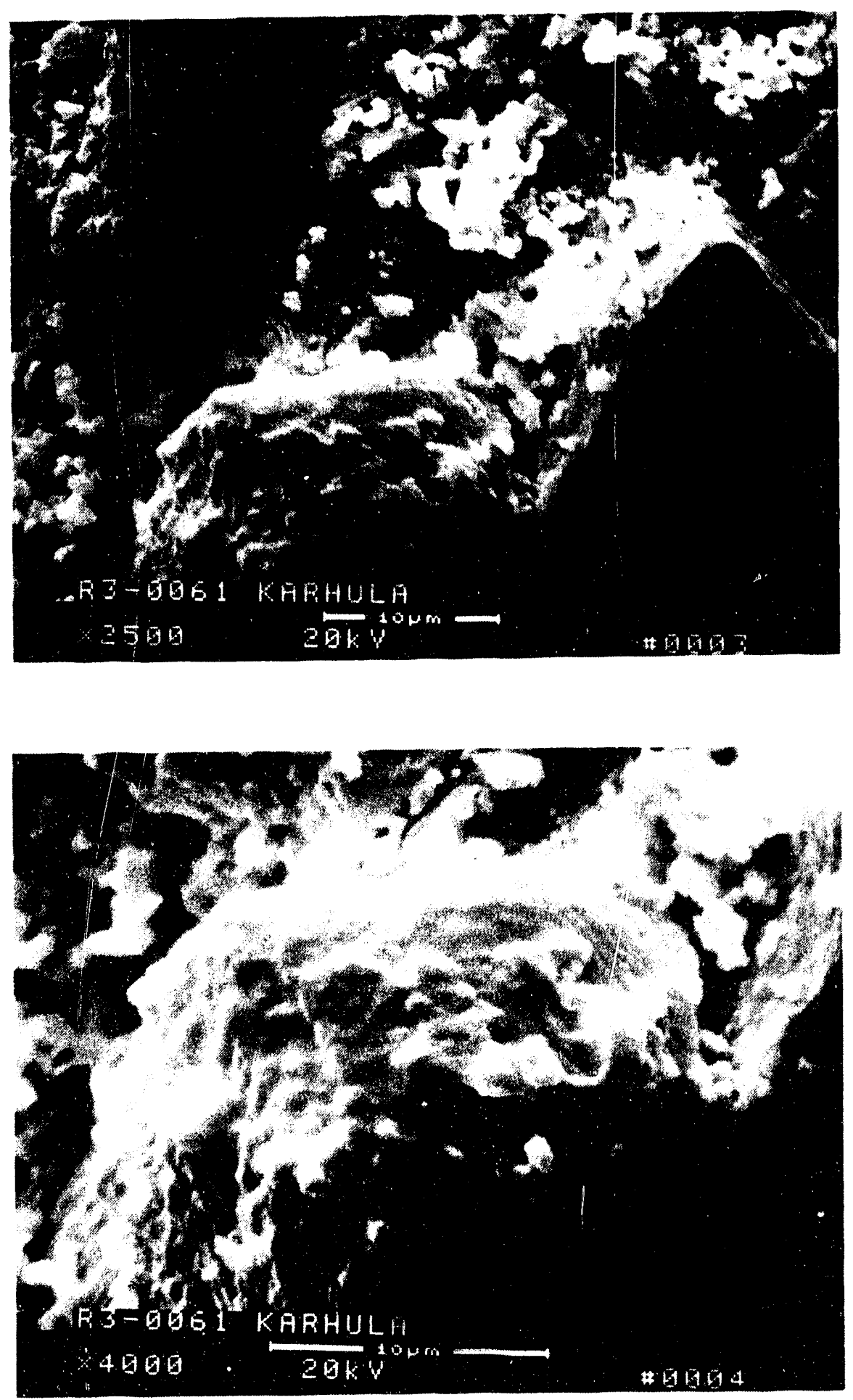

Figure 29b - Morphology of The Silicon Carbide Grains Near The OD Membrane Surface of The CFBC-Exposed Pall Vitropore 442T Candle Filter. Yottling of The Binder Phase Is Apparent, As Well As The Adherence of that Appears To Be Particulate Ash Fines. 


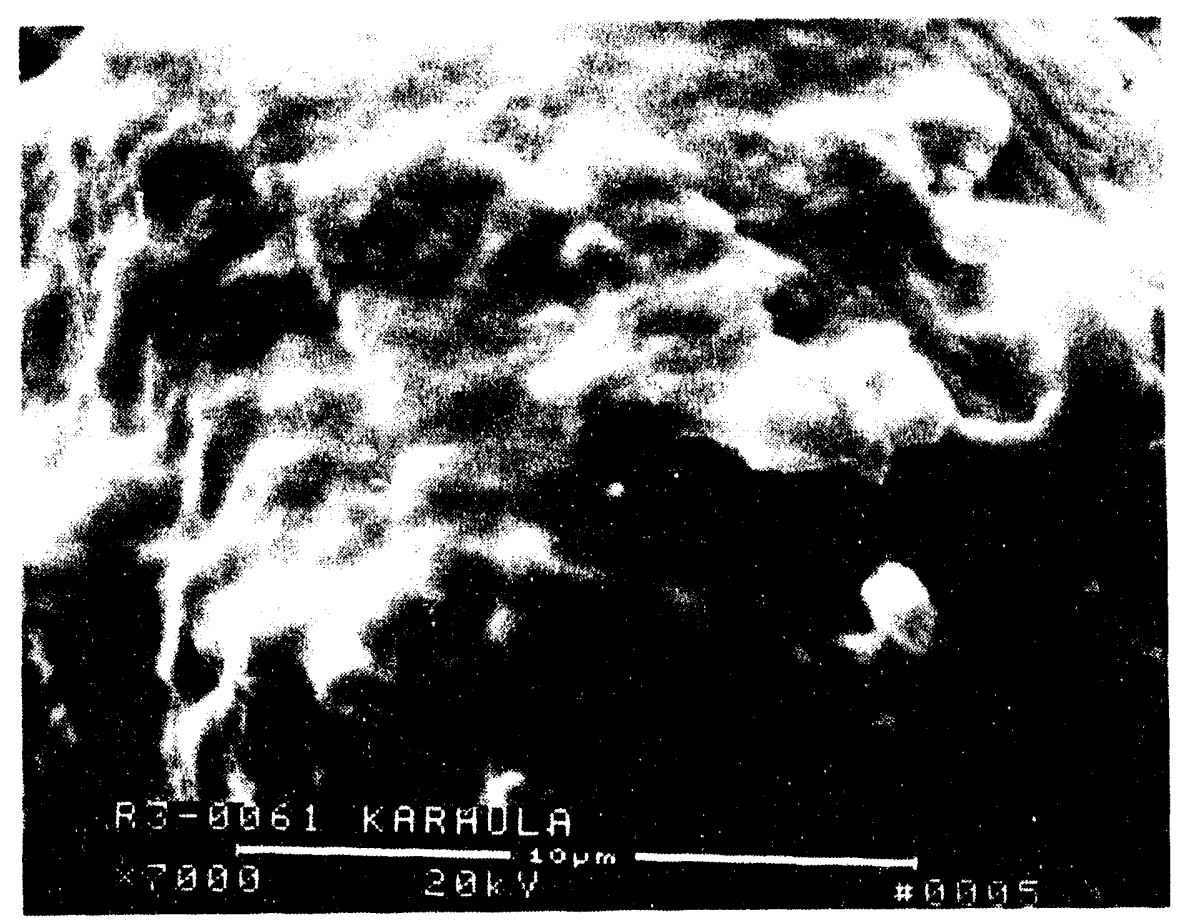

Figure 29c - Higher Magnification Micrograph Illustrating The Mottled Surface Features of The Binder Phase Which Coats The Silicon Carbide Grains In The CFBC-Exposed Pall Vitropore 442T Candle Filters 

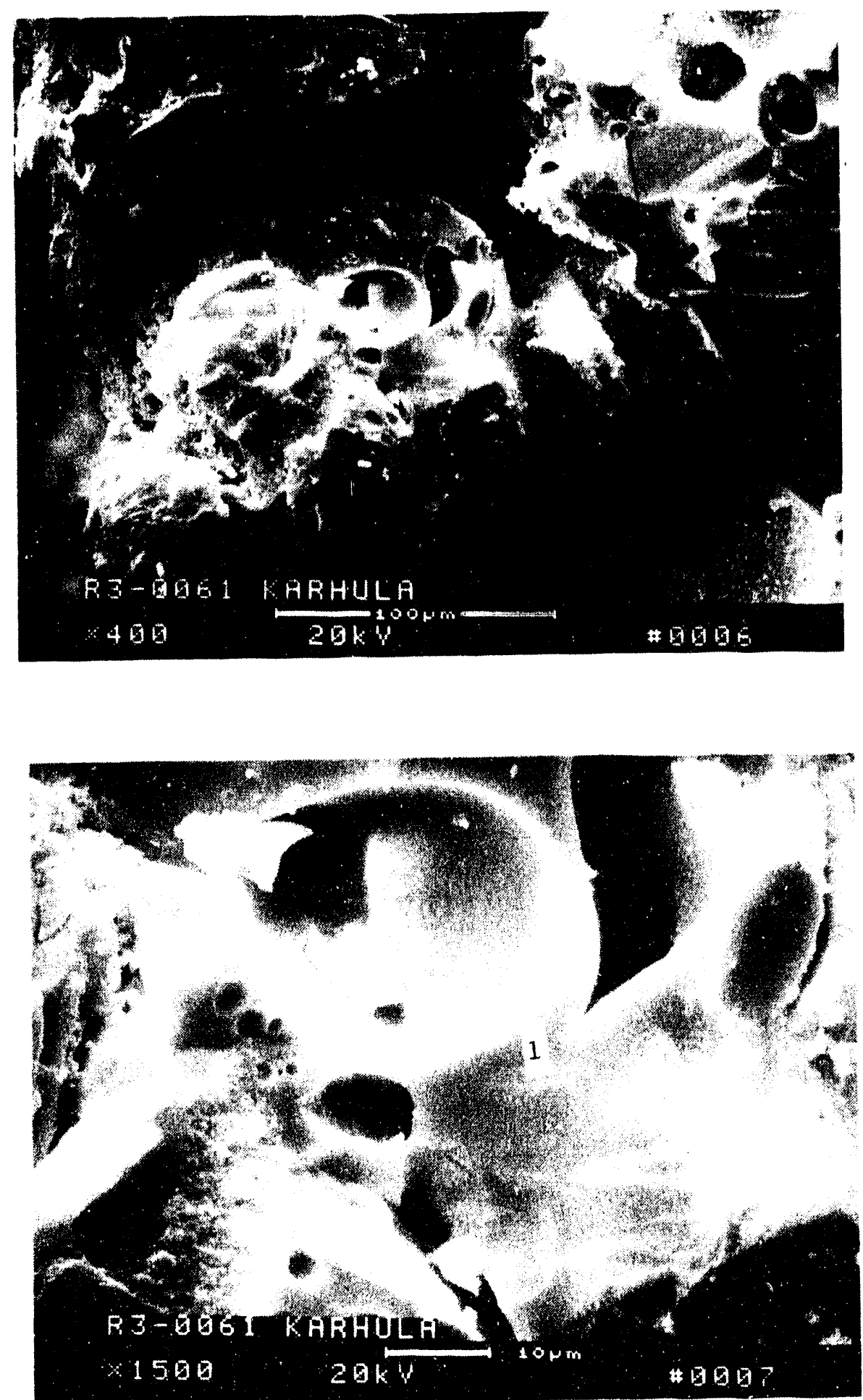

Pigure 30 - Nicrographs Illustrating The Norphology of The Pall Vitropore 442T Candle Filter At An Alternate Location Near The OD Membrane 
Figure 31 begins to explore the morphology and phase changes that result along the binder coating of the first grain layer beneath the OD membrane of the CFBC-exposed Pall Vitropore 442T matrix. The outer surface of the binder contains numerous 1-2 $\mu \mathrm{m}$ raised and rounded features. Cracks are also evident in the binder surface. A higher magnification micrograph of the area shown in Area 1 , Photo 3 , Figure 31b is shown in Photo 4, Figure 31b. The "white" spherical micron feature consists of $59.01 \% 0,33.13 \% \mathrm{Si}, 6.10 \% \mathrm{Al}, 1.38 \% \mathrm{Fe}$, and $0.38 \% \mathrm{~K}$. Due to the somewhat higher oxygen content, yet lower silicon content, Area 1 may be an ash particle. The grayish raised, approximately $1 \mu \mathrm{m}$ feature in Area 2 of Photo 4, Figure 31b consists of $50.40 \% 0,40.46 \% \mathrm{Si}, 6.48 \% \mathrm{Al}, 1.51 \% \mathrm{Fe}$, and $1.15 \% \mathrm{~K}$. The underlying binder substrate (Area 3 ) consists of $47.56 \% \mathrm{Si}, 39.76 \% \mathrm{0}, 7.75 \% \mathrm{Al}$, $2.56 \% \mathrm{Fe}, 1.46 \% \mathrm{~K}$, and $0.92 \%$ of a rare earth additive that is used during the manufacture of the $\mathrm{Pall}$ Vitropore $442 \mathrm{~T}$ filters to provide oxidative stability and/or corrosion resistance to the clay bonded silicon carbide filter matrix.

Figure 32 illustrates the mottled surface features of the binder phase along an alternate grain near the OD membrane. At high magnification (Photo 7, Figure 32b) it is evident that the binder phase has separated from the underlying silicon carbide grain. EDAX characterization of Area 1, Photo 7, Figure 32b indicates that the binder contains $66.47 \% 0,28.80 \% \mathrm{Si}, 3.70 \% \wedge 1,0.60 \% \mathrm{~K}, 0.25 \%$ rare earth, and $0.20 \% \mathrm{Fe}$. Area 2 (Photo 7, Figure 32b) along the binder/gain interface appears to contain cracks, and as identified by EDAX consists of $55.12 \% 0,42.02 \% \mathrm{Si}, 1.95 \% \mathrm{Al}, 0.55 \% \mathrm{~K}, 0.25 \% \mathrm{Fe}$, and $0.11 \%$ rare earth which again implies the presence of the binder layer. The silicon carbide grain is located in Area 3, Photo 7, Figure 32b.

Figure 33 provides an additional series of micrographs detailing the morphology of the binder coated silicon carbide grains at an alternate location near the OD membrane surface of the CFBC-exposed Pall Vitropore $442 T$ filter. Again note the extensive mottling of the 

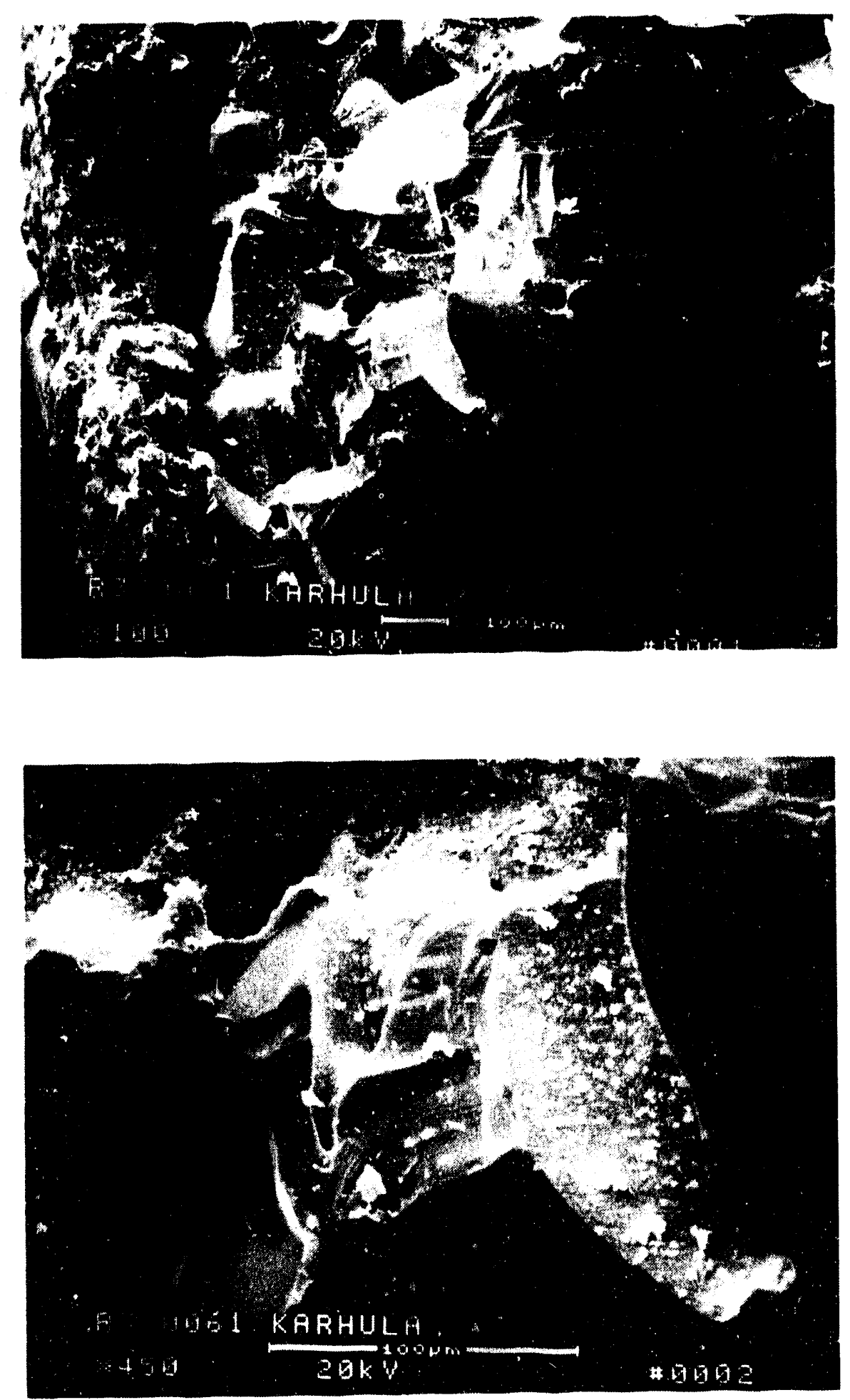

Figure 31a - Micrographs Illustrating The Korphology of The Binder Phase Along The Pirst Grain Layer In The CFBC-Exposed Pall Vitropore 442T Pilter Matrix 

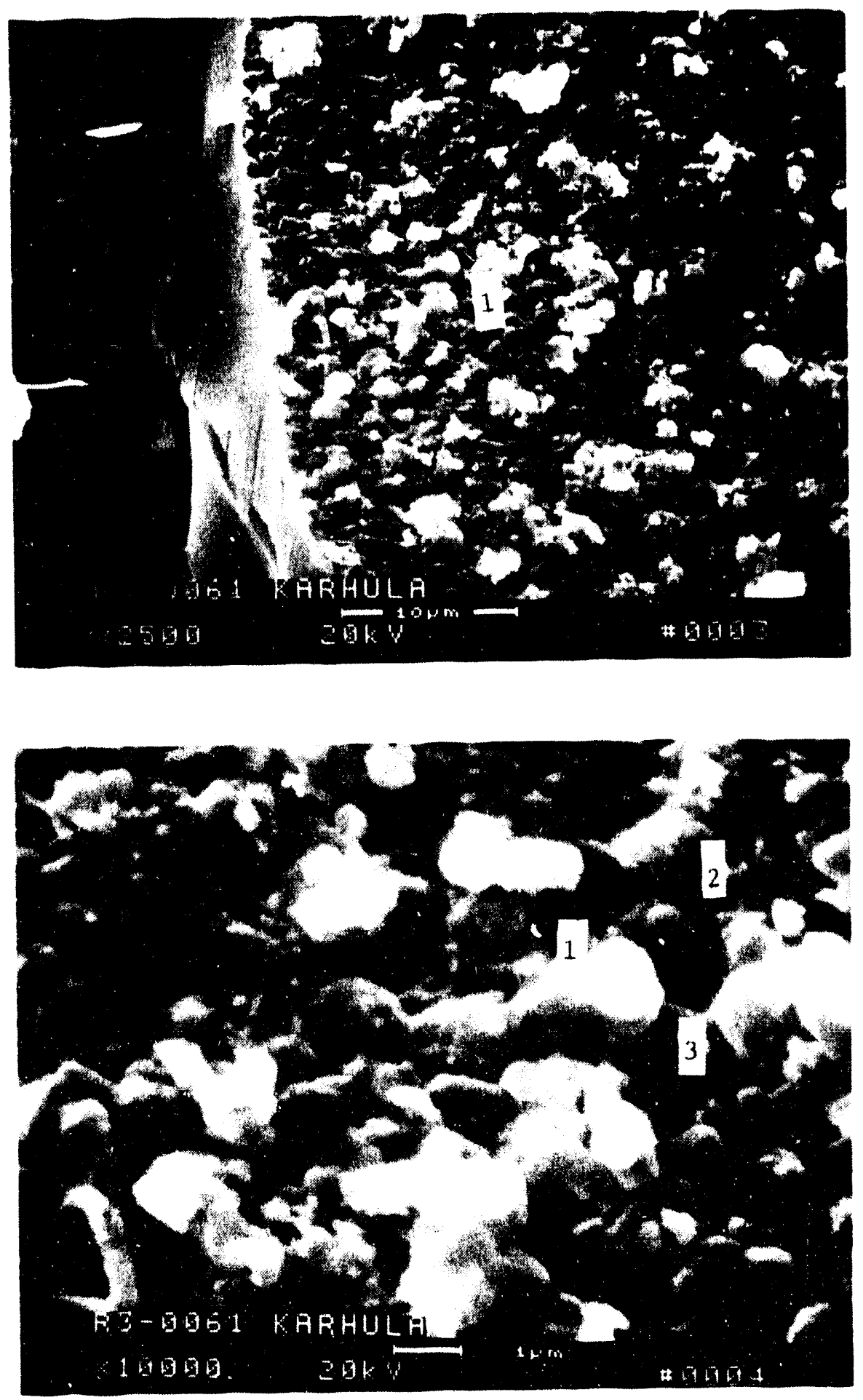

Pigure 31b - Higher Magnification Micrographs Illustrating The Mottled Surface Features of The Binder Coating 

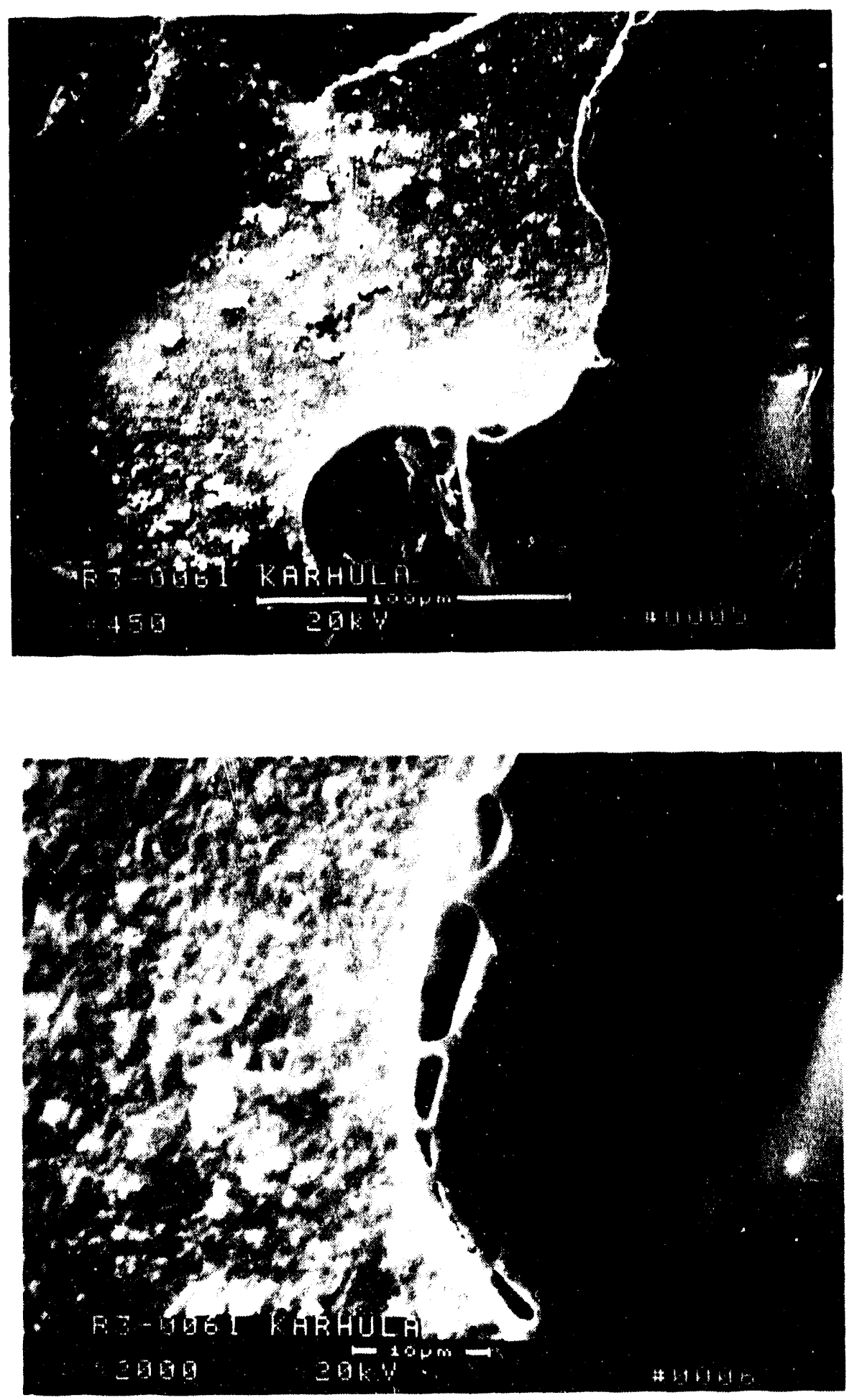

Figure 32a - Micrographs Illustrating The Morphology Of The CFBC-Exposed Pall Vitropore 442T Matrix At An Alternate Grain Near The OD Vembrane of The Cross-Sectioned Filter 


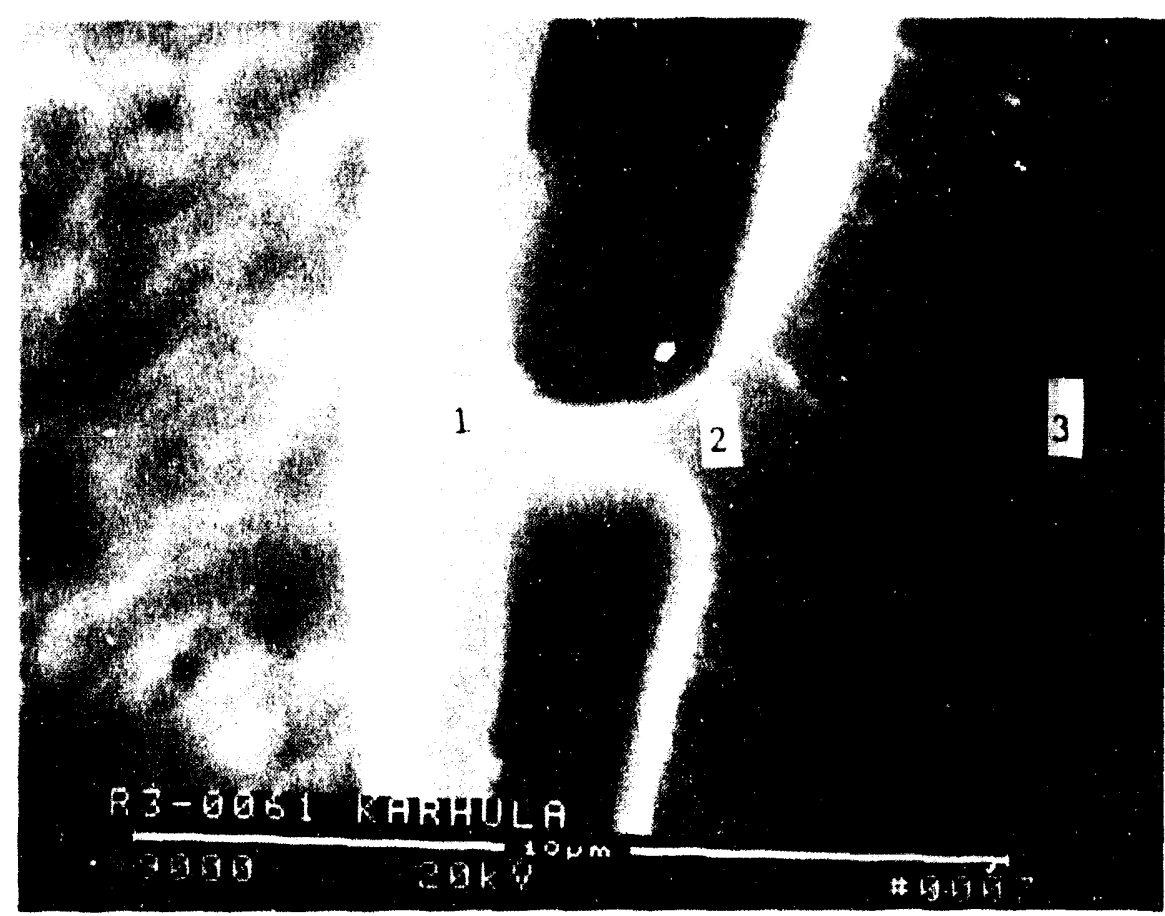

Figure 32b - Higher Magnification Micrograph Illustrating The Raised And Separated Peatures of The Binder Coating Along A Silicon Carbide Grain 

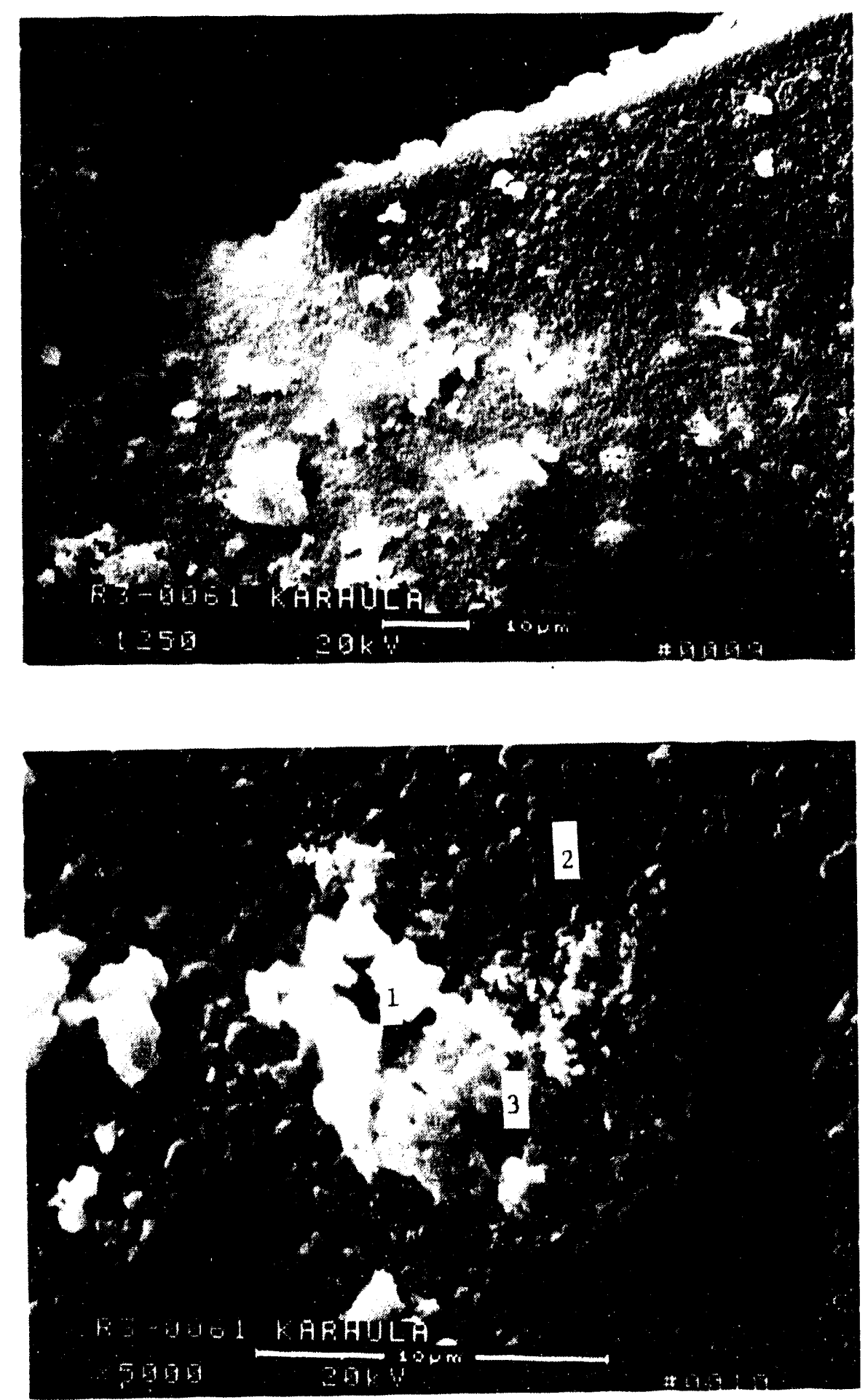

Figure 33a - Micrographs Illustrating The Extensive Mottling of The Binder Surface Near The OD Membrane of The CFBC-Exposed Pall Vitropore 442T Filter 

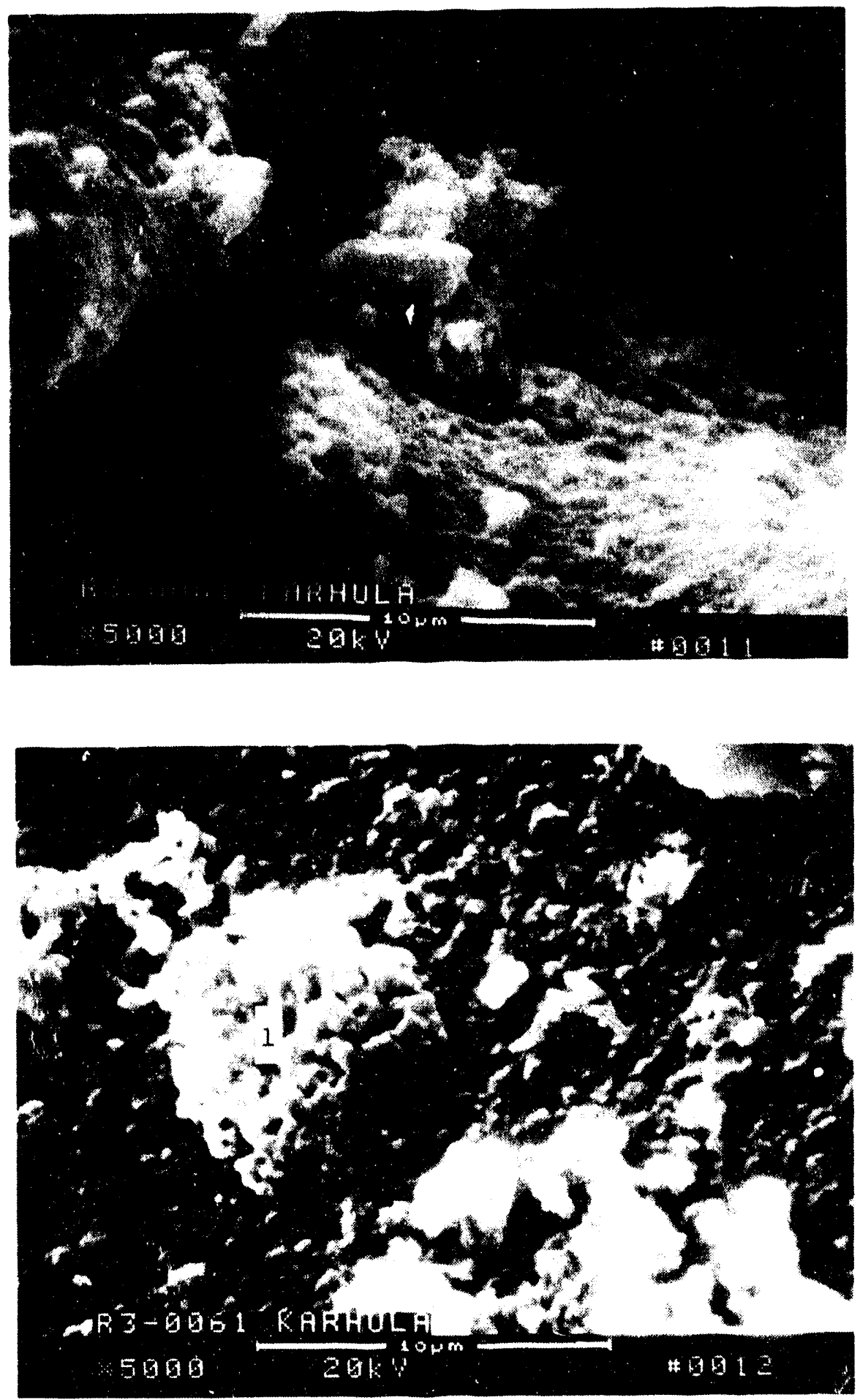

Figure 33b - Additional Micrographs Illustrating The Mottled Surface Features of The Binder Phase Which Coats The Silicon Carbide Grains Near The OD Meabrane of The CFBC-Exposed Pall Vitropore 442T Filter 


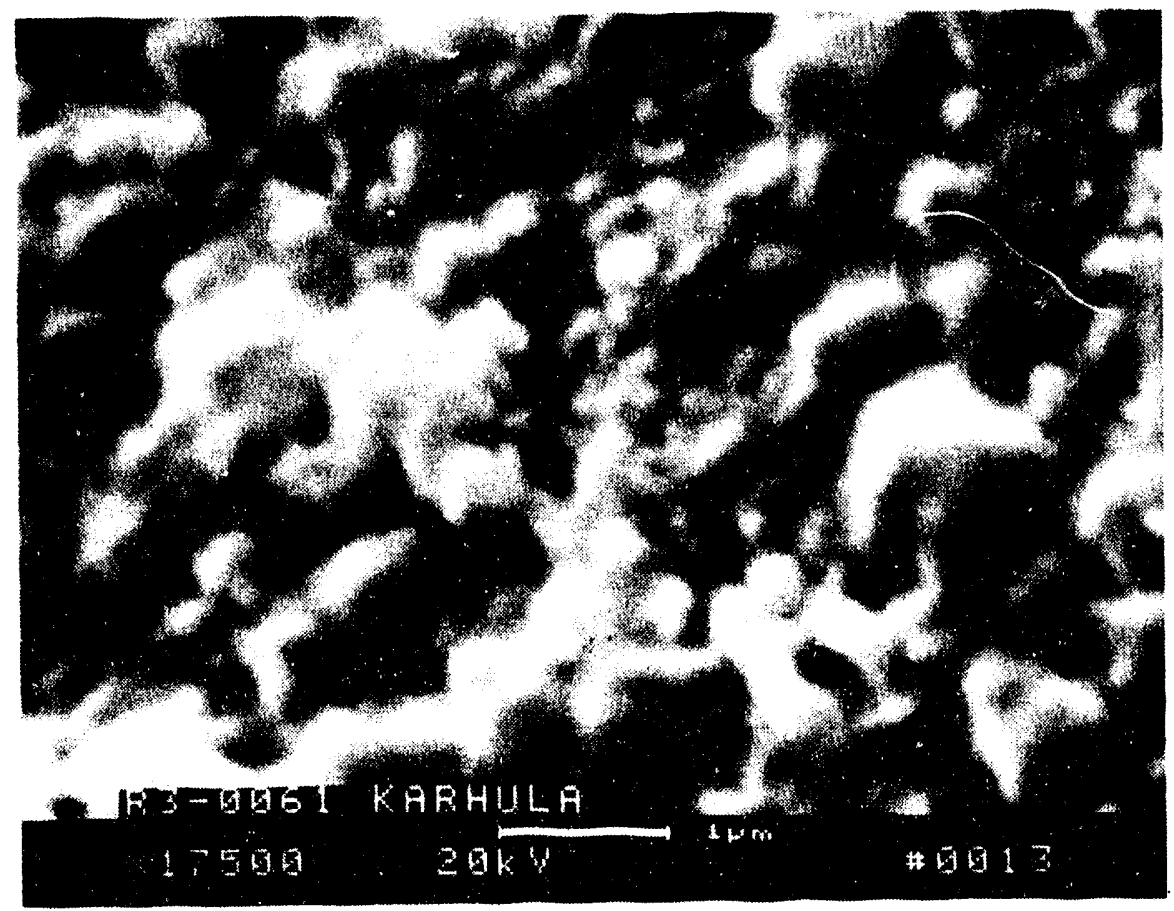

Figure 33c - Higher Magnification Micrograph Illustrating The Mottled Features Of The Binder Coating 
binder surface features, as well as the adherence of numerous 5-10 $\mu \mathrm{m}$ particles. EDAX analysis of Area 1, Photo 10, Figure 33a indicates the presence of $59.77 \% 0,29.11 \% \mathrm{Si}, 7.72 \% \mathrm{Al}, 1.55 \% \mathrm{Na}, 0.74 \% \mathrm{~K}, 0.57 \% \mathrm{Mg}$, and $0.55 \% \mathrm{Fe}$. The typical mottled surface features of the binder phase shown in Area 2, Photo 10, Figure 33a consists of $54.03 \% 0,38.76 \% \mathrm{Si}$, $5.65 \% \mathrm{Al}, 1.02 \% \mathrm{~K}, 0.52 \% \mathrm{Fe}$, and $0.23 \% \mathrm{Na}$. The raised agglomerate features shown in Area 3, Photo 10, Figure 33a consists of $57.21 \% 0$, $30.42 \% \mathrm{Si}, 6.26 \% \mathrm{Kg}, 3.47 \% \mathrm{Al}, 1.72 \% \mathrm{Fe}, 0.79 \% \mathrm{Ca}$, and $0.34 \% \mathrm{~K}$. Note the clcse similarity between the composition of the CFBC ash particulates and the binder phase. Area scan analysis of Area 1, Photo 12, Figure 33b indicates the presence of $58.74 \% 0,26.57 \% \mathrm{Si}, 10.90 \% \mathrm{Mg}$, $2.87 \% \mathrm{Al}, 0.81 \% \mathrm{Ca}, 0.66 \% \mathrm{Fe}, 0.42 \% \mathrm{~K}$, and $0.23 \%$ rare earth. The presence of the rare earth in this area of the matrix implies the binder phase of the CFBC-exposed Pall Vitropore 442T filter matrix, while the presence of magnesium and calcium indicates the inclusion of ash fines. The surface fentures of the binder coated silicon carbide grain shown in Photo 12, Figure 33b are expected to result from phase transformations along the binder surface in the CEBC-exposed Pall Vitropore 442T filters. Higher magnification of the binder surface morphology is shown in Photo 13, Figure 33c. The mottled surface consists of $53.63 \% 0$, $37.63 \% \mathrm{Si}, 6.63 \% \mathrm{Al}, 1.22 \% \mathrm{~K}, 0.77 \% \mathrm{Fe}$, and $0.13 \%$ rare earth.

Figure 34 provided a series of micrographs again near the OD surface of the CFBC-exposed Pall Vitropore 442T filter. Note the presence of what appears to be fine particulates adhering to the binder phase shown in Photo 14 and 15, Figure 34b, as well as the convoluted binder layer that formed near the surface of the silicon carbide grain. Area scan analysis of the smooth feature shown in Area 1, Photo 16, Figure 34c indicates the presence of $62.10 \% \mathrm{Si}, 30.45 \% 0,4.12 \% \mathrm{Al}$, $3.09 \% \mathrm{~K}$, and $0.24 \%$ rare earth. The somewhat mottled features shown in Area 2, Photo 16, Figure $34 \mathrm{c}$ contain $59.23 \% \mathrm{O}, 40.58 \% \mathrm{Si}$, and $0.19 \% \mathrm{Al}$. 


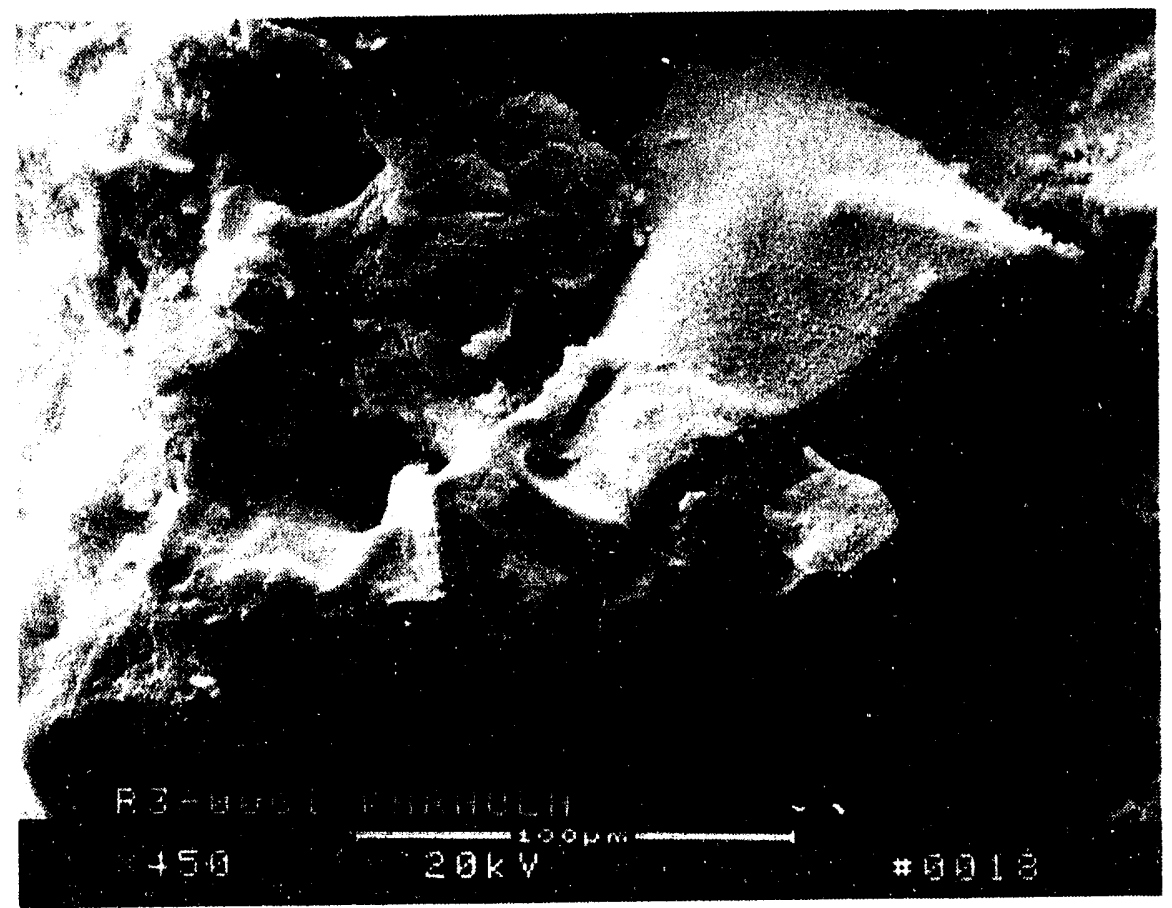

FIgure 34a - Yicrograph Illustrating The Morphology of The Clay Bonded Silicon Carbide Filter Matrix After Exposure To The CFBC Gas Bnvironment 

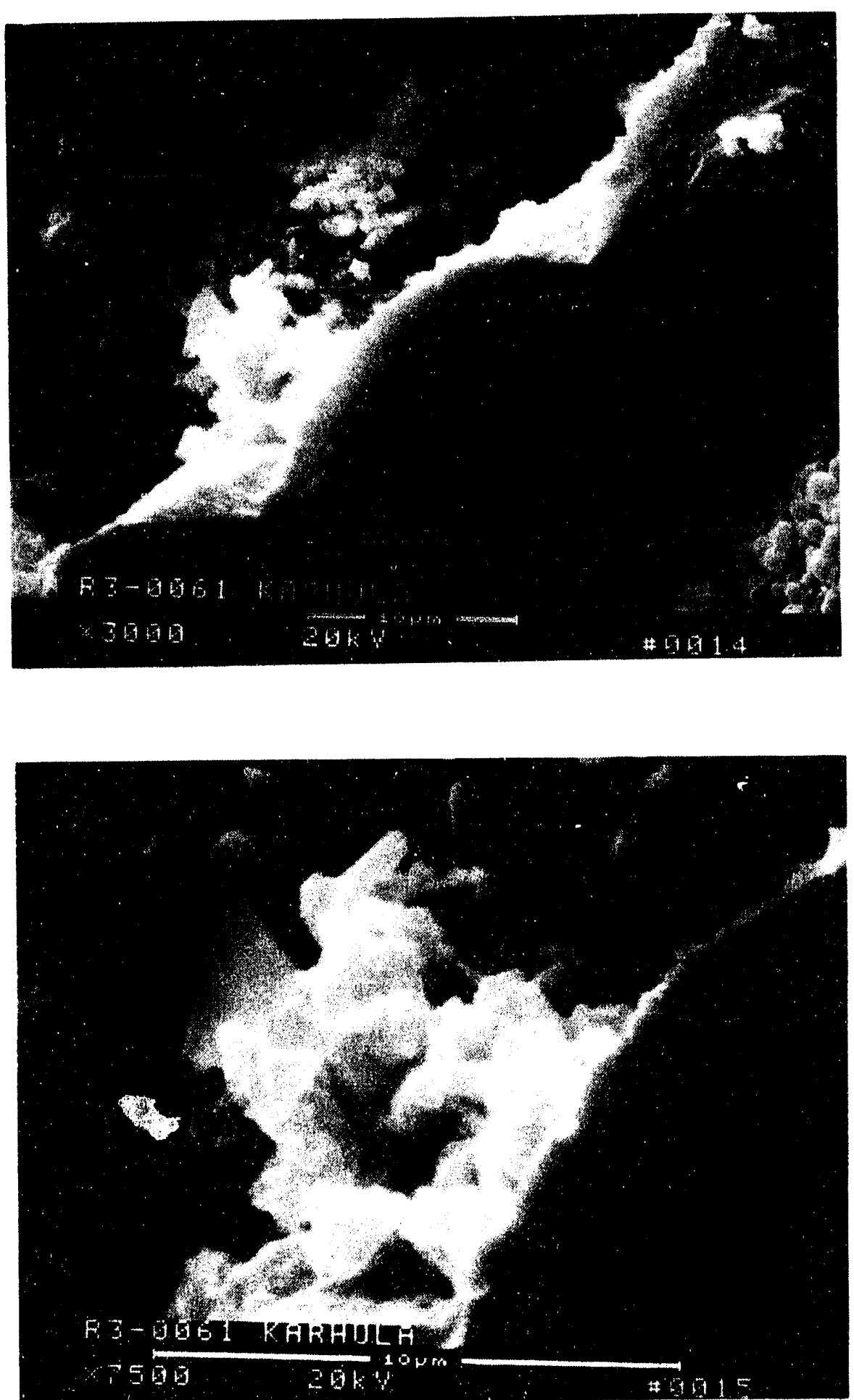

Figure 34b - Micrographs Illustrating The Binder And Adhering Fines Near The OD Menbrane Surface of The CFBC-Exposed Pall Vitropore 442T Candle Filter 

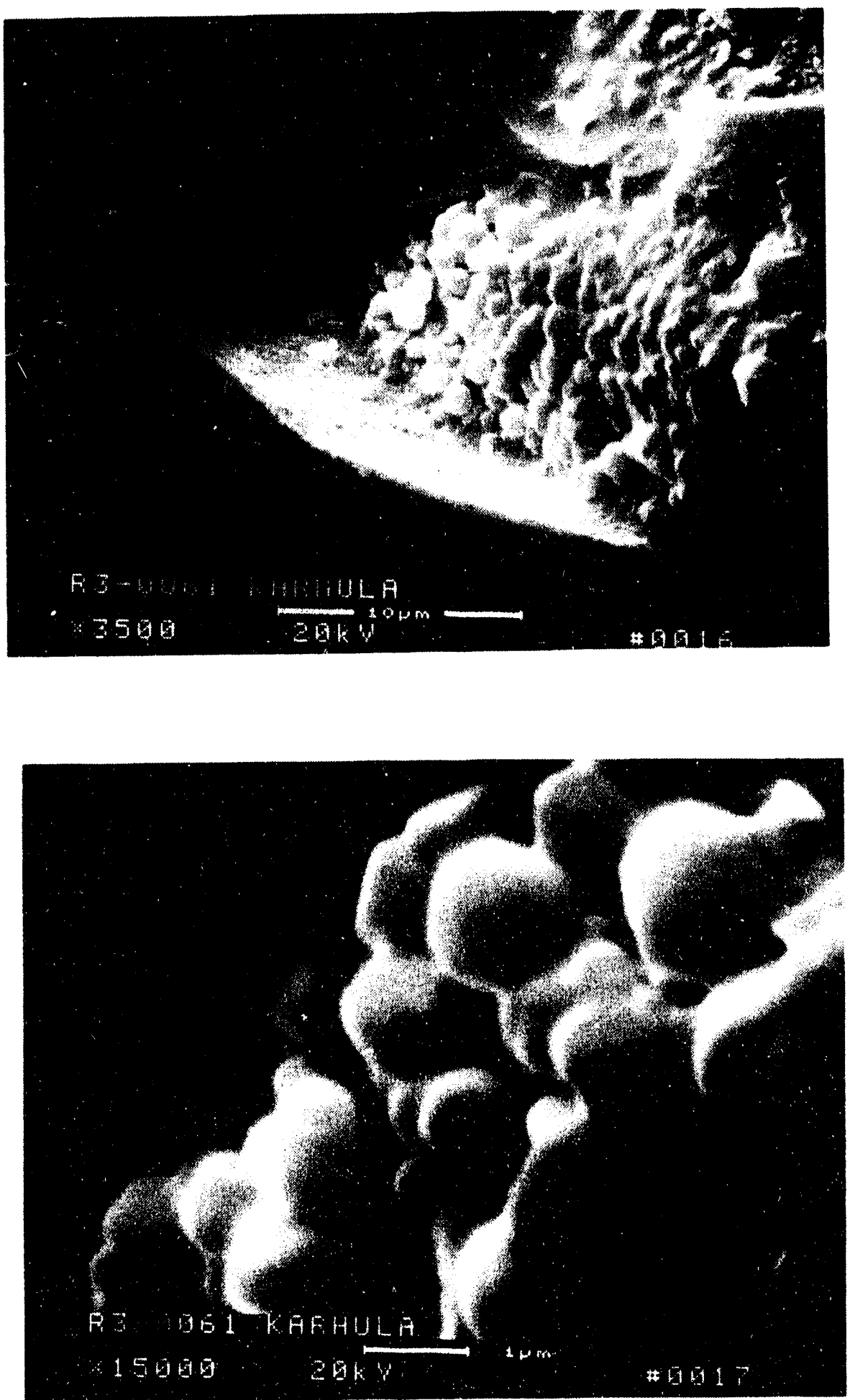

Figure 34c - Micrographs Illustrating The Morphology of The Binder Coating Surface Along Silicon Carbide Grains Near The OD Membrane Surface of The CPBC-Exposed Pall Vitropore 442T Candle Filter 
Similar features are evident along the binder phase which coats the silicon carbide grains that are located 3-4 grain layers below the OD membrane surface. EDAX analysis of Area 1, Photo 20, Figure 35 indicates the presence of $47.72 \% 0,43.18 \% \mathrm{Si}$, and $8.10 \% \mathrm{Al}$ in the surface of the binder phase. EDAX characterization of Area 2, Photo 20, Figure 35 indicates the presence of silicon and carbon, indicating the location of the silicon carbide grain.

Figure 36 shows the morphology of the fractured binder ligament between two adjacent silicon carbide grains which are 3-4 grain layers below the OD membrane surface. The composition of the binder ligament consists of $51.26 \% 0,36.29 \% \mathrm{Si}, 6.41 \% \mathrm{Al}, 3.30 \% \mathrm{Na}, 1.18 \% \mathrm{Fe}, 1.11 \% \mathrm{~K}$, and $0.45 \%$ rare earth (Area 1, Photo 22, Figure 36).

Similar mottled features along the binder surface are also detected at approximately $5 \mathrm{~mm}$ from the $O D$ surface, as well as $5 \mathrm{~mm}$ from ID surface of the CFBC-exposed Pall Vitropore $442 T$ candle filter matrix (Figure 37). Cracks and separations are readily evident in the binder coating. High magnification micrographs illustrating the morphology of the mottled binder surface features (Area 1, Photo 26, Figure 37b) are shown in Photo 27, Figure 37c.

$A$ mottled binder coating surface appearance results along silicon carbide grains that are located at approximately $2 \mathrm{~mm}$ from the ID surface of the $\mathrm{Pall}$ Vitropore $442 \mathrm{~T}$ filter (Figure 38). Areas are evident where the binder ligaments have been fractured during sampling. The binder ligament in these areas appears to be not only discontinuous, but also contains holes (Area 1, Photo 29, Figure 38a). Area 2, Photo 29, Figure $38 \mathrm{a}$ is shown at higher magnification in Photo 30, Figure 38b. The particle-like features (Area 1, Photo 30, Figure 38b) consists of $56.97 \% 0,25.21 \% \mathrm{Si}, 14.48 \% \mathrm{Al}, 1.91 \% \mathrm{Na}, 0.74 \% \mathrm{Fe}$, and $0.70 \% \mathrm{~K}$. The amorphous features of Area 2, Photo 30, Figure 38b consist of $56.55 \% 0$, $32.98 \% \mathrm{Si}, 6.89 \% \mathrm{\Lambda l}, 2.50 \% \mathrm{Na}, 0.61 \% \mathrm{~K}, 0.25 \% \mathrm{Ca}$, and $0.23 \%$ rare earth, indicating the presence of the binder phase. The presence of calcium in 

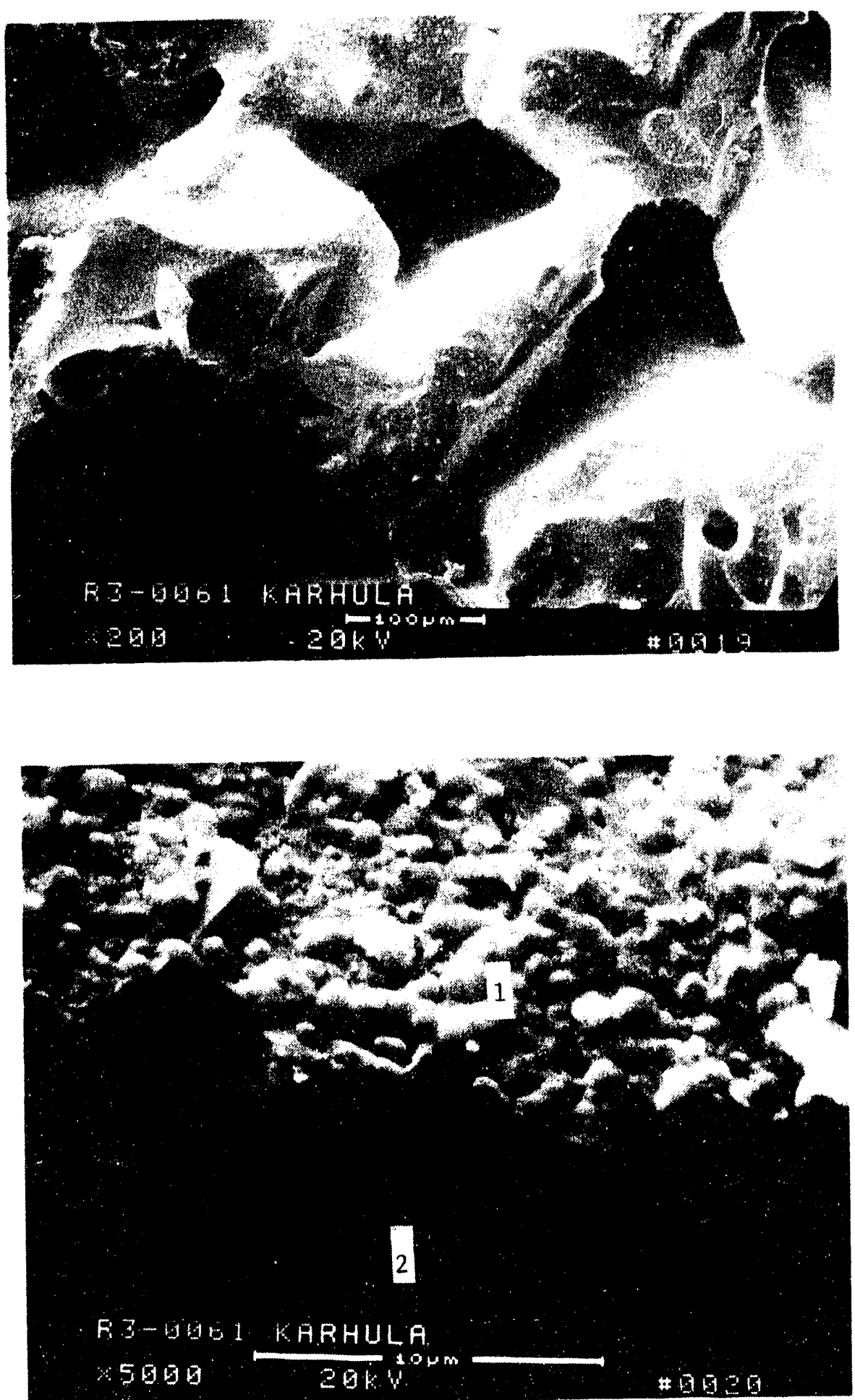

Figure 35 - Micrographs Illustrating The Morphology of The Binder Coated Silicon Carbide Grains Located At 3-4 Grain Layers Below The OD Membrane Surface of The CFBC-Bxposed Pall Vitropore 442T Candle Filter 

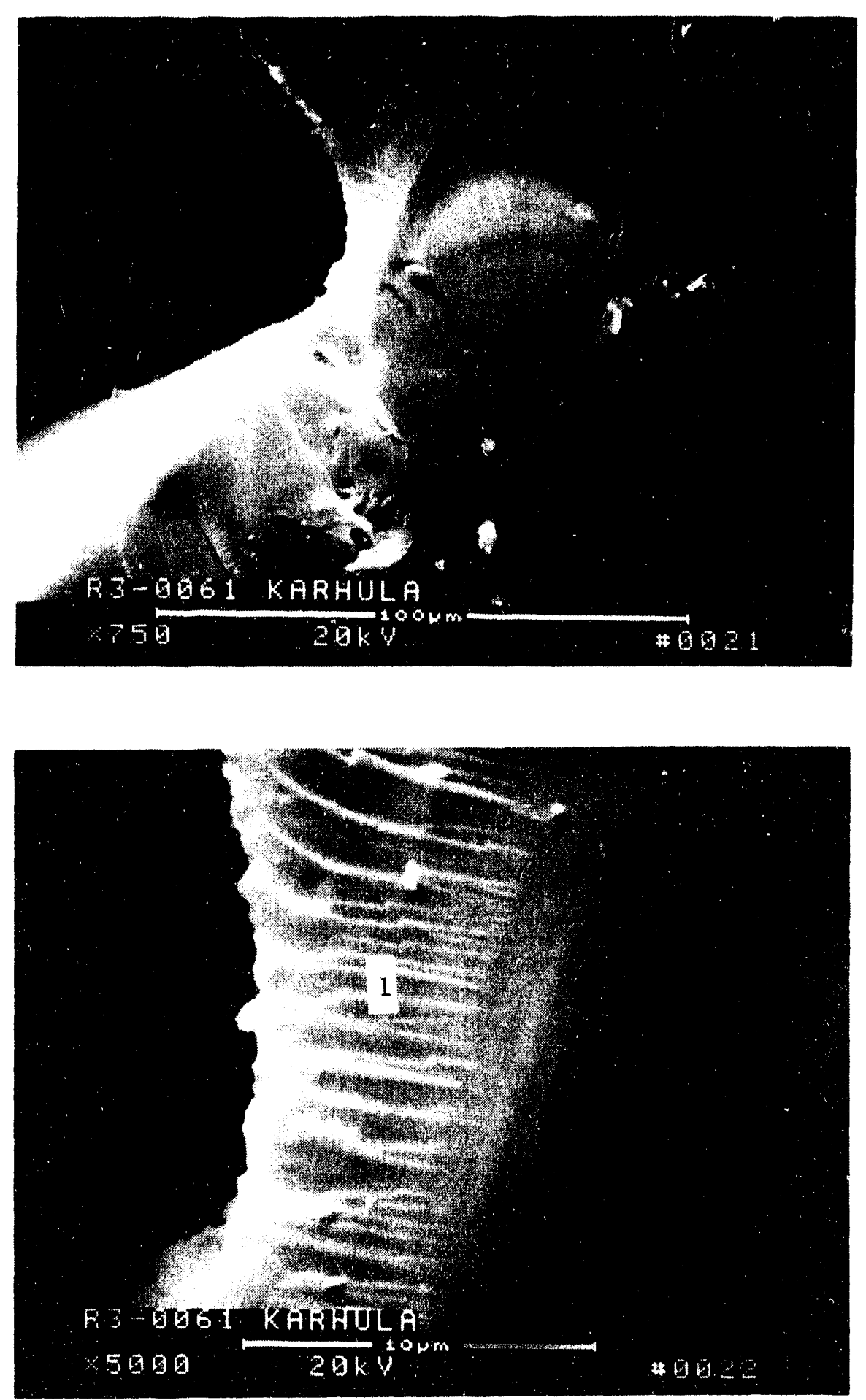

Figure 36 - Korphology Of A Binder Liganent Between Adjacent Grains That Are Located 3-4 Grain Layers Below The OD Membrane of The CFBC-Exposed Pall Vitropore 442T Candle Filter 

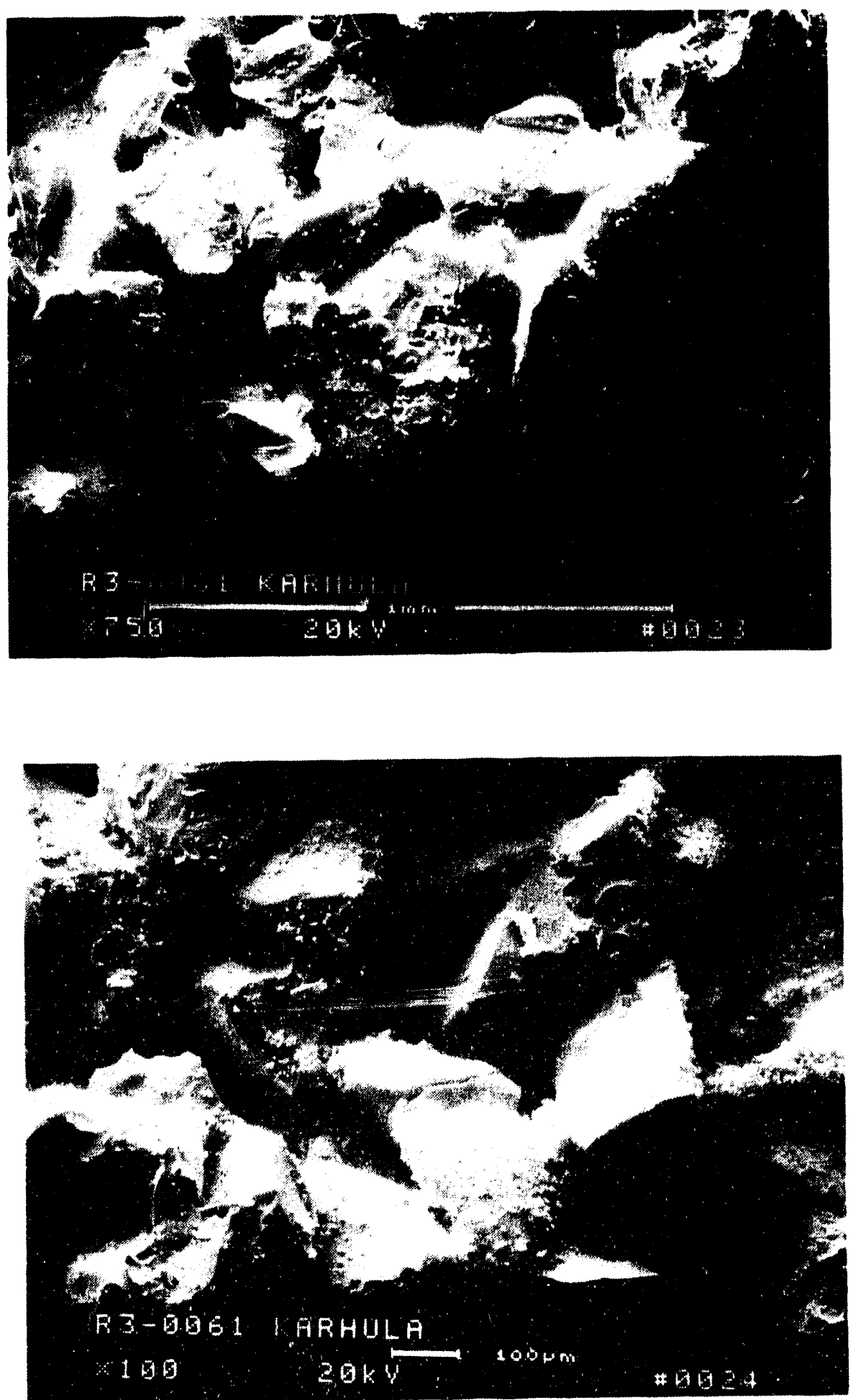

Figure 37a - Nicrographs Illustrating The Norphology Of The CFBCExposed Pall Vitropore 442T Yatrix At Approximately $5 \mathrm{~mm}$ Below The OD Membrane of The Candle Filter 

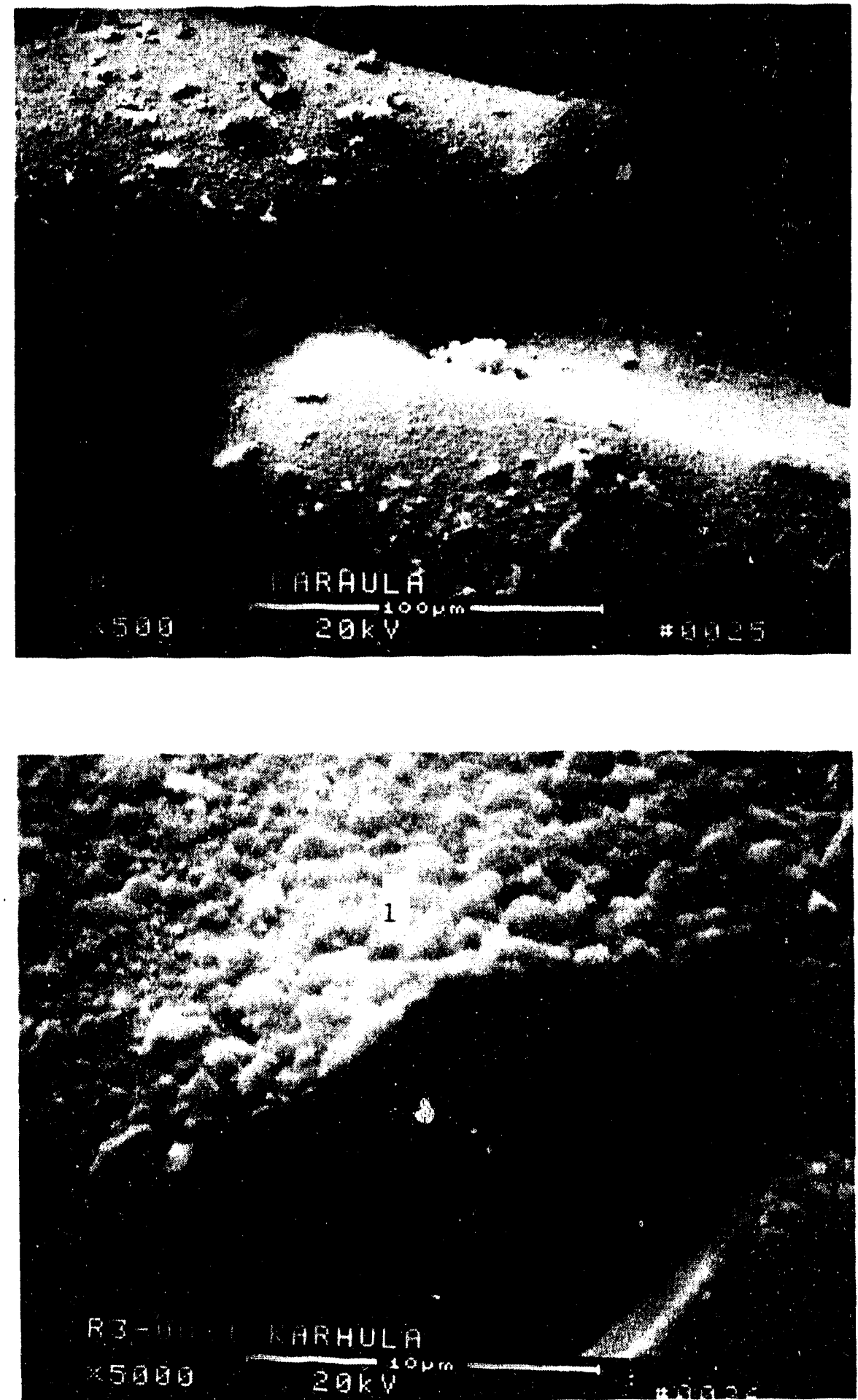

Figure 37b - Higher Magnification Micrographs Illustrating The Extensive Yottling And Crack Formations which Result In The Binder. Coating Along Grains That Were Located $5 \mathrm{~mm}$ Belor The OD Membrane of The CFBC-Exposed Pall Vitropore 442T Candle Pilter 


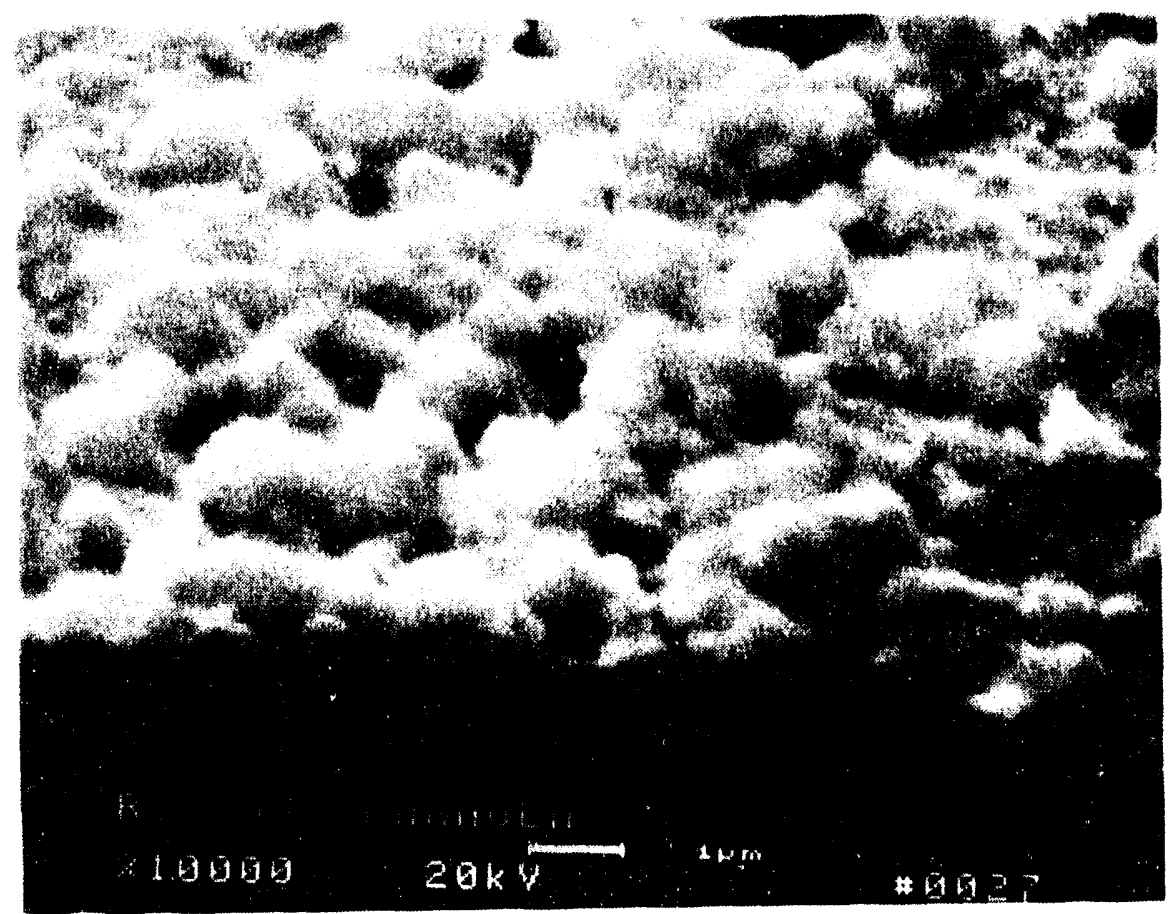

Figure 37c - Higher Magnification Micrograph Illustrating The Morphology of The Mottled Binder Phase 

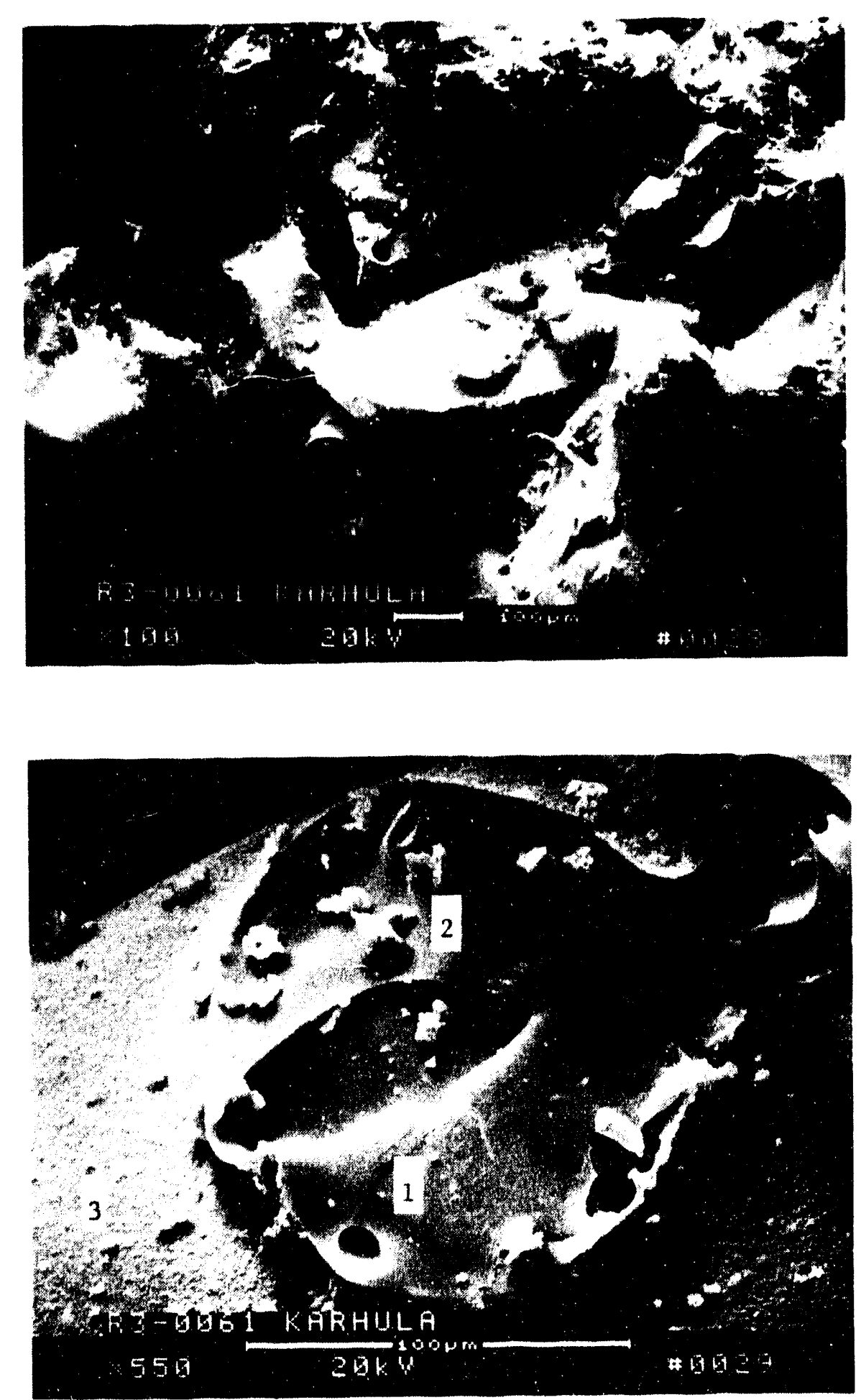

Figure 38a - Norphology Of The CrBC-Exposed Pall Vitropore 442T Filter At Approximately 2 an Pron The Pilter ID Surface 


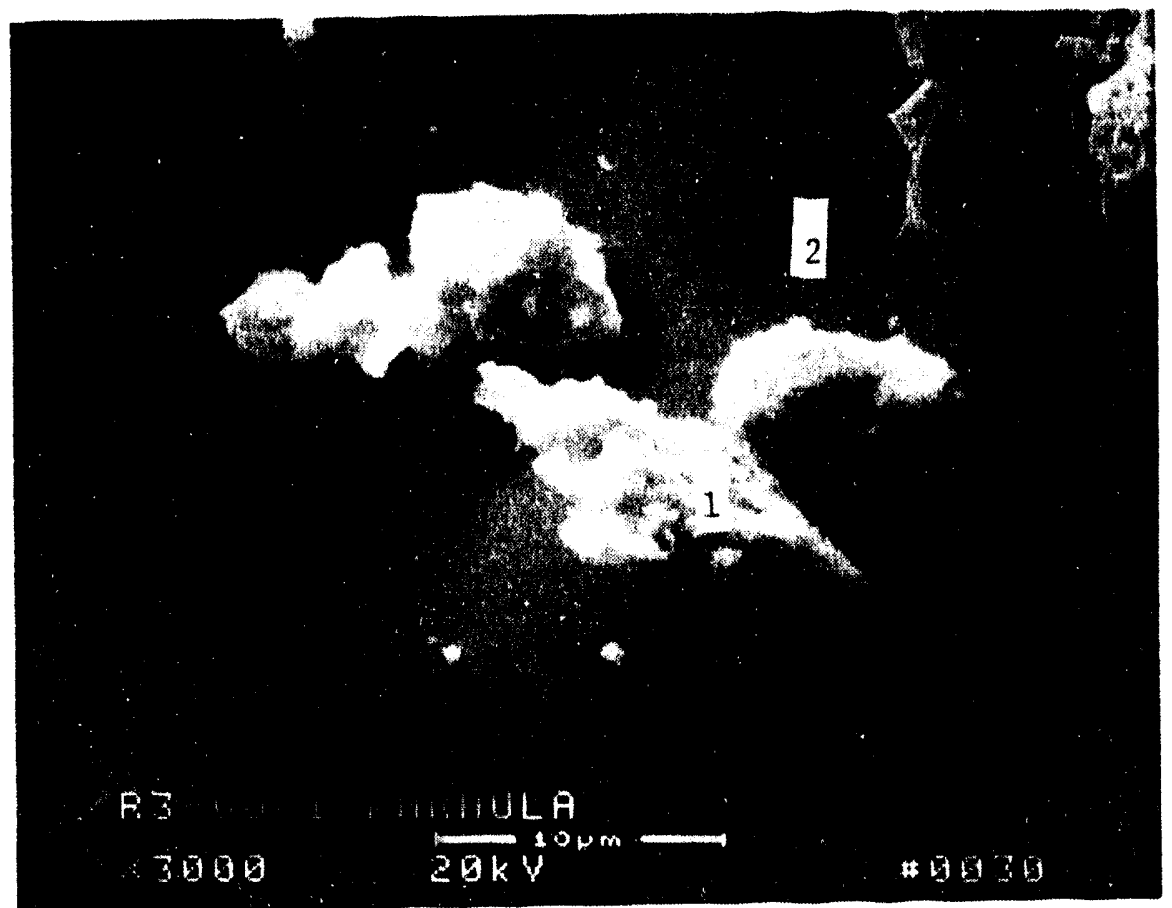

Figure 38b - Adherence Of Fines Along The Binder Ligament 


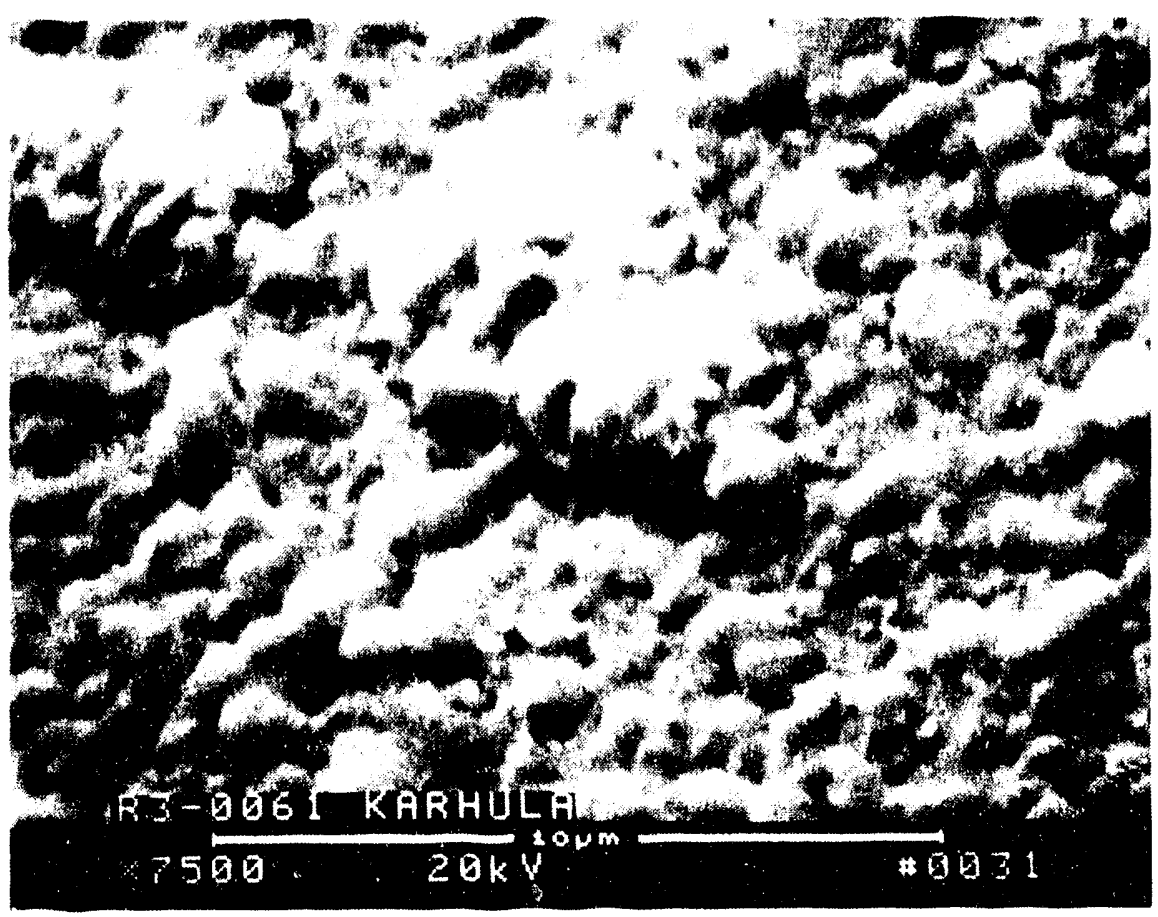

Figure 38c - High Magnification Micrograph Illustrating The Mottled Surface Features of The Binder Costing Along Silicon Carbide Grains That Are Located At Approximately $2 \mathrm{~mm}$ From The Pilter ID Surface 
this area is considered to be an artifact of the rdjacent adhering fine particle. The mottled binder surface features shown in Area 3, Photo 29, Figure 38a are shown at higher magnification in Photo 31, Figure 38c. The composition of the mottled binder surface includes $60.22 \% \mathrm{O}, 31.76 \% \mathrm{Si}, 5.33 \% \mathrm{~A} 1,1.41 \% \mathrm{Na}, 0.75 \% \mathrm{Fe}, 0.38 \% \mathrm{~K}$, and $0.16 \%$ rare earth

Fines are seen to have penetrated the ID surface of the Pall Vitropore 442T filter after failure of the ten alumina/mullite candle filters in the Westinghouse Advanced Particulate Filtration system. The ash fines are shown to adhere to the binder coated silicon carbide grains in Figure 39. The composition of the fines (Photo 33, Figure 39) includes $58.66 \% \mathrm{0}, 22.32 \% \mathrm{Si}, 15.02 \% \mathrm{Al}, 1.74 \% \mathrm{Fe}, 1.41 \% \mathrm{Ca}, 0.54 \% \mathrm{Ti}$, and $0.30 \% \mathrm{~K}$.

Figure 40 provides another series of micrographs alozg the ID surface of the CFBC-exposed Pall Vitropore 442T filter. Heavy accumulation of fines is evident in the pore channels in this area of the filter. Area scan analyses of the fines shown in Area 1, Photo 35, Figure 40a indicates the presence of $63.26 \% 0,22.26 \% \mathrm{Si}, 10.57 \% \mathrm{Al}$, 1.74\% $\mathrm{Fe}, 1.43 \% \mathrm{Ca}$, and $0.73 \% \mathrm{Ti}$. Photo 36, Figure 40b illustrates the binder/grain interface along the ID surface silicon carbide grains. The mottled features of the binder phase are evident amidst the adhering particulate fines.

Gravimetric Leaching And Qualitative X-Ray Diffraction Analysis

Samples from both the as-manufactured and field-tested Schumacher Dia Schumalith F40 and Pall Vitropore $442 T$ candlo filters were ultrasonically leached with water and then ground in a tungsten carbide ball mill. The samples were weighed into platinum dishes and HF was added. The samples were then taken to dryness, and re-weighed. The resulting weight loss is considered to reflect the concentration of $\mathrm{SiO}_{2}$ present in each material. 

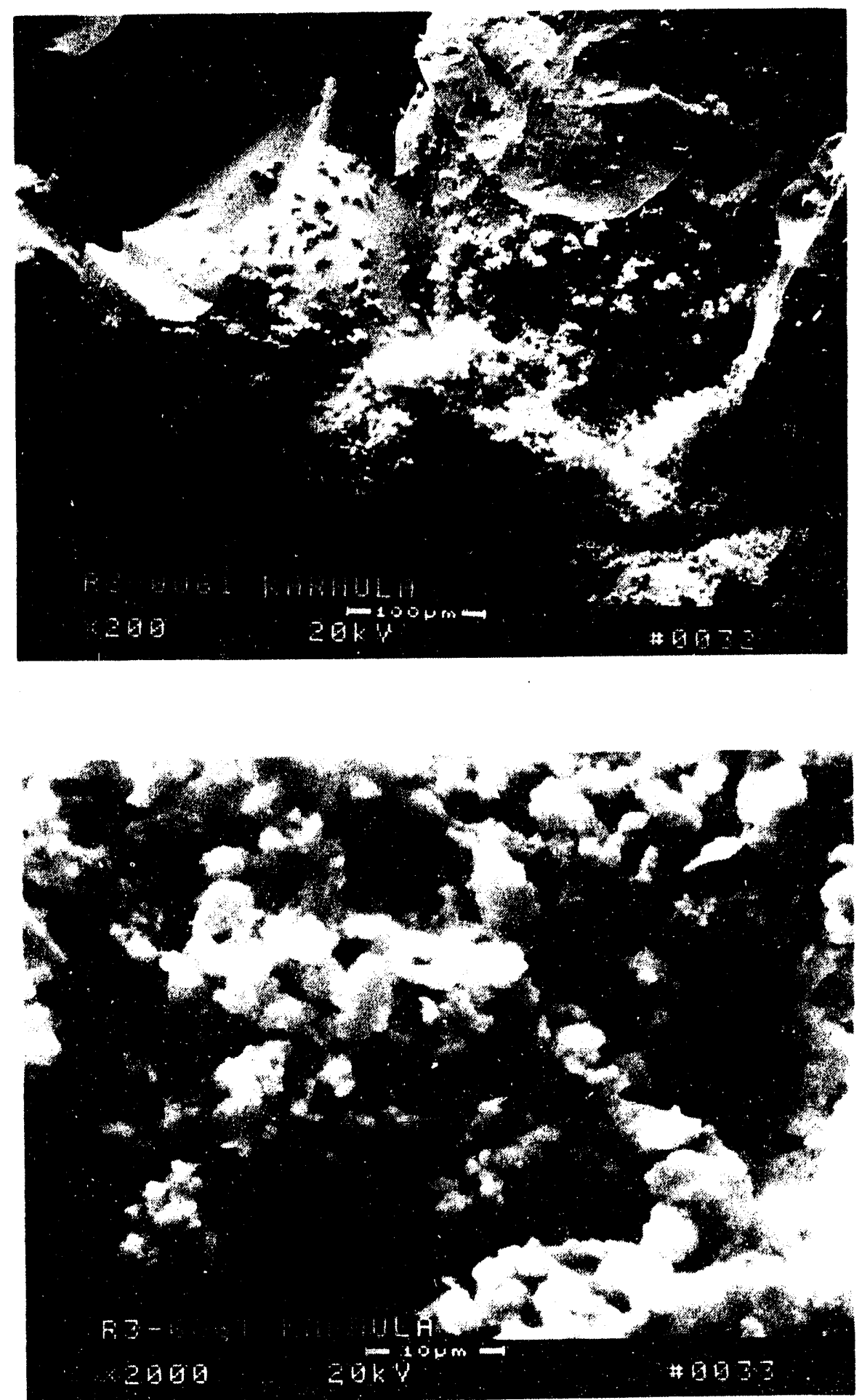

Pigure 39 - Micrographs Illustrating The Adherence Of Fines Along The ID Surface of The CFBC-Exposed Pall Vitropore 442T Candle Pilter 

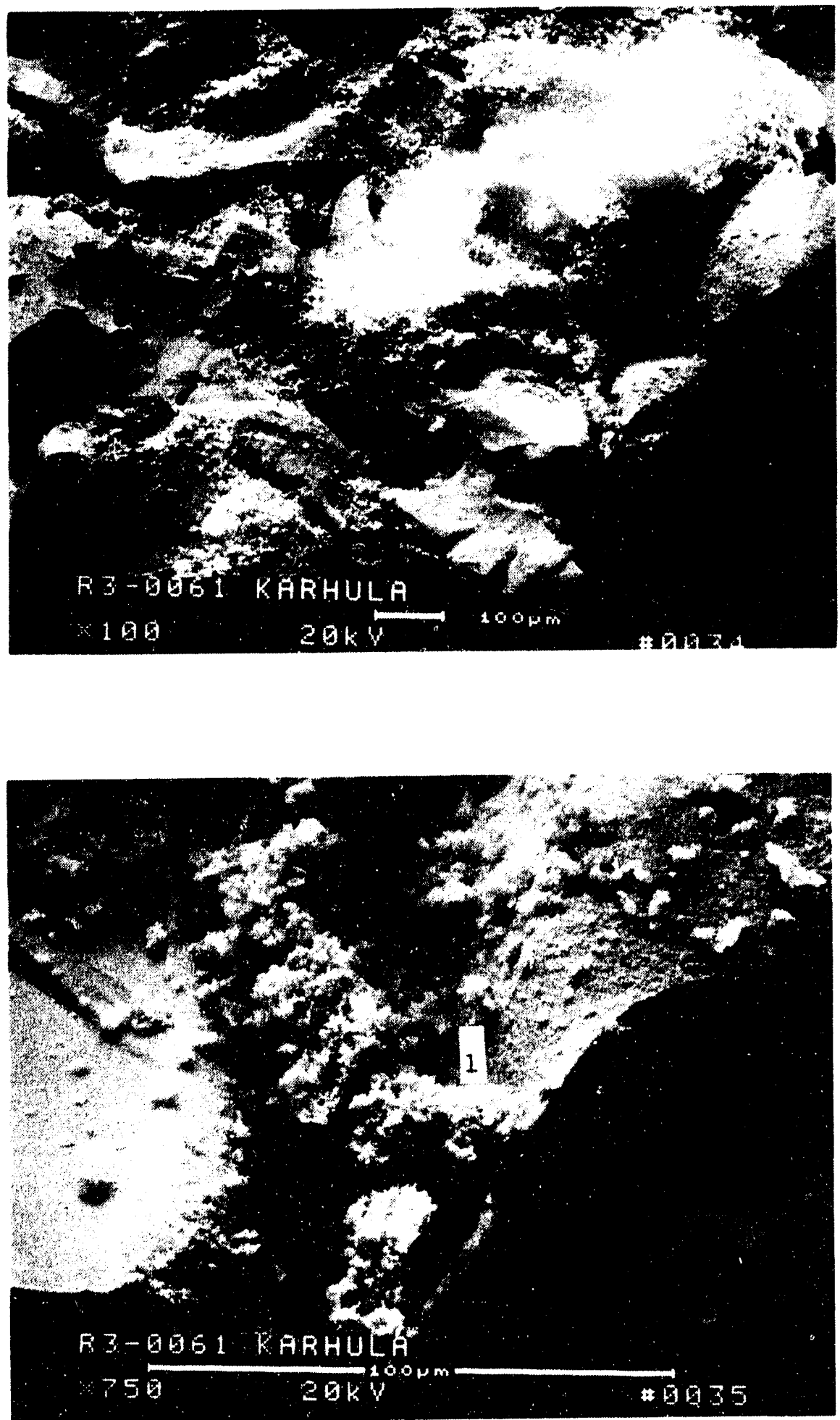

Figure 40a - Micrographs Illustrating The Adherence Of Fines Along An Alternate Location of The ID Surface of The CFBC-Exposed Pall Vitropore 442T Candle Filter 


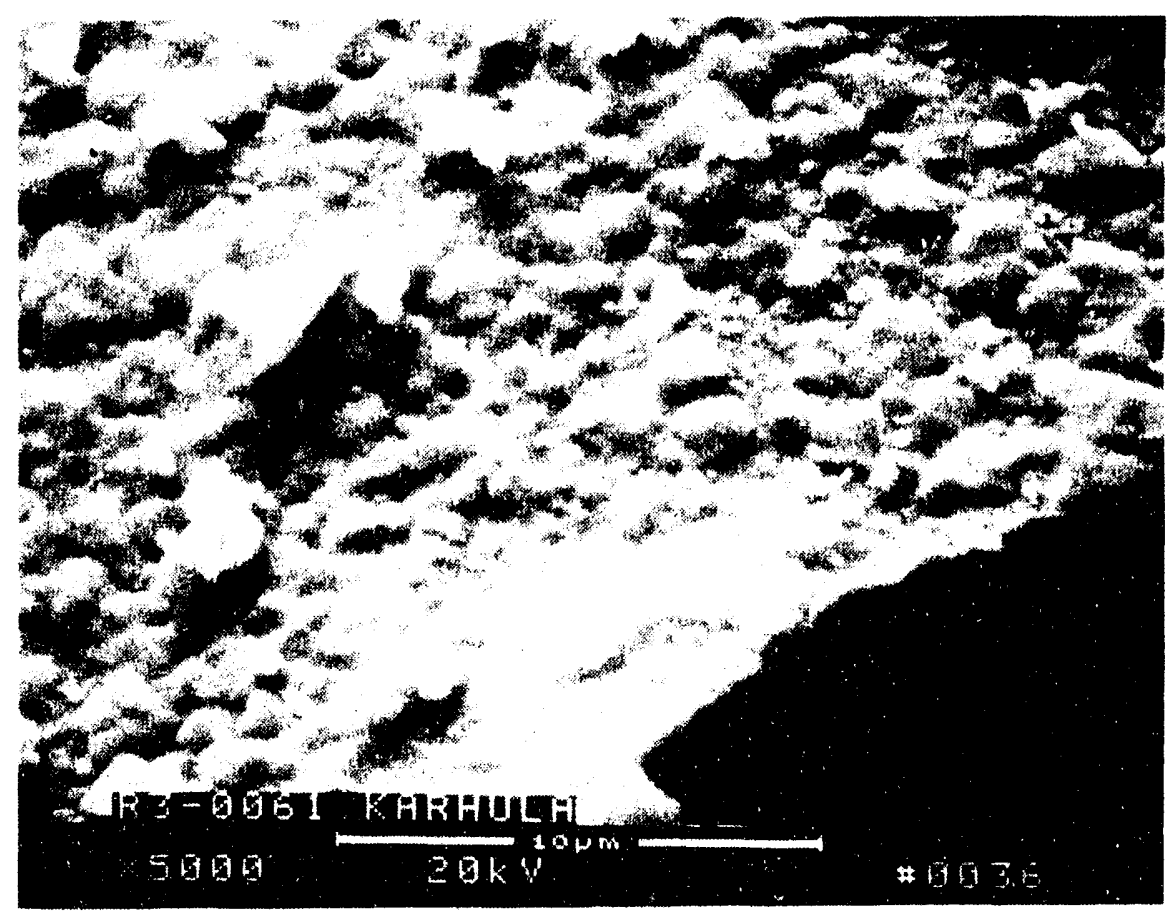

Figure 40b - High Yagnification Micrograph Illustrating The Mottled Surface Peatures of The Binder Phase Which Coats The ID Surface Silicon Carbide Filter Grains 
As showr in Table 4, the $\mathrm{SiO}_{2}$ concentration for both the Schumacher Dia Schumalith F40 and Pall Vitropore 442T matrices is approximately 6-8\%. XRD analyses are also provided in Table 4 for the coarse and fine fractions of the CFBC-exposed Schumacher Dia Schumalith F4O and Pall Vitropore $442 T$ matrices, as well as the as-manufactured Pall Vitropore $442 T$ matrix. The fine fraction is dominated by the oxide phase since it is easier to crush than the coarser silicon carbide grains. Mullite, if present in the oxide phase, is not expected to dissolve completely in the HF solution, and therefore a lower resulting $\mathrm{SiO}_{2}$ concentration will be estimated via the BF dissolution technique. The presence of mullite as a result of crystallization of the Schumacher Dia Schumalith F40 binder at CFBC temperatures may be responsible for the lowered $\mathrm{SiO}_{2}$ content in comparison to the as-manufactured Schumacher Dia Schumalith F40 matrix.

In the as-manufactured Schumacher Dia Schumalith F40 matrix, 4H and $6 \mathrm{H}$ polytypes of silicon carbide are present, as well as cristobalite and mullite. Similar $x$-ray diffraction patterns are evident in the Schumacher Dia Schumalith F40 matrix after 227 hours of exposure to the CFBC gas environment. Note the presence of a trace concentration of tridymite in the crushed oxide fines in the CFBC-exposed Schumacher Dia Schumalith F40 matrix. At this time tridymite is considered to primarily result from the reaction of the as-manufactured binder sodium concentration with silica, as opposed to sorption and reaction of gas phase sodium with the binder matrix. If the concentration of tridymite increases with increased exposure time, we would then conclude that the binder is sorbing gas phase sodium that is released into the effluent CFBC gases.

The Pall Vitropore 442T matrix similarly consists of polytypes of a-silicon carbide, with mullite and a trace of tridymite present in the coarse fraction of the material. Cristobalite is evident in this fraction after the Pall Vitropore 442T matrix is exposed for 227 hours 
TABLE 4

GRAVINETRIC LEACHING AND QUALITATIVE XRD ANALYSIS OF AS-MANUFACTURED AND CFBC-EXXPOSED SIIICON CARBIDE CANDLE FILTERS
Matrix
$\mathrm{XSiO}_{2} *$
XRD Analysis

Schumacher Dia Schumalith F40

As-Yanufactured $\quad \mathbf{8 . 0 6}$

$4 \mathrm{H}$ and $6 \mathrm{H}$ polytypes of SiC. Evidence of cristobalite and mullite.

$\mathrm{S} 2855 / 374 \mathrm{C} * * \quad 6.16$

Hex polytypes of a-SiC, cristobalite, (T12) and mullite.

Fines: Yore cristobalite than mullite. Trace of tridymite.

Pall Vitropore $442 T$

As-Manufactured

6.79

Hex a-SiC, mullite, trace of tridymite. Fines: Glass plus trace of cristobalite. Yore oxide than the CFBC-exposed Schumacher Dia Schumalith F40 matrix.

R3-0061**

7.57

Hex a-SiC, mullite and cristobalite, (M18) trace of tridymite. Fines: Mullite, cristobalite and tridymite. Yore oxide than the asmanufactured Pall or CFBC-exposed Schumacher matrix.

* Gravimetric Leaching.

** CFBC-Exposed Materials. 
to the CFBC gas environment. Notably in the fine fraction of th $\mathrm{Pall}$ Vitropore 442T matrix, glass plus a trace of cristobalite are present in the as-manufactured matrix, while mullite, cristobalite and tridymite are identified after 227 hours of CFBC operation. The quantity of oxide present is increased in the CFBC-exposed Pall Vitropore 442T matrix over its original background content, implying that oxidation of the matrix may have occurred.

Conclusions

- Both the Schumacher Dia Schumalith F40 and Pall Vitropore 442T clay bonded silicon carbide candle filters lose room temperature and process temperature $\left(900^{\circ} \mathrm{C}\right)$ strength after 227 hours of operation in the CFBC gas environment.

- Although the Pall Vitropore 442T filter is initially stronger than the Schumacher Dia Schumalith F40 filter, the resulting CFBC-exposed hot strength along the Schumacher ID surface is $2392 \mathrm{psi}$, while the $\mathrm{Pall}$ ID surface is 2014 psi. In contrast the CFBC-exposed Schumacher OD surface hot strength is only $987 \mathrm{psi}$, while the Pall OD hot strength is 2203 psi.

- A greater percentage of strength is lost along the ID surface of the Pall Vitropore 442T candle filters after 227 hours of operation in the CFBC gas environment, implying that the matrix has experienced thermal fatigue during pulse gas cleaning.

- A greater percentage of strength is lost along the OD surface of the Schumacher Dia Schumalith F40 candle filters after 227 hours of operation in the CFBC gas environment, implying that the matrix has experienced thermal (and/or) chemical degradation during hot gas filtration. Note that the Schumacher Dia Schumalith F40 matrix appears to be somewhat more resistant to thermal fatigue along its ID surface in comparison to the Pall Vitropore $442 T$ matrix. 
- The OD membrane of the Schumacher Dia Schumalith F40 matrix remains intact after 227 hours of operation in the CFBC gas environment. Fines are not observed to have penetrated through the fibrous aluminosilicate membrane. In contrast, fines are evident within the support grains of the Pall Vitropore 442T matrix. The adhering fines are attached to the binder coated grains along the OD surface and mid-section of the Pall Vitropore $442 T$ filter. The fines do not fill and/or plug the pore channels.

- Although all twenty-one of the clay bonded silicon carbide candle filters remained intact during the 227 hours of operation in the CFBC gas environment, fines were detected to penetrate the ID surfaces of both the Schumacher and Pall filters. These fines were introduced via pulse cleaning after failure of ten alumina/mullite candle filters had occurred. The depth of fines penetration along the ID surface is nearly equivalent $(2-2.5 \mathrm{~mm})$ in both filter materials, irrespective of the wall thickness and pore channel dimensions.

- The binder surface in both the Schumacher Dia Schumalith F40 and Pall Vitropore 442T filters undergoes phase transformations during exposure to the CFBC gas environment. These appear to be surface effects which do not propagate through the binder coating or ligament thickness. The expected phase transformation is the formation of cristobalite. The resulting phase transformations within the clay binder of both the Schumacher and Pall filters may be responsible for the loss of material strength at process operating conditions.

- Changes within Schumacher Dia Schumalith F40 matrix include:

- Surface phase transformations. Coalescence of the silicarich areas (lower alumina content), leading to a separation and/or depletion of the surrounding binder matrix. 
- Formation of holes and microcracks in the binder coating.

- Formation of raised or blister areas in the binder coating.

- Evidence of outgassing of subsurface layers.

- Debonding of the binder phase, revealing what may be a thin cristobalite layer along the silicon carbide grain surface.

- Changes within the Pall Vitropore 442T matrix include:

- Binder surface phase transformations.

- Microcracks and separation within the binder surface which encapsulates the silicon carbide grains.

- Separation of the binder coating from the underlying silicon carbide grain.

- The rare earth additive which is included in the Pall Vitropore 442T matrix appears to diffuse to the binder coating surface during hot gas filtration in the CFBC gas environment. 

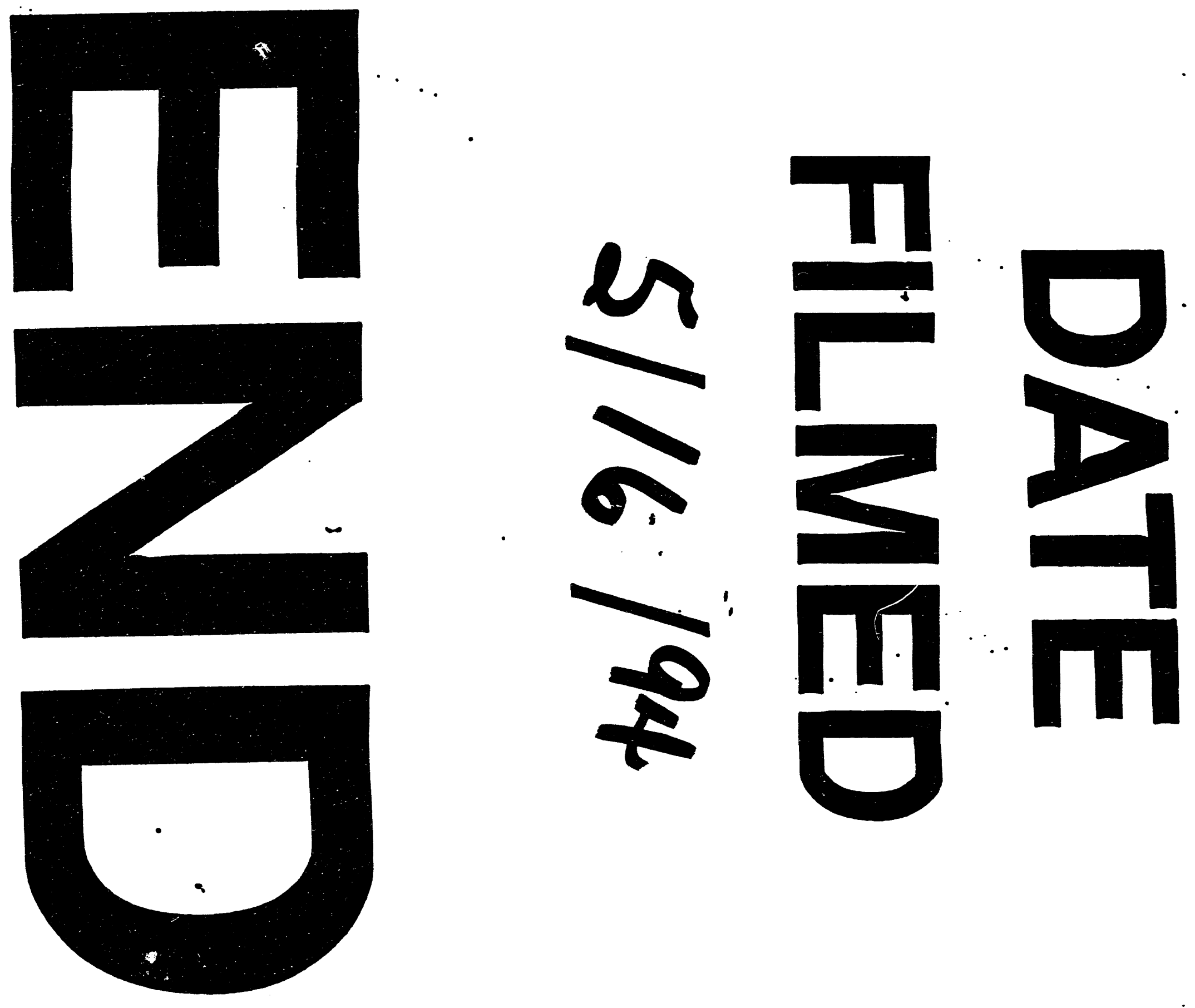
